CAROLINA PARGA MARTINS PEREIRA

\title{
O PAPEL DA MICROGLIA NO MODELO DE DOENÇA DE PARKINSON INDUZIDO POR 6-HIDROXIDOPAMINA
}

Tese apresentada ao Programa de Pós-Graduação em Fisiologia Humana do Instituto de Ciências Biomédicas da Universidade de São Paulo, para obtenção do Título de Doutor em Ciências.

São Paulo 
CAROLINA PARGA MARTINS PEREIRA

\section{O PAPEL DA MICROGLIA NO MODELO DA DOENÇA DE PARKINSON INDUZIDO POR 6-HIDROXIDOPAMINA}

Tese apresentada ao Programa de Pós-Graduação em Fisiologia Humana do Instituto de Ciências Biomédicas da Universidade de São Paulo, para obtenção do Título de Doutor em Ciências.

Área de concentração: Fisiologia Humana

Orientador: Prof. Dr. Luiz Roberto Giorgetti de Britto Co-orientadora: Prof. Dra. Nadja C. de Souza Pinto Versão Original

São Paulo 2019 
CATALOGAÇÃO NA PUBLICAÇÃO (CIP)

Serviço de Biblioteca e informação Biomédica

do Instituto de Ciências Biomédicas da Universidade de São Paulo

Ficha Catalográfica elaborada pelo(a) autor(a)

Parga Martina Pereira, Carolina

O PAPEL DA NICROGLIA NO NODELO DR DOENCA DR PARKINSON INDUZIDO POR 6-HIDROXIDOPAMINA / Carolina Parga Nartina Pereira; orientador Luiz Roberto Giorgetti de Britto; coorientador Nadja Criethina de Souza Pinto.-- São Paulo, 2019.

$156 \mathrm{P}$.

Tene (Doutorado)) -- Univeraidade de Săo Paulo, Inatituto de Ciencian Biomédicas.

1. Doença de Parkinaon - 2. microglia. 3. 6hidroxidopumina. 4. NADPH oxidase. I. Roberto Luiz orientador. II de Souza Pinto, Nadja Cristhina, coorientador. III. Titulo. 


\section{UNIVERSIDADE DE SÃO PAULO INSTITUTO DE CIÊNCIAS BIOMÉDICAS}

Candidato: Carolina Parga Martins Pereira

Título da Tese: O papel da microglia no modelo da doença de Parkinson induzido por 6-hidroxidopamina

Orientador: Dr. Luiz Roberto Giorgetti de Britto

A Comissão Julgadora dos trabalhos de Defesa da Dissertação de Mestrado/Tese de Doutorado, em sessão pública realizada a ............................, considerou o candidato:

\section{( ) Aprovado ( ) Reprovado}

Examinador(a): Assinatura:

Nome:

Instituição:

Examinador(a): Assinatura:

Nome:

Instituição:

Examinador(a): Assinatura:

Nome:

Instituição:

Presidente: Assinatura:

Nome:

Instituição: 
UNIVERSIDADE OE SAOO PAULO

INSTITUTO DE CIENCLIAS BIOMEDICAS

COMSSAO DE ETICA NO USO OE ANIMAIS

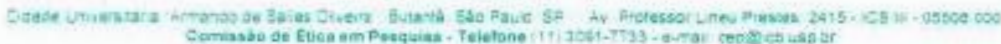

ICBUSP

Certificado

Certificamos que a solicitação de ficença de uso de animais intitulada "Fenótipos microgliais e a doença de Parkinson", registrada sob $n^{2} \quad 72$, nas fls. 34 , do livro 3 , foi analisada e aprovada pela COMISSÃO DE ETICA NO USO DE ANIMAIS (CEUA-ICB/USP) em 17/07/2015.

Por esta licença, estầo autorizados a manipular animais dentro dos limites do projeto proposto e no ambito da Lei Federal n 11.794 , o Dr.(Dra.) Luiz Roberto Giorgetti de Britto (Investigador Principal) e os membros da equipe: Caralina Pargo Martios Pereira. Esta licença de uso de animais expira em 17/07/2019.

Havendo interesse na renozação da proposta, a solicitaçato deverá ser protocolada pela secretaria da CEUAICB/USP até o ütimo dia de validade da atual proposta. Após essa data, uma nova proposta deverá ser encaminhada.

Certificate

We hereby certify that permission for the use of animals was granted to the research proposal "Microglial phenotypes and Parkinson's disease", registered as Number 72, in pages 34, of book 3, by the local ETHICS COMMITTEE ON THE USE OF ANIMALS (CEUA-ICB/USP) in 7/17/2015.

Under this license, Luiz Roberto Giorgetti de Britto (Principal Investigator) and team members Carolina Parga Martins Pereina are authorized to make use of animals within the limits of the research proposal presented to this committee and of the Brazilian Federal Law n 11.794.

This license expires in 7/17/2019. In case the investigators wish to renew this license, this must be presented to CEUA-ICB/USP before the last day of validity of the present license. After such date, a new research proposal must be presented.

Sàn Pauln, 27 de julho de 2015.

Buns

Prof. Dr. Anderson de Sá Nunes Coordenador CEUA-ICBJUSP
Eliane Gomer

Eliane Aparecida G, M. N. gomento Secretária CEUA-ICB/USP 


\section{AGRADECIMENTOS}

Ao Professor Dr. Luiz Roberto G. De Britto, por todo o apoio, discussões e auxílio na execução desse trabalho. Agradeço também por acreditar no meu trabalho e por sempre estar disposto a me ajudar.

À Professora Dra. Nadja C. de Souza Pinto, por toda a ajuda na execução do trabalho, pelo apoio, companherismo, pelas discussões enriquecedoras e por acreditar no meu potencial.

Ao Professor Dr. Kim Green, por me receber de Graços abertos no seu laboratório durante o período do BEPE realizado na Universidade da California em Irvine, me auxiliando em todos os processos da execução do meu trabalho e por sempre encontrar tempo para discutir a fundo os resultados. Agradeço também aos membros do seu laboratório, principalmente a Edna, Lindsay Hohsfield, Joshua, Miguel Arreola e Elizabeth Spangenberg, por me ajudarem sempre que precisei, por me receberem de forma harmoniosa, por serem gentis e amigos durante a minha estadia nos $\mathcal{E} \mathcal{A}$.

À Professora Dra. Andréa Torrão, pelo suporte na execução dos experimentos de PCR em tempo real, pelas conversas científicas, pelos conselhos e pela amizade.

Aos colegas de laboratório do ICB, por toda ajuda nos momentos dificeis, pelas discussões científicas, pelos momentos de alegrias compartilhados no ambiente laboratorial. Gostaria de agradecer especialmente aos amigos: Luciana Medina, por me ajudar nas discussóes científicas e pelo apoio; Monique Singulani, por ser meu ponto de apoio sempre que precisei, pelas conversas tranquilizadoras, por sempre estar por perto e disposta a ajudar; Priscila Crespo Garcia, por me auxiliar na execução de alguns experimentos, pelos conselhos, por ser essa amiga de todas as horas; José Francis de Oliveira por me ajudar nas análises estatísticas, pelas conversas cientificas enriquecedoras e pela amizade; Katherine Ravelli, Fernanda Crunfli e Andressa Costa pelo companherismo e amizade.

Aos colegas de laboratório do IQ, por todos os momentos alegres que passamos juntos e por me ajudarem nos experimentos e nas discussões científicas. Agradeço principalmente à Adriana Wendel, Felippe Truglio, Rebeca Bueno e Mateus Mori. Um agradecimento especial a Fernanda Rowies que esteve comigo durante toda a execução do trabalho no IQ e por tornar leve o dia-a-dia. Sempre é divertido fazer experimento com você.

Ao Adilson da Silva Alves, por todo o auxílio na execução dos experimentos que estão apresentados aqui.

À CAPES, por todo o auxílio financeiro concedido ao departamento durante o período da realização desse estudo. 
Aos meus queridos pais, Alberto e Cláudia, por todo o apoio durante a minha trajetória de vida, principalmente nos passos da minha formação. Obrigada por acreditarem em mim, por estarem presentes tantos nos momentos alegres quanto difíceis e por vocês serem minha fonte de inspiração e porto seguro. Sem dúvidas, todas as minhas conquistas não seriam possíveis sem vocês! Amo vocês!

Aos meus irmãos, Leonardo e Rafaela, por estarem sempre ao meu lado e por me darem forças para seguir em frente. Não sei o que seria de mim sem vocês por perto. Amo vocês!

Aos meus avós, tios e primos pelo apoio, pelo incentivo e por estarem ao meu lado.

Aos meus amigos que estão presentes em cada conquista e que espero tê-los sempre ao meu lado. Dentre eles, agradeço especialmente a Carolina Carvalho, Juliana Della Nina, Cristiane Pelizon, Raphael Baston, Tulio Capelini, Aline Campos, Adriana Domarques, Gustavo Carvalho, Maíra Nagai, Gabriela Naomi, Alane Cangani, Luzia Lima, Keila Silva, Camila Sascimento, Livia Polichiso, Ana Teresa Alho, Débora Freitas e Rodrigo Avelaira. Obrigada pelos conselhos, pelo companherismo e pelas palavras sinceras.

Ao meu namorado e amigo, Víctor Vber Paschoalini, por todo o suporte na fase final dessa tese, por ter paciência nos momentos de desânimo, por acreditar em mim, por ser minha fonte de inspiração e por todo o companherismo e apoio. Obrigada por tudo! Amo você!

À todos os funcionários da USP que contribuíram direta ou indiretamente na elaboração dessa tese e na minha formação. Em especial, agradeço ao corpo docente pelos conhecimentos compartilhados $e$ pelas conversas científicas.

Finalmente, agradeço àqueles que, por ventura, eu possa ter me esquecido de citar, mas que acrescentaram peças importantes no meu crescimento pessoal e profissional durante esses anos.

Muito obrigada! 


\section{AGRADECIMENTOS}

À FAPESP pelo fornecimento da 6olsa de estudo no nível de doutorado ( $n^{\circ}$ do processo: 2015/03791-4) durante o período de 2015 a 2019, 6em como da 6olsa BEPE concedida durante o período de 10 meses ( $n^{\circ}$ do processo: 2017/09909-2) e por todo o financiamento do projeto que foram de extrema importância para a execução desse trabalho. 
"A mais bela coisa que podemos vivenciar é o mistério. Ele é fonte de qualquer arte verdadeira $e$ qualquer ciência. Aquele que desconhece esta emoção, aquele que não para mais para pensar $e$ não se fascina, está como morto: seus olhos estão fechados."

Albert Einstein 


\section{RESUMO}

Pereira, C. P. M. O papel da microglia no modelo da doença de Parkinson induzido pela 6-hidroxidopamina. Tese (Doutorado em Fisiologia Humana) Instituto de Ciências Biomédicas, Universidade de São Paulo, São Paulo, 2019.

A doença de Parkinson (DP) é considerada a segunda doença neurodegenerativa mais comum em idosos e é caracterizada pela presença de disfunções motoras decorrentes da redução de neurônios dopaminérgicos na substância negra pars compacta (SNpc). Uma das principais neurotoxinas utilizadas para o estudo de DP em modelos animais é a 6-hidroxidopamina (6-OHDA), que possui como mecanismo de neurotoxicidade a formação de espécies reativas de oxigênio (EROs). A liberação de EROs pela NADPH oxidase (Nox) e a ativação microglial constituem os eventos iniciais da neurodegeneração induzida pela 6-OHDA. A Nox2 está relacionada com a modulação dos fenótipos microgliais e encontra-se superativada na DP, levando a um desequilíbrio redox e a danos celulares. A microglia é o principal componente da defesa imune no sistema nervoso central (SNC) e é dependente do receptor fator 1 estimulador de colônias (CSF1R) para a sobrevivência. O inibidor de CSF1R é utilizado como método para depletar microglia em modelos de neurodegeneração e, consequentemente, compreender o impacto da sua eliminação no processo da doença. Baseado nisso, foram propostas duas abordagens para compreender o papel da microglia na progressão da DP induzida pela 6-OHDA, sendo que o primeiro investigou a modulação da ativação microglial pela Nox2 em camundongos nocautes para a subunidade gp $91^{\text {phox }}$, enquanto que o segundo avaliou o impacto da depleção por meio do tratamento com $1200 \mathrm{mg} / \mathrm{Kg}$ de PLX5622, um tipo de inibidor de CSF1R. Os animais naïves gp91 $1^{\text {phox-l }}$ apresentaram aumento da proliferação de microglias e da expressão da enzima iNOS. Quando submetidos à 6-OHDA, os nocautes não apresentaram declínio motor em função do tempo avaliado pelo teste do cilindro, devido à maior sobrevivência de neurônios dopaminérgicos na SNpc em relação aos selvagens (WT). Um dos possíveis fatores relacionados à perda expressiva de neurônios nos WT foi a indução precoce da enzima iNOS, sugerindo que a ativação de Nox2 conjuntamente com iNOS na microglia aumenta os níveis de EROs tornando os neurônios mais susceptíveis à morte celular. Também foram observadas modulações temporais distintas entre os grupos com relação à expressão de CD86 e Arginase-1, além dos nocautes apresentarem baixos níveis de 
lesões oxidativas no DNA mitocondrial quando comparado com os WT. Assim, a ativação da Nox2 e da iNOS parecem atuar em sinergia no processo neurodegenerativo causado pela 6-OHDA. Por outro lado, os resultados com PLX5622 mostraram que a depleção microglial acelera o comprometimento da coordenação motora e da bradicinesia avaliado pelo teste do poste, bem como reduz o número de neurônios dopaminérgicos na SNpc. Além disso, a redução de células postivas para GFAP, do marcador CD68 e da regulação de genes ligados a microglia foram observados. O gene $\mathrm{MeCP} 2$, que está relacionado à via nigroestriatal e que consiste em um importante modulador da expressão de $\mathrm{TH}$, está pouco expresso no grupo submetido à depleção microglial e à 6-OHDA. Esses achados sugerem que a deficiência na comunicação entre microglias e astrócitos, bem como a redução do nível de transcritos do gene MeCP2 causados pela depleção microglial, podem contribuir para a aceleração do processo neurodegenerativo causado pela 6-OHDA.

Palavras-chave: Microglia. Doença de Parkinson. 6-OHDA. NADPH oxidase. CSF1R. 


\section{ABSTRACT}

Pereira, C. P. M. Microglial role in a model of Parkinson's disease induced by 6hydroxydopamine. Thesis (PhD thesis in Human Physiology) - Biomedical Sciences Institute, Sao Paulo University, Sao Paulo, 2019.

Parkinson's disease (PD) is considered the second most common neurodegenerative disease in elderly people and is characterized by the presence of motor impairment, which is a consequence of dopaminergic neuron loss in the substantia nigra pars compacta (SNpc). A major neurotoxin used for PD study in animal models is 6hydroxydopamine (6-OHDA), which exerts neurotoxic effects through the production of reactive oxygen species (ROS). ROS release by the enzyme NADPH oxidase (Nox) and microglial activation are early events of neurodegeneration induced by 6 OHDA. Nox2 is related to modulation of microglia phenotypes and is overactivated in PD, which can lead to redox imbalance and cellular damage. Microglial cells are the main components of immune defense in the central nervous system and are dependent upon Colony-stimulating factor 1 receptor (CSF1R) for survival. The CSF1R inhibitor is used with a tool to deplete microglia in models of neurodegenerative diseases and, consequently, to understand the impact of its elimination in the disease process. Based on that, we proposed two approaches to evaluate the microglial role in the PD progression induced by 6-OHDA, in which the first one investigated the modulation of microglial activation by Nox2 in gp91 ${ }^{\text {phox }}$ knockout mice, whereas the second one evaluated the impact of microglial depletion through a treatment with $1200 \mathrm{mg} / \mathrm{Kg}$ of PLX5622, one type of CSF1R inhibitor. The gp91 ${ }^{\text {phox-l- }}$ naïve mice showed an increase of microglia proliferation and in the iNOS expression. When the knockout mice were submitted to 6-OHDA, they did not have motor impairments as a function of toxin exposure as evaluated by cylinder test. This result is due to the increase number of dopaminergic neurons survival in SNpc compared to wild type (WT). One of the possible factors involved in neurons death in WT was the early iNOS induction, which indicates that Nox2 and iNOS simultaneous activation in microglial cells enhance ROS levels, leading to neurons more vulnerable to cell death. Moreover, the expression of CD86 and Arginase-1 have differences in temporal modulation between both groups, as well as knockout mice showed lower levels of oxidative damage in mitochondrial DNA when compared with WT. Thus, the activation of Nox2 and iNOS could act sinergically in the neurodegenerative process 
caused by $6-O H D A . O n$ the other hand, results with PLX5622 indicated that the microglial depletion aggravates the impairment of bradykinesia and motor coordination evaluated by pole test, as well as the reduction of tyrosine hydroxylase (TH) positive neurons in the SNpc. Moreover, the decrease of GFAP positive cells, of CD68 marker and regulation of genes linked to microglia were observed. The MeCP2 gene, related to the nigrostriatal pathway and an important modulator of $\mathrm{TH}$ expression, is down-regulated in the group with microglial elimination and submitted to 6-OHDA. These findings suggest that the deficiency of crosstalk between astrocytes and microglia, as well as the reduced MeCP2 transcript levels may contribute to the acceleration of neurodegenerative process initiated by 6-OHDA.

Keywords: Microglia. Parkinson's disease. 6-OHDA. NADPH oxidase. CSF1R. 


\section{LISTA DE FIGURAS}

Figura 1. Via direta e indireta do circuito motor.

Figura 2. Mecanismo de ativação das subunidades da enzima Nox e a formação de EROs. .37

Figura 3. Desenho experimental da análise do processo neurodegenerativo e do perfil microglial de camundongos C57BI6 e nocautes para Nox2. 42

Figura 4. Representação de um gel de agarose de $3 \%$ para a verificação da ausência do gene $C Y B B$ nos camundongos gp $91^{\text {phox-l- }}$ .55

Figura 5. Densidade integrada das células marcadas com lba-1 e iNOS no CPu e na SNpc de camundongos selvagens e nocautes naïves .57

Figura 6. Verificação do transporte retrógrado do FluoroGold para a SNpc e marcação dos neurônios dopaminérgicos com o anticorpo para TH. .59

Figura 7. Camundongos gp91 ${ }^{\text {phox-l- }}$ e submetidos à 6-OHDA não apresentaram déficit motor avaliado pelo teste do cilindro.

Figura 8. Após 3 dias de indução com 6-OHDA, não foi observada redução significativa da marcação de TH tanto no CPu quanto na SNpc nos animais WT e KO. .63

Figura 9. Aumento da densidade de microglia ativada no lado com 6-OHDA da SNpc apenas é observado nos $\mathrm{KO}$ após 3 dias.

Figura 10. Após 3 dias da neurotoxina, a marcação de iNOS está elevada significativamente no CPu e na SNpc dos WT.

Figura 11. A marcação de TH nos terminais e nos neurônios dopaminérgicos está reduzida significativamente nos WT e KO após 15 dias de indução de DP.

Figura 12. Após 15 dias de cirurgia, houve aumento da densidade de microglia no lado com 6-OHDA do CPu e da SNpc dos WT e KO.

Figura 13. Após 15 dias de cirurgia, houve aumento da marcação de iNOS no lado com 6-OHDA da SNpc dos WT e KO.

Figura 14. Comparações entre os camundongos WT e KO das relações obtidas entre os lados controle e experimental após 3 e 15 dias da injeção com 6OHDA.

Figura 15. Representação de um gel de agarose $1 \%$ para a verificação da integridade do RNA de amostras testes de CPu e SN. 
Figura 16. Representação de um gel de agarose de $1 \%$ para a verificação da integridade do RNA das amostras de SN.

Figura 17. Gráficos das curvas padrões dos oito primers utilizados nesse estudo. .82

Figura 18. Gráficos das expressões gênicas de TH, CD86 e Arg-1 na SN dos animais WT e KO em função dos períodos de 3, 6, 9 e 15 dias após a injeção de 6-OHDA

Figura 19. Análise da presença de lesões no DNA nuclear e mitocondrial em amostras de SN de animais WT e KO tratados com veículo ou 6-OHDA. .87

Figura 20. Desenho experimental da eliminação microglial em camundongos C57BI6 submetidos à injeções com 6-OHDA (modelo de DP) ou com veículo (controle). .104

Figura 21. Depleção microglial aumenta a disfunção motora em camundongos submetidos à 6-OHDA no teste do poste. 110

Figura 22. Distância percorrida e velocidade média do teste de campo aberto não foram influenciados pela 6-OHDA e pelo tratamento com PLX5622. .112

Figura 23. A indução pela 6-OHDA reduziu o tempo médio de permanência no teste rota rod somente no sétimo dia. .113

Figura 24. Análise das razões de finalização no teste do rota rod .114

Figura 25. A expressão de TH está reduzida significativamente na SNpc dos camundongos submetidos às injeções de 6-OHDA e à depleção microglial.

Figura 26. O número de células microgliais e a intensidade do marcador CD68 estão reduzidos nos grupos WT e DP tratados com PLX5622 na SNpc.

Figura 27. Tratamento com PLX5622 reduz significativamente a co-localização entre os marcadores lba-1 e CD68 na SNpc do grupo DP 120

Figura 28. No $\mathrm{CPu}$, as células lba-1+ e CD68+ estão reduzidas nos grupos submetidos à depleção microglial. 122

Figura 29. No CPu, a co-localização entre os marcadores lba-1 e CD68 está reduzida nos grupos tratados com PLX5622.

Figura 30. Co-localização dos marcadores TMEM119 e Iba-1 na SNpc nos quatro grupos. 126

Figura 31. Co-localização dos marcadores P2RY12 e lba-1 na SNpc dos quatro grupos analisados .127 
Figura 32. A porcentagem de área marcada com GFAP está reduzida nos grupos submetidos ao inibidor CSF1R na SNpc.

Figura 33. No $\mathrm{CPu}$, camundongos com depleção microglial e submetidos à 6-OHDA apresentaram aumento da porcentagem de área marcada com GFAP quando comparado com WT PLX5622................................................131

Figura 34. Diagrama de Venn mostrando o número de genes em comum para cada comparação, seguida de tabelas com os genes especificados.................133

Figura 35. Análise do heat map da expressão gênica...........................................134 


\section{LISTA DE TABELAS}

Tabela 1: Sequência de primers utilizados na genotipagem dos nocautes ...............47

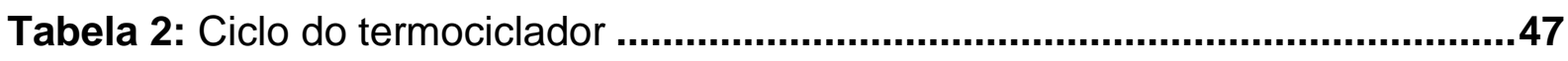

Tabela 3. Sequência de primers utilizados na reação de PCR em tempo real .........50

Tabela 4. Primers utilizados na reação de PCR de longa extensão ........................51

Tabela 5. Concentrações e dados da pureza das amostras de RNA testes da SN ..77

Tabela 6. Concentrações e dados da pureza de amostras de RNA da SN ...............79

Tabela 7. Dados da reta da curva e da eficiência dos primers utilizados ..................83 


\section{LISTA DE ABREVIATURAS}

3xTgAD - camundongo triplo trangênico para os genes PSEN1, APPSwe e tauP301L

5xTgAD - modelo murino que super expressa 5 genes mutados referentes à doença de Alzheimer familiar.

6-OHDA - 6-hidroxi-dopamina

AP - sítio abásico

ARG1- Arginase-1

a-syn - alfa-sinucleína

ATP - Adenosina trifosfato

$\mathrm{Ca}^{2+}$ - íon Cálcio

CD68 - Cluster of differentiation 68

CGD - doença granulomatosa crônica

COX - ciclo-oxigenase

CPu - Caudado e putâmen

CSF1R - Colony-stimulating factor 1 receptor

DA - Doença de Alzheimer

DAB - 3-3' diaminobenzidina

DAMPs - padrões moleculares associados ao dano tecidual

DNAmt- DNA mitocondrial

DNAn- DNA nuclear

DP - Doença de Parkinson

Duox - Dual oxidase

ERNs - Espécies reativas de nitrogênio

EROs - espécies reativas de oxigênio

$\mathrm{Fe}^{2+}$ - íon ferro II ou ferroso

GABA - ácido $y$-amino-butírico

GFAP - Glial fibrillary acidic protein

gp9 $1^{\text {phox-/- }}$ - nocaute para a subunidade gp9 ${ }^{\text {phox }}$ da Nox2

GPe - Globo Pálido externo

GPi - Globo pálido interno

GSH - Glutationa na forma reduzida

$\mathrm{H}_{2} \mathbf{O}_{2}$ - peróxido de hidrogênio 
Iba-1 - Molécula 1 adaptadora ligante de cálcio ionizado

IFN-Y - Interferon- $\mathrm{Y}$

IL - Interleucina

KO - nocaute

iNOS - óxido nítrico sintase induzível

IRF-8 - interferon regulatory factor 8

LAMP - Lysosomal associated membrane glycoprotein

LPS - lipopolissacarídeo

LTD - depressão de longa duração

LTP - potenciação de longa duração

MO - microglia no estado de repouso

M1 - ativação clássica da microglia

M2 - ativação alternativa da microglia

MAO - Monoamina Oxidase

MeCP2 - Methyl-CpG-binding protein 2

MHC II - major histocompatibility complex class II

MMP - metaloproteinases de matriz

MPTP - 1-metil-4-fenil-1,2,3,6-tetraidropiridina

MSN - neurônios espinhosos médios

NADPH - nicotinamida adenina dinucleotídeo fosfato

NF-kB - Fator nuclear kappa B

NK - natural killer

NO - óxido nítrico

Nox - NADPH oxidase

NST- núcleos subtalâmicos

$\mathrm{O}_{2}{ }^{\circ-}$ - radical ânion superóxido

$\mathbf{O H}^{\bullet}$ - radical hidroxila

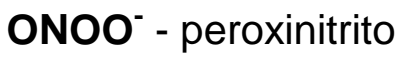

PAMPs - padrões moleculares associados à patógenos

PB - tampão fosfato

PCNA - antígeno nuclear de proliferação celular

PFA - paraformaldeído

$\mathbf{P G E}_{2}$ - prostaglandinas $\mathrm{E}_{2}$

PRR - receptores de reconhecimento padrão 
Pu.1 - PU box binding-1

RNAm - RNA mensageiro

RT-PCR - reação em cadeia da polimerase em tempo real

RTT - Síndrome de Rett

SN - substância negra

SNC - Sistema Nervoso Central

SNpc - Substância Negra pars compacta

SNr - Substância negra pars reticulata

SOD - superóxido dismutase

STAT3 - signal transducers and activators of transcription

TGF- $\beta$ - Fator de transformação de crescimento beta

TH - Tirosina hidroxilase

TLRs - Tool-like receptors

TNF- $\alpha$ - Fator de necrose tumoral $\alpha$

UTP - uridina-5'-trifosfato

WT - selvagem

YM1 - chitinase-like 3 


\section{SUMÁRIO}

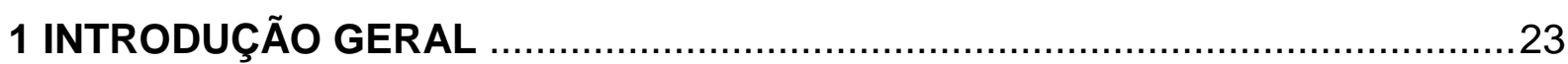

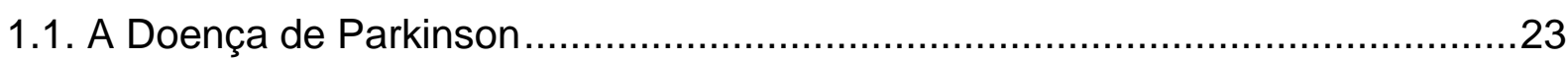

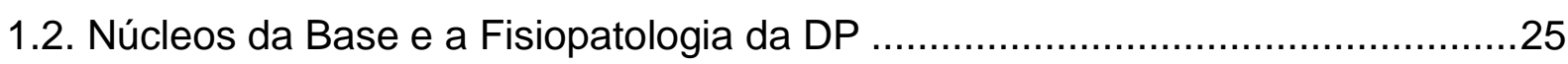

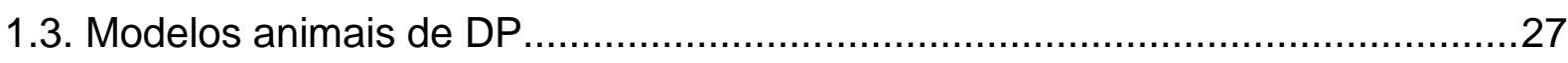

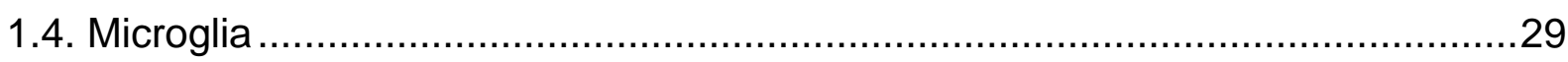

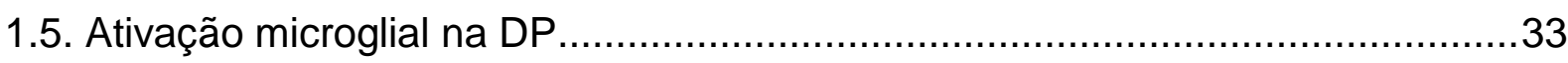

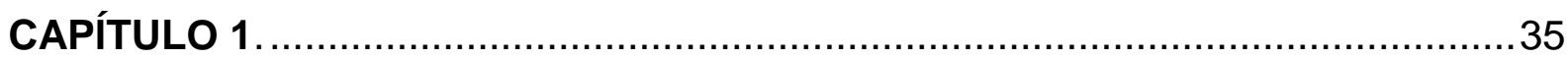

1 INTRODUÇÃO

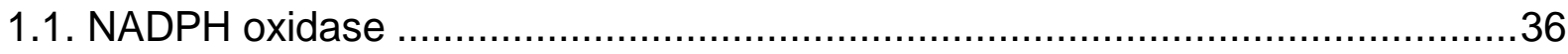

1.2. Nox2 apresenta papel modulador na resposta microglial durante a DP .............38

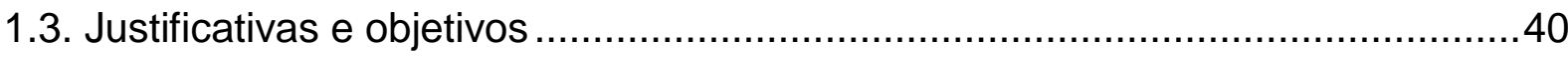

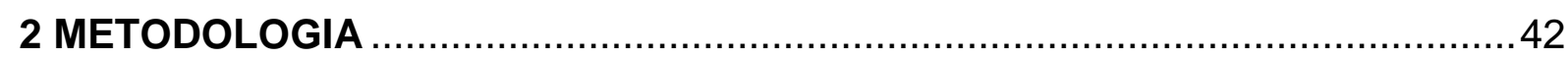

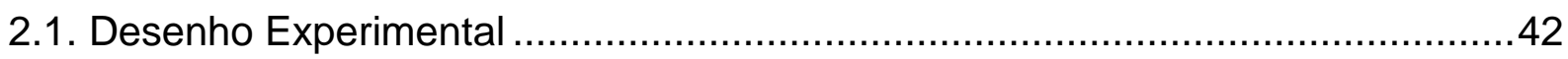

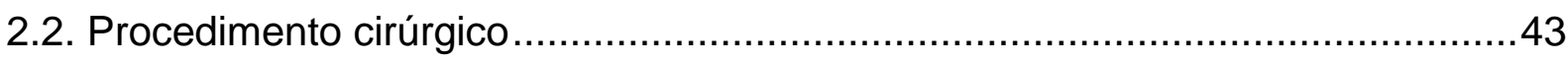

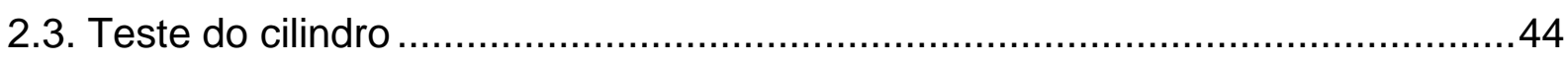

2.4. Marcação retrógrada de neurônios da substância negra com Fluoro-Gold.........44

2.5. Imuno-histoquímica (Imunoperoxidase) …………........................................45

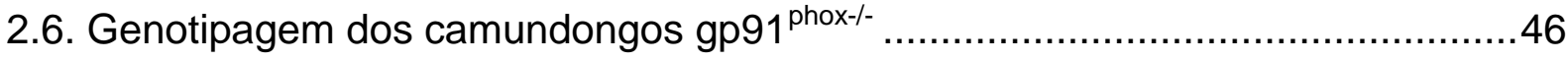

2.7. Extração de RNA para Real Time PCR e verificação da integridade de RNA....48

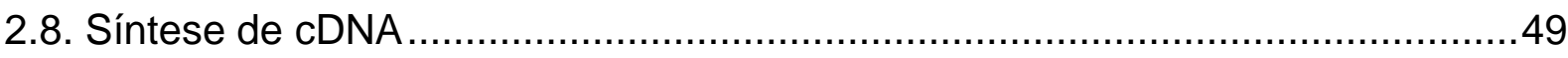

2.9. Padronização da quantidade de cDNA utilizada para a reação de $P C R$ em

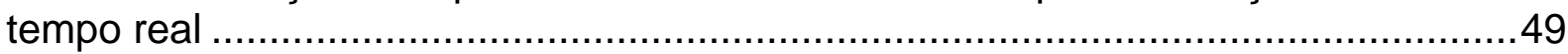

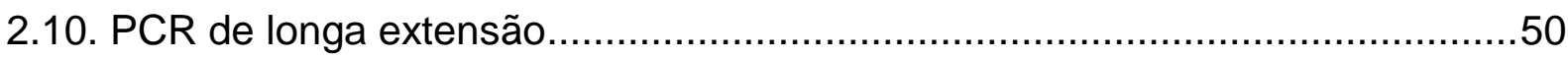

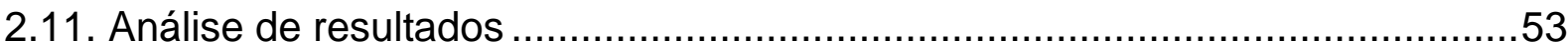

3 RESULTADOS 
3.1. Genotipagem dos camundongos nocautes para a subunidade $g p 91^{\text {phox }}$

3.2. Perfil microglial dos camundongos naïves selvagens e nocautes (gp91 phox ${ }^{-1}$ ) 55

3.3. Marcação retrógrada de neurônios dopaminérgicos da substância negra .58

3.4. Perfomance no teste do cilindro 60

3.5. Curva do perfil microglial versus o tempo após a injeção da droga 6-OHDA .....61

3.5.1. Perfil neurodegenerativo e microglial após 3 dias da cirurgia. .62

3.5.2. Perfil neurodegenerativo e microglial após 15 dias da cirurgia 68

3.5.3. Relação entre o lado experimental e controle dos marcadores analisados após 3 e 15 dias de cirurgia. . .74

3.5. Expressão gênica de Arginase-1, CD86 e Tirosina hidroxilase por meio do PCR em tempo real.

3.5.1. Padronização da extração de RNA. . .77

3.5.2. Padronização da quantidade de cDNA utilizada para cada primer

3.5.3. Expressão gênica de Arginase-1, CD86 e Tirosina Hidroxilase na SN em função do tempo após a indução de DP . .83

3.6. Análise das lesões no DNA nuclear e mitocondrial da SN .85

3.7. Resumo dos resultados .87

4 DISCUSSÃO .90

CAPÍTULO 2 .99

1 INTRODUÇÃO 100

1.1. Justificativas e objetivos 102

2 MATERIAIS E MÉTODOS 104

2.1. Desenho experimental. 104

2.2. Indução da DP. 105

2.3. Teste de campo aberto 105

2.4. Teste do Poste 106

2.5. Rota rod. 106 


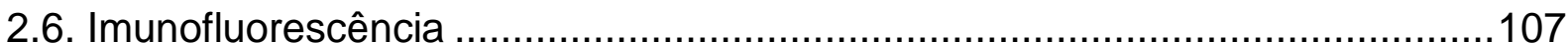

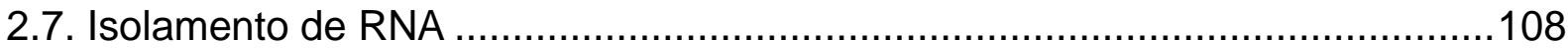

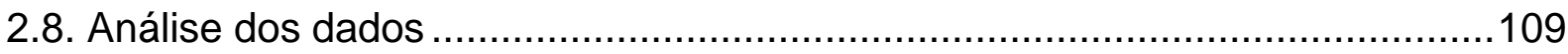

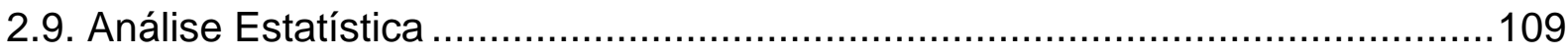

3 RESULTADOS

3.1. Performance no teste do poste .............................................................110

3.2. Análise do Campo Aberto.........................................................................111

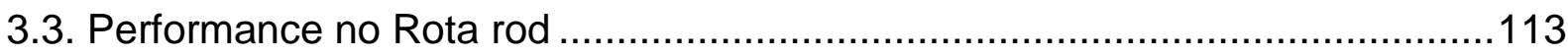

3.4. Quantificação dos neurônios dopaminérgicos na SNpc .................................114

3.5. Quantificação das células microgliais e do marcador CD68 na SNpc..............115

3.6. Quantificação das células microgliais e de CD68 no CPu..............................121

3.7. Expressão de TMEM119 e P2RY12 na substância negra...............................125

3.8. Expressão de marcadores de astrócitos .....................................................127

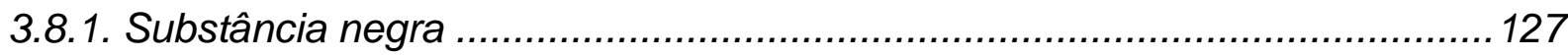

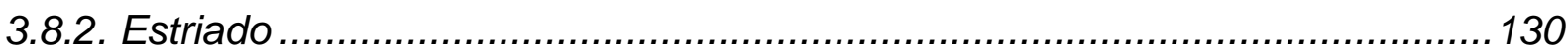

3.9. Quantificação dos níveis de transcritos na substância negra..........................132

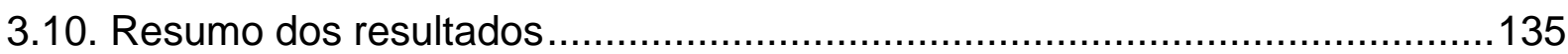

4 DISCUSSÃO

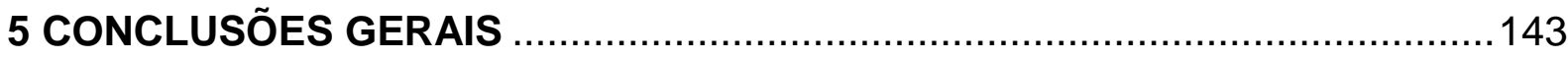

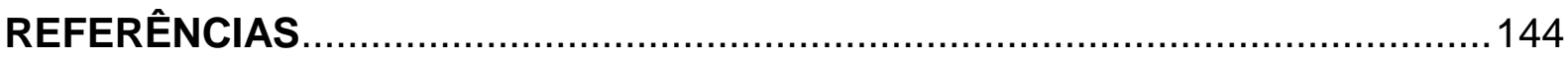




\section{INTRODUÇÃO GERAL}

\subsection{A Doença de Parkinson}

O envelhecimento populacional ocorre de maneira acelerada, e segundo as projeções do Instituto Brasileiro de Geografia e Estatística - IBGE (1), o número de idosos (acima de 60 anos) em 2030 irá superar o número de crianças (menores de 15 anos de idade) em torno de 4 milhões. Em 2050, essa diferença passará para 35,8 milhões, totalizando nesse ano 64,1 milhões de idosos no Brasil. A alta proporção de idosos resulta em consequências diretas aos sistemas de saúde pública, como o aumento dos custos dos tratamentos médico-hospitalares decorrentes, principalmente, do aumento da incidência e prevalência das doenças associada à idade como, por exemplo, a doença de Parkinson.

A doença de Parkinson (DP) é considerada a segunda doença neurodegenerativa mais comum, ficando apenas depois da doença de Alzheimer (DA). Em países de alto poder econômico, as taxas de incidência anuais estabelecidas por idade média consistem em 14 por 100.000 pessoas na população total e 160 por 100.000 pessoas com mais de 65 anos de idade (2). Além disso, estima-se que o número de pessoas com DP em 2030 será maior que $50 \%$ em relação ao número de 2005 (3). A fase inicial da doença é rara antes dos 50 anos de idade e sua incidência aumenta significativamente após os 60 anos (4). Em um estudo realizado na cidade de Bambuí, no estado de Minas Gerais, os autores identificaram uma prevalência da DP de 3,3\% em uma população com idade média de 73,5 \pm 6,9 anos (5).

Em 1817, James Parkinson descreveu os sintomas da paralisia agitante no artigo intitulado "An essay on the shaking palsy", que posteriormente foi denominada como Doença de Parkinson por Jean-Martin Charcot (6). A DP é considerada, do ponto de vista clínico, como uma condição neuropatológica progressiva lenta, caracterizada pelo tremor, rigidez, bradicinesia e instabilidade postural. Contudo, esses sintomas clínicos apenas se manifestam quando a ocorrência de morte neuronal é em torno de $70-80 \%$ (7). A demência pode ocorrer em aproximadamente $20 \%$ a $60 \%$ dos indivíduos com DP, e é mais comum naqueles indivíduos mais idosos ou com um quadro mais severo da doença. O termo demência pode ser definido como declínio de memória associado ao comprometimento de pelo menos outra função cognitiva (linguagem, gnosia, praxia ou funções executivas), com 
intensidade suficiente para causar um impacto significativo nas atividades sócioocupacionais do indivíduo. A demência associada à DP é caracterizada por lentidão motora e cognitiva, disfunção executiva e comprometimento na recuperação da memória (8).

Do ponto de vista neuropatológico, a DP é caracterizada pela redução de projeções dopaminérgicas no estriado, devido à degeneração neuronal na substância negra pars compacta (SNpc). Também é caracterizada pela presença de corpos e neuritos de Lewy (9). Os corpos e neuritos de Lewy também são encontrados em outras regiões cerebrais como no núcleo motor dorsal do vago, no núcleo basal de Meynert e no locus coeruleus (10). O estudo de Spillantini e colaboradores (11) demonstrou que os corpos e neuritos de Lewy de amostras cerebrais de pacientes com DP apresentaram forte imunorreatividade para $\alpha$ sinucleína, indicando que modificações nessa molécula são responsáveis pela formação desses achados neuropatológicos.

A a-sinucleína (a-syn) é uma proteína de 14kDa constituída por 140 aminoácidos. Está localizada tanto em terminais pré-sinápticos e núcleo (12) quanto no citosol e em algumas membranas celulares como a membrana do retículo endoplasmático associado à mitocôndria (13). Existem, até o momento, seis tipos diferentes de mutações missense (p.A53T, p.A30P, p.E64K, p.H50Q, p.G51D, p.A53E) no gene que codifica a a-sinucleína (SNCA) que são determinantes no desenvolvimento da forma autossômica dominante da DP. A função dessa proteína ainda não está estabelecida, porém evidências sugerem que está relacionada com sua capacidade de interagir diretamente com membranas fosfolipídicas, em particular com vesículas da neurotransmissão sináptica (14).

Outros genes que estão associados à forma autossômica dominante da DP são: LRRK2, VPS35, EIF4G1, DNAJC13 e CHCHD2. LRRK2 codifica a leucine-rich repeat kinase 2, uma proteína com vários domínios que apresenta importantes funções no crescimento neurítico, na morfogênese sináptica, no tráfego de membrana, na autofagia, na síntese proteica e no sistema imune inato. Já mutações nos genes Parkin, PINK1 e DJ-1, que são importantes para o bom funcionamento da mitocôndria, correspondem à forma recessiva da DP e está associada ao seu início precoce (idade anterior aos 40 anos)(15).

Entretanto, cerca de $90 \%$ dos casos diagnosticados não são familiares e sim esporádicos, indicando a importância de fatores ambientais para o início dessa 
doença (16). Um fator ambiental que aumenta o risco de DP é a exposição a pesticidas, como por exemplo: o paraquat, a rotenona e pesticidas organoclorados. Por possuírem propriedades lipofílicas, estas moléculas atravessam a barreira hemato-encefálica, e causam a morte neuronal dopaminérgica por meio do aumento dos níveis de estresse oxidativo que pode ocorrer via bloqueio de complexos da cadeia transportadora de elétrons mitocondrial e/ou via ativação microglial (17).

\subsection{Núcleos da Base e a Fisiopatologia da DP}

A execução do movimento voluntário depende do processamento correto das informações sensório-motoras no cérebro, sendo que esse processo envolve uma rede neural complexa entre o córtex motor, os núcleos da base e o tálamo (18). Os núcleos da base consistem em: neoestriado (núcleo caudado e putâmen - $\mathrm{CPu}$ ), segmentos externo e interno do globo pálido (GPe e GPi), os núcleos subtalâmicos (NST) e a substância negra (SN).

O estriado é composto em sua maior parte por projeções de neurônios espinhosos médios (MSN) que utilizam o ácido y-amino-butírico (GABA) como neurotransmissor, bem como por projeções de neurônios dopaminérgicos. Esse núcleo da base é a principal estrutura que recebe impulsos nervosos na circuitaria dos gânglios da base e recebe projeções glutamatérgicas de todas as áreas corticais. Os principais alvos dessa estrutura são o globo pálido e a substânica negra pars reticulata $(\mathrm{SNr})(18)$.

A SN é classificada em pars reticulata e pars compacta. A SNpc contém neurônios que possuem neuromelanina e apresentam como neurotransmissor a dopamina (18). Os principais receptores das projeções nigrais são o CPu, GP e NST. Já a SNr está localizada ventralmente e adjacente a SNpc, e contém neurônios GABAérgicos. Suas projeções inibitórias são enviadas principalmente ao núcleo ventral anterior e ventral lateral do tálamo (19).

A ocorrência do movimento depende de dois circuitos que são conhecidos como via direta e indireta. A via direta corresponde à ativação cortical por meio da liberação de glutamato e posterior ativação de MSN do estriado que se projetam para a SNr e o GPi. Os MSNs são GABAérgicos, ou seja, exercem uma ação inibitória nos neurônios da SNr e do GPi, que também são GABAérgicos. Essa inibição do SNr/GPi leva a desinibição dos neurônios glutamatérgicos do tálamo que apresentam projeções para o córtex motor. Assim, a via direta favorece o movimento 
(Figura 1) (20, 21). Já a via indireta corresponde aos MSNs do estriado que se conectam ao SNr/GPi por meio do GPe e do NST. Os MSNs estriatais inibem os neurônios GABAérgicos do GPe, levando a desinibição dos neurônios glutamatérgicos do NST, que por sua vez, ativam os neurônios GABAérgicos do SNr/GPi que se projetam para o tálamo. A inibição do tálamo possibilita a redução do movimento (revisado em $(20,21)$ ).

Além disso, o estriado recebe uma densa inervação de neurônios dopaminérgicos da SNpc que atua como um importante modulador da atividade estriatal. Os MSNs da via direta e indireta são caracterizados por expressar diferentes receptores dopaminérgicos, sendo que o receptor D1 é expresso na direta e o D2 na indireta. Como esses receptores estão acoplados a diferentes proteínas $\mathrm{G}$, sua ativação leva a distintas respostas bioquímicas. A ativação do receptor D1 aumenta a excitabilidade dos MSNs da via direta, facilitando a potenciação de longa duração (LTP) das sinapses glutamatérgicas, enquanto que a ativação do receptor D2 reduz a excitabilidade da via indireta, promovendo a depressão de longa duração (LTD) nas sinapses corticais (22). A diferente modulação das sinapses pelos receptores dopaminérgicos nas vias direta e indireta desencadeia a redução da inibição da projeção dos neurônios talamocorticais, possibilitando a ocorrência do movimento (21).

Na DP, a perda dos neurônios dopaminérgicos na SNpc resulta em respostas distintas nos MSNs estriatais da via direta e indireta. A redução dos níveis de dopamina na via direta leva a diminuição da atividade dos neurônios, enquanto que na via indireta ocasiona a hiperatividade. Consequentemente, o GPe é inibido pelo estriado, possibilitando a desinibição dos neurônios do NST e posterior excitação do GPi e SNr. O aumento da atividade de GPi e SNr é reforçado pela ausência da inibição dos neurônios da via direta. Dessa forma, há um aumento da inibição do tálamo, impedindo a ocorrência da atividade locomotora (21). 
Figura 1. Via direta e indireta do circuito motor.

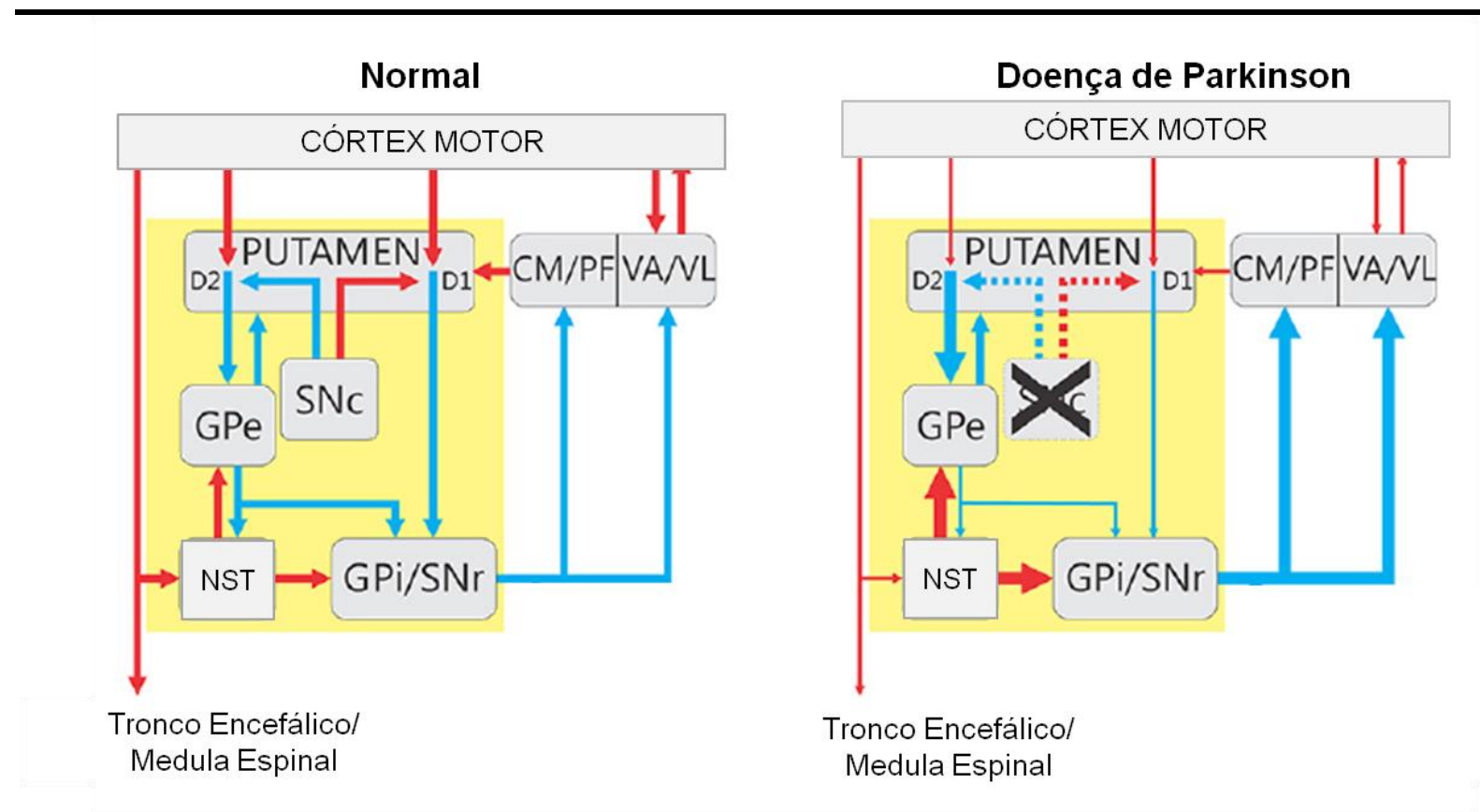

A imagem da esquerda indica os circuitos que estão presentes no estado normal, enquanto que a da direita esquematiza as vias que estão comprometidas na Doença de Parkinson. As setas azuis e vermelhas correspondem às conexões inibitórias e excitatórias, respectivamente. Além disso, as espessuras das setas indicam a força da sua atividade e a caixa amarela representa as interligações dos núcleos da base que recebem as conexões das regiões talâmicas e corticais. Abreviações: D1 e D2 = subtipos de receptores dopaminérgicos; $\mathbf{G P e}=$ Globo Pálido Externo; $\mathbf{G P i}=$ Globo Pálido Interno; NST= Núcleo Subtalâmico; SNc= Substância negra pars compacta; $\mathbf{S N r}=S$ ubstância negra pars reticulata; $\mathbf{C M}=$ Núcleo talâmico centromedial; PF = Núcleo talâmico parafascicular; VA= núcleo subtalâmico ventral anterior; $\mathbf{V L}=$ núcleo subtalâmico ventrolateral.

Fonte: Adaptado de (21)

\subsection{Modelos animais de DP}

O desenvolvimento de modelos animais para a DP é fundamental para a compreensão da patogênese, dos mecanismos responsáveis pela progressão da doença e também para testar estratégias terapêuticas. Atualmente, os modelos animais de DP mais bem caracterizados são: 1-metil-4-fenil-1,2,3,6-tetrahidropiridina (MPTP), 6-hidroxidopamina (6-OHDA), paraquat e rotenona. Todas essas toxinas apresentam como característica comum a morte seletiva de neurônios dopaminérgicos por meio do estresse oxidativo (23).

A 6-OHDA é um análogo hidrolisado da dopamina, foi a primeira neurotoxina de neurônios dopaminérgicos descoberta e é a mais utilizada tanto em ensaios in vivo quanto in vitro $(24,25)$. Como essa molécula não atravessa a barreira hemato- 
encefálica, o estudo dos seus efeitos só é possível por meio de injeções intracerebrais. Ungerstedt (26) foi o primeiro a testar o efeito da injeção de 6-OHDA no CPu e na SN em ratos e descobriu que essa droga degenera tanto os terminais nervosos quanto os corpos celulares de neurônios dopaminérgicos do sistema nigroestriatal. Quando essa toxina é administrada unilateralmente no estriado, ocorre a perda dos terminais nigroestriatais com posterior degeneração retrógrada e progressiva dos corpos dopaminérgicos na SNpc, sendo essa redução significativa após uma e duas semanas das injeções (27).

Essa molécula foi considerada um potencial fator neurotóxico na patogênese de DP devido às evidências do seu acúmulo em urinas de pacientes com DP tratados com L-dopa (28), uma vez que sua formação in vivo ocorre por meio da

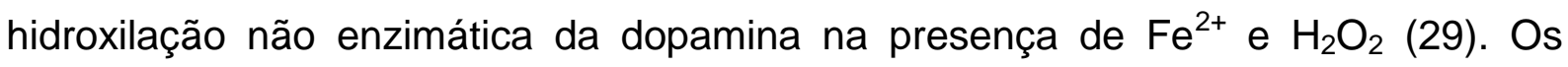
mecanismos responsáveis pela morte celular de neurônios dopaminérgicos por meio da administração de 6-OHDA ainda não estão totalmente estabelecidos, porém o estresse oxidativo e a disfunção mitocondrial estão envolvidos. A formação de espécies reativas de oxigênio (EROs) pode ocorrer por dois mecanismos, sendo eles: a deaminação pela Monoamina Oxidase (MAO) (30) e a auto-oxidação (31). O processo de auto-oxidação compreende a reação espontânea da 6-OHDA com o oxigênio, levando a formação de quinona e $\mathrm{H}_{2} \mathrm{O}_{2}$ (32). Nas fases intermediárias dessa reação é gerado o radical ânion superóxido $\left(\mathrm{O}_{2}{ }^{--}\right)$, que atua como 0 catalisador da auto-oxidação (33). $\mathrm{O}_{2}{ }^{\circ-}$ pode gerar outras espécies reativas como, por exemplo, o radical hidroxila $\left(\mathrm{OH} \bullet\right.$ ) a partir da reação com $\circ \mathrm{H}_{2} \mathrm{O}_{2}$ (33). Dessa forma, a auto-oxidação de 6-OHDA gera três produtos tóxicos para o neurônio, que são: a quinona, $\mathrm{O}_{2} \mathrm{O}_{2}$ e $\mathrm{O}_{2}^{--}$(33). Além disso, verificou-se que a indução por 6OHDA reduz a atividade de algumas enzimas antioxidantes, como a glutationa (GSH) e a superóxido dismutase (SOD), aumentando assim, o dano oxidativo (34).

Outro mecanismo pelo qual a toxina pode causar um desequilíbrio redox é a sua ação como um inibidor direto dos complexos I e IV da cadeia respiratória de elétrons mitocondrial, levando a deficiência na respiração mitocondrial e consequente morte celular (35). Apesar desses dois mecanismos de ação não estarem ligados, eles agem sinergicamente durante o processo neurodegenerativo (36). Rodriguez-Palhares e colaboradores (25) sugeriram que a ativação microglial e a liberação de EROs da NADPH oxidase (Nox) constituem os eventos iniciais da neurodegeneração induzida pela 6-OHDA, além de atuarem em sinergia com a 
neurotoxina para induzir a morte celular de neurônios dopaminérgicos nos estágios iniciais da lesão.

A utilização do modelo de 6-OHDA para estudar a DP é vantajosa, visto que consiste em um procedimento pouco complexo e de baixo custo, bem como apresenta alta reprodutibilidade com reduzida variabilidade individual (37). Outro aspecto que deve ser levado em consideração é a versatilidade, uma vez que pode ser induzida uma neurodegeneração completa e imediata quando são realizadas injeções de 6-OHDA na SN ou uma neurodegeneração parcial e progressiva quando a indução é no CPu. Ademais, a indução unilateral, também conhecida como modelo de hemiparkinsonismo, permite o estudo de intervenções terapêuticas e de mecanismos moleculares utilizando como controle o hemisfério intacto do mesmo animal (37). Entretanto, esse modelo não mimetiza algumas características clínicas e patológicas da DP em humanos, tais como: a não ocorrência da formação de corpos de Lewy; a ausência do comprometimento de outras áreas cerebrais como estruturas anteriores olfatórias; e a pouca recorrência de estudos reportando tremores em repouso em roedores, apesar de existirem relatos de acinesia e rigidez (36).

\subsection{Microglia}

O mecanismo que leva a progressão crônica das doenças neurodegenerativas ainda é inconclusivo. Entretanto, uma das características compartilhadas por vários tipos de doenças neurodegenerativas é a presença da neuroinflamação. Atualmente, a neuroinflamação é aceita como uma "faca de dois gumes" (38), uma vez que evidências apontam que a neuroinflamação exerce papéis prejudiciais nas doenças neurodegenerativas $(39,40)$, enquanto que outros estudos indicam que a inflamação é crucial para a recuperação em certas circunstâncias (41, 42). Gao e Hong (43) sugeriram que o processo inflamatório descontrolado é determinante para a progressão da DP e de outras doenças neurodegenerativas. Análises post-mortem de cérebros de pacientes com DP revelaram a presença de microglia ativada e aumento de mediadores inflamatórios na SN, sugerindo assim, o envolvimento da inflamação na doença (44).

A microglia, um subtipo de célula glial, é o principal componente da defesa imune intrínseca no sistema nervoso central (SNC). No SNC totalmente desenvolvido, a microglia é numerosa e distribuída por todo o parênquima cerebral. 
Pio Del Rio Hortega foi o primeiro a reconhecer a importância dessa célula em condições patológicas, foi responsável por nomeá-la e também propôs que a microglia era originada da invasão de elementos mesodermais no SNC, tendo como potencial fonte as células mononucleares do sangue (45). Entretanto, foi proposto que as células progenitoras da microglia encontram-se no saco vitelino e que durante o desenvolvimento embrionário e pós-natal, células microgliais que expressam o marcador mitótico PCNA são responsáveis pela proliferação das microglias que ocuparão todo o parênquima cerebral (46). Outro estudo mostrou que durante o processo ontogenético embrionário, progenitores eritromielóides $\mathrm{CD}^{\circ} 5^{-} \mathrm{c}$ $\mathrm{Kit}^{+}$do saco vitelino são os precursores microgliais e essas células passam por maturação e diferenciação via estágios $\mathrm{CX}_{3} \mathrm{CR} 1^{-}$e $\mathrm{CX}_{3} \mathrm{CR} 1^{+}$. Além disso, o processo de desenvolvimento microglial requer metaloproteinases de matriz, como MMP-8 e MMP-9, importantes para a expansão microglial, bem como envolve a presença de Irf8 e Pu.1 (47).

A morfologia típica da microglia humana consiste em células com vários processos pequenos e finos que abrangem uma extensa área e que se prolongam no ambiente circundante, promovendo assim uma boa localização para detectar e monitorar as alterações do ambiente local, como a presença de patógenos ou dano celular (48). Essa morfologia, que é conhecida como "ramificada", era identificada no passado como um estado inativo ou de "repouso" da célula glial (49). Entretanto, Nimmerjahn (50) mostrou que os processos da microglia estão em movimento em cérebros de camundongos, como se essas células estivessem constantemente monitorando o microambiente. Por outro lado, quando a microglia detecta a presença de corpos estranhos ou dano celular, ela torna-se ativada ou no estado "não-ramificado", com retração dos processos para o corpo celular. A retração completa dos processos origina a forma nomeada como ameboide em que a microglia encontra-se com alta mobilidade e fagocítica (51).

Como a microglia apresenta muitas proteínas em comum com os macrófagos, sua identificação precisa no parênquima cerebral é uma das dificuldades de se estudar seu comportamento tanto em modelos saudáveis quanto em modelos de doenças. Dentre os marcadores microgliais mais utilizados atualmente destacam-se OX42 (CD11b), Iba-1, CD68 e TMEM119. CD11b é uma subunidade do receptor de complemento tipo 3, que está localizado na membrana plasmática de neutrófilos, fagócitos mononucleares e células NK (natural killer) (52). Apesar de essa proteína 
não ser específica para a microglia, é utilizada para detectar a forma ativada dessas células (52). Iba-1 (Molécula 1 adaptadora ligante de cálcio ionizado) é uma proteína de peso molecular de 17kb, com 147 aminoácidos e pertencente ao grupo de proteínas ligantes de cálcio. Pouco é conhecido sobre a função dessa proteína, mas parece estar relacionada com a reorganização do citoesqueleto e alteração da conformação de processos que ocorrem durante a fagocitose (52). Uma das vantagens desse anticorpo é a estabilidade entre espécies dos epítopos antigênicos (52) e a desvantagem consiste em não ser específico a microglia, marcando também macrófagos (53). Na microglia, esse anticorpo marca a forma ramificada, ativada e ameboide $(53,54)$. Já CD68 (Cluster of differentiation 68 ) reconhece a macrosialina de murinos, que é uma proteína transmembrana glicosilada de cadeia pesada e pertencente à família LAMP (Lysosomal associated membrane glycoprotein) (55). Essa proteína é expressa intracelularmente em endossomos tardios de macrófagos e da microglia $(55,56)$ e sua função está associada ao metabolismo lisossomal e à atividades fagocíticas $(55,57)$. É utilizada principalmente como marcador secundário de microglia ativada (52). TMEM119 é uma proteína transmembrana de função desconhecida e específica da superfície celular microglial, não sendo expressa em macrófagos ou outras células neuronais (58). Em um estudo com cérebros humanos, TMEM119 co-localizou com as células microgliais marcadas com lba-1 e CD68 em amostras de indivíduos com DA, não sendo expressa nos macrófagos infiltrantes na presença de lesões desmielizantes da esclerose múltipla. Entretanto, essa proteína está relacionada com o fenótipo M0 (microglia residente), uma vez que o número de células TMEM119+ não se altera entre indivíduos com DA e sem a doença, além de não expressarem marcadores dos tipos de ativação microglial (M1 e M2)(59).

A microglia expressa diferentes receptores de reconhecimento padrão (PRR, do inglês pattern-recognition receptors), que podem ser classificados em: padrões moleculares associados a patógenos ou PAMPs (pathogen-associated molecular patterns) que reconhecem moléculas de microorganismos, e padrões moleculares associados a dano tecidual ou DAMPs (tissue damage-associated molecular patterns) que reconhecem produtos liberados por células danificadas, agregados peptídicos, entre outros (60). Um dos principais PAMPs presentes na microglia são os TLRs (Tool-like receptors) que além de reconhecer moléculas de vírus e 
bactérias, reconhecem moléculas endógenas como produtos metabólicos e agregados de proteínas disfuncionais como o peptídeo beta-amilóide (60).

A partir do reconhecimento de determinado patógeno ou de moléculas provenientes de danos no tecido cerebral, a microglia altera seu estado de repouso (M0) para o estado de ativação. A classificação desses fenótipos de ativação é similar à dos macrófagos. A ativação pode ser classificada em dois tipos de fenótipos: M1 ou ativação clássica e M2 ou ativação alternativa $(49,61)$. Os macrófagos M1 e M2 diferem nos seguintes aspectos: tipos de receptores, expressão de citocinas e de quimiocinas, e funções efetoras (62).

A ativação clássica ou M1 é caracterizada pela resposta à presença de microorganismos e é mediada por citocinas derivadas de células Th1, como por exemplo:

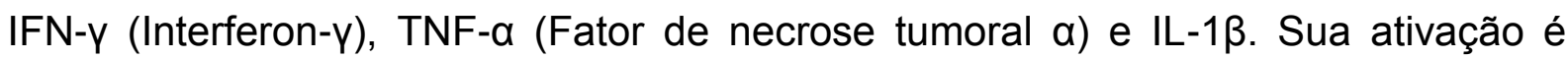
responsável pela liberação de altos níveis de citocinas pró-inflamatórias, incluindo TNF- $\alpha$, STAT3, IL-6, IL-12, IL-1 $\beta$ e IL-23, bem como ativação de óxido nítrico sintase induzível (iNOS), da Nox e liberação de intermediários tóxicos correspondentes, como EROs e de espécies reativas de nitrogênio (ERNs) $(62,63)$.Esse perfil de ativação é considerado neurotóxico e pró-inflamatório (64).

A ativação alternativa ou M2 descreve as atividades anti-inflamatórias e de cicatrização (64). É induzida por citocinas derivadas de células Th2 e pela regulação positiva de receptores de manose. O receptor de manose pode se ligar na superfície de vírus, bactérias e fungos, promovendo sua fagocitose. A ativação por citocinas de células Th2 está envolvida em uma variedade de processos patológicos e fisiológicos, como por exemplo: homeostase, inflamação, alergia, doenças malignas e reparo tecidual (49). Esse tipo de ativação libera altos níveis de citocinas antiinflamatórias como IL-10, IL-4, IL-13, e TGF- $\beta$, e baixos níveis de citocinas próinflamatórias. O tipo M2 pode ser classificado em: M2a, M2b e M2c. O tipo M2a é responsável pela resolução da inflamação e fagocitose. São induzidos pela IL-4, IL13, YM1 (chitinase-like 3), e ARG1 (arginase-1). O tipo M2b é responsável pela degradação de EROs e ERNs liberadas durante a ativação M1 e são induzidas pela exposição combinada de complexos imunes e agonistas TLR ou IL-1R. Esse tipo expressa IL-10 e CCL1. O tipo M2c exerce importante função no reparo e no remodelamento tecidual (cicatrização), bem como na supressão de respostas imunes. São induzidos pela IL-10 e expressam CCL16, CCL17, CCL18, CXCL13, CCR2 e CCR5 (65). 
Apesar da ativação microglial estar relacionada a aspectos deletérios da inflamação crônica no SNC, ela desempenha importantes papéis para a manutenção da homeostase cerebral. Durante o desenvolvimento embrionário, a ativação microglial é fundamental para a poda sináptica (66), a ocorrência da apoptose neuronal (67) e para a retirada de debris celulares. Além disso, é fundamental para a imunidade inata e defesa imunológica, bem como para algumas funções regulatórias, como: auxilia na orientação de células-tronco neurais para as áreas que apresentam danos celulares (68); exerce influência na diferenciação de célulastronco (68); regula a plasticidade sináptica (69) e promove o suporte neurotrófico (70).

Além disso, a classificação da ativação $M 1$ e $M 2$ vem sendo discutida atualmente, uma vez que essa classificação é importante para definir as atividades da microglia in vitro; entretanto, nos estudos in vivo, existe viés na identificação dos tipos de fenótipos (64). Estudos de transcriptoma mostraram que a ativação é variável e contexto dependente, sendo que em modelos de neurodegeneração, a microglia expressa tanto fatores neurotóxicos quanto neuroprotetores (71).

\subsection{Ativação microglial na DP}

A presença de depósitos de debris relacionados ao envelhecimento, bem como de agregados proteicos e proteínas disfuncionais nas doenças neurodegenerativas leva a ativação das PRRs na microglia (72). Além das PRRs, receptores purinérgicos podem ser ativados por nucleotídeos extracelulares, como ATP e UTP, e por nucleosídeos que são liberados por células danificadas. A ativação da microglia leva a liberação de EROS e ERNs pela Nox, iNOS e mieloperoxidase (72).

A presença de microglia ativada na $\mathrm{SNpc}$ e no estriado em amostras postmortem de pacientes com DP foi primeiro descrita por McGeer e colaboradoes em 1988 (44). Imamura e colaboradores (73) mostraram que microglias positivas para o MHC-II (major histocompatibility complex class II), que são importantes para a apresentação de antígenos para células T CD4+, estão distribuídas pelo sistema nigroestriatal, límbico e cortical de cérebros com DP. Além disso, esses autores verificaram que as microglias ativadas estavam associadas a corpos de Lewy e com neuritos danificados(73). Já o trabalho de Croisier e colaboradores (74) mostrou que não houve uma correlação entre a presença de microglias MHCII positivas e os parâmetros clínicos da doença, porém observou uma correlação negativa entre a 
presença de CD68 e a progressão da DP, sugerindo que o aumento da fagocitose no início da DP está associada à destruição tecidual.

Com relação aos diferentes fenótipos de ativação microglial em amostras cerebrais de DP, um estudo demonstrou aumento de iNOS, ciclo-oxigenase 1 e 2 (COX1 e COX2) em microglias ameboides da SN (75), enquanto outro observou o aumento da expressão de CD23 em microglias da SN de cérebros de indivíduos com DP. Esta proteína é expressa quando há a liberação da citocina IFN-y e potencializada com a presença de IL-1 $\beta$ e TNF- $\alpha$. A expressão de CD23 resulta no aumento da produção de óxido nítrico (NO) gerada a partir da ativação de iNOS, que consequentemente regula a liberação de TNF- $\alpha$ e eleva a presença de ERNs, que são prejudiciais aos neurônios dopaminérgicos (76).

Por outro lado, a análise de diferentes interleucinas no soro ou no fluido cerebroespinal ventricular de indivíduos com DP mostrou um aumento significativo tanto de citocinas anti-inflamatórias (IL-4, IL-12,IL-10) quanto de pró-inflamatórias (IL-1 $\beta$, TNF- $\alpha$, INF- $\gamma$ ) nesses pacientes quando comparados com o grupo controle $(77,78)$.

Baseado nesses achados pode-se observar a dificuldade de definir o papel que os diferentes fenótipos microgliais desempenham na progressão da DP, bem como sugerir que os tipos microgliais coexistem e que algumas alterações no seu perfil podem acelerar o processo de neurodegeneração (79). 
Capítulo 1. Tipos microgliais e os processos de neurodegeneração e neuroproteção: um estudo usando 6-hidroxi-dopamina e animais nocautes para Nox2 


\section{INTRODUÇÃO}

\subsection{NADPH oxidase}

As NADPH oxidases (nicotinamida adenina dinucleotídeo fosfato-oxidase) ou Nox consistem em um grupo de enzimas associadas à membrana plasmática. Elas catalisam a produção de $\mathrm{O}_{2}$ “- pela redução de um elétron de $\mathrm{O}_{2}$, tendo como doador de elétron a NADPH, como pode ser visualizada na equação abaixo:

$$
2 \mathrm{O}_{2}+\mathrm{NADPH} \rightarrow 2 \mathrm{O}_{2}^{-}+\mathrm{NADP}^{+}+\mathrm{H}^{+}
$$

Por sua vez, $\mathrm{O}_{2}{ }^{-\cdots}$ formado pode dismutar, espontaneamente ou através da atividade da SOD, gerando $\mathrm{H}_{2} \mathrm{O}_{2}(80)$. A produção de EROs é fundamental para processos que envolvam fagocitose e sinalização, porém essas espécies podem interagir com biomoléculas como ácidos nucleicos, proteínas, lipídeos e carboidratos, alterando sua estrutura e função e, por conseguinte, gerando danos celulares $(80,81)$.

Foram identificadas 7 isoformas da Nox que são: Nox1, Nox2, Nox3, Nox4, Nox5, Dual oxidase 1 e 2 (Duox1 e Duox2). Cada uma delas apresenta componentes citosólicos, mecanismos de regulação, localização subcelular e distribuição tecidual específicos (80). No sistema nervoso foram identificadas apenas as isoformas Nox1, Nox2, Nox3 e Nox4 (82) sendo que Nox2 e Nox4 são as isoformas mais frequentes em neurônios, microglia e astrócitos (81). As subunidades da Nox localizadas na membrana plasmática são: citocromo $b_{558}$, formada pelas subunidades p22 $2^{\text {phox }}$ e gp9 $1^{\text {phox }}$, enquanto que as localizadas no citoplasma são: $\mathrm{p} 40^{\text {phox }}, \mathrm{p} 47^{\text {phox }}$ e $\mathrm{p} 67^{\text {phox }}$ (Figura 2). Essas subunidades encontram-se separadas fisicamente quando o complexo está no estado inativo. Sob o efeito de algum estímulo, a ativação da proteína $G$ de baixo peso molecular (Rac1 ou Rac2) e a fosforilação de $\mathrm{p} 47^{\text {phox }}$ inicia a migração de processos citoplasmáticos para a membrana plasmática. A fosforilação de p47 $7^{\text {phox }}$ altera a conformação molecular das subunidades citossólicas facilitando o contato físico entre p22 ${ }^{\text {phox }}$ e p47 $7^{\text {phox }}$, bem como entre $p 67^{\text {phox }}$ (subunidade ativadora) e gp9 $1^{\text {phox }}(80,83,84)$. O componente catalítico $\mathrm{gp} 91^{\text {phox }}$ facilita a transferência do elétron do citoplasma até o oxigênio localizado no meio extracelular da membrana plasmática, formando assim EROs. 
A formação de EROs derivada da ativação da Nox e DUOX exerce papéis importantes nas seguintes condições fisiológicas: defesa contra micro-organismos invasores, apoptose, crescimento mitogênico, angiogênese, funções endócrinas e modificações oxidativas da matriz extracelular e/ou outras proteínas extracelulares (84). Assim, mutações ou regulação anormal dessas enzimas podem estar associadas à causa de condições patológicas como câncer, aterosclerose, defeitos no sistema imune e condições inflamatórias (84). Alguns estudos verificaram a superativação dessa enzima em doenças neurodegenerativas como na DA e DP, o que leva a um desequilíbrio redox, e consequentemente a danos celulares $(80,83)$.

Figura 2. Mecanismo de ativação das subunidades da enzima Nox e a formação de EROs.

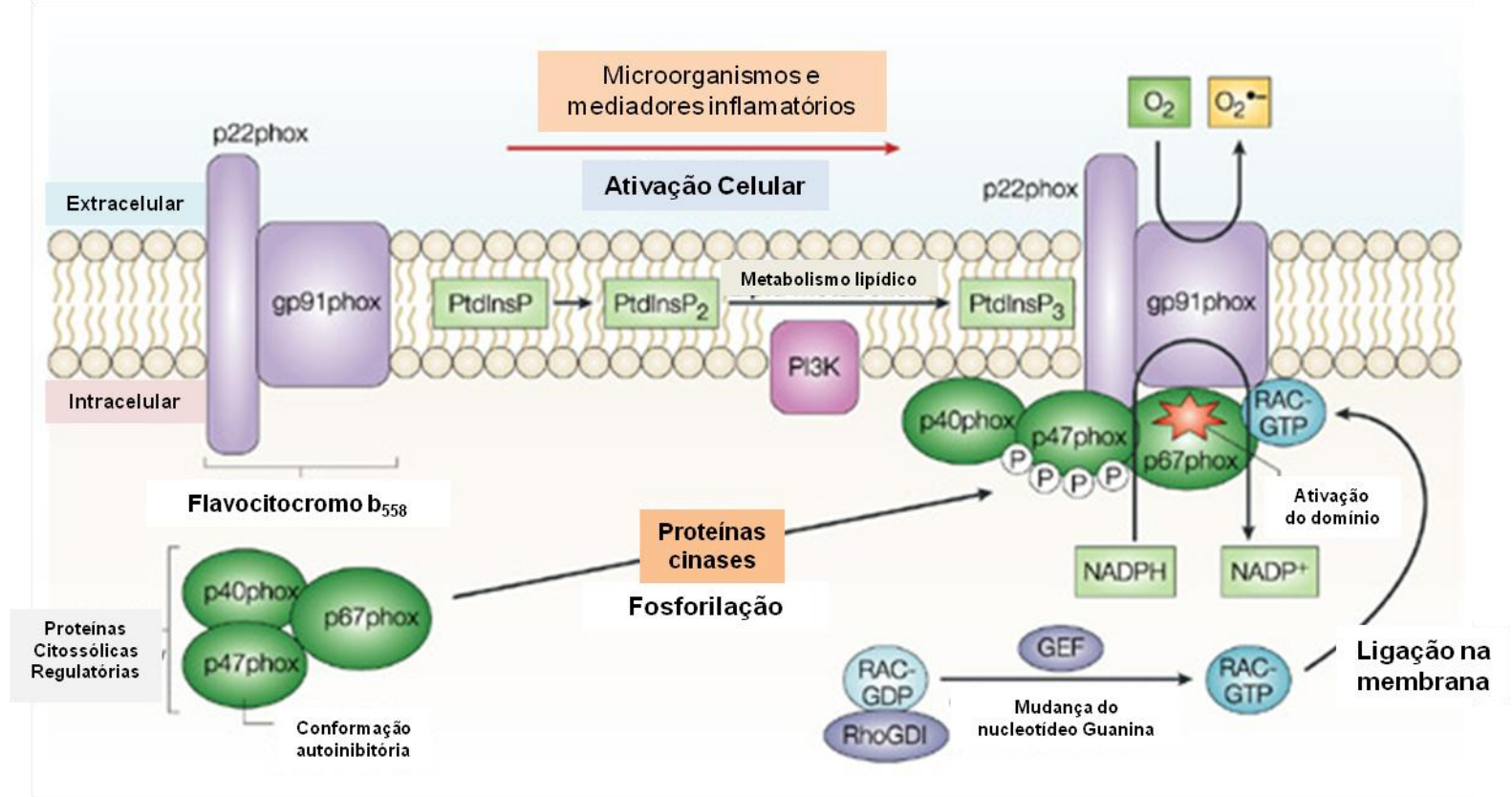

A ativação do complexo enzimático da Nox depende de três fatores para ocorrer, que são: fosforilação da subunidade p47 phox o metabolismo lipídico e a ativação de RAC-GTP. A fosforilação da região auto-inibitória da p47 phox altera a conformação estrutural das subunidades citossólicas, permitindo que ocorra a ligação entre p67 ${ }^{\text {phox }}$ e gp $91^{\text {phox }}$, bem como facilita a conexão entre $\mathrm{p} 47^{\text {phox }}$ com $\mathrm{p} 22^{\text {phox }}$. Por isso, $\mathrm{p} 47^{\text {phox }}$ é conhecida como a subunidade organizadora do complexo. Já o metabolismo lipídico é fundamental para a ligação de domínios da $\mathrm{p} 47^{\text {phox }}$ e da $\mathrm{p} 40^{\text {phox }}$ na membrana. Quando o complexo se encontra inativo, RAC-GDP está acoplada com o inibidor de dissociação RhoGDP (RhoGDI), fazendo com que essa molécula permaneça no citossol. A ativação da troca de fatores ligado ao GTP resulta na mudança conformacional de RAC que promove a dissociação com RhoGDI e a posterior ligação com um domínio da p67 $7^{\text {phox }}$, auxiliando na ativação do complexo.

Fonte: Figura modificada de (84). 
A Nox2 foi primeiramente descrita em neutrófilos e macrófagos, sendo, portanto, conhecida como NADPH oxidase fagocítica pela importante função no processo de defesa contra micro-organismos invasores. Além disso, foram identificados níveis de expressão proteica dessa enzima em células não fagocíticas, como por exemplo, neurônios, cardiomiócitos, hepatócitos e células endoteliais (80). Nos neurônios hipocampais, foi relatado um enriquecimento de $\mathrm{p} 67^{\text {phox }}$ e gp $91^{\text {phox }}$ nos sítios sinápticos e sugerido que a Nox2 é a principal fonte de $\mathrm{O}_{2}{ }^{*}$ necessária para a formação da memória e de LTP (85).

Como a microglia é a principal célula fagocítica do SNC, Nox2 está expressa nessa célula, porém seus níveis variam de acordo com o seu estado fenotípico, apresentando-se em baixos níveis no estado de repouso e em altos níveis quando a célula está ativada (86). Na microglia e nos macrófagos, a Nox2 encontra-se na membrana plasmática no estado de repouso, sendo distribuída internamente em vesículas quando ocorre a sua ativação (87). Em condições fisiológicas normais, a produção de EROs via Nox2 pela microglia exerce um papel fundamental nas fases iniciais do desenvolvimento do cerebelo, uma vez que $\mathrm{O}_{\mathrm{O}_{2}}{ }^{-*}$ formado induz $\mathrm{O}$ processo de apoptose nas células de Purkinje que apresentam caspase 3 ativada, resultando assim, na morte destas e a posterior fagocitose dos debris celulares pela microglia (67). Além disso, um estudo recente mostrou que a Nox2 promove a quimiotaxia da microglia e sua infiltração na zona subventricular telencefálica caudal durante os estágios P0 e P3 de camundongos, sendo, portanto, fundamental na migração e distribuição da microglia nas fases iniciais (88).

\subsection{Nox2 apresenta papel modulador na resposta microglial durante a DP}

O cérebro consiste em um dos órgãos mais afetados pelo dano causado pelo estresse oxidativo, uma vez que apresenta altos níveis de íons metálicos, como o cobre e ferro, altos níveis de ácidos graxos poliinsaturados oxidáveis e pelo fato dos neurônios serem células pós-mitóticas com relativa restrição de reposição celular (89).

A resposta neuronal frente aos estímulos estressantes desencadeados pela condição neurodegenerativa varia de acordo com a vulnerabilidade seletiva da população neuronal envolvida, ou seja, populações de neurônios diferentes apresentam sensibilidade distinta frente ao estresse que provoca a morte celular. Alguns dos fatores que influenciam na vulnerabilidade seletiva dos neurônios são: a 
alta produção intrínsica de estresse oxidativo, a alta demanda por moléculas sinalizadoras como EROs/ERNs, alta atividade de fatores transcricionais relacionados à resposta inflamatória crônica, baixa produção de energia e disfunção mitocondrial. Além disso, esses neurônios são deficientes no reparo de danos ao DNA, apresentam hiperatividade do glutamato e disregulação da sinalização por $\mathrm{Ca}^{2+}$ (89). As células gliais, principalmente a microglia, contribuem para a vulnerabilidade neuronal, uma vez que sua ativação crônica frente ao estresse inflamatório produz altos níveis de EROs/ERNs e outros mediadores neurotóxicos (89).

Evidências apontam que a microglia altera seu estado ativado de M2 para M1 em cérebros tanto no processo de envelhecimento quanto na progressão de doenças neurodegenerativas (61), levando ao aumento de citocinas próinflamatórias e de EROs que, consequentemente, acarretam o aumento de dano neuronal e a natureza crônica da doença (90). As EROs produzidas pela Nox são mediadoras do processo de mudança da morfologia microglial, da expressão de genes pró-inflamatórios e da regulação positiva de marcadores em resposta ao estímulo imunológico. A Nox encontra-se superativada em doenças neurodegenerativas, indicando a importância da ativação microglial por essa enzima na morte neuronal (90).

Alguns estudos relacionaram o aumento da produção de EROs via Nox2 pela microglia e a neurodegeneração dopaminérgica em modelos de DP (91-94). Wu e colaboradores (92) reportaram um aumento da ativação da Nox2 tanto em amostras humanas de DP quanto em modelo murino com MPTP. No modelo murino, verificaram que a ativação dessa enzima ocorre principalmente em células microgliais e que a ausência da subunidade $\mathrm{gp} 91^{\text {phox }}$ em camundongos nocautes (KO) previne a morte de neurônios dopaminérgicos, principalmente devido ao comprometimento da enzima e consequente redução da formação de $\mathrm{O}_{2}{ }^{\circ-}$, não sendo resultado de prejuízos na função microglial ou em alteração no metabolismo de MPTP (92). A partir de culturas mesencefálicas provenientes de camundongos selvagens (WT) e nocautes (gp91 ${ }^{\text {phox-l-l}}$ ) foi demonstrado que a Nox2 microglial é mediadora do processo neurotóxico da rotenona, um herbicida que provoca a morte neuronal dopaminérgica via inibição de complexos mitocondriais e ativação microglial. Os autores observaram que a rotenona induz a ativação microglial e que a liberação de EROs pela Nox2 é o principal fator de neurotoxicidade (91). 


\subsection{Justificativas e objetivos}

Estudos anteriores verificaram que tanto camundongos gp $91^{\text {phox-/- }}$ submetidos à 6-OHDA, quanto camundongos submetidos a essa droga e tratados com apocinina (inibidor da Nox) apresentaram uma melhora significativa do comportamento rotacional induzido pela apomorfina após a injeção da neurotoxina em relação ao grupo controle. Além disso, a apocinina reduziu o processo de neurodegeneração dopaminérgica induzida pela 6-OHDA na SNpc e da perda de terminais dopaminérgicos no $\mathrm{CPu}$ (93). Já o camundongo gp91 ${ }^{\text {phox-l- }}$ apresentou proteção contra a perda de neurônios dopaminérgicos induzidos pela 6-OHDA na SNpc. Análises imuno-histoquímicas da ativação microglial levaram os autores a sugerir que os animais gp91 ${ }^{\text {phox-l- }}$ apresentaram maior proteção contra a ativação microglial induzida pela 6-OHDA, enquanto que o tratamento com apocinina reduziu a ativação microglial (93). Além disso, os autores sugeriram que a ativação excessiva de Nox2 leva a um desequilíbrio na sinalização redox e consequente aumento de EROs, tornando os neurônios dopaminérgicos mais susceptíveis à morte celular induzida pela 6-OHDA.

Os autores também verificaram que o camundongo gp9 $1^{\text {phox-/- }}$, quando submetido à neurotoxina, apresentava quantidades superiores de células OX42+ quando comparadas com o selvagem (95). Os animais foram, então, expostos a tratamento com a minociclina, uma droga que tem como uma de suas funções inibir a ativação e proliferação de células microgliais. Após o tratamento com minociclina, observou-se que os KO submetidos à 6-OHDA apresentaram maior susceptibilidade ao desenvolvimento da DP em relação aos que não foram tratados com minociclina, bem como apresentaram um aumento significativo de TNFa e da atividade de NF-kB na SN. Isso é uma evidência de que Nox2 exerce um papel importante na modulação da resposta inflamatória induzida por 6-OHDA por meio da via sinalizadora mediada por TNFa/NF-kB (95).

Diante disso, foi proposto analisar o perfil microglial tanto no camundongo WT quanto no KO para a subunidade $\mathrm{gp} 91^{\text {phox }}$ com a finalidade de verificar se a presença de Nox2 modula a ativação microglial, que libera citocinas próinflamatórias levando ao desenvolvimento da DP, enquanto que a ausência desse complexo enzimático reduz o número de microglias ativadas, evitando assim a degeneração dos neurônios dopaminérgicos e o desenvolvimento da doença. Dessa 
forma, este estudo busca compreender o papel da microglia em modelos de processos de neurodegeneração e neuroproteção da DP.

Logo, o estudo tem como objetivo central caracterizar a microglia na $\mathrm{SN}$ e no CPu durante a progressão do modelo unilateral da DP induzido por 6-OHDA no camundongo $\mathrm{gp} 91^{\text {phox-l- }}$. Para isso, foram desenhados os seguintes objetivos específicos:

1. Caracterizar o perfil microglial dos camundongos naïves selvagens e nocautes, com a finalidade de verificar se a ausência da Nox2 influencia no número de microglias e, por conseguinte na sua resposta.

2. Analisar a resposta microglial por meio da quantificação do marcador Iba-1 e iNOS frente ao processo neurodegenerativo causado pela 6-OHDA em dois períodos de tempos distintos, 3 e 15 dias. Comparar os resultados obtidos entre os diferentes genótipos e correlacionar com o teste comportamental.

3. Analisar a expressão gênica de marcadores importantes na modulação microglial em função do tempo pós-cirúrgico, com o intuito de verificar se há diferenças no perfil microglial nos diferentes genótipos durante o processo neurodegenerativo.

4. Analisar o dano do DNA mitocondrial (DNAmt) e nuclear (DNAn) na SN após 15 dias da indução da DP com o intuito de verificar o grau do dano oxidativo gerado a partir da neurotoxina nos dois genótipos. 


\section{METODOLOGIA}

\subsection{Desenho Experimental}

No presente estudo, foram utilizados camundongos machos C57BL/6 selvagens e nocautes para a subunidade gp91 da Nox2 com três meses de idade. Tendo-se em vista que a 6-OHDA não cruza a barreira hemato-encefálica, a neurotoxina foi injetada diretamente no CPu para a indução da DP. Como a injeção da 6-OHDA é realizada unilateralmente, tanto o lado controle (salina) quanto o lado com a lesão (6-OHDA) estão localizados no mesmo animal, não havendo a necessidade de ter um grupo controle com salina nos dois hemisférios. Com isso, os animais foram divididos em 4 grupos, sendo eles: (1) camundongo selvagem naïve; (2) camundongo gp91 $1^{\text {phox-l- }}$ naïve; (3) camundongo selvagem com DP; (4) camundongo gp9 $1^{\text {phox-l- }}$ com DP.

Os grupos naïves foram anestesiados com cloridrato de cetamina e cloridrato de xilazina, e submetidos à perfusão transcardíaca com solução $\mathrm{NaCl} 0,9 \%$, seguida de solução fixadora constituída de paraformaldeído 4\% (PFA). Após a fixação, seguiu-se o protocolo de imuno-histoquímica no CPu e na SN para a marcação dos anticorpos Iba-1 e iNOS com a finalidade de verificar o perfil microglial basal.

Os experimentos envolvendo os grupos com DP estão representados na figura 3 e estão detalhados a seguir:

Figura 3. Desenho experimental da análise do processo neurodegenerativo e do perfil microglial de camundongos C57BI6 e nocautes para Nox2

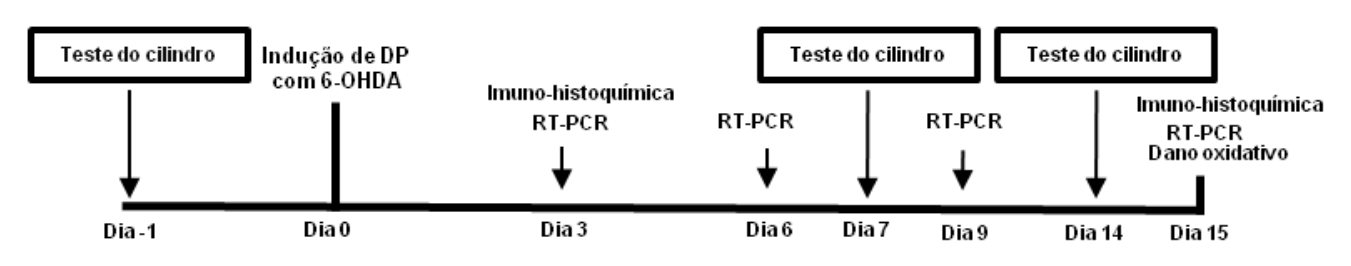

Com relação à análise do perfil neurodegenerativo e microglial após a indução unilateral de DP por meio da técnica de imuno-histoquímica, vinte animais foram separados em dois grupos com dez animais (5 animais por genótipo), sendo que o primeiro foi submetido à perfusão transcardíaca após 3 dias de cirurgia, enquanto 
que o segundo foi submetido ao mesmo procedimento após 15 dias. Os animais pertencentes ao período de 15 dias foram avaliados pelo teste do cilindro nos seguintes dias: 1 dia antes da cirurgia (baseline), 7 dias e 14 dias após a cirurgia.

Para a realização da técnica de PCR em tempo real (RT-PCR), 4 animais de cada genótipo foram submetidos à eutanásia nos seguintes tempos: no terceiro, sexto, nono e décimo quinto dia após a indução com 6-OHDA. Os mesencéfalos foram dissecados e foram realizados os procedimentos específicos da técnica que estão detalhados a seguir.

O dano oxidativo tanto no DNAmt quanto no DNAn da SN foi avaliado em camundongos com 15 dias após a injeção de 6-OHDA (4 animais por grupo de genótipo). Todos os animais que foram sacrificados no décimo quinto dia foram submetidos ao teste do cilindro nos dias indicados.

Os animais foram mantidos em uma sala com ciclo claro/escuro artificialmente controlado de $12 / 12 \mathrm{~h}$ com temperatura constante de $23^{\circ} \mathrm{C}$ e foram alimentados com ração padrão e água ad libitum. Todos os procedimentos foram aprovados pela CEUA-ICB/USP com o número de protocolo de 72/2015.

\subsection{Procedimento cirúrgico}

Os animais foram anestesiados com cloridrato de cetamina (80 mg/Kg, i.p.) e cloridrato de xilazina $(1,2 \mathrm{mg} / \mathrm{Kg})$ e fixados no aparelho estereotáxico. Durante todo o procedimento, os animais foram mantidos em contato com bolsas de água quente para evitar hipotermia. Após a fixação no aparelho, foi injetado um anestésico local (lidocaína+epinefrina) para diminuir o sangramento no local da incisão. Depois disso, foi realizada a craniotomia com auxílio de uma broca de baixa rotação segundo as coordenadas estereotáxicas do CPu, sendo elas: L: $\pm 2,0 \mathrm{~mm}$; AP: $+0,4 \mathrm{~mm}$; V: $-3 \mathrm{~mm}$, tendo como referência o bregma, como indicado no atlas "The mouse brain in stereotaxic coordinates" por George Paxinos (96). Após a craniotomia, foi injetado com Hamilton Neuros Model 75RN (\#65460-02) no hemisfério direito, $5 \mu \mathrm{g}$ de 6OHDA diluída em solução de $\mathrm{NaCl}$ 0,9\% com 0,3\% de ácido ascórbico (veículo) com o intuito de evitar a oxidação da droga. No hemisfério esquerdo, foi injetado o veículo. A 6-OHDA foi administrada no próprio corpo do CPu com a finalidade de efetuar uma lesão retrógrada dos neurônios nigroestriatais (24). Finalizada a microinjeção, a pele foi suturada e os animais mantidos em caixas individuais com bolsas de água quente próximas ao corpo para recuperação da anestesia. Após a 
recuperação, os animais foram reagrupados e monitorados diariamente para a certificação da melhora pós-operatória.

\subsection{Teste do cilindro}

Esse teste tem como objetivo avaliar movimentos espontâneos durante a exploração do animal e o uso assimétrico do membro anterior (97). Tem sido utilizado para avaliar tanto o dano causado pela injeção unilateral de 6-OHDA no CPu (98) quanto para avaliar alguma intervenção após o dano unilateral causado (99). Além disso, apresenta como vantagens os seguintes aspectos: a facilidade de ser avaliado, a confiabilidade, a ausência de uso de drogas dopaminérgicas e a acurácia em detectar um amplo espectro de degeneração tanto em estados crônicos quanto agudos (100).

O teste do cilindro foi realizado nos seguintes períodos: 1 dia antes da cirurgia, 7 dias e 14 dias após a cirurgia e a metodologia foi feita de acordo com Scharllet e colaboradores (100). Inicialmente, os camundongos foram habituados à sala de comportamento por 30 min e colocados em um cilindro transparente de Plexiglas com $25 \mathrm{~cm}$ de altura e $12 \mathrm{~cm}$ de diâmetro. Um espelho foi posicionado atrás do cilindro em um ângulo que favorecesse a visualização dos membros anteriores utilizados na exploração do animal, quando este estivesse de costas para a câmera. A exploração do animal no cilindro foi gravada por 5 minutos e a quantificação e discriminação dos membros anteriores utilizados para tocar as paredes foi realizada por meio do recurso de slow motion da câmera.

A partir da quantificação do uso dos membros anteriores esquerdo e direito, independentemente e concomitantemente, foi calculada a porcentagem da exploração realizada com o membro contralateral à lesão (esquerdo). Os resultados estão apresentados no gráfico como média \pm erro padrão médio (SEM).

\subsection{Marcação retrógrada de neurônios da substância negra com Fluoro-Gold}

A marcação retrógrada de neurônios da SNpc, utilizando o marcador fluorescente Fluoro-Gold (Sigma; 223769-64-0, St.Louis, MO), teve como finalidade padronizar as coordenadas estereotáxicas. A cirurgia foi realizada de acordo com o tópico 2.2., sendo que foi aplicado no CPu $1 \mu \mathrm{L}$ de uma solução de $2 \%$ de FluoroGold. Após o período de 7 dias, o animal foi submetido à perfusão transcardíaca 
como descrito a seguir no tópico 2.5. O encéfalo foi cortado em micrótomo deslizante de congelamento na espessura de $30 \mu \mathrm{m}$ e os cortes foram incubados com anticorpo contra tirosina hidroxilase (TH) diluído a 1:2000 em solução de Triton $\mathrm{X}-100$ a 0,3\% em tampão fosfato (PB) 0,1M durante 14 horas. Depois, os cortes foram lavados 3 vezes por 10 minutos em PB 0,1M e incubados por 2 horas com o anticorpo secundário marcado com FITC dirigido contra a IgG de camundongo. Em seguida, foram lavados novamente por 3 vezes e colocados em lâminas gelatinizadas, que por sua vez, foram cobertas com glicerol, tampão carbonato e lamínulas. Depois de secas, foram analisadas no microscópio para fluorescência. Essa dupla marcação tem como objetivo verificar se o Fluoro-Gold marcou os neurônios dopaminérgicos da SNpc.

\subsection{Imuno-histoquímica (Imunoperoxidase)}

Os animais foram anestesiados com cetamina e xilazina, e submetidos à perfusão transcardíaca com solução de $\mathrm{NaCl} 0,9 \%$, seguida de solução fixadora constituída de PFA 4\% dissolvido em tampão PB 0,1 M (pH 7,4). Após a perfusão, os encéfalos foram coletados e armazenados em PFA por 4 horas e depois desse período, o material foi transferido para uma solução citoprotetora de sacarose a $30 \%$ em PB. Após 48 horas, os tecidos foram cortados em uma espessura de $30 \mu \mathrm{m}$ em um micrótomo deslizante de congelamento. Cortes de SN e CPu foram selecionados e submetidos à metodologia de peroxidase com anticorpos específicos de interesse do estudo, dentre eles: iNOS (óxido nítrico sintase induzível - BD Biosciences, 610329, diluição: 1:500) para marcar microglia pró-inflamatória; TH (tirosina hidroxilase - Chemicon, Millipore, MAB5280, diluição: 1:2000) para marcar os neurônios dopaminérgicos e lba-1 (Molécula 1 adaptadora ligante de cálcio ionizado, Abcam, ab5076, diluição: 1:1000), marcador de microglia.

Os cortes foram lavados em tampão PB por três vezes de 10 minutos e incubados com os anticorpos primários descritos acima em PB com 0,3\% de Triton $\mathrm{X}-100$ e $5 \%$ de soro do animal que foi produzido o secundário. Após um período de 14 a 18 horas à temperatura ambiente, os cortes foram novamente lavados em tampão PB e incubados por duas horas com anticorpo secundário biotinilado contra o soro do animal no qual foi feito o anticorpo primário. Após uma nova série de lavagens, os cortes foram incubados por mais duas horas com o complexo avidinabiotina-peroxidase, numa solução de Triton X-100 0,3\% em PB 0,1 M com 0,4 M de 
$\mathrm{NaCl}$. Após outra série de lavagens, os cortes foram imersos em um meio contendo 3-3' diaminobenzidina (DAB) 0,05\% em PB 0,1 M por 5 minutos. Em seguida, foi acrescentada uma solução de $\mathrm{H}_{2} \mathrm{O}_{2}$ a $0,1 \%$ em água destilada, mantendo-se os cortes nessa solução até que a imunorreatividade desejada fosse atingida e evidenciada com o desenvolvimento de coloração marrom. Os cortes foram removidos da solução com DAB e imersas em tampão PB 0,1 M.

Com a finalidade de remover o excesso de reagente, os cortes foram submetidos a uma nova série de lavagens em tampão PB 0,1 M e colocados sobre lâminas de vidro gelatinizadas, as quais foram colocadas em placa quente. Depois que as lâminas ficaram secas, elas foram hidratadas em água destilada por 1 minuto, banhadas em solução de tetróxido de ósmio $0,1 \%$ por 30 segundos, desidratadas por uma série de alcoóis em concentrações crescentes, clareadas com xilol e cobertas com lamínulas, tendo como meio de montagem o Permount.

\subsection{Genotipagem dos camundongos gp9 $1^{\text {phox--/ }}$}

Os animais nocautes foram anestesiados com isofurano, um anestésico inalatório, com a finalidade de seccionar $2 \mathrm{~mm}$ da cauda para realizar a genotipagem, e desse modo, garantir que os animais eram nocautes para o gene CYBB. Cada animal foi identificado com furos na orelha e durante o procedimento os materiais utilizados foram limpos com etanol 70\% para evitar contaminação. Após a coleta de fragmento das caudas, o tecido foi incubado com $\mathrm{NaOH} 50 \mathrm{mM}$ a $95^{\circ} \mathrm{C}$ por 10 minutos. Depois desse período, foram adicionado $50 \mu \mathrm{L}$ de Tris- $\mathrm{HCl}, \mathrm{pH} 6,8$ a $1 \mathrm{M}$ e as amostras foram centrifugadas a $12.000 \mathrm{rpm}$ por 15 minutos a $4^{\circ} \mathrm{C}$. Em seguida, as amostras foram armazenadas em freezer a $-20^{\circ} \mathrm{C}$.

A técnica de PCR foi realizada conforme o protocolo do The Jackson Laboratory para o alelo Cybb $^{\text {tm1Din }}$. Os primers utilizados estão descritos na tabela abaixo (tabela 1): 
Tabela 1: Sequência de primers utilizados na genotipagem dos nocautes

\begin{tabular}{lcc}
\hline Primer & \multicolumn{1}{c}{ Sequência 5' $\rightarrow 3^{\prime}$} & $\begin{array}{c}\text { Tipo de } \\
\text { amplificação }\end{array}$ \\
\hline olMR0517 & AAG AGA AAC TCC TCT GCT GTG AA & Comum \\
olMR0518 & CGC ACT GGA ACC CCT GAG AAA GG & Selvagem \\
olMR0519 & GTT CTA ATT CCA TCA GAA GCT TAT CG & Mutante \\
\hline
\end{tabular}

A reação de $\mathrm{PCR}$ foi realizada no gelo, utilizando os seguintes reagentes na concentração final: $1 \mathrm{X}$ AB PCR Bufferll, $2,5 \mathrm{mM} \mathrm{MgCl}$, $0,2 \mathrm{mM}$ dNTP, $1 \mu \mathrm{M}$

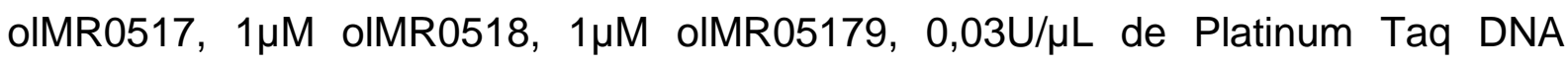
polimerase e $10 \mu \mathrm{L}$ de DNA. Em seguida, as amostras foram incubadas no termociclador de acordo com a programação abaixo (Tabela 2):

Tabela 2: Ciclo do termociclador

\begin{tabular}{|c|c|c|c|}
\hline Passo & $\begin{array}{l}\text { Temperatura } \\
\left({ }^{\circ} \mathrm{C}\right)\end{array}$ & Tempo & Observações \\
\hline 1 & 94 & 3 minutos & \\
\hline 2 & 94 & 20 segundos & $-0,5^{\circ} \mathrm{C}$ por ciclo \\
\hline 3 & 64 & 30 segundos & \\
\hline 4 & 72 & 35 segundos & $\begin{array}{l}\text { Repetir os passos } 2 \text { a } 4 \text { por } 12 \\
\text { ciclos }\end{array}$ \\
\hline 5 & 94 & 20 segundos & \\
\hline 6 & 58 & 30 segundos & \\
\hline 7 & 72 & 35 segundos & $\begin{array}{l}\text { Repetir os passos } 5 \text { a } 7 \text { por } 25 \\
\text { ciclos }\end{array}$ \\
\hline 8 & 72 & 2 minutos & \\
\hline 9 & 10 & & Hold \\
\hline
\end{tabular}

Após a incubação no termociclador, as amostras foram armazenadas a $-20^{\circ} \mathrm{C}$. Com a finalidade de visualizar os produtos da reação de PCR, foi preparado um gel de agarose a $3 \%$ em Tris/Borato/EDTA (TBE) $1 \mathrm{X}$ com $10 \mu \mathrm{L}$ de SYBR Safe DNA gel stain (\#533102, Invitrogen). No gel, foram aplicados $20 \mu \mathrm{L}$ do padrão e $12 \mu \mathrm{L}$ de cada amostra (10 $\mu \mathrm{L}$ da reação de PCR e $2 \mu \mathrm{L}$ de Blue Green loading dye). A 
eletroforese foi realizada em tampão TBE $1 \mathrm{X}$ em $100 \mathrm{~V}$ por 40 minutos e em seguida o gel foi fotografado em um transiluminador.

De acordo com o protocolo do laboratório The Jackson Laboratory, os tamanhos das bandas dos produtos amplificados são: 240pb para os animais selvagens; 195bp para os mutantes; 240pb e 195pb para os heterozigotos.

\subsection{Extração de RNA para Real Time PCR e verificação da integridade de RNA}

Os animais submetidos ao procedimento cirúrgico foram sacrificados por decapitação nos seguintes períodos: 3, 6, 9 e 15 dias após a indução do modelo de DP. O mesencéfalo foi extraído e congelado em nitrogênio líquido para a análise da expressão gênica em função do processo neurodegenerativo. A extração de RNA foi realizada de acordo com o protocolo do TRIzol (\#15596, Life Technologies) e todos os procedimentos foram realizados com soluções estéreis e livres de RNAse.

O volume de $800 \mu \mathrm{L}$ de TRIzol foi adicionado ao tecido para promover a lise e facilitar a homogeneização por meio do sonicador. Após esse procedimento, o tecido foi centrifugado a $12.000 \mathrm{~g}$ por 10 minutos a $4^{\circ} \mathrm{C}$ e seu sobrenadante foi coletado e transferido para novo tubo. A amostra foi incubada por 5 minutos em temperatura ambiente para promover a dissociação dos complexos núcleos-proteicos, e posteriormente, foi adicionado $250 \mu \mathrm{L}$ de clorofórmio. A solução foi incubada por 3 minutos a temperatura ambiente, homogeneizada e submetida à centrifugação a $12.000 \mathrm{~g}$ por 15 minutos a $4^{\circ} \mathrm{C}$. Nessa etapa, a amostra foi separada em uma fase inferior vermelha de fenol-clorofórmio, uma fase intermediária e uma fase superior transparente e aquosa, que contém o RNA. Essa fase superior foi transferida cuidadosamente para novo tubo e foram adicionados $500 \mu \mathrm{L}$ de isopropanol e $0,7 \mu \mathrm{L}$ de glicogênio (\#10814-010, Invitrogen) para facilitar a precipitação do RNA, sendo em seguida armazenadas em freezer $-20^{\circ} \mathrm{C}$ por 12 a 14 horas.

Após esse período, os tubos foram mantidos em temperatura ambiente por 10 minutos e em seguida foram centrifugados a $12.000 \mathrm{~g}$ por 10 minutos a $4^{\circ} \mathrm{C}$. $\mathrm{O}$ sobrenadante foi descartado, enquanto que o pellet foi ressuspendido em $1 \mathrm{~mL}$ de etanol $100 \%$ e centrifugado a $7.500 \mathrm{~g}$ por 5 minutos a $4^{\circ} \mathrm{C}$. Novamente, o pellet foi lavado em $1 \mathrm{~mL}$ de etanol $75 \%$ e submetido à centrifugação de $7.500 \mathrm{~g}$ por 10 minutos a $4^{\circ} \mathrm{C}$. O pellet proveniente dessa centrifugação ficou secando por cerca de 10 minutos a temperatura ambiente para evitar a presença de resquícios de etanol no tubo, sendo, em seguida, ressuspendido em $20 \mu \mathrm{L}$ de $\mathrm{H}_{2} \mathrm{O}$ DEPEC e incubado a 
$55^{\circ} \mathrm{C}$ por 15 minutos. O RNA foi quantificado no Nanodrop 2000c (Thermo scientific) e foram analisadas as relações 260/280 e 260/230 com a finalidade de garantir a pureza das amostras.

As amostras extraídas de RNA foram submetidas à eletroforese em gel de agarose a $1 \%$ para a verificação da sua integridade. Foram aplicados $400 n g$ das amostras com Blue Green loading dye no gel de agarose a 1\% em TBE 1X com 22,6 $\mu \mathrm{L}$ de SYBR Safe DNA gel stain (\#533102, Invitrogen). A eletroforese foi realizada em tampão TBE 1X em $100 \mathrm{~V}$ por 40 minutos, e em seguida o gel foi fotografado em um transiluminador de luz ultravioleta (UV). A integridade do RNA é definida pela observação das bandas $28 \mathrm{~S}$ e $18 \mathrm{~S}$.

\subsection{Síntese de cDNA}

A síntese de cDNA foi realizada conforme as instruções do fabricante do kit da Promega \#A3500. A quantidade de $1 \mu \mathrm{g}$ das amostras de RNA foi incubada no termociclador a $70^{\circ} \mathrm{C}$ por 10 minutos, depois foram resfriadas a $4^{\circ} \mathrm{C}$ e, em seguida, foram adicionados os seguintes reagentes com suas respectivas concentrações finais: 1X Reverse Transcription Buffer; $1 \mathrm{mM}$ de dNTP; $5 \mathrm{mM}$ de $\mathrm{MgCl}_{2} ; 1 \mathrm{U} / \mu \mathrm{l}$ Recombinant RNasin Ribonuclease Inhibitor; 15U AMV Reverse Transcriptase; $0,5 \mu \mathrm{g}$ Oligo $(\mathrm{dT})_{15}$ Primer. Após a adição dos reagentes, as amostras foram incubadas a $42^{\circ} \mathrm{C}$ por 1 hora, seguido de aquecimento a $95^{\circ} \mathrm{C}$ por 5 minutos. $\mathrm{O}$ produto dessa reação foi armazenado em freezer $-20^{\circ} \mathrm{C}$.

2.9. Padronização da quantidade de cDNA utilizada para a reação de $P C R$ em tempo real (RT-PCR)

Os primers utilizados na reação de RT - PCR estão descritos na tabela abaixo (tabela 3): 
Tabela 3. Sequência de primers utilizados na reação de PCR em tempo real

\begin{tabular}{lll}
\hline Gene & \multicolumn{1}{c}{ Forward } & \multicolumn{1}{c}{ Reverse } \\
\hline iNOS & GTT CTC AGC CCA ACA ATA CAA GA & GTG GAC GGG TCG ATG TCAC \\
Arginase-1 & GTG AAG AAC CCA CGG TCT GT & GCC AGA GAT GCT TCC AAC TG \\
CD206 & CTC TGT TCA GCT ATT GGA CGC & CGG AAT TTC TGG GAT TCA GCT TC \\
CD86 & CTG GAC TCT ACG ACT TCA CAA TG & AGT TGG CGA TCA CTG ACA GTT \\
TH 1 & TTG GAG GCT GTG GTA TTC G & TGG CTT CAA ATG TCT CAA AC \\
TH2 & TTC TCT GAC CAG GCG TAT C & CCT CCT TCC AGG TAG CAA T \\
GAPDH & GTG CAG TGC CAG CCT CGT & CAG GCG CCC AAT ACG GCC \\
B2M & AAT GTG AGG CGG GTG GAA CTG & CAT GGC TCG CTC GGT GAC C
\end{tabular}

Foram realizadas curvas de quantidade de cDNA para cada primer, com a finalidade de definir a quantidade ideal para se verificar diferenças de expressão gênica entre os grupos selvagem e nocaute. Para cada reação, foram utilizados 400ng de cada primer e 1x do SYBR@ Green PCR Master Mix (\#4309155, Applied Biosystems).

\subsection{PCR de longa extensão}

Essa técnica baseia-se no princípio de que diferentes tipos de lesões no DNAmt e no DNAn bloqueiam a progressão da DNA polimerase ou reduzem sua processividade na amplificação de um fragmento longo, resultando assim, na diminuição dos produtos amplificados (101).

Para a realização dessa técnica foram utilizadas amostras congeladas de SN tanto do lado controle quanto do lado com 6-OHDA de animais WT e KO, cujo sacrifício foi realizado 15 dias após a cirurgia. Inicialmente, amostras de DNA foram extraídas conforme as instruções do fabricante descritas no kit DNeasy Blood and Tissue (Qiagen; \#69054). Após esse processo, as amostras foram quantificadas em Nanodrop 2000c (Thermo scientific) e foram analisadas as relações 260/280 e 260/230 com a finalidade de garantir a pureza das amostras. Depois da quantificação, as amostras de DNA foram diluídas para a concentração de 6ng/ul para serem utilizadas nas reações de PCR.

Os primers utilizados nas reações de PCR de longa extensão estão apresentados na tabela 4 . 
Tabela 4. Primers utilizados na reação de PCR de longa extensão

\begin{tabular}{|c|c|c|}
\hline Descrição & Sequência $5^{\prime} \rightarrow 3^{\prime}$ & Tamanho (pb) \\
\hline \multicolumn{3}{|l|}{ Fragmento curto } \\
\hline mitocondrial & AACCTCCATAGACCGGTGTAAA & \multirow{5}{*}{140} \\
\hline (RNR1) forward & & \\
\hline \multicolumn{2}{|l|}{ Fragmento curto } & \\
\hline \multicolumn{2}{|l|}{ mitocondrial } & \\
\hline (RNR1) reverse & TTTATCACTGCTGAGTCCCGT & \\
\hline \multicolumn{3}{|l|}{ Fragmento curto } \\
\hline nuclear (HPRT) & GCCTGGACTTTGCCCCTAAT & \\
\hline \multicolumn{3}{|l|}{ forward } \\
\hline \multicolumn{3}{|l|}{ Fragmento curto } \\
\hline nuclear (HPRT) & CGCCTTTCCACTCTTCAGGT & \\
\hline \multicolumn{3}{|l|}{ reverse } \\
\hline \multicolumn{3}{|l|}{ Fragmento longo } \\
\hline mitocondrial & GCCAGCCTGACCCATAGCCATAATAT & \\
\hline (XLMT) forward & & 10090 \\
\hline Fragmento longo & GAGAGATTTTATGGGTGTAATGCGG & \\
\hline \multicolumn{3}{|l|}{ mitocondrial } \\
\hline \multicolumn{3}{|l|}{ (XLMT) reverse } \\
\hline \multicolumn{3}{|l|}{ Fragmento longo } \\
\hline \multicolumn{3}{|c|}{ nuclear $\quad(\beta-$ TTGAGACTGTGATTGGCAATGCCT } \\
\hline globina) forward & & 8831 \\
\hline Fragmento longo & & \\
\hline nuclear $\quad(\beta-$ & ССTTTAATGCCCATCCCGGACT & \\
\hline globina) reverse & & \\
\hline
\end{tabular}

Para as reações dos fragmentos curtos, foi utilizado o kit da Taq DNA Polimerase padrão (Invitrogen \#10342-0530), sendo usado 3ng de DNA para a reação mitocondrial e $60 \mathrm{ng}$ de DNA para a reação nuclear. Ambas as reações apresentaram os seguintes reagentes e suas respectivas concentrações finais para um volume final de 50 $\mu \mathrm{L}$ : $1 \mathrm{X}$ Buffer; $0,2 \mathrm{mM}$ de dNTP; $1,5 \mathrm{mM}$ de $\mathrm{MgCl}_{2} ; 0,5 \mu \mathrm{M}$ dos primers e $0,2 \mu \mathrm{L}$ de Taq DNA Polimerase. 
O seguinte programa no termociclador foi realizado para a reação do fragmento

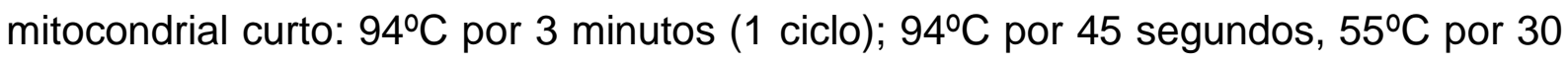
segundos, $72^{\circ} \mathrm{C}$ por 1 minuto (22 ciclos). Já para o fragmento nuclear curto, 0 programa foi: $94^{\circ} \mathrm{C}$ por 3 minutos ( 1 ciclo); $94^{\circ} \mathrm{C}$ por 45 segundos, $56^{\circ} \mathrm{C}$ por 30 segundos, $72^{\circ} \mathrm{C}$ por 1 minuto (31 ciclos).

Com relação aos fragmentos longos, foi utilizado o kit AccuPrime Taq DNA Polymerase High Fidelity (Invitrogen \#12346086), em que a DNA polimerase é capaz de amplificar acima de $16 \mathrm{~kb}$. Nessas reações, 30ng de DNA foi usado no fragmento longo nuclear e 120ng no longo mitocondrial, sendo que para cada reação foram obtidas as seguintes concentrações finais dos reagentes para um volume de $50 \mu \mathrm{L}$ : 1X Buffer II; 0,2 $\mu \mathrm{M}$ dos primers e 0,2 $\mu \mathrm{L}$ de Taq DNA Polimerase.

Para a reação do fragmento longo mitocondrial, o seguinte programa foi usado no termociclador: $94^{\circ} \mathrm{C}$ por 30 segundos ( 1 ciclo); $94^{\circ} \mathrm{C}$ por 30 segundos, $56^{\circ} \mathrm{C}$ por 30 segundos, $68^{\circ} \mathrm{C}$ por 18 minutos (28 ciclos). Já para a reação do fragmento longo nuclear, o programa foi: $94^{\circ} \mathrm{C}$ por 30 segundos ( 1 ciclo); $94^{\circ} \mathrm{C}$ por 30 segundos, $62^{\circ} \mathrm{C}$ por 30 segundos, 68ำ por 15 minutos (33 ciclos).

Com o objetivo de visualizar e quantificar os produtos de amplificação dos fragmentos curtos, $20 \mu \mathrm{L}$ das reações com $4 \mu \mathrm{L}$ de Orange DNA Loading Dye (Thermo \#R0631) foram aplicados em gel de poliacrilamida 10\% não-desnaturante (TBE 1X; Acrilamida/Bis-Acrilamida 19:1) e submetidos a 60V por 2 horas. Usou-se - GeneRuler Low Range DNA Ladder (Thermo \# SM1193) como marcador de tamanho molecular. Para os fragmentos longos, foi aplicado o mesmo volume das reações com o loading em gel de agarose $1 \%$, foi utilizado o marcador de tamanho molecular Lambda DNA/HindIIl e a corrida do gel foi de $100 \mathrm{~V}$ por $2 \mathrm{~h}$.

Após a eletroforese, os géis foram incubados em solução de brometo de etídeo $4 \mu \mathrm{g} / \mathrm{mL}$ por 20 minutos e, em seguida, lavados em água por 5 minutos. Depois de corar os géis, estes foram fotografados em um fotodocumentador e as áreas das bandas foram quantificadas por meio do software ImageJ (NIH - National Institutes of Health). A normalização dos dados foi feita pela divisão da área dos fragmentos longos pelos respectivos fragmentos curtos. 


\subsection{Análise de resultados}

A imunorreatividade foi analisada em microscópio de luz e quantificações da marcação foram realizadas com o programa ImageJ $(\mathrm{NIH})$. Para análise semiquantitativa das regiões de interesse, imagens digitais ( 5 cortes/região/animal) foram capturadas em microscópio óptico (E1000, Nikon) acoplado a uma câmera digital e ao programa Nikon Imaging Software ACT-U. Os dados de TH na SNpc foram obtidos através da utilização da ferramenta "Cell Counter". A análise foi feita no lado controle e experimental de cada corte do encéfalo, e com os valores obtidos foi realizado um cálculo da porcentagem de células TH-positivas no hemisfério experimental em relação ao controle considerado como $100 \%$. Os dados de TH no $\mathrm{CPu}$ foram obtidos por densidade integrada de ambos os hemisférios, enquanto que a quantificação de Iba-1 e de iNOS foi realizada por densidade integrada limitada pela ferramenta threshold. Com os valores das médias efetuou-se uma razão (média da densidade integrada do hemisfério experimental/ média da densidade integrada do hemisfério controle), e, assim, obteve-se um valor final para cada animal.

Antes das análises estatísticas, foi verificada a homogeneidade das variâncias pelo teste de Levene e a normalidade através do teste de Shapiro-Wilk. Caso os dados não apresentassem uma distribuição normal, estes foram transformados até atingir a normalidade. Se mesmo após a transformação, não fosse obtida a normalidade, utilizou-se o teste não-paramétrico correspondente. Após o ajuste desses parâmetros, os dados foram avaliados a partir do teste-t para medidas pareadas quando analisado lado controle e experimental do mesmo animal e não pareado quando analisados animais selvagens e nocautes. Para a comparação dos diferentes períodos após a cirurgia, foi realizado o teste ANOVA de duas vias com pós-teste de Bonferroni. No caso do teste do cilindro, foi conduzido o teste ANOVA de duas vias com medidas repetidas e com o pós-teste de Bonferroni. Para todos os testes, o nível de significância assumido foi de $p \leq 0,05$. Os resultados estão representados nos gráficos na forma de média \pm erro padrão da média. 


\section{RESULTADOS}

3.1. Genotipagem dos camundongos nocautes para a subunidade gp $91^{\text {phox }}$

Com o objetivo de certificar a ausência do gene CYBB ligado ao cromossomo $\mathrm{X}$ nos animais utilizados e nos casais da colônia, foi realizada a genotipagem de acordo com as recomendações da The Jackson Laboratory, sendo que os tamanhos dos produtos amplificados para cada animal são: 240pb para os selvagens; 195pb para os mutantes; 240pb e 195pb para os heterozigotos.

A partir dos resultados apresentados na figura 4, observou-se que os animais utilizados na imuno-histoquímica do ponto de 15 dias são $\mathrm{KO}$ para o gene $C Y B B$, uma vez que apresentam apenas a banda de 195pb (painel A, Figura 4). Um animal selvagem foi utilizado como controle positivo, apresentando apenas a banda de $240 \mathrm{pb}$.

Da mesma forma, os casais que compõem a colônia de KO também apresentaram apenas a banda de $195 \mathrm{pb}$, indicando que os cruzamentos estão ocorrendo entre animais homozigotos (fêmeas) e hemizigotos (machos), o que impossibilita a geração de fêmeas heterozigotas ou machos selvagens (painel B da figura 4). 
Figura 4. Representação de um gel de agarose de $3 \%$ para a verificação da ausência do gene CYBB nos camundongos gp91 $1^{\text {phox-l- }}$

A.

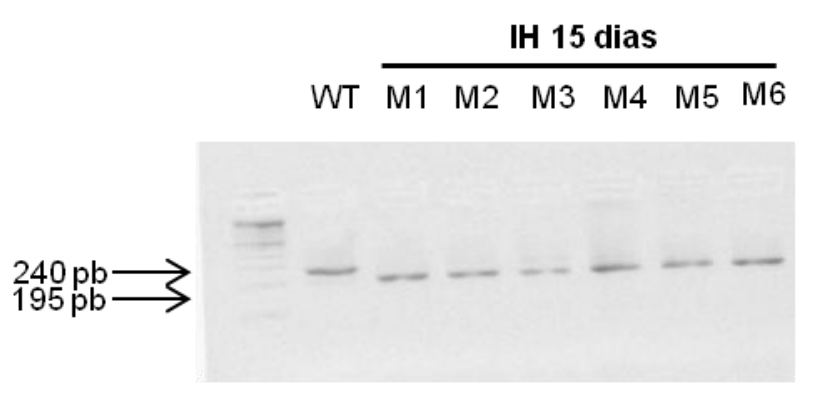

B.

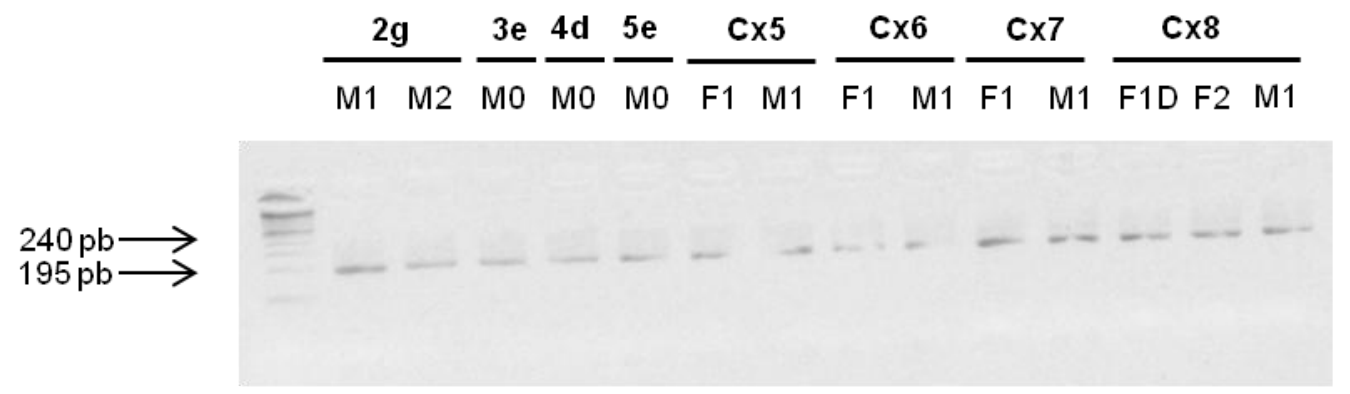

Para cada reação, foram utilizados os primers: olMR0517, olMR0518 e olMR0519. A. Verificação da amplificação apenas do produto com 195pb nos animais utilizados para a técnica de imuno-histoquímica $(\mathrm{IH})$, o que confirma a ausência do gene CYBB. No camundongo selvagem (WT) foi verificada apenas a banda de 240pb. B. Confirmação de colônias com fêmeas homozigotas e machos hemizigotos para o gene $C Y B B$. M camundongo macho seguido da numeração correspondente na caixa de identificação; $F$ camundongo fêmea seguida da numeração correspondente; WT - camundongo selvagem; IH - imuno-histoquímica; Cx - caixa seguida do número de identificação; $2 \mathrm{~g}, 3 \mathrm{e}, 4 \mathrm{~d}, 5 \mathrm{e}-$ números e letras das caixas dos animais.

3.2. Perfil microglial dos camundongos naïves selvagens e nocautes (gp91 phox $^{-1-}$ )

De acordo com os resultados de Hernandes e colaboradores (95), o camundongo $\mathrm{gp} 91^{\text {phox-l- }}$ apresentou um aumento de células microgliais ativadas quando submetido à neurotoxina para indução de DP. Com o intuito de verificar se esse aumento deve-se a um estado basal mais elevado de células microgliais nos nocautes, foi realizada a marcação no CPu e na SNpc de camundongos naïves com os anticorpos para microglia (Iba-1) e para o fenótipo M1 (iNOS). 
Com relação aos resultados obtidos a partir da quantificação do anticorpo lba1, observou-se que a concentração de microglia tanto no CPu quanto na SNpc dos camundongos $\mathrm{KO}$ naïves foi significativamente superior em relação à dos WT naïves, como pode ser visualizado nas imagens $A-F$ da figura 5 (Teste $t$ não pareado; Para o $\mathrm{CPu}, \mathrm{p}=0,041 ; \mathrm{t}=-2,49$; Para a $\mathrm{SNpc}, \mathrm{p}=0,044 ; \mathrm{t}=-2,44)$. Com isso, pode-se afirmar que os KO apresentaram maior densidade de células Iba-1+ no seu estado basal nas duas regiões analisadas.

Assim como observado para a marcação com lba-1, os $\mathrm{KO}$ naïves apresentaram uma densidade de células positivas para iNOS significativamente superior aos WT no CPu (Teste $t$ não pareado; $p=3 \times 10^{-6} ; t=-32,49$ ) e na SNpc (Teste $t$ não pareado; $p=8,11 \times 10^{-7} ; t=-16,25$ ), como pode ser viasualizado nas imagens G-M da figura 5. Com base nesses dados, os $\mathrm{KO}$ apresentaram microglias no seu estado basal com ativação da enzima iNOS, e possivelmente, mais propensas a liberar NO. 
Figura 5. Densidade integrada das células marcadas com lba-1 e iNOS no CPu e na SNpc de camundongos selvagens e nocautes naïves

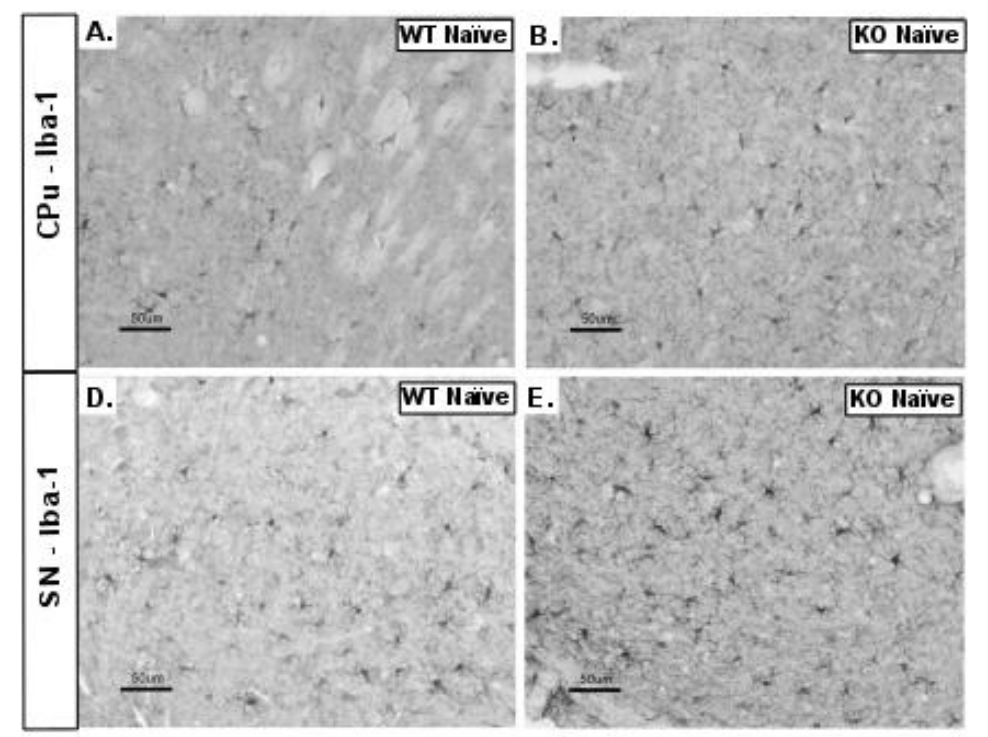

c.
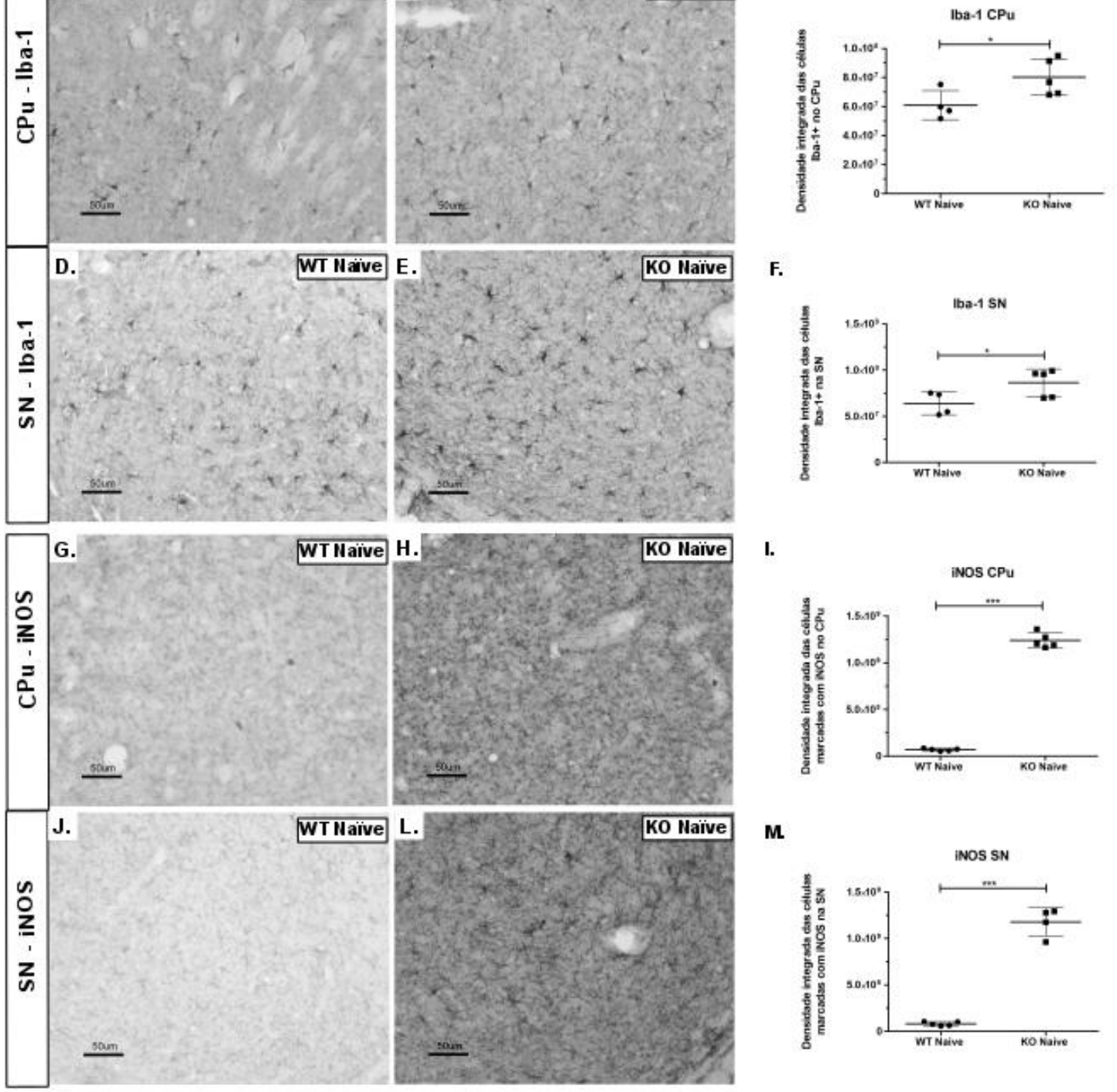

$\mathbf{M}$

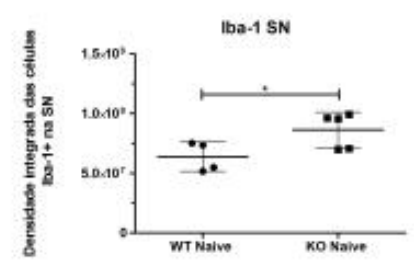

1.

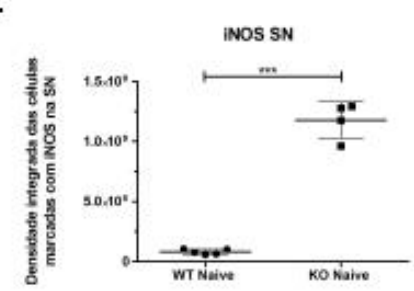

A. Células positivas para lba-1 no estriado de WT naïves. B. Número superior de microglias ativadas no estriado de camundongos gp9 $1^{\text {phox-l- }}$ naïve quando comparado com 0 do controle. C. Gráfico que apresenta a média do grupo e as médias de cada animal da marcação de lba-1 no estriado de WT e KO naïves, mostrando um número significativamente maior de células nos nocautes em relação ao selvagem. D. Células lba-1+ na SNpc de WT naïves. E. Aumento da marcação de células lba-1+ na SNpc de KO naïves. F. Gráfico mostrando a diferença significativa entre a marcação de lba-1 entre os WT e KO na SNpc. G. Células positivas para iNOS no estriado de WT naïve. H. Intensidade superior da marcação de iNOS no estriado de gp $91^{\text {phox-l- }}$ naïve quando comparado com o do controle. I. Gráfico que apresenta a média do grupo e as médias de cada animal da marcação de iNOS no estriado de WT e KO naïves, mostrando um número significativamente maior de células positivas nos nocautes em relação ao selvagem. J. Células positivas para iNOS na SNpc de WT naïve. L. Células positivas para iNOS na SNpc de KO naïve. M. Gráfico 
mostrando o aumento de células iNOS+ nos $\mathrm{KO}$ naïves em relação aos selvagens. Esse gráfico apresenta a média \pm erro padrão de 5 cortes de tecido de cada animal, $n=5$. WT naïve - camundongos selvagens naïves; KO naïve - camundongos nocautes naïves.

\subsection{Marcação retrógrada de neurônios dopaminérgicos da substância negra}

A marcação retrógrada dos neurônios dopaminérgicos da SNpc com 0 FluoroGold tem como objetivo verificar se as coordenadas estereotáxicas para a indução da DP estão sendo realizadas de forma correta, garantindo que a 6-OHDA cause a degeneração progressiva e retrógrada das conexões neuronais da via nigroestriatal.

O FluoroGold é um fluoróforo amplamente usado para estudar os circuitos neuronais devido as suas propriedades específicas, sendo elas: (1) Intensa fluorescência e resistência ao decaimento do sinal - análises de micrografias demonstraram o acúmulo de vesículas contendo o FluoroGold tanto no corpo celular quanto nos dendritos em animais com o fluoróforo durante o período de 4 dias e de 4 semanas, confirmando a permanência da intensidade do sinal durante longos intervalos de tempo (102); (2) Ausência de liberação do marcador fluorescente pelas células que o incorporaram - essa característica deve-se ao fato do FluoroGold não atravessar a membrana plasmática, possibilitando que somente as células neuronais que estavam próximas da administração o captassem, bem como garante a duração do sinal; (3) Transporte unidirecional - o mecanismo de ação do FluoroGold ainda não é bem estabelecido, mas algumas evidências sugerem que o transporte retrógrado desse marcador ocorre por meio da sua captação por vesículas endocíticas localizadas nos terminais sinápticos e seu transporte para o corpo celular para que ocorra a degradação. (4) Compatibilidade com outras técnicas de imuno-histoquímica - A permanência do sinal permite a combinação com outros marcadores fluorescentes, que não são excitados com a mesma frequência de onda, ou com outras técnicas como, por exemplo, a imunocitoquímica (102).

Com base nessas evidências, foi realizada uma microinjeção do FluoroGold nas coordenadas referentes a indução de DP e posterior imunofluorescência com o anticorpo para $\mathrm{TH}$, utilizando um anticorpo secundário acoplado com FITC. Essa combinação é possível uma vez que os comprimentos de onda de excitação e emissão dos dois fluoróforos são distintos, sendo que o FluoroGold em meio básico é excitado em $365 \mathrm{~nm}$ (luz UV) e emite fluorescência em $565 \mathrm{~nm}$, visualizando-se 
uma marcação dourada, enquanto que em meio ácido é excitado em 325nm (luz UV) e emite fluorescência em 410nm, obtendo-se uma marcação azulada. Já o FITC é excitado em 490nm (espectro do azul) e emite fluorescência em 525nm, observando-se uma marcação esverdeada.

A figura 6 demonstra que ocorreu o transporte retrógrado do FluoroGold a partir das projeções dos neurônios dopaminérgicos localizados no $\mathrm{CPu}$ até o corpo celular na SNpc, como pode ser visualizado pela sobreposição da marcação do FluoroGold com o anticorpo para TH na SNpc (painel C da Figura 6). A partir desse resultado, pode-se afirmar que as coordenadas para a indução de DP nos camundongos selvagens e nocautes estão precisas, permitindo assim, a certificação de que a droga está sendo injetada no local correto do CPu.

Figura 6. Verificação do transporte retrógrado do FluoroGold para a SNpc e marcação dos neurônios dopaminérgicos com o anticorpo para TH
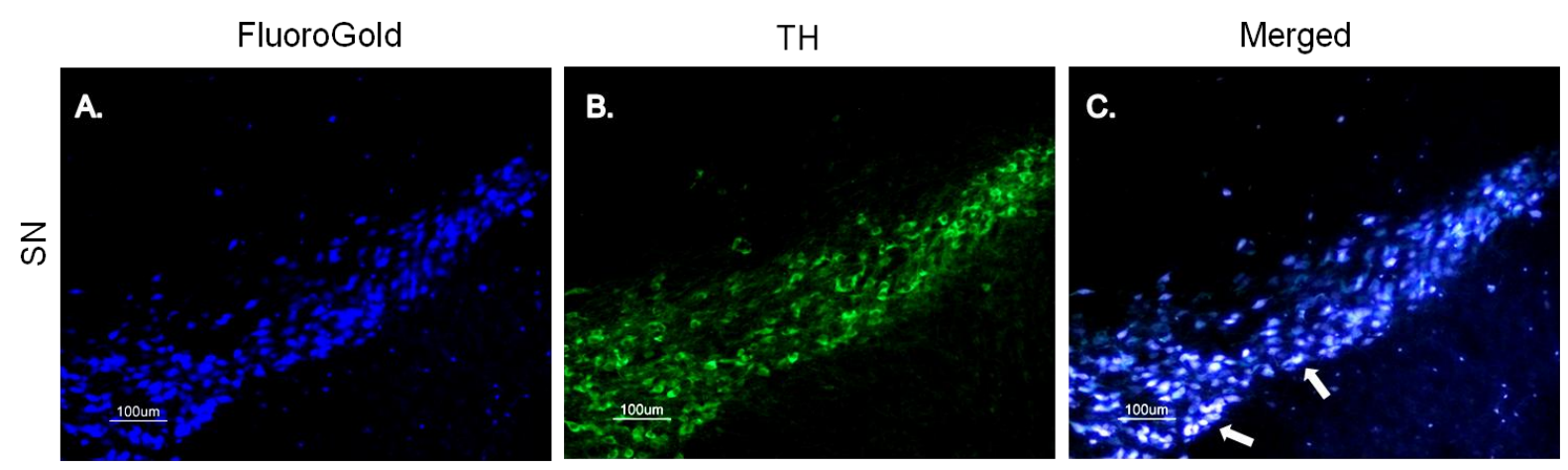

A. Identificação de corpos celulares contendo vesículas com FluoroGold na SNpc, caracterizada pela fluorescência azulada emitida. Esse espectro da fluorescência é decorrente do processamento do tecido em meio ácido. B. Marcação dos neurônios dopaminérgicos com o anticorpo para tirosina hidroxilase (TH) utilizando um anticorpo secundário acoplado a FITC. C. Sobreposição das marcações do FluoroGold com FITC. A partir dessa sobreposição, pode-se observar que os neurônios que captaram o FluoroGold são dopaminérgicos (setas). SN - substância negra pars compacta; TH - tirosina hidroxilase. 


\subsection{Perfomance no teste do cilindro}

O gráfico da figura 7 apresenta os valores referentes às porcentagens do uso do membro anterior esquerdo (contralateral à lesão) em relação ao total (valores do lado esquerdo, direito e ambos) durante a exploração na parede do cilindro, levando em consideração o período de tempo após a cirurgia. De acordo com os resultados obtidos, os camundongos selvagens apresentaram uma redução significativa tanto com 7 dias quanto com 14 dias após a cirurgia em relação aos valores obtidos no período anterior a injeção de 6-OHDA (ANOVA de duas vias; para 7 dias, $p=0,007$ e $F(1,19)=24,48$; ; para 14 dias, $p=3 \times 10^{-6}$ e $\left.F(1,19)=24,48\right)$. Essa redução significativa do uso do membro esquerdo ao longo do tempo pode ser um indicativo dos efeitos do déficit motor causado pela neurodegeneração unilateral iniciada pela 6-OHDA na SNpc.

Além disso, os camundongos nocautes mantiveram a mesma média de porcentagem do uso do membro contralateral nos três períodos de tempo analisados, indicando a ausência de déficit motor causada pela 6-OHDA. A interação entre as duas variáveis analisadas (tempo e genótipo) foi significativa (ANOVA de duas vias; $p=0,002 ; F(1,19)=9,29$ ), evidenciando que a ausência do gene da Nox2 foi determinante para as diferenças observadas no desempenho do teste. No sétimo dia após a cirurgia, a redução observada nos WT foi significativa em relação aos KO com $p=0,041(F(1,19)=4,82)$. O mesmo resultado foi observado com 14 dias após a injeção de 6-OHDA $\left(p=1,8 \times 10^{-4} ; F(1,19)=21,45\right)$. 
Figura 7. Camundongos gp $91^{\text {phox-l }}$ e submetidos à 6-OHDA não apresentaram déficit motor avaliado pelo teste do cilindro.

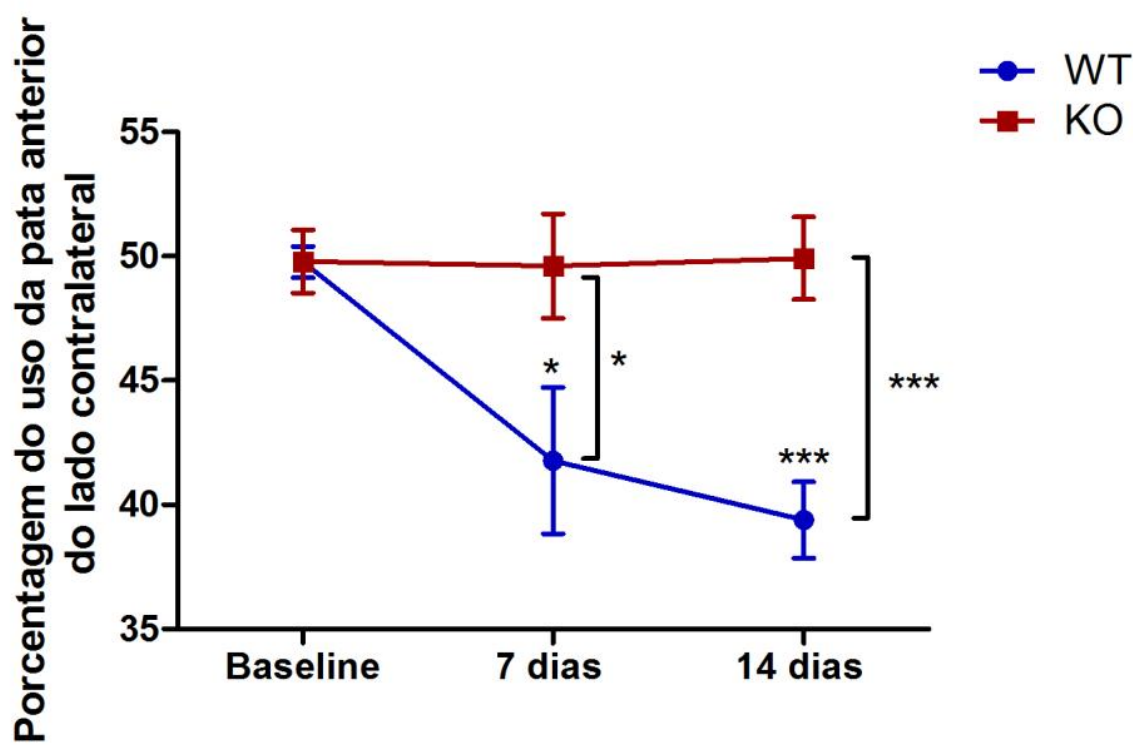

Gráfico representativo da porcentagem de exploração do membro anterior esquerdo (contralateral a lesão) em relação ao total (direito, esquerdo e ambos) realizada por animais selvagens e nocautes. Os animais WT apresentaram redução significativa nos dias 7 e 14 após a cirurgia quando comparado com os valores anteriores à cirurgia (baseline). Além disso, as porcentagens nos dias 7 e 14 também foram significativamente inferiores aos dos nocautes no mesmo período. ${ }^{*} p<0,05 ;{ }^{* *} p<0,01$.

3.5. Curva do perfil microglial versus o tempo após a injeção da droga 6-OHDA

Estudos demonstram que a ativação microglial precede a neurodegeneração dopaminérgica em modelos para DP $(103,104)$. Entretanto, essas curvas de ativação microglial foram realizadas em ratos (103) ou em camundongos fêmeas (104) com doses de 6-OHDA superiores às utilizadas nesse estudo. Com o intuito de identificar o padrão de ativação microglial nos modelos de neurodegeneração (WT) e de neuroproteção $(\mathrm{KO})$, foram realizadas análises do processo neurodegenerativo a partir da marcação de $\mathrm{TH}$, bem como da ativação microglial por meio do anticorpo anti-lba-1 e anti-iNOS após 3 e 15 dias da lesão. 


\subsubsection{Perfil neurodegenerativo e microglial após 3 dias da cirurgia}

A figura 8 apresenta os resultados obtidos a partir da marcação com o anticorpo anti-TH no CPu e na SNpc dos camundongos selvagens e nocautes após 3 dias da indução de DP. Nos camundongos WT, não houve diferença significativa entre as densidades dos terminais dopaminérgicos tanto no lado controle quanto no experimental do $\mathrm{CPu}$, como pode ser visualizado no gráfico $\mathrm{C}$ (Teste-t pareado; $p=0,518 ; t=0,709)$.

Com relação ao número de neurônios dopaminérgicos da SNpc, obtevese uma média de $44,93( \pm 16,26)$ no lado controle e uma média de $35,16( \pm 9,74)$ no lado experimental dos animais WT. Essa diferença entre as médias foi marginalmente significativa, como mostra o gráfico $F$ (Teste-t pareado; $p=0,067 ; t=$ 2,497).

Os mesmos resultados foram verificados nos animais $\mathrm{KO}$, sendo que não houve redução significativa da marcação de TH no lado com 6-OHDA nas duas regiões analisadas. Os painéis $\mathrm{G}-\mathrm{I}$ apresentam as imagens e os resultados referentes ao $\mathrm{CPu}$ (Teste-t pareado; $\mathrm{p}=0,59 ; \mathrm{t}=-0,581$ ). $\mathrm{Na} \mathrm{SNpc}$, as médias dos lados controle e tratado foram $63,36( \pm 5,45)$ e $49,38( \pm 4,19)$, respectivamente, e os resultados estão representados no gráfico $M$ (Teste t pareado; $p=0,051 ; t=-2,56$ ). 
Figura 8. Após 3 dias de indução com 6-OHDA, não foi observada redução significativa da marcação de TH tanto no CPu quanto na SNpc nos animais WT e KO.
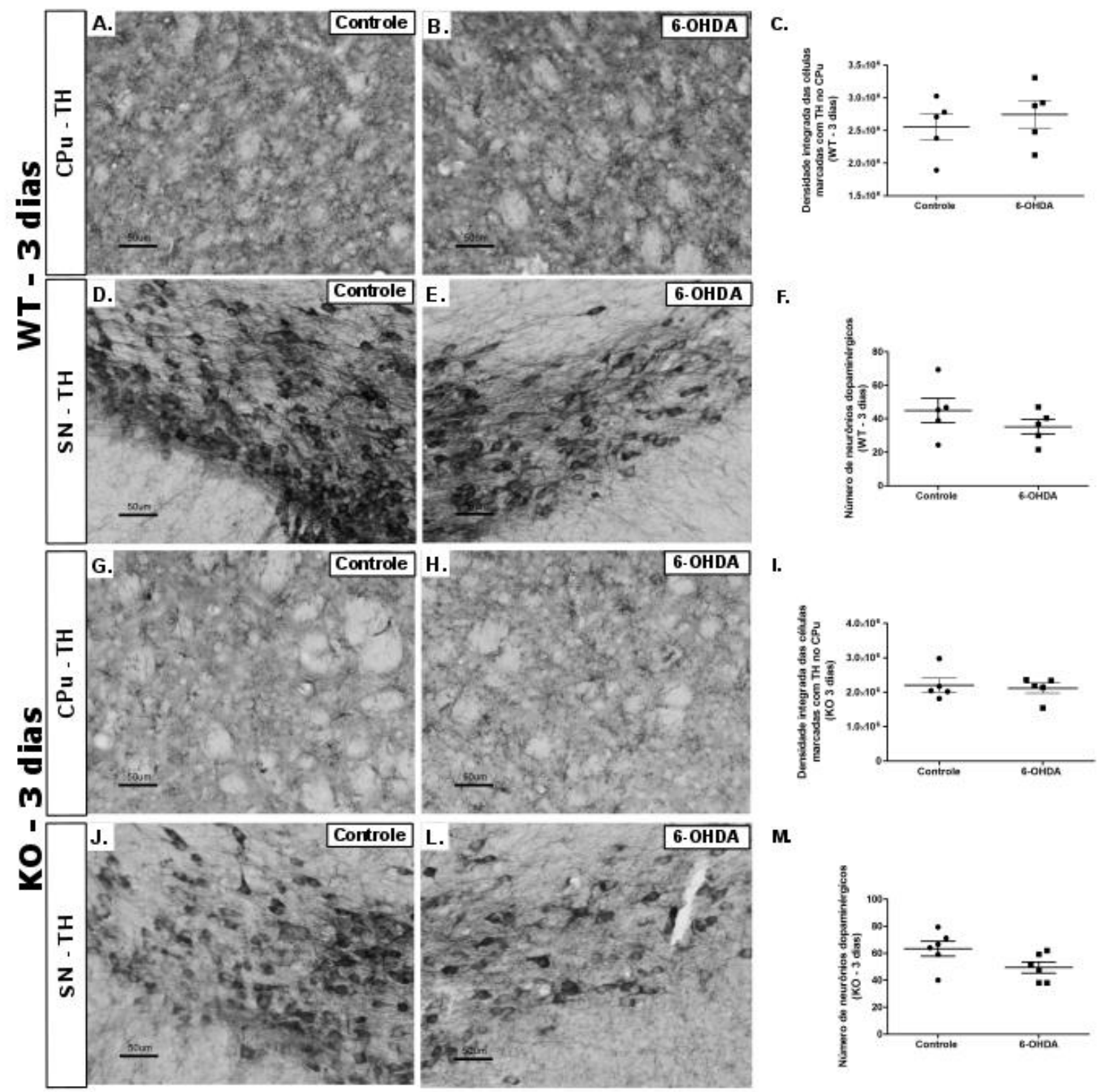

A. Terminais dopaminérgicos marcados com $\mathrm{TH}$ no $\mathrm{CPu}$ do lado controle (injeção de veículo) de um animal selvagem. B. Terminais dopaminérgicos do lado experimental (injeção de 6-OHDA). C. Gráfico mostrando que após 3 dias da injeção da droga não houve diferença significativa entre o lado com 6-OHDA e o controle no CPu. D. Neurônios dopaminérgicos de animais WT no lado controle. E. Neurônios dopaminérgicos no lado com 6-OHDA. F. Gráfico mostrando que não houve diferença no número de neurônios dopaminérgicos entre o lado controle e experimental dos animais WT. G. Terminais 
dopaminérgicos marcados com $\mathrm{TH}$ no $\mathrm{CPu}$ do lado controle de animais nocautes. $\mathbf{H}$. Terminais dopaminérgicos do lado experimental de animais nocautes. I. Gráfico mostrando que não houve diferença significativa entre as densidades da marcação com TH nos lados controle e experimental dos animais nocautes. J. Neurônios dopaminérgicos do lado controle de animais nocautes. L. Neurônios dopaminérgicos do lado com 6-OHDA dos nocautes. M. Gráfico mostrando que não houve diferença significativa no número de neurônios entre os dois lados analisados nos nocautes $(n=6)$. Esses gráficos apresentam a média \pm erro padrão de 5 cortes de tecido de cada animal com $n=5$. WT=selvagem; $\mathrm{KO}=$ nocaute.

Em relação à ativação microglial, observou-se que a densidade de células marcadas com lba-1 foi maior no lado experimental do CPu tanto nos selvagens quanto nos nocautes, enquanto que na SNpc apenas foi identificado aumento significativo nos $\mathrm{KO}$. Como pode ser notado nos painéis $A$ e $B$ da figura 9 , o lado com 6-OHDA dos animais WT apresentou aumento da densidade de células lba-1+ em relação ao lado controle (Teste-t pareado; $p=0,024 ; t=4,25$ ). Já na $S N p c$, não foi observada diferença significativa da marcação entre o lado controle (painel D) e experimental (painel $E$ ), com $p=0,88$ (Teste-t pareado; $t=-0,164$ ). Esses resultados estão representados no gráfico $\mathrm{F}$.

Assim como verificado para os selvagens, os nocautes também apresentaram aumento de células $\mathrm{Iba-1^{+ }}$ no lado com 6-OHDA em relação ao controle no CPu. Esses resultados estão apresentados no gráfico I (Teste-t pareado; $p=0,007 ; t=6,54)$. Diferentemente do observado nos WT, a densidade de células lba-1+ foi maior significativamente no lado com 6-OHDA em relação ao controle na SNpc dos KO (Teste-t pareado; $p=0,025 ; t=4,17$ ), como pode ser visualizado no gráfico $M$. 
Figura 9. Aumento da densidade de microglia ativada no lado com 6-OHDA da SNpc apenas é observado nos KO após 3 dias.
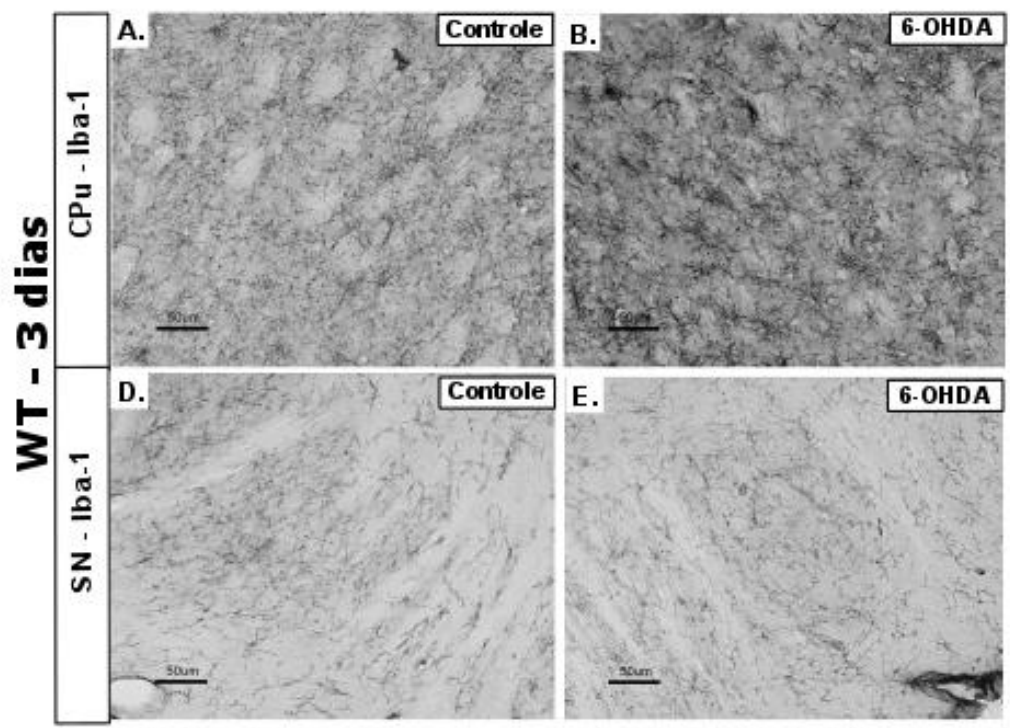

c.

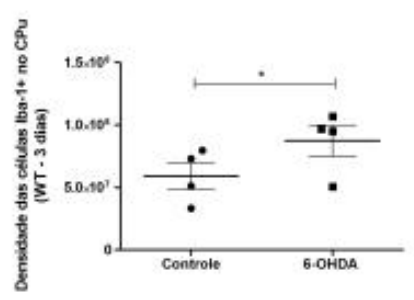

F.
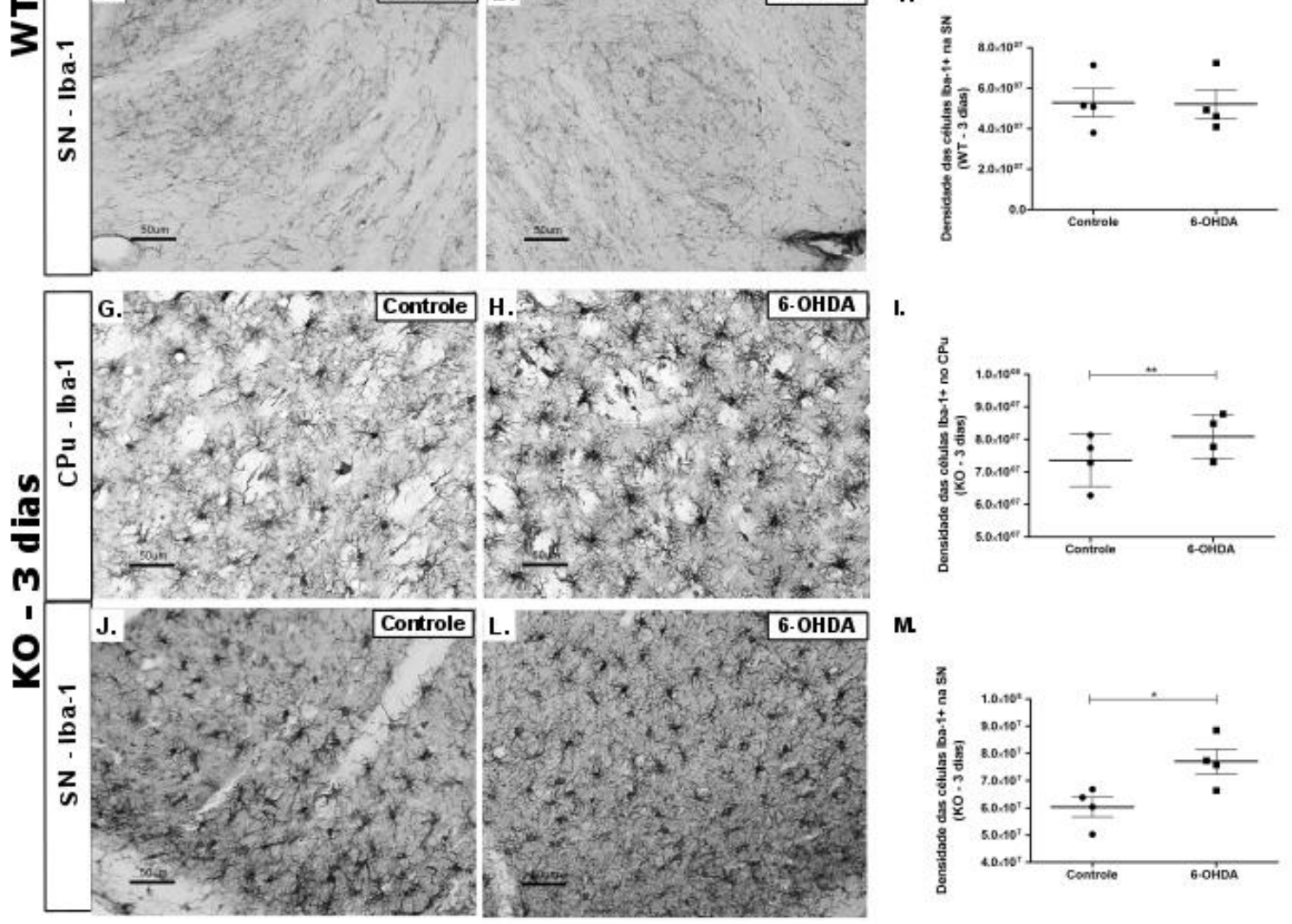

A-F. Resultados da marcação com lba-1 referentes aos animais WT. A. Marcação com o anticorpo anti-lba-1 no lado controle do CPu. B. Aumento da densidade de microglia ativada no CPu do lado com 6-OHDA. C. Gráfico mostrando que após 3 dias da injeção da droga houve um aumento significativo no CPu no lado experimental em relação ao controle. D. Marcação de Iba-1 na SNpc no lado controle. E. Marcação de lba-1 na SNpc no lado experimental. F. Gráfico mostrando que não houve diferença significativa de microglia ativada na SNpc entre o lado experimental e controle. G-M. Resultados da marcação com Iba-1 nos animais nocautes. G. Células Iba-1+ no lado controle do CPu. H. Células Iba-1+ no lado experimental do CPu. I. Gráfico mostrando o aumento de microglia ativada no lado 
com 6-OHDA do CPu dos animais nocautes. J. Células Iba-1+ no lado controle da SNpc. L. Células Iba-1+ no lado com 6-OHDA da SNpc. M. Gráfico mostrando o aumento significativo de células Iba-1+ no lado com 6-OHDA na SNpc dos KO. Os gráficos apresentam a média \pm erro padrão de 5 cortes de tecido de cada animal, $\mathrm{n}=4$. WT=selvagem; $\mathrm{KO}=$ nocaute. * $p<0,05 ;{ }^{* * *} p<0,01$.

Além disso, foi verificada a marcação de iNOS no CPu e na SNpc dos dois grupos de animais. Como pode ser observada na figura 10, houve um aumento significativo desse marcador nas duas regiões analisadas apenas nos camundongos selvagens no período de 3 dias após a cirurgia. $O$ gráfico $C$ apresenta as médias gerais e de cada indíviduo dos dois lados analisados no $\mathrm{CPu}$, mostrando que houve um aumento significativo de iNOS no lado com a neurotoxina em relação ao lado controle nos WT (Teste t pareado; $p=0,005 ; t=5,51$ ). Com relação à marcação na SNpc dos WT, observa-se o mesmo padrão que no $\mathrm{CPu}$, com aumento significativo no lado experimental em relação ao controle (gráfico $\mathrm{F}$ da figura 10; teste t pareado, $\mathrm{p}=0,014 ; \mathrm{t}=5,16)$.

Já nos animais $\mathrm{KO}$, não houve diferença significativa entre os dois lados analisados tanto no $\mathrm{CPu}$ (gráfico I da figura 10; teste t pareado; $\mathrm{p}=0,15 ; \mathrm{t}=2,25$ ) quanto na SNpc (gráfico $\mathrm{M}$; teste $\mathrm{t}$ pareado; $\mathrm{p}=0,10 ; \mathrm{t}=2,87$ ). Apesar de ser observado um aparente aumento no lado com a 6-OHDA, a variação intra-individual impossibilitou que essa diferença fosse significativa. 
Figura 10. Após 3 dias da neurotoxina, a marcação de iNOS está elevada significativamente no CPu e na SNpc dos WT.

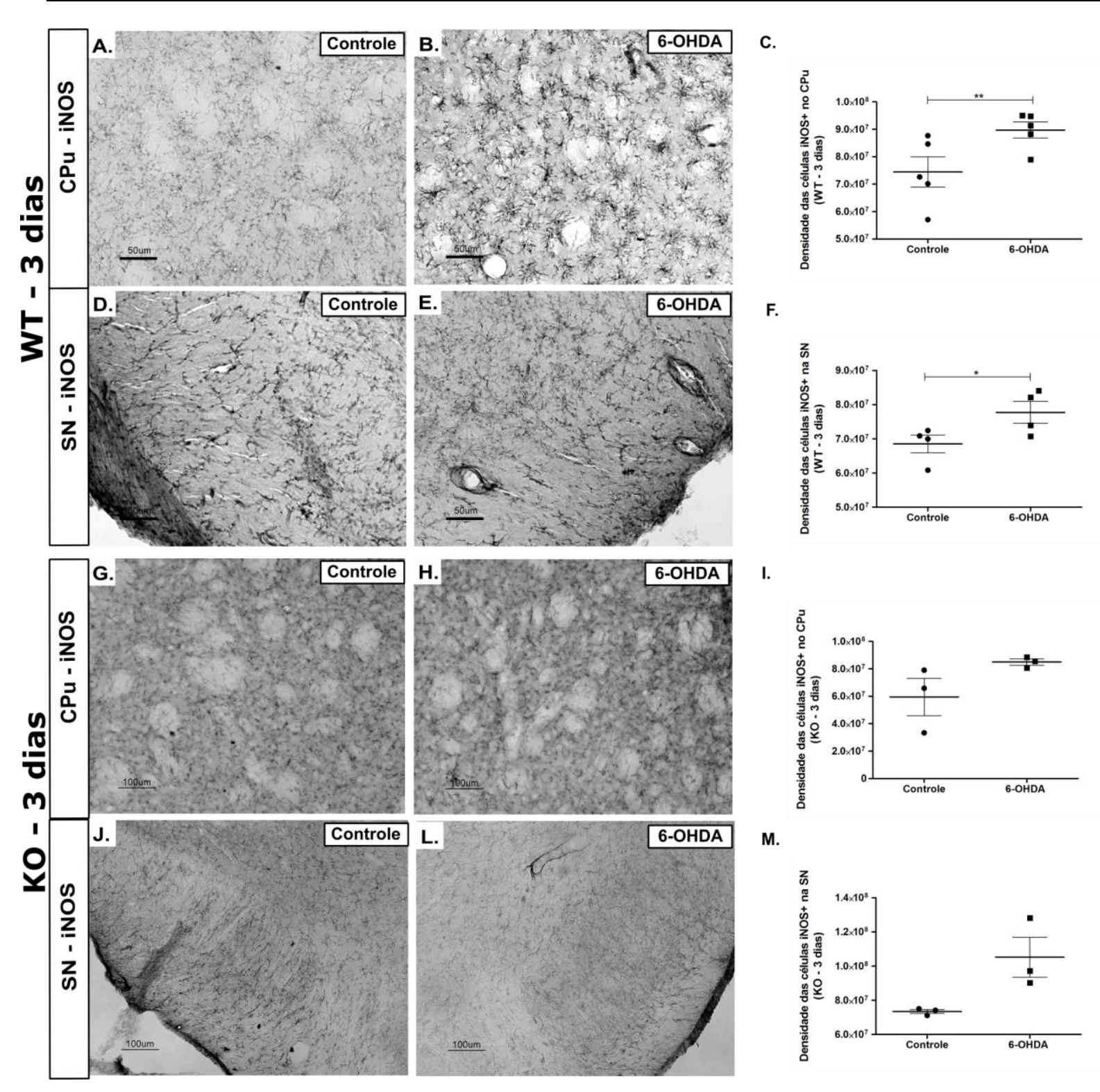

A-F. Resultados da marcação com iNOS nos animais WT. A. Marcação de iNOS no lado controle do CPu. B. Aumento da densidade de células iNOS+ no lado com 6-OHDA do CPu. C. Gráfico mostrando que houve um aumento significativo da marcação de iNOS no lado com a droga no CPu dos WT após 3 dias da injeção de 6-OHDA. D. Marcação de iNOS no lado controle da SNpc. E. Marcação de iNOS no lado experimental da SNpc. F. Gráfico mostrando que foi observado um aumento significativo da marcação de iNOS no lado experimental em relação ao controle na SNpc dos WT após 3 dias da cirurgia. G-M. Resultados da marcação de iNOS nos animais nocautes. G. Células marcadas com iNOS no lado controle do CPu. H. Marcação de iNOS no lado experimental do CPu. I. Gráfico mostrando que apesar do aparente aumento no lado experimental em relação ao controle, 
não houve diferença significativa entre os lados no CPu dos KO após 3 dias. J. Marcação de iNOS no lado controle da SNpc. L. Marcação de iNOS no lado experimental da SNpc. M. Gráfico mostrando que não houve diferença significativa entre os lados com 6-OHDA e controle na SNpc dos KO após 3 dias de cirurgia. Os gráficos apresentam a média \pm erro padrão de 5 cortes de tecido de cada animal, $n=3-5$. WT=selvagem; $K O=$ nocaute. ${ }^{*} p<0,05$; ${ }^{* * *} \mathrm{p}<0,01$.

\subsubsection{Perfil neurodegenerativo e microglial após 15 dias da cirurgia}

Outro período de tempo analisado foi o de 15 dias após a indução de DP e os resultados referentes à marcação com TH nos camundongos WT e KO estão apresentados na figura 11. Nos WT, verificou-se que a presença da neurotoxina reduziu significativamente a marcação de $\mathrm{TH}$, tanto no $\mathrm{CPu}$ quanto na SNpc. O gráfico $\mathrm{C}$ apresenta os resultados referentes aos terminais dopaminérgicos e mostra a sua redução no lado experimental quando comparado ao controle (Teste-t pareado; $\mathrm{p}=0,004 ; \mathrm{t}=-6,16)$. Com relação à $\mathrm{SNpc}$, a média dos neurônios dopaminérgicos no lado controle foi de 104,23 $( \pm 24,29)$ e no lado experimental foi de $45,63( \pm 39,75)$, sendo que essa diferença foi significativa como pode ser visualizado no gráfico $F$ (Teste-t pareado; $p=0,003 ; t=-6,27$ ).

Diferentemente do esperado, os mesmos resultados obtidos nos WT foram verificados para os $\mathrm{KO}$ e estão apresentados nos painéis G-M da figura 11. No gráfico I, a redução dos terminais dopaminérgicos foi significativa em relação ao lado controle (Wilcoxon; $p=0,008 ; z=-2,66$ ) Essa redução pode ser verificada ao comparar a ausência de marcação de TH no painel $\mathrm{H}$ com a presença do mesmo no G. $O$ gráfico $M$ apresenta os resultados referentes à $\mathrm{SNpc}$, sendo que a média de neurônios no lado controle foi de $110,20( \pm 35,73)$ e do lado experimental foi de 68,34 $( \pm 29,09)$. Essa diferença foi significativa com $p=0,034$ (Teste-t pareado; $t=-2,62$ ). 
Figura 11. A marcação de TH nos terminais e nos neurônios dopaminérgicos está reduzida significativamente nos WT e KO após 15 dias de indução de DP.
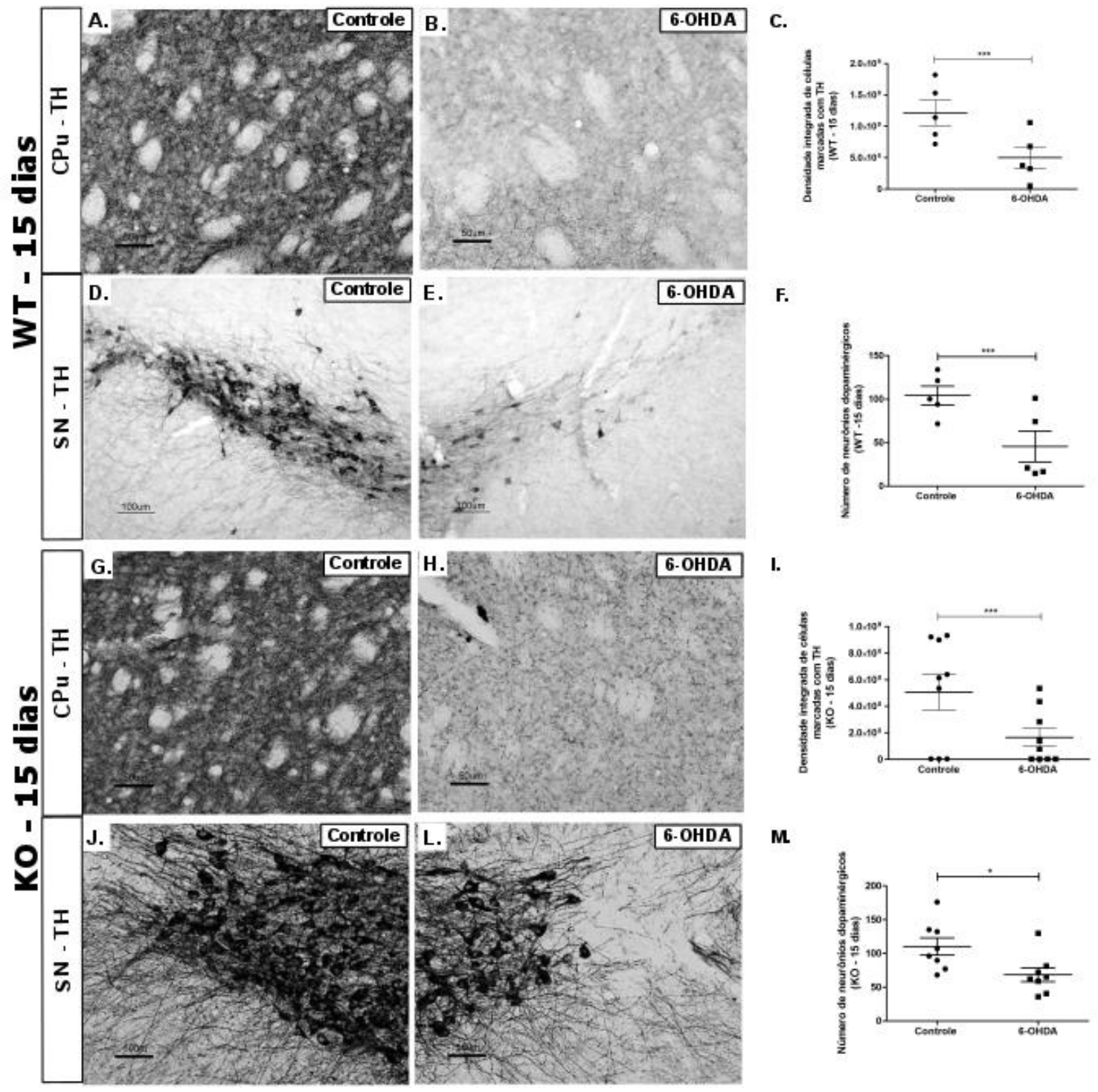

A-F. Resultados referentes à marcação com TH nos camundongos selvagens. A. Terminais dopaminérgicos no lado controle. B. Perda dos terminais dopaminérgicos no lado com 6OHDA. C. Gráfico mostrando que após 15 dias da injeção da droga houve diferença significativa entre o lado com 6-OHDA e o controle no CPu. D. Neurônios dopaminérgicos no lado controle. E. Identificação da redução de neurônios dopaminérgicos no lado experimental quando comparado com o lado controle. F. Gráfico representativo da redução de neurônios dopaminérgicos do lado experimental em relação ao controle, sendo que essa diferença é significativa. G-M. Resultados referentes à marcação com TH nos camundongos nocautes para Nox2. G. Terminais dopaminérgicos no lado controle. H. Perda dos terminais 
dopaminérgicos no lado com 6-OHDA. I. Gráfico mostrando a redução significativa dos terminais dopaminérgicos após 15 dias da indução com 6-OHDA. J. Neurônios dopaminérgicos no lado controle. L. Redução de neurônios dopaminérgicos no lado com 6OHDA. M. Gráfico representativo da redução significativa de neurônios dopaminérgicos após 15 dias da administração da neurotoxina em nocautes para Nox2. Os gráficos apresentam a média \pm erro padrão de 5 cortes de tecido de cada animal, $n=5$ para os WT e $\mathrm{n}=8$ para os $\mathrm{KO}$. WT=selvagem; $\mathrm{KO}=$ nocaute. ${ }^{*} \mathrm{p}<0,05 ;{ }^{* * *} \mathrm{p}<0,01$.

Com relação à ativação microglial, observou-se um aumento de células lba-1+ no lado com a neurotoxina após 15 dias da sua administração, nas duas regiões cerebrais analisadas, bem como nos dois grupos do estudo. O gráfico $\mathrm{C}$ da figura 12 mostra o aumento significativo de células lba-1+ no lado lesionado com relação ao controle no $\mathrm{CPu}$ dos camundongos WT (Teste-t pareado; $\mathrm{p}=3 \times 10^{-5} ; \mathrm{t}=21,14$ ). Da mesma forma, esse aumento significativo foi verificado no lado com a 6-OHDA da SNpc dos WT, como pode ser notado no gráfico $F$ (Teste t pareado; $p=0,038$; $t=3,04)$.

Os nocautes para Nox2 apresentaram o mesmo perfil microglial que os selvagens e os resultados estão apresentados nos painéis G-M da figura 12. A densidade das células lba-1+ no lado direito foi superior ao esquerdo do CPu, como pode ser visualizado no gráfico I (Teste t pareado; $p=0,001 ; t=7,60$ ). Além disso, também foi identificado um aumento significativo no lado experimental da SNpc (gráfico $\mathrm{M}$ ), como pode ser observado ao se comparar as imagens $\mathrm{J}$ e L (Teste-t pareado; $p=0,009 ; t=4,08)$. 
Figura 12. Após 15 dias de cirurgia, houve aumento da densidade de microglia no lado com 6-OHDA do CPu e da SNpc dos WT e KO.

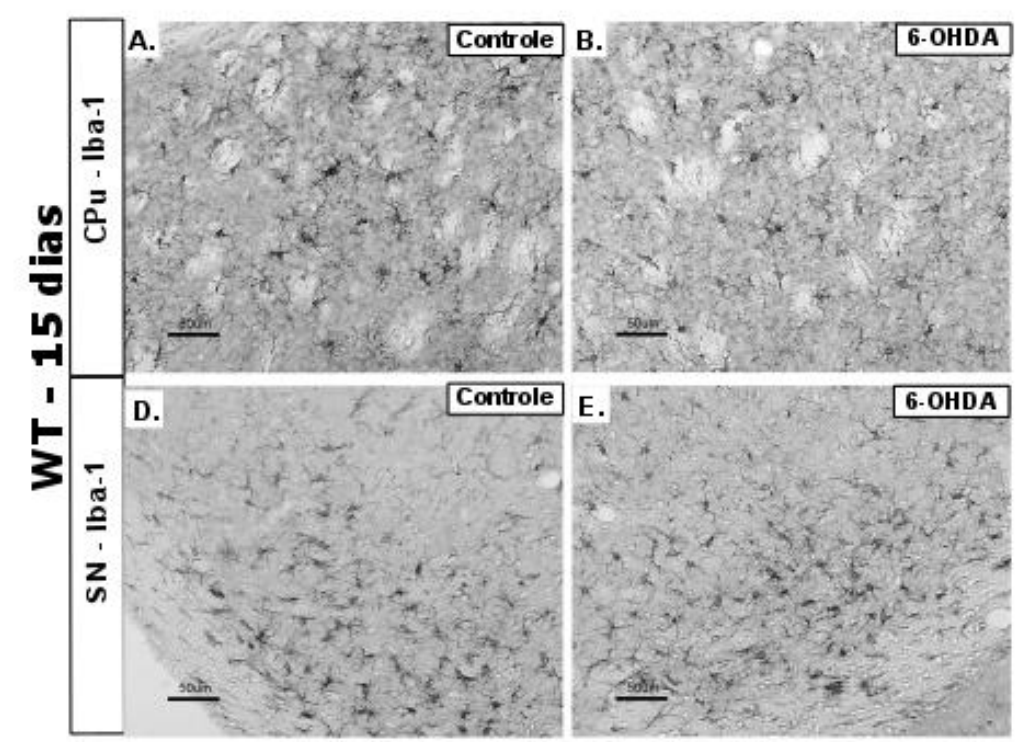

c.

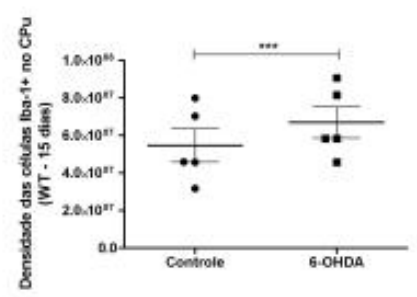

F.
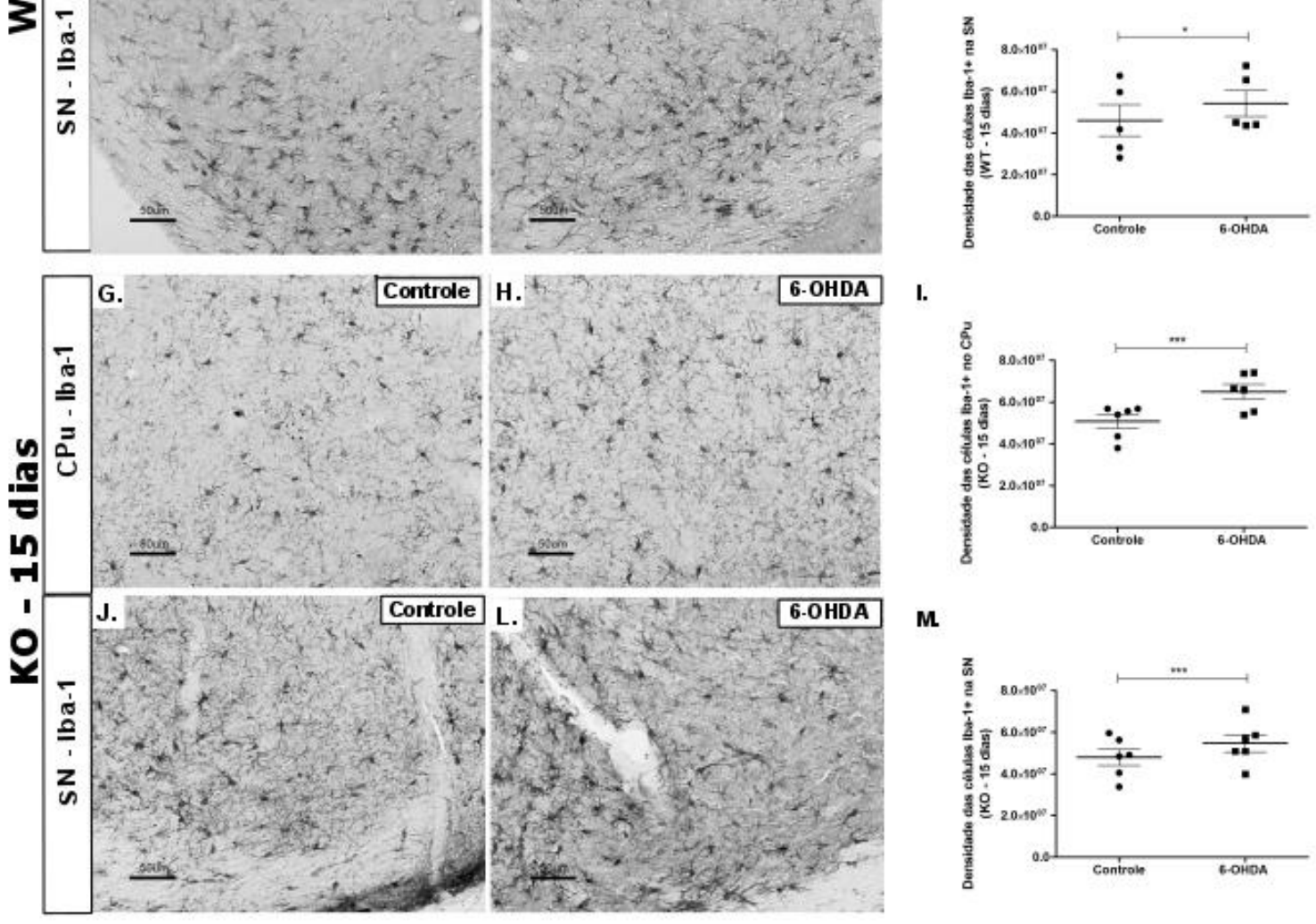

I.

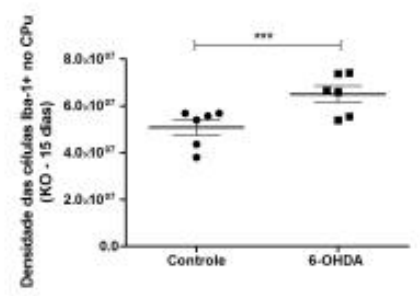

M.

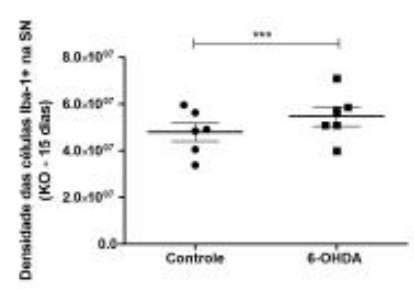

A-F. Resultados referentes à marcação com lba-1 em camundongos selvagens. A. Marcação com o anticorpo anti-lba-1 no lado controle do CPu. B. Aumento da densidade de microglia no CPu do lado com 6-OHDA. C. Gráfico mostrando que após 15 dias da injeção da droga houve um aumento significativo no lado experimental do $\mathrm{CPu}$ em relação ao controle. D. Marcação de Iba-1 na SNpc no lado controle. E. Aumento da marcação de lba-1 na SNpc no lado experimental. F. Gráfico mostrando que houve aumento significativo de microglia no lado com 6-OHDA na SNpc. G-M. Resultados referentes à marcação com Iba-1 em camundongos nocautes. G. Células lba-1+ no lado controle do CPu. H. Células lba-1+ no lado experimental do CPu. I. Gráfico mostrando o aumento significativo das células Iba1+ no lado com 6-OHDA do CPu. J. Células Iba-1+ no lado controle da SNpc. L. Células Iba-1+ no lado experimental da SNpc. M. Gráfico ilustrando o aumento significativo das células Iba-1+ no lado com a neurotoxina da SNpc. Os gráficos apresentam a média \pm erro 
padrão de 5 cortes de tecido de 5 animais. $\mathrm{n}=6$ para os nocautes. WT=selvagem; $\mathrm{KO}=$ nocaute. ${ }^{*} \mathrm{p}<0,05 ;{ }^{* *} \mathrm{p}<0,01$.

A marcação de iNOS apresentou-se elevada no lado com a 6-OHDA na SNpc tanto nos WT quanto nos KO após 15 dias da indução de DP, como pode ser visualizada na figura 13. Nos camundongos WT, não houve diferença significativa entre os lados no CPu no período de tempo analisado, como pode ser visualizado no gráfico $C$ (teste $t$ pareado; $p=0,61 ; t=0,58$ ). Entretanto, houve um aumento significativo no lado experimental da SNpc (gráfico $F ; p=0,003 ; t=19,15$ ).

Com relação aos nocautes para a Nox2, também não foi observada diferença significativa na marcação de iNOS no $\mathrm{CPu}$, apesar da marcação ser bem mais expressiva (gráfico I; Teste t pareado, $p=0,10, t=2,31$ ). Por outro lado, na SNpc houve um aumento significativo no lado experimental em relação ao controle (gráfico $M$; teste t pareado; $p=0,02 ; t=4,39$ ). 
Figura 13. Após 15 dias de cirurgia, houve aumento da marcação de iNOS no lado com 6-OHDA da SNpc dos WT e KO.
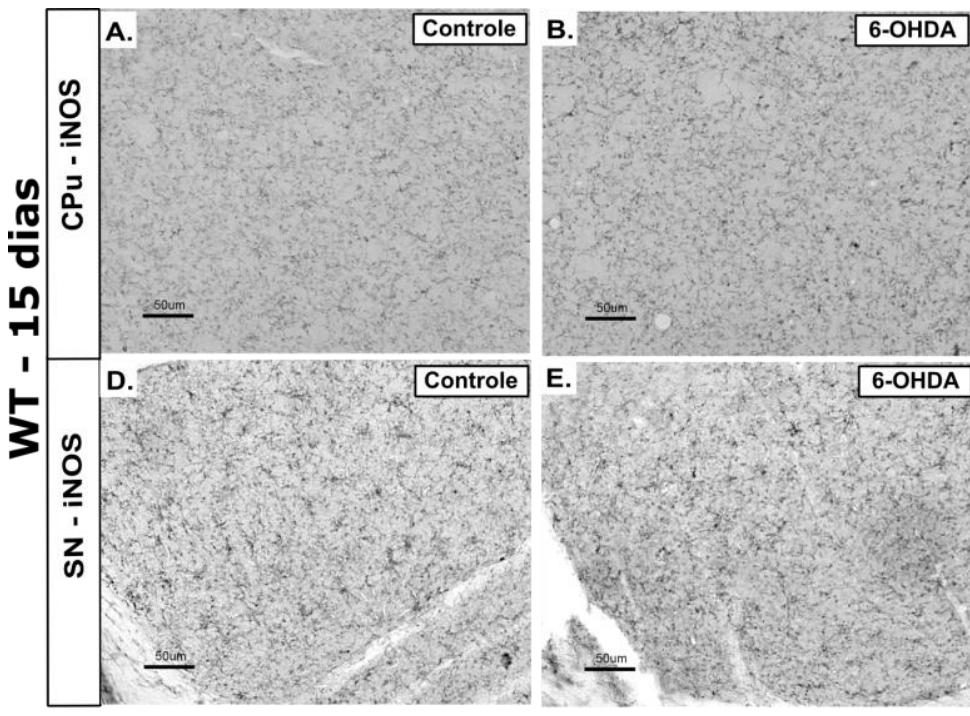

c.
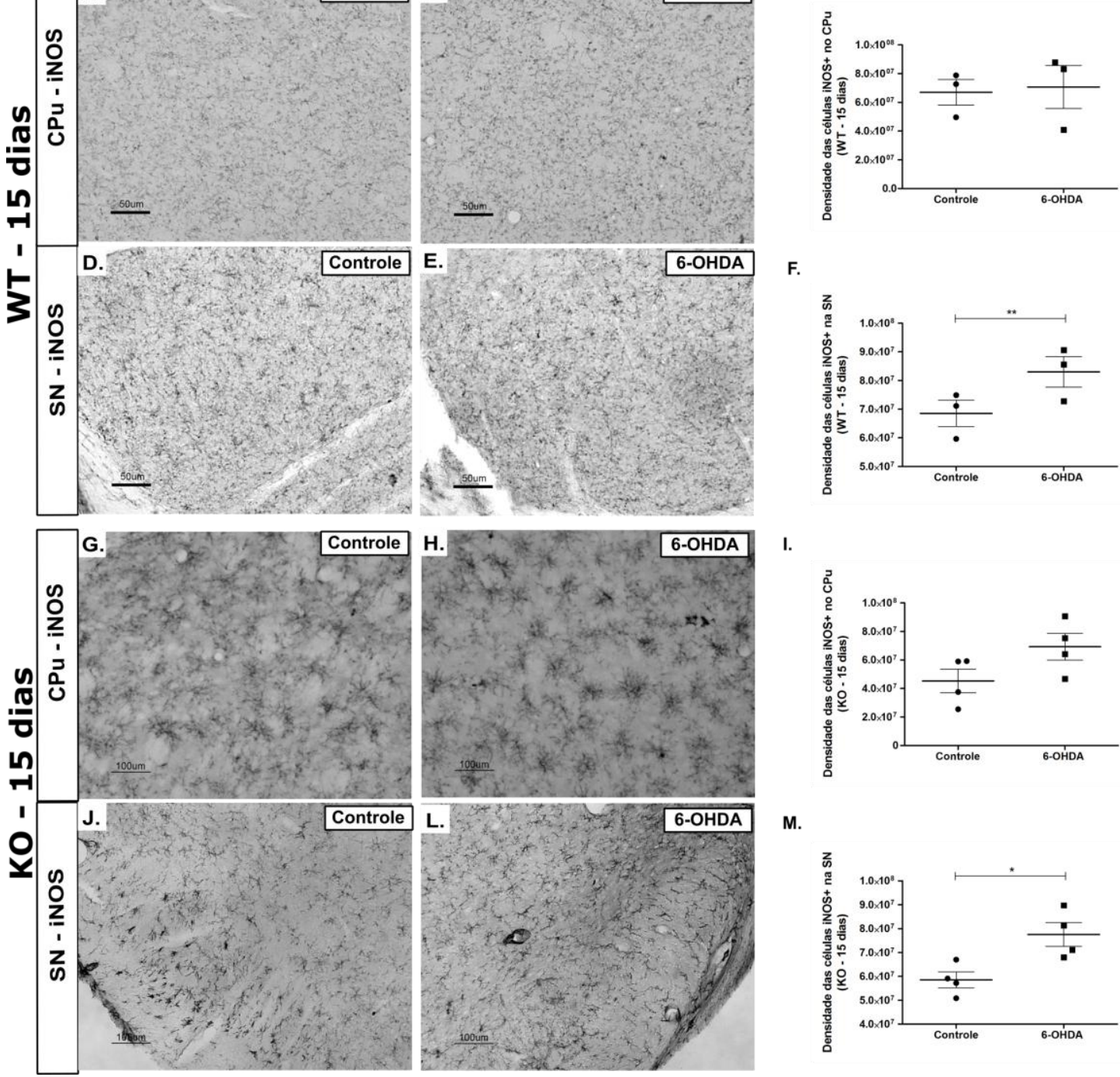

F.

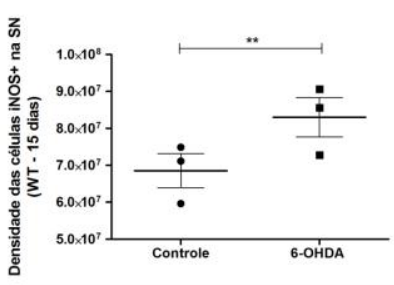

I.

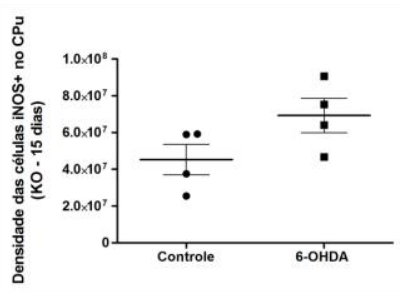

M.

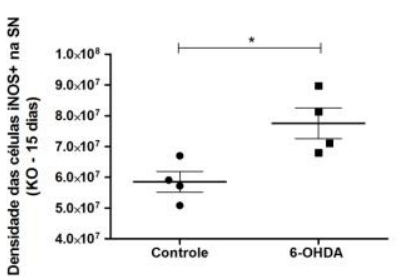

A-F. Resultados referentes à marcação de iNOS nos WT. A. Marcação de iNOS no lado controle do CPu. B. Células marcadas com iNOS no lado experimental do CPu. C. Gráfico mostrando as médias gerais e individuais dos dois lados analisados e indicando que não houve diferença significativa entre os lados no CPu dos WT. D. Marcação de iNOS no lado controle da SNpc. E. Aumento da marcação de iNOS no lado experimental da SNpc. F. Gráfico mostrando o aumento significativo no lado com 6-OHDA em relação ao controle na SNpc dos WT. G-M. Resultados da marcação de iNOS nos animais nocautes para Nox2. G. Células marcadas com iNOS no lado controle do CPu. H. Marcação de iNOS no lado experimental do $\mathrm{CPu}$. I. Gráfico mostrando que não houve diferença significativa entre os lados do CPu na marcação de iNOS. J. Marcação de iNOS no lado controle da SNpc. L. Marcação de iNOS no lado experimental da SNpc. M. Gráfico mostrando que houve um aumento significativo no lado com 6-OHDA em relação ao controle na SNpc dos KO após 15 
dias da cirurgia. Os gráficos apresentam a média \pm erro padrão de 5 cortes de tecido de cada animal, $\mathrm{n}=3-4$. WT=selvagem; $\mathrm{KO}=$ nocaute. ${ }^{*} \mathrm{p}<0,05 ;{ }^{* *} \mathrm{p}<0,01$.

3.5.3. Relação entre o lado experimental e controle dos marcadores analisados após 3 e 15 dias de cirurgia

A partir dos resultados obtidos com as marcações de TH, lba-1 e iNOS no CPu e na SNpc tanto nos camundongos selvagens quanto nos nocautes nos dois períodos (3 e 15 dias), foi realizada a relação entre os lados experimental e controle e os resultados foram comparados entre si. O gráfico A da figura 14 apresenta os valores da marcação de TH no CPu, mostrando que a média da porcentagem do lado lesionado em relação ao controle foi de 109,19\% $( \pm 26,97)$ nos WT com 3 dias e de $97,11 \%( \pm 13,61)$ nos KO correspondentes ao mesmo período. No período de 15 dias, houve uma redução nos valores das médias, sendo que os WT apresentaram $37,03 \%( \pm 21,86)$ e os $K O, 54,86 \%( \pm 38,24)$. A redução observada foi significativa nos dois grupos de animais quando comparado os períodos de 3 e 15 dias (ANOVA de duas vias; Para o WT, $p=3,3 \times 10^{-4} ; \mathrm{F}(3,20)=18,98$; Para KO, $p=0,032$; $F(3,20)=5,33)$, não havendo diferença entre os genótipos nos tempos analisados.

Com relação aos resultados na SNpc, a média da relação após 3 dias nos WT foi de $79,98 \%( \pm 12,99)$ e nos KO foi de $86,25 \%( \pm 16,25)$, enquanto que após 15 dias as médias foram de $38,96 \%( \pm 24,21)$ para o WT e de $66,18 \%( \pm 29,38)$ para os KO (gráfico B da figura 14). A redução do número de neurônios dopaminérgicos ao longo do tempo foi significativa apenas nos WT (ANOVA de duas vias; $p=0,010$; $F(3,20)=8,10)$, não havendo diferença entre os valores de 3 e 15 dias nos $K O$ (ANOVA de duas vias; $p=0,119 ; F(3,20)=2,66$ ). Além disso, ao se comparar os valores dos WT e KO no período de 15 dias, verificou-se que houve diferença estatística entre ambos, indicando que apesar da redução das porcentagens entre os lados analisados, os animais gp91 ${ }^{\text {phox-/- }}$ apresentaram um mecanismo de neuroproteção em relação à toxina, visto que o número de neurônios dopaminérgicos no lado com a 6-OHDA foi superior ao dos selvagens.

Quanto à ativação microglial, a interação entre os dois fatores analisados (genótipo e dias) no CPu por meio da ANOVA de duas vias foi significativo com $p=0,006(F(3,15)=9,98)$. De acordo com o gráfico $C$, observa-se que houve uma redução significativa na porcentagem de células lba-1+ no lado tratado dos KO no período de 3 dias (média de 110,23\% $\pm 4,28$ ) quando comparado com os selvagens 
$(151,50 \% \pm 26,53)$, indicando que a resposta microglial ao dano causado no CPu foi mais intenso nos selvagens $(p=0,001 ; F(3,15)=15,02)$. Contudo, não houve diferença entre os genótipos no período de 15 dias, mostrando que ambos responderam da mesma forma nesse período de tempo $(p=0,744 ; F(3,15)=0,11)$. Além disso, identificou-se uma redução significativa da porcentagem de células nos WT quando comparados os valores de 3 e 15 dias, sendo que as médias foram de 151,50\% $( \pm 26,53)$ para 3 dias e $125,64 \%( \pm 12,18)$ para 15 dias $(p=0,02 ; F(3,15)=6,55)$.

A análise da ANOVA de duas vias das relações das células lba-1+ na SNpc evidenciou interação significativa entre o genótipo e o tempo pós-cirúrgico $(p=0,031$; $F(3,15)=5,62)$, indicando que houve influência do tipo de genótipo nos dias analisados. De acordo com o gráfico $D$, verificou-se que apenas no período de 3 dias os animais WT e KO apresentaram diferença significativa, sendo que a porcentagem de células Iba-1+ no lado com 6-OHDA foi superior no KO quando comparado com os WT ( $p=0,029 ; F(3,15)=5,79)$. Contudo, no período de 15 dias não houve diferença significativa entre os genótipos $(p=0,41 ; F(3,15)=0,69)$. Além disso, observou-se um aumento marginalmente significativo do número de células lba-1+ no dia 15 nos WT quando comparado com o dia 3 ( $p=0,057 ; F(3,15)=4,26)$.

Com relação à marcação de iNOS, no CPu não houve diferença temporal nos grupos WT e KO, bem como, não houve diferença entre os dois genótipos nos dois dias analisados, como pode ser observado no gráfico $E$ (ANOVA de duas vias; Para 3 dias, $p=0,25, F(3,11)=1,44$; Para 15 dias, $p=0,09, F(3,11)=3,34$; Para WT, $p=0,56$, $F(3,11)=0,34 ;$ Para $K O, p=0,90, F(3,11)=0,014)$. Já $S N p c$, observou-se que houve diferença significativa entre os dois genótipos apenas no período de 3 dias, sendo que a média dos WT foi de $113,51 \% \pm 5,2$ e a do $\mathrm{KO}$ foi de 143,05\% $\pm 25,13$, como pode ser visualizado no gráfico $F$ (ANOVA de duas vias; Para 3 dias $p=0,02$, $F(3,10)=7,19$; Para 15 dias, $p=0,30, F(3,10)=1,15)$. Tanto nos WT quanto nos $K O$, não houve diferença significativa em relação ao tempo pós-cirurgico (ANOVA de duas vias; Para WT, $p=0,54, F(3,10)=0,48$; Para $K O, p=0,38, F(3,10)=0,83)$. 
Figura 14. Comparações entre os camundongos WT e KO das relações obtidas entre os lados controle e experimental após 3 e 15 dias da injeção com 6-OHDA.

A.

\section{CPu- TH}

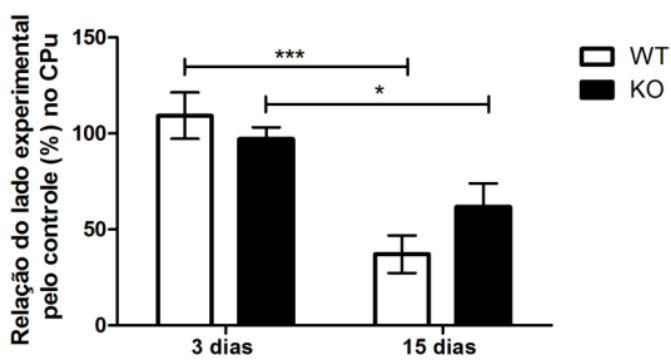

C.

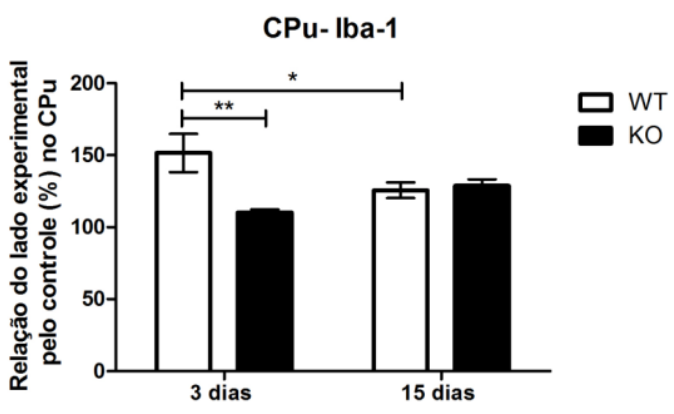

E.

CPu - iNOS

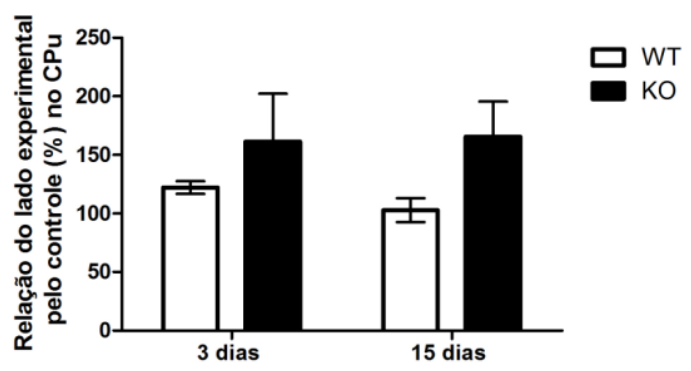

B.

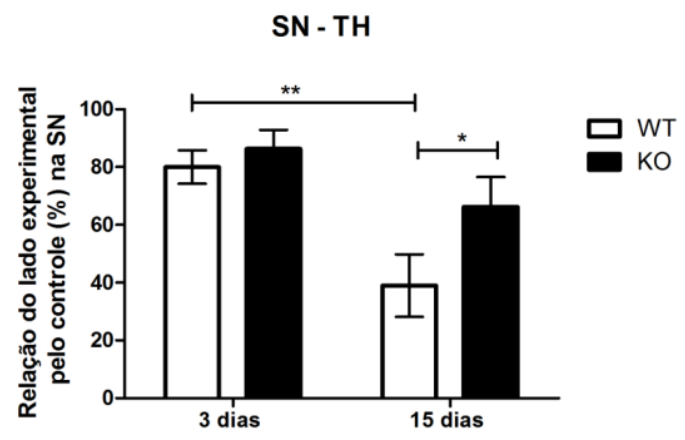

D.

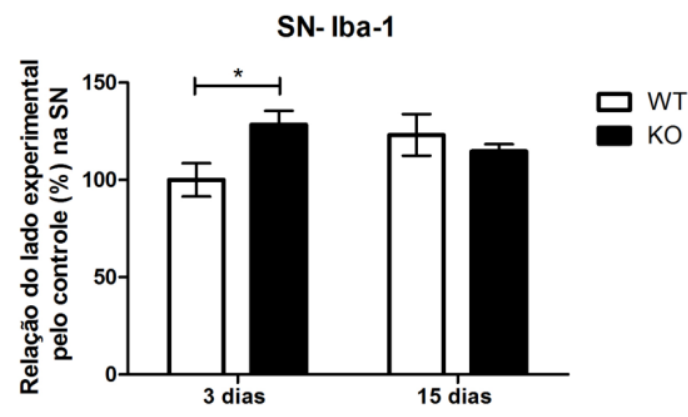

F.

SN-iNOS

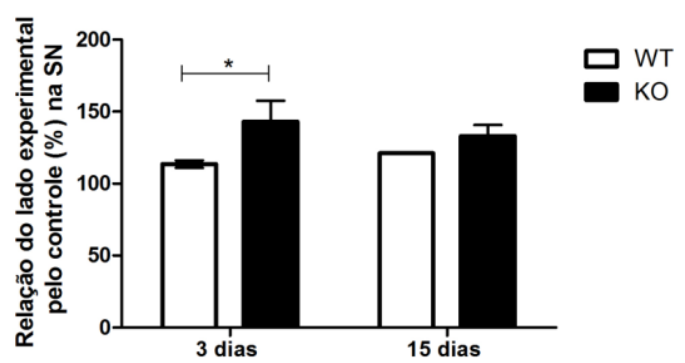

A. Resultado das relações entre lado experimental e controle da marcação de $\mathrm{TH}$ no $\mathrm{CPu}$, mostrando que houve uma redução significativa na relação dos selvagens de 15 dias quando comparado com o de 3 dias, ocorrendo o mesmo nos nocautes. B. Resultado das relações entre os lados experimental e controle da marcação de TH na SNpc, mostrando que a média dos camundongos selvagens reduziu significativamente ao longo do tempo, bem como aponta a diferença significativa entre os KO e WT com 15 dias, evidenciando que os KO não tiveram o mesmo grau de neurodegeneração que os WT. C. Relações entre os lados da marcação de lba-1 no $\mathrm{CPu}$, sendo que a diferença entre os valores foram significativos entre WT e $\mathrm{KO}$ com 3 dias. Além disso, evidencia-se a redução da porcentagem de células nos WT quando comparados os dias 3 e 15 . D. Relações da marcação com Iba-1 na SNpc, evidenciando o aumento significativo no dia 3 da quantidade de células Iba-1+ no lado com 6-OHDA dos KO em relação aos WT. E. Relações da 
marcação de iNOS no $\mathrm{CPu}$, indicando que não houve diferença temporal e entre os genótipos. F. Relações da marcação com iNOS na SNpc, mostrando que o aumento nos KO é significativo em comparação com os WT no período de 3 dias, não havendo diferença significativa no período de 15 dias. WT=wild type; $\mathbf{K O}=$ knockout. ${ }^{*} \mathrm{p}<0,05 ;{ }^{* \star *} \mathrm{p}<0,01$.

3.5. Expressão gênica de Arginase-1, CD86 e Tirosina hidroxilase por meio do PCR em tempo real

\subsubsection{Padronização da extração de RNA}

Inicialmente, o protocolo da extração de RNA foi realizado utilizando o Pellet Pestle Cordless Motor (Thermo Fisher) para homogeneizar o tecido, e não apresentava os seguintes passos: a adição do glicogênio juntamente com 0 isopropanol, precipitação com isopropanol por 12 a 16 horas e a lavagem do pellet com etanol $100 \%$ após a centrifugação do tecido com isopropanol. O RNA extraído das amostras testes de SN está apresentado na Tabela 5.

Tabela 5. Concentrações e dados da pureza das amostras de RNA testes da SN

\begin{tabular}{llllll}
\hline AMOSTRA & {[] $\mathrm{ng} / \mu \mathrm{l}$} & $260 / 280$ & $260 / 230$ & Total em $\mathrm{ng}$ & Total em $\mu \mathrm{g}$ \\
\hline SNE1 & 11,40 & 2,00 & 1,55 & 228,00 & 0,23 \\
SNE2 & 97,50 & 2,05 & 1,88 & 1950,00 & 1,95 \\
SND3 & 188,40 & 1,94 & 0,46 & 3768,00 & 3,77 \\
SNE3 & 175,80 & 2,00 & 0,60 & 3516,00 & 3,52 \\
SND4 & 212,40 & 2,07 & 0,83 & 4248,00 & 4,25 \\
SNE4 & 188,20 & 1,98 & 0,35 & 3764,00 & 3,76 \\
SND5 & 71,00 & 2,04 & 0,24 & 1420,00 & 1,42 \\
SNE5 & 173,20 & 2,09 & 1,28 & 3464,00 & 3,46 \\
SND6 & 268,90 & 2,08 & 1,68 & 5378,00 & 5,38 \\
SNE6 & 182,40 & 2,07 & 0,97 & 3648,00 & 3,65 \\
Média & 156,92 & & & &
\end{tabular}

Como pode ser observado na tabela acima, a concentração média foi de $156,92 \mathrm{ng} / \mu \mathrm{L}$ de RNA, o que significa uma concentração baixa para realizar os posteriores ensaios com os primers escolhidos. A relação 260/280 foi em torno de 2,0 , indicando que o RNA isolado das amostras não apresenta contaminação por 
proteínas, enquanto que a relação $260 / 230$ foi inferior à variação de 1,8-2,2, o que significa a ocorrência de contaminação por fenóis.

Além disso, foi verificada a integridade do RNA em gel de $1 \%$ de agarose, como mostra a figura 15. Segundo os resultados obtidos, todas as amostras apresentaram as bandas $28 \mathrm{~S}$ e $18 \mathrm{~S}$, sem a presença de degradação. Com isso, pode-se afirmar que a metodologia utilizada não prejudicou a integridade do RNA, sendo, portanto, possível utilizá-las para a síntese de cDNA.

Figura 15. Representação de um gel de agarose $1 \%$ para a verificação da integridade do RNA de amostras testes de CPu e SN.

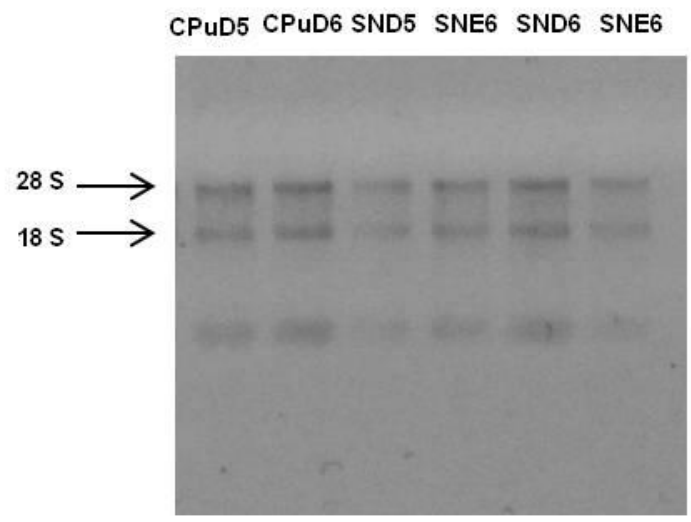

Verificação das bandas 28S e 18S em todas as amostras aplicadas no gel, indicando que 0 RNA está íntegro e pode ser utilizado nas posteriores etapas do PCR em tempo real. CPu caudado-putâmen; SN - substância negra; D - lado direito (lesado) ; E - lado esquerdo (controle); números - identificação das amostras.

Como citado anteriormente, a baixa concentração de RNA isolado para a realização dos ensaios do PCR em tempo real (RT-PCR) resultou na alteração de algumas etapas do processo de extração com o objetivo de aumentar a concentração. As etapas modificadas foram: 1) Alteração do homogeneizador Pellet Pestle Cordless Motor para o sonicador, visando uma homogeneização mais eficaz das amostras; 2) a adição de glicogênio juntamente com o isopropanol, uma vez que o glicogênio é um carreador de RNA, auxiliando na sua precipitação; 3) Incubação da amostra com o isopropanol overnight com a finalidade de aumentar a precipitação do RNA. Além disso, como a relação 260/230 estava inferior a 1,8-2,2, indicando contaminação por fenol, foi adicionada uma etapa de lavagem com etanol 
$100 \%$ após a precipitação com isopropanol, visando retirar o excesso de fenol presente na amostra.

A Tabela 6 mostra algumas das amostras utilizadas no estudo com as alterações descritas acima. Como pode ser observado, a média das concentrações foi de 625,83 ng/ $\mu \mathrm{L}$, indicando um aumento na eficiência da extração de RNA, viabilizando, dessa forma, a realização dos ensaios com uma margem de segurança. Também pode ser notado, que a maioria das amostras apresentou uma relação 260/230 maior do que 1, o que ainda não é indicativo de RNA livre de fenol, mas já é um indício de melhoria na qualidade do material.

Tabela 6. Concentrações e dados da pureza de amostras de RNA da SN

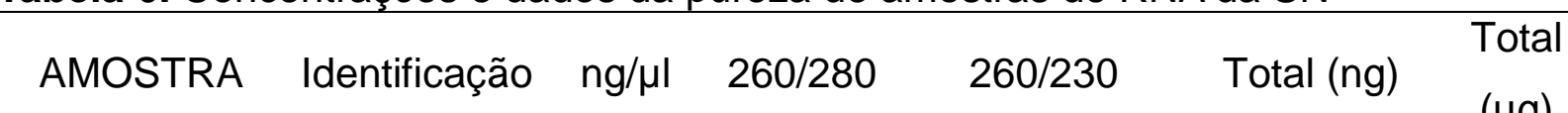

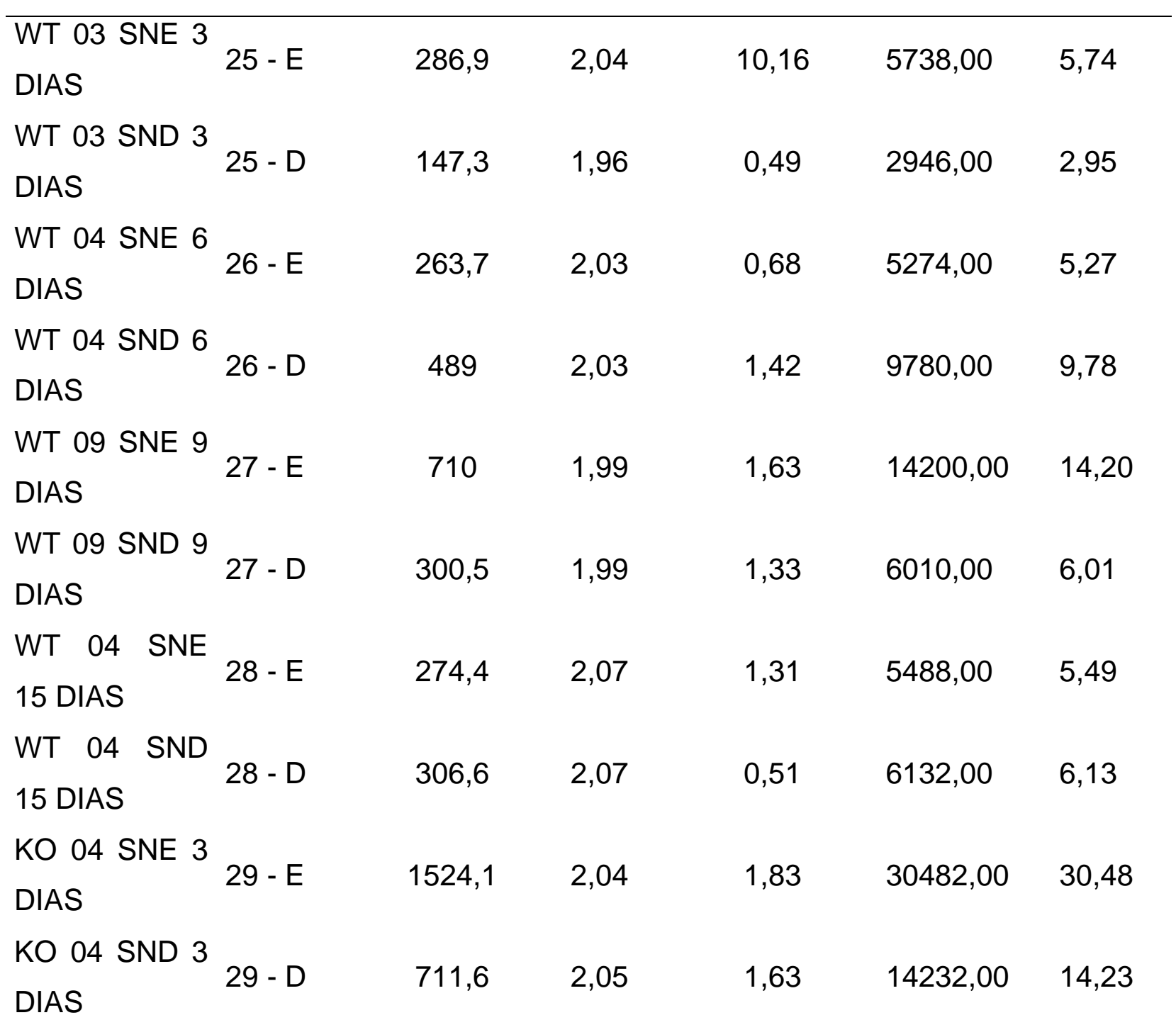


KO 04 SNE 6

DIAS

$30-E$

$1701,4 \quad 2,07$

KO 04 SND 6

DIAS

$30-D$

296,2

2,06

0,5

5924,00

5,92

KO 04 SNE 9

DIAS

$31-E$

$1205,4 \quad 2,08$

1,49

24108,00

24,11

KO 04 SND 9

DIAS

$31-D$

557,2

2,07

1,16

11144,00

11,14

KO 05 SNE 15

DIAS

$32-E$

893,1

2,06

1,21

17862,00

17,86

KO 05 SND

15 DIAS

$32-D$

345,9

2,04

1,14

6918,00

6,92

\section{Média}

625,83

Assim como visualizado no gel das amostras testes (Figura 15), as amostras de SN utilizadas nesse estudo apresentaram as bandas $18 \mathrm{~S}$ e $28 \mathrm{~S}$ indicadas pelas setas (Figura 16). Dessa forma, pode-se afirmar que as moléculas de RNA extraídas estão íntegras e podem ser submetidas à síntese de cDNA.

Figura 16. Representação de um gel de agarose de $1 \%$ para a verificação da integridade do RNA das amostras de SN.

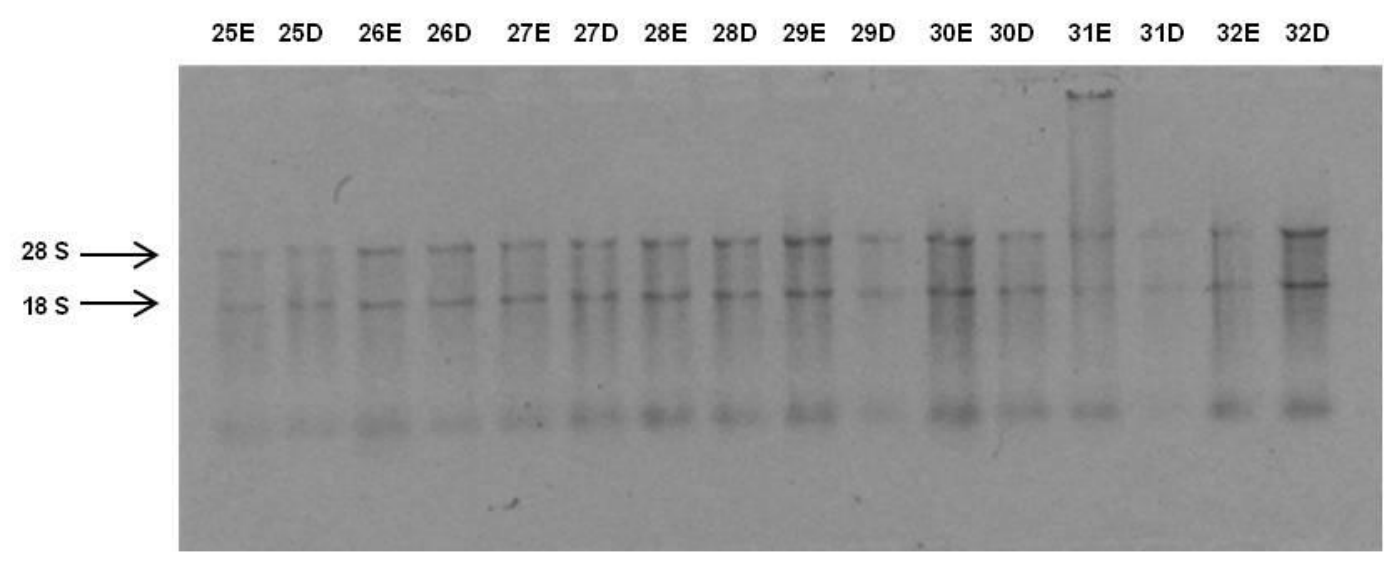

Verificação das bandas 28S e 18S em todas as amostras aplicadas no gel, indicando que o RNA está íntegro. D - lado direito (lesado); E - lado esquerdo (controle); números identificação das amostras mostradas na Tabela 2. 


\subsubsection{Padronização da quantidade de $c D N A$ utilizada para cada primer}

A quantidade ideal de cDNA para ser utilizada na reação de RT-PCR foi padronizada para cada um dos 8 primers descritos na Tabela 3 da seção de materiais e métodos e as curvas padrões estão exibidas na Figura 17. Além disso, os valores da reta como o coeficiente de correlação $\left(r^{2}\right)$ e o slope estão presentes na Tabela 7. O coeficiente de correlação foi utilizado para verificar a linearidade da reta da curva padrão de cada primer, sendo considerados ideais os valores próximos a 0,99 , já o slope foi utilizado para calcular a eficiência dos primers a partir da seguinte equação:

$$
\text { Eficiência }=10^{(-1 / \text { slope })}-1
$$

Para os normalizadores B2M e GAPDH, foram utilizados 10ng, 25ng e 50ng de cDNA de uma amostra teste de SN diluída seriadamente e os dados obtidos estão representados no gráfico do painel A da Figura 15. Como pode ser observado na Tabela 7, o valor de $r^{2}$ da curva de B2M em função dos valores logarítmicos de cDNA foi de 0,99 . O valor de $1 /$ slope foi de $-0,312$, obtendo-se a partir desse número uma eficiência de 1,05 ou $105 \%$, sendo, portanto, considerado um bom primer para ser utilizado no RT-PCR. Quanto ao GAPDH, na primeira tentativa o valor de $r^{2}$ foi inferior a 0,99, levando a uma segunda repetição da reação com a finalidade de se obter uma curva mais linear. O gráfico B representa a segunda tentativa de padronização desse primer e nesse caso foi obtido um valor de eficiência igual a 1,07 ou $107 \%$, sendo assim, considerado ideal para ser utilizado nos ensaios com as amostras.

Os primers CD86, TH1 e TH2 foram padronizados com 25ng, 50ng e $75 \mathrm{ng}$ de cDNA e as curvas estão representadas no painel $\mathrm{C}$ da Figura 17. De acordo com o cálculo de eficiência, todos apresentaram valores próximos ou iguais a 110\%, o que os viabilizam para os posteriores testes. Para a padronização de Arg-1, iNOS e CD206, também foram utilizados $25 \mathrm{ng}$, 50ng e 75ng de cDNA. Como pode ser visualizado no gráfico $D$, somente a curva de Arg-1 ficou linear, com valor de $r^{2}$ de 0,978 , enquanto que as curvas de iNOS e CD206 não ficaram regulares e apresentaram valores de $r^{2}$ inferiores a 0,90 . O cálculo de eficiência de Arg-1 foi de 1,24 ou $124 \%$, esse valor acima de $100 \%$ não significa que esse primer seja o mais eficiente e sim que pode ser decorrente de algum erro na linearidade da reta. 
Como os primers iNOS e CD206 não mostraram valores considerados aceitáveis para serem utilizados, foi realizado um segundo teste com 100ng, 125ng, 150 ng e $175 \mathrm{ng}$ de cDNA. O gráfico E mostra que nessas quantidades de cDNA também não foi obtido uma curva com coeficiente de correlação aceitável, permanecendo com valores de $r^{2}$ inferiores a 0,9. A ausência de uma curva padrão linear de iNOS pode ser devido ao fato de não ter sido utilizado amostras de SN submetidas a 6-OHDA e sim amostras de camundongos naïves. Como iNOS é uma enzima induzível, a ausência de algum fator que induza uma resposta inflamatória pode ter sido determinante para não conseguir padronizar o primer.

Figura 17. Gráficos das curvas padrões dos oito primers utilizados nesse estudo.

A.

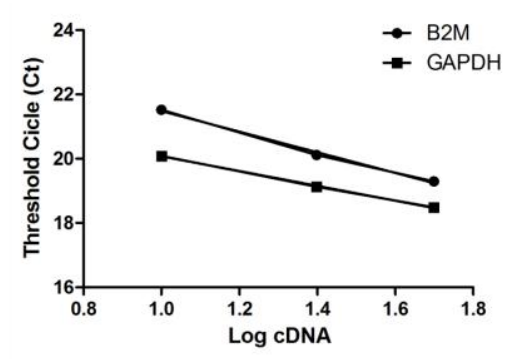

D.

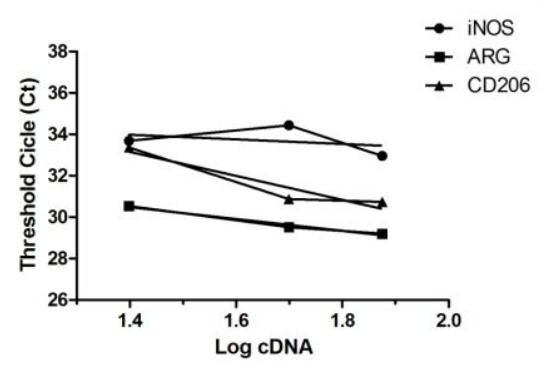

B.

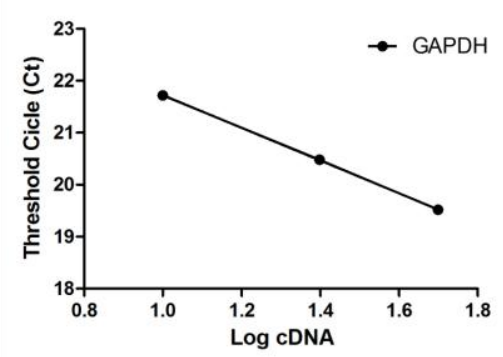

E.

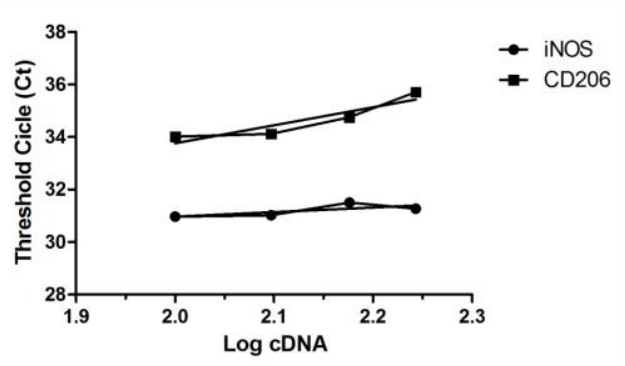

A. Curva padrão de B2M e GAPDH utilizando 10ng, 25ng e 50ng de cDNA. B. Segunda repetição da curva padrão de GAPDH utilizando as mesmas quantidades de cDNA que no painel A. C. Curva padrão dos primers CD86, TH1 e TH2 utilizando 25ng, 50ng e 75ng de CDNA. D. Curva padrão dos primers iNOS, Arginase-1 e CD206 com 25ng, 50ng e 75ng de cDNA. E. Segunda tentativa de padronização dos primers iNOS e CD 206, utilizando 100ng, $125 \mathrm{ng}, 150 \mathrm{ng}$ e $175 \mathrm{ng}$ de cDNA. Para cada reação, foram utilizados cDNA de SN da mesma amostra teste diluída seriadamente, bem como 400ng de primer. 
Tabela 7. Dados da reta da curva e da eficiência dos primers utilizados

\begin{tabular}{lllll}
\hline Primers & $\mathrm{R}^{2}$ & $1 /$ slope & Eficiência & Repetição \\
\hline B2M & 0,994 & $-0,312$ & 1,052 & \\
GAPDH & 0,933 & $-0,435$ & 1,721 & Primeira \\
GAPDH & 0,999 & $-0,318$ & 1,079 & Segunda \\
CD 86 & 0,996 & $-0,356$ & 1,269 & \\
TH1 & 0,999 & $-0,328$ & 1,129 & \\
TH2 & 0,994 & $-0,326$ & 1,120 & \\
iNOS & 0,10 & $-0,896$ & 6,878 & Primeira \\
iNOS & 0,575 & 0,572 & $-0,732$ & Segunda \\
Arg-1 & 0,978 & $-0,351$ & 1,241 & \\
CD 206 & 0,897 & $-0,173$ & 0,489 & Primeira \\
CD 206 & 0,844 & 0,146 & $-0,286$ & Segunda \\
\hline
\end{tabular}

A partir das análises da curva padrão e da eficiência foram escolhidos TH1, CD86, Arginase-1, B2M e GAPDH para serem utilizados na técnica de RTPCR.

3.5.3. Expressão gênica de Arginase-1, CD86 e Tirosina Hidroxilase na SN em função do tempo após a indução de DP

Dentre os normalizadores B2M e GAPDH, foi escolhido o GAPDH como o controle endógeno para calcular os $\triangle \mathrm{Ct}$ dos genes TH, CD86 e Arg-1, uma vez que não houve variação superior a $2 \mathrm{Cts}$ entre os lados controle e tratado dos animais WT e KO. Além disso, a média dos valores referentes ao lado controle (esquerdo) de cada grupo de animal e de cada dia avaliado foi considerado o valor de referência para o cálculo do fold change ( $\left.2^{-\Delta \Delta C t}\right)$.

Os gráficos da figura 18 apresentam as expressões dos genes de TH, CD 86 e Arginase-1 no lado com 6-OHDA nos dois animais analisados. Quanto ao gene $T H$, não houve interação entre o genótipo e os dias pós-cirúrgicos (ANOVA de duas vias; $\mathrm{p}=0,34 ; \mathrm{F}(7,19)=1,17)$, indicando que não houve influência desses fatores na quantificação da sua expressão (gráfico $A$ da figura 13). Observa-se um aumento marginalmente signifcativo da expressão do gene $T H$ no dia 9 nos WT em relação aos $\mathrm{KO}$, porém a variação interindividual foi alta, impossibilitando uma conclusão mais acurada desse resultado $(p=0,063 ; F(7,19)=3,89)$. 
Da mesma forma que para o gene de $\mathrm{TH}$, não houve interação entre o genótipo e os dias após a cirurgia para a expressão gênica da Arginase-1 (ANOVA de duas vias, $p=0,11 ; F(7,19)=2,29)$. Também foi observada variação interindividual nos dias especificados, o que dificulta a análise dos dados (gráfico B). Contudo, após 15 dias da indução da DP, verificou-se um aumento significativo no lado experimental dos WT em relação aos $K O(p=0,04 ; F(7,19)=4,65)$, indicando que nesse período há uma tentativa de recuperação do tecido lesionado nos WT.

Em relação ao gene $C D 86$, houve interação entre os fatores considerados (ANOVA de duas vias; $p=0,03 ; F(7,23)=3,57$ ), indicando que a expressão de CD86 difere entre os genótipos nos dias analisados após a cirurgia. De acordo com o gráfico $\mathrm{C}$, verificou-se um aumento significativo no lado tratado com 6-OHDA dos KO quando comparados aos WT em todos os dias considerados (Para 3 dias, $p=0,003$; $F(7,23)=10,82$; Para 6 dias, $p=0,026 ; F(7,23)=5,65$; Para 9 dias, $p=5,86 \times 10^{-7}$; $F=46,55$; Para 15 dias, $p=0,001 ; F(7,23)=14,32)$. Além disso, o pico de expressão de CD86 nos KO foi com 9 dias, uma vez que esse valor foi significativamente superior que os valores de 6 e 15 dias ( $p=0,001$ para a comparação entre 6 e 9 dias, bem como para 9 e 15 dias). 
Figura 18. Gráficos das expressões gênicas de TH, CD86 e Arg-1 na SN dos animais WT e KO em função dos períodos de 3, 6, 9 e 15 dias após a injeção de 6OHDA

A.

TH

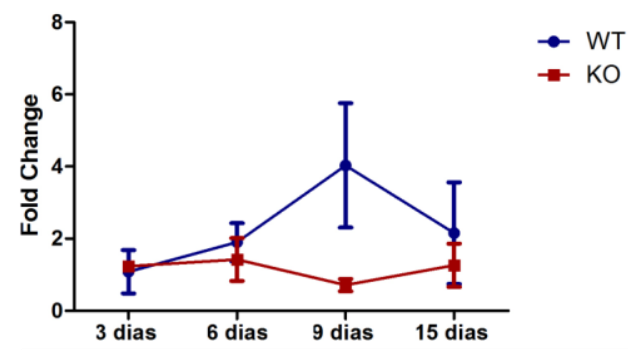

C.

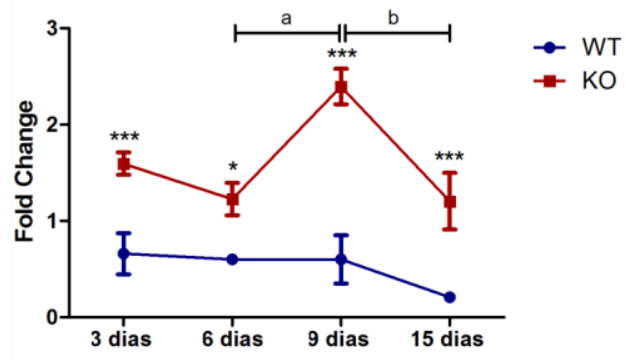

B.

Arginase-1

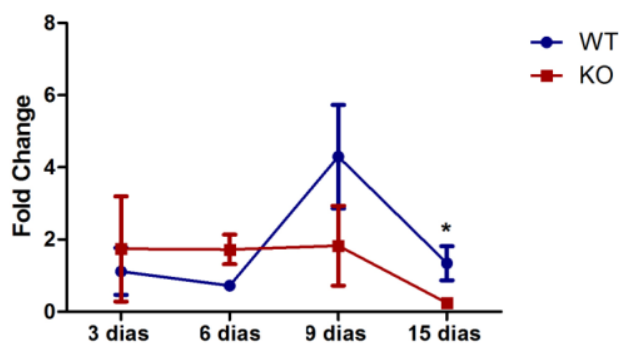

Todas as reações foram realizadas com 50ng de cDNA e 400ng de cada primer, bem como os resultados do fold change foram calculados tendo como controle a média do lado esquerdo (veículo) dos animais de cada grupo referente a cada dia. A. Os camundongos WT e KO apresentam o mesmo nível de expressão gênica de TH nos quatro períodos de tempo analisados. B. Aumento da expressão gênica de Arginase-1 nos WT em comparação com os KO apenas após 15 dias de indução de DP. C. Aumento da expressão gênica de CD86 nos $\mathrm{KO}$ em relação aos WT em todos os períodos de tempo analisados, sendo que o pico foi com 9 dias. ${ }^{*} \mathrm{p}<0,05 ;{ }^{* * *} \mathrm{p}<0,001$, a refere-se a comparação entre 9 e 6 dias com $p=0,001, b$ refere-se a comparação entre 9 e 15 dias com $p=0,001$. Esses gráficos apresentam média \pm desvio padrão de 4 animais de cada grupo.

\subsection{Análise das lesões no DNA nuclear e mitocondrial da SN}

O mecanismo de ação da 6-OHDA está relacionado com o aumento de EROs tanto intracelular quanto extracelular, bem como com o bloqueio dos complexos I e IV mitocondriais (35) e dos sistemas antioxidantes (34). Dessa forma, a geração de EROs em grandes quantidades no parênquima cerebral pode levar a lesões no DNAmt e DNAn, comprometendo a homeostase neuronal e consequentemente, impossibilitando a sua sobrevivência. 
Visando verificar se a ausência da Nox2 influencia a redução da quantidade de lesões no DNAmt e DNAn, foram analisadas as amplificações relativas de cada organela por meio do PCR de longa extensão. Essa técnica baseia-se no princípio de que lesões no DNA levam ao bloqueio da DNA polimerase, reduzindo a eficiência da amplificação dos fragmentos longos (101). Esses experimentos foram realizados no laboratório de genética mitocondrial da Profa. Dra. Nadja C. de Souza-Pinto do Instituto de Química da USP.

Os resultados da amplificação do DNAn estão apresentados nos painéis $A$ e $B$ da figura 19. Os dois fatores analisados, genótipo e tratamento com 6-OHDA, não apresentaram interação entre si (ANOVA de duas vias; $p=0,72 ; F(3,12)=0,127$ ) e não foram signifcativos quando analisados individualmente. De acordo com 0 gráfico, não houve diferença significativa entre os lados esquerdo (veículo) e direito (6-OHDA) nos dois genótipos (ANOVA de duas vias; Para WT, $p=0,99 ; F(3,12)=$ $3,4 \times 10^{-5}$; Para $\left.\mathrm{KO}, \mathrm{p}=0,62 ; \mathrm{F}=(3,12)=0,24\right)$, bem como, não foi observada diferença entre os genótipos quando os lados correspondentes foram comparados (ANOVA de duas vias; Para o lado esquerdo, $p=0,88, F(3,12)=0,02$; Para o lado direito, $p=0,52$, $F(3,12)=0,43)$.

Já para as lesões referentes ao DNAmt, os resultados estão expostos nos painéis $C$ e D. Assim como para o DNAn, não foi observada interação entre os fatores analisados (ANOVA de duas vias, $p=0,078 ; F(3,12)=3,72$ ). Como pode ser observado no gráfico $\mathrm{D}$, o lado controle (CTRL) dos KO apresentou uma amplificação relativa superior ao lado controle dos WT, o que pode ser um indicativo de que a ausência de NOX2 leva a redução de lesões no DNAmt em condições normais, ou seja, esse DNA está menos exposto à danos causados pela liberação de EROs (ANOVA de duas vias; Para o lado esquerdo, $p=0,06 ; F(3,12)=4,25 ;$ Para 0 lado direito, $p=0,51, F(3,12)=0,44)$. Além disso, foi verificada uma redução dos produtos de amplificação quando comparado o lado direito e esquerdo dos $\mathrm{KO}$, indicando que a presença da droga aumenta as lesões no DNAmt, possivelmente em virtude da elevação de EROs. Porém, essa diferença não foi significativa. (ANOVA de duas vias, Para KO, $p=0,079, F(3,12)=3,69$; Para WT, $p=0,43$, $F(3,12)=0,65)$. 
Figura 19. Análise da presença de lesões no DNA nuclear e mitocondrial em amostras de SN de animais WT e KO tratados com veículo ou 6-OHDA.

A.

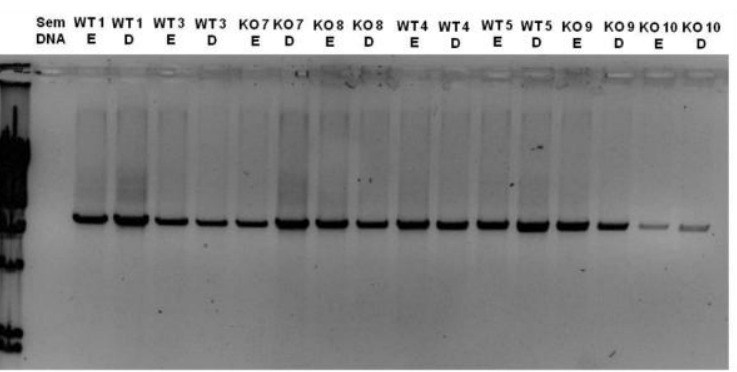

C.

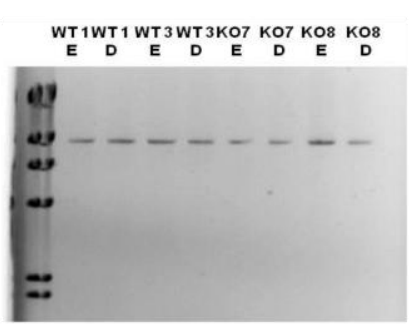

B.

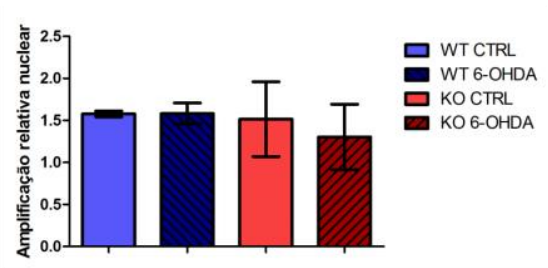

D.

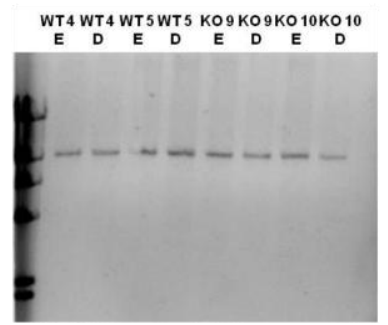

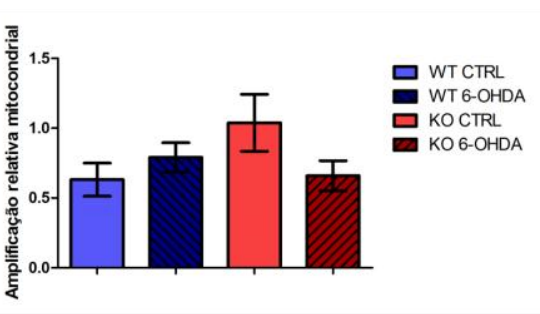

Essa análise foi realizada por meio da técnica de PCR de longa extensão. A. Gel de agarose $1 \%$ mostrando os fragmentos longos nucleares das amostras utilizadas, sendo que a letra $E$ representa o lado esquerdo que foi tratado com veículo e a letra $\mathrm{D}$, o lado direito tratado com 6-OHDA. B. Gráfico das amplificações relativas nucleares, evidenciando que os grupos analisados não apresentaram diferenças significativas na quantificação desse tipo de lesão. C. Gel de agarose 1\% com os fragmentos longos mitocondriais das amostras utilizadas. D. Gráfico das amplificações relativas mitocondriais, mostrando aparentemente que o grupo KO CTRL apresenta menos lesões no DNA que os WT CTRL, embora essa diferença não seja significativa. $\mathbf{W T}=$ wild type; $\mathbf{K O}=$ knockout; $\mathbf{E}=$ lado esquerdo (veículo); $\mathbf{D}=$ lado direito (6-OHDA). Os números posteriores ao WT e KO nos géis são correspondentes à identificação dos animais utilizados. Foram realizados dois experimentos independentes em duplicata na análise de DNAn e um experimento em duplicata na análise do DNAmt.

\subsection{Resumo dos resultados}

\section{Resultados}

\begin{tabular}{ll}
\hline Naïve - Marcação & CPu: KO > WT \\
de Iba-1 & SNpc: KO > WT
\end{tabular}

Naïve - Marcação $\quad$ CPu: KO > WT




\begin{tabular}{ll}
\hline de iNOS & SNpc: KO > WT \\
\hline Teste do cilindro & Piora da performance em função do tempo no \\
WT (14 dias mais comprometido que 7 dias) & WT apresentou desempenho inferior em \\
relação ao KO nos dois dias analisados
\end{tabular}

\begin{tabular}{lc}
\hline Relações entre WT & CPu TH: Redução temporal no WT e KO (15 \\
e KO & dias $<3$ dias) \\
imunohistoquímica & CPu lba-1: Redução temporal no WT (15 dias \\
$<3$ dias) & 3 dias: KO $<$ WT \\
CPu iNOS: \\
SN TH: Redução temporal no WT (15 dias <3 \\
dias) \\
15 dias: KO > WT \\
SN Iba-1: 3 dias: KO > WT \\
SN iNOS: 3 dias: KO > WT \\
TH: Não houve diferença significativa temporal \\
no WT e no KO \\
Arginase-1: 15 dias: WT > KO \\
CD86: KO $>$ WT em todas os dias analisados \\
\hline
\end{tabular}




\begin{tabular}{lcc}
\hline & KO: pico em 9 dias & \\
\hline PCR de longa & DNAn: Não houve diferença entre os lados no \\
extensão & WT e no KO \\
& DNAmt: KO CTRL $>$ WT CTRL \\
& (marginalmente significativo) \\
& KO 6-OHDA $<$ KO CTRL (marginalmente \\
& significativo)
\end{tabular}




\section{DISCUSSÃO}

O presente trabalho propôs investigar os efeitos da ausência da Nox2 na modulação da resposta microglial durante a progressão da neurodegeneração dopaminérgica causada pela 6-OHDA. Como a Nox2 é fundamental para a modulação fenotípica microglial, observou-se que os camundongos $\mathrm{KO}$ naïves apresentaram um aumento tanto do número de células microgliais quanto de células que expressam iNOS em relação ao grupo controle. A indução de DP por meio de injeções unilaterais de 6-OHDA gerou diferenças nas habilidades motoras em função do tempo nos animais selvagens, sendo que os KO não apresentaram déficit motor em função do tempo como observado no WT. Essa diferença comportamental foi decorrente da significativa perda neuronal verificada nos WT e não evidenciada nos $\mathrm{KO}$, bem como nas diferenças da ativação microglial entre os dois animais no período de 3 dias. Análises temporais da expressão gênica de marcadores microgliais, como Arg-1 e CD86, mostraram que essas proteínas variam diferentemente entre os dois genótipos em função do tempo de exposição com a neurotoxina. Além disso, foram verificados os níveis de lesões oxidativas no DNAn e DNAmt nos lados controles e com 6-OHDA nos dois grupos de animais e foi observado que os camundongos gp $91^{\text {phox-l- }}$ apresentaram menos lesões no DNAmt em relação aos controles, possivelmente em virtude da redução de dano oxidativo causado pela produção de EROs via Nox2.

No estudo de Hernandes e colaboradores (95), os autores verificaram que a SNpc dos camundongos naïves gp9 $1^{\text {phox-l- }}$ apresentaram uma quantidade superior de células marcadas com OX42 (CD11b), um marcador de microglia ativada (52), quando comparado com os animais selvagens. Por outro lado, foram utilizados no presente estudo os anticorpos anti-lba-1 e anti-iNOS, sendo que o primeiro detecta microglia nos estados de repouso (ramificada), de ativação e fagocítico (ameboide) (54) e o segundo identifica a ativação da enzima óxido nítrico sintase induzível presente na microglia pró-inflamatória. Assim, foi necessário verificar nos camundongos naïves a expressão dessas proteínas com o intuito de averiguar se a ausência da Nox2 altera os seus níveis basais. Os resultados corroboraram com o estudo anterior (95), uma vez que mostraram que os KO apresentam um número significativamente maior de microglias tanto na SNpc quanto no CPu em relação aos 
WT, indicando que a ausência do gene $C Y B B$ leva a proliferação de microglias nas duas regiões analisadas.

Além disso, foi observado um aumento no nível basal da ativação da enzima iNOS, sendo que esta enzima somente é expressa em células gliais na presença de estímulos específicos como a presença de produtos provenientes de bactérias, vírus e de citocinas pró-inflamatórias como IL-1 $1 \beta$ e IFN-Y (105). Na doença granulomatosa crônica (CGD), causada pela ausência da produção de EROs pela Nox2, observouse que os pacientes apresentaram uma hiper-inflamação sem a presença de agentes infecciosos em diferentes tecidos, fato que pode estar relacionado à deficiência da resolução da inflamação por meio da produção de EROs. A produção de EROs exerce um papel fundamental na degradação de materiais fagocitados, bem como, contribui para a resolução da inflamação por meio da supressão de sinais pró-inflamatórios ou por meio da redução de células pró-inflamatórias. Logo, defeitos nesses processos podem levar a um agravamento da inflamação (106). Diante desse fato, sugere-se que o aumento da ativação de iNOS verificada nos KO a nível basal pode ser proveniente da resposta glial frente ao comprometimento da inativação oxidativa de mediadores pró-inflamatórios e/ou da redução da degradação de materiais fagocitados.

A ativação microglial tem sido identificada em modelos de doenças neurodegenerativas, como a DP e a DA, em períodos que antecedem o processo de morte neuronal e da manifestação dos sintomas característicos (103, 104, 107). Como os estudos anteriores que analisaram o processo de neurodegeneração dopaminérgica utilizando a 6-OHDA foram realizados em ratos (103) ou em camundongos fêmeas (104), bem como utilizaram doses da droga maiores que a utilizada no presente estudo $(10 \mu \mathrm{g}$ e $12 \mu \mathrm{g})$, fez-se necessário a análise do perfil de ativação microglial nos dois genótipos em função do processo neurodegenerativo, sendo selecionados os períodos de 3 e 15 dias após a cirurgia.

O período de 3 dias foi escolhido em virtude da ativação das subunidades p4 $7^{\text {phox }}$ e gp91 ${ }^{\text {phox }}$ da Nox2 ocorrerem após 48 horas da entrada da droga (25), o que levou ao questionamento se a ausência da ativação da Nox2 nesse período alteraria o processo de ativação microglial nos $\mathrm{KO}$ e, por conseguinte, a neurodegeneração. A partir das análises da densidade celular da marcação do anticorpo anti-TH no $\mathrm{CPu}$, observou-se que não houve uma redução significativa no lado experimental tanto nos selvagens quanto nos nocautes. Esses resultados diferem com os 
achados de Stott e Barker (2014) que identificaram significativa redução de terminais dopaminérgicos no estriado após 1 dia de lesão. Essa divergência dos resultados pode ser decorrente da diferença entre as doses da droga, uma vez que os autores citados utilizaram o dobro de dose de 6-OHDA.

Com relação à ativação microglial nessa estrutura e nesse período de tempo, foi observado aumento significativo de células lba-1+ no lado lesionado nos dois grupos de animais. Essa proliferação de células microgliais sem a perda significativa de terminais dopaminérgicos pode ser decorrente do aumento de debris celulares causados pela ação da neurotoxina. A partir da ativação da microglia, a liberação de mediadores pró-inflamatórios como TNF- $\alpha$, IL-1 $\beta$ e IFNy, isoladamente ou não, contribuem para indução de iNOS na microglia e nos astrócitos $(105,108)$. Essa enzima regula o número de fenótipos M1 e M2 de macrófagos, influenciando na ativação do tipo M1 (109). Assim, pode-se sugerir que o aumento da expressão de iNOS no CPu dos WT ocorreu devido à ativação da microglia possivelmente para o fenótipo M1.

As quantificações referentes à SNpc dos dois grupos foram semelhantes às encontradas no $\mathrm{CPu}$, exceto pelo aumento significativo de células $\mathrm{lba}-1+$ ser verificado apenas nos KO. Assim, não foi observada redução significativa de neurônios dopaminérgicos com 3 dias de lesão, o que difere novamente dos achados de Stott e Barker (104) que relataram uma redução de 86,4\% entre os dias 1 e 3 de exposição a droga. Já com relação à ativação microglial em animais WT, estudos observaram seu início a partir de 3 dias, atingindo significância com 7 ou 9 dias após a lesão tanto a partir da quantificação do comprimento dos braços celulares e do número de endpoints microgliais quanto do número de células ((103, 104). Os resultados expostos aqui estão em concordância com esses achados. Entretanto, apesar de não ser encontrada diferenças no número de células lba-1+ nos WT, observou-se uma expressiva ativação de iNOS. Possivelmente, esse aumento da expressão deve-se à ativação dessa enzima nos astrócitos, já que não houve alteração do número de microglias. Por outro lado, a resposta microglial nos KO foi diferente dos WT, uma vez que ocorre na SNpc. Isso pode ser devido a pouca quantidade de droga que atinge esse núcleo basal ser suficiente para aumentar a proliferação e ativação microglial, uma vez que o parênquima cerebral dos animais naïves já se encontrar hiper-inflamado. 
Com relação aos animais WT submetidos à perfusão após 15 dias da cirurgia, foi observado no lado com 6-OHDA os seguintes resultados: a redução significativa dos terminais dopaminérgicos no CPu e dos neurônios marcados com TH na SNpc, o aumento significativo da ativação microglial nas duas estruturas e o aumento da marcação de iNOS apenas na SNpc. A porcentagem de células positivas para TH na SNpc desses animais foi de $38,96 \%( \pm 24,21)$ em relação ao lado controle, sendo que foi observada a presença de $54,4 \%( \pm 2,8)$ de células marcadas com $\mathrm{TH}$ em fêmeas após 12 dias da lesão com 6-OHDA (104). Como comentado anteriormente, a ativação microglial na SNpc foi verificada apenas 9 dias após a injeção da droga(103, 104), sendo que os resultados obtidos com a densidade celular do anticorpo lba-1 com 15 dias corroboram com essas informações.

Assim como observado para os WT após 15 dias de indução de DP, os camundongos $\mathrm{KO}$ apresentaram os mesmos resultados nas duas estruturas e nas três proteínas analisadas. A redução significativa de terminais e neurônios dopaminérgicos verificados nos gp9 $1^{\text {phox-l- }}$ após 15 dias diferem dos resultados descritos por Hernandes e colaboradores (93), em que a quantidade de células positivas para $\mathrm{TH}$ no $\mathrm{CPu}$ e na SNpc não diferem entre o lado experimental e controle nos nocautes, não havendo, portanto, perda neuronal com a injeção da droga. Além disso, o aumento significativo de células Iba-1+ observado no lado com 6-OHDA nas duas estruturas dos KO também diferem dos resultados desses autores, uma vez que não houve aumento de microglias marcadas com OX42 (CD11b) no lado experimental no mesmo período após a injeção da neurotoxina.

Com relação ao aumento da ativação de iNOS na SNpc dos WT e dos KO, pode-se afirmar que após 15 dias de lesão, ainda há a liberação de citocinas próinflamatórias e a ativação da microglia para o fenótipo M1, possivelmente em virtude da quantidade de dano celular causado pela droga com grande quantidade de debris celulares que precisam ser fagocitados. No modelo de MPTP, foi observado aumento significativo de expressão de iNOS em células microgliais após 4 dias de injeção da toxina, retornando aos níveis basais após 7 dias. Também foi relatado que a presença da enzima iNOS acelera o processo de morte neuronal causada pela droga, uma vez que são gerados ERNs que reagem com EROs formando espécies como o peroxinitrito ( $\left.\mathrm{ONOO}^{-}\right)$, que são altamente tóxicas para o neurônio (110). 
Quando foram analisadas as relações entre os lados experimentais e controles dos KO em comparação com os WT, foram identificadas algumas diferenças entre os padrões do processo neurodegenerativo e da ativação microglial nas regiões analisadas. No $\mathrm{CPu}$, os dois genótipos apresentaram redução significativa de terminais dopaminérgicos em função do tempo, evidenciando que a progressão do processo neurodegenerativo no CPu é semelhante no WT e no KO. Apesar de ser evidenciada neurodegeneração progressiva nos dois grupos, a resposta microglial foi distinta, uma vez que o número de células lba-1+ foi significativamente superior nos WT no período de 3 dias em relação aos KO. Entretanto, essa alta taxa de células microgliais é reduzida em função do tempo com redução no período de 15 dias.

$\mathrm{Na} \mathrm{SNpc}$, a quantificação dos neurônios dopaminérgicos nos dois grupos de animais mostrou que há uma progressão do processo neurodegenerativo nos WT, com redução significativa no período de 15 dias em relação ao de 3 dias, enquanto que essa progressão não foi observada nos $\mathrm{KO}$, em que as porcentagens das relações nos dois dias não são diferentes estatisticamente. Ademais, a porcentagem de neurônios dopaminérgicos no lado experimental dos camundongos $\mathrm{KO}$ foi significativamente superior ao dos WT, indicando que apesar da aparente redução dos neurônios entre os lados experimental e controle, houve algum mecanismo de neuroproteção que impediu que houvesse a progressão do processo neurodegenerativo. Com relação à ativação microglial e expressão de iNOS, verificou-se um aumento da presença de células lba-1+ e iNOS+ nos KO em relação aos WT apenas no período de 3 dias, mostrando que esses animais apresentam diferenças temporais na ativação microglial, sendo portanto, precoce nos $\mathrm{KO}$.

A liberação de $\mathrm{O}_{2}{ }^{--}$e de $\mathrm{NO}$ a partir da ativação da Nox2 microglial e da enzima iNOS leva a formação de ONOO', espécie mais neurotóxica que as duas que a originaram. Mander e Brown (111) mostraram a partir de co-culturas de neurônios granulares cerebelares e glia que a morte neuronal ocorre apenas quando há a ativação simultânea das enzimas Nox e iNOS, não sendo evidenciada morte neuronal significativa quando uma das enzimas é inibida ou quando é utilizado um composto que decompõe o ONOO- Além disso, camundongos $\mathrm{iNOS}^{-/}$que receberam doses de MPTP para indução de DP apresentaram resistência à droga, com sobrevivência do dobro de neurônios em relação aos WT (110). Baseado nessas informações pode-se inferir que a neuroproteção dos gp $91^{\text {phox-l- }}$ em relação 
aos WT é decorrente da ausência de formação de ONOO', visto que esses animais não liberam $\mathrm{O}_{2}{ }^{\circ-}$ pela ativação de Nox2.

Uma das primeiras metodologias utilizadas para avaliar o comprometimento motor causado pela indução unilateral de 6-OHDA em ratos foi o teste rotacional utilizando drogas como a anfetamina e a apomorfina (112). Entretanto, estudos mostraram que o uso de drogas psicoestimulantes pode alterar a eficiência sináptica principalmente na porção de neurônios médios espinhosos que integram a sinalização entre a dopamina e o glutamato (113). Além disso, o uso de altas doses de apomorfina pode causar comportamentos estereotipados e redução da resposta rotacional do camundongo (114). Logo, aumentou-se a preferência na utilização de testes comportamentais livres da administração de drogas, como por exemplo, o teste do cilindro. O teste do cilindro ou do uso assimétrico dos membros mostrou-se confiável no modelo unilateral de 6-OHDA tanto em ratos quanto em camundongos, evidenciando a redução do uso do membro contralateral com o aumento da perda de neurônios dopaminérgicos $(99,115,116)$. Um estudo comparando vários testes comportamentais livres da administração de drogas em camundongos submetidos à 6-OHDA no feixe medial do prosencéfalo revelou que o teste do cilindro é reprodutível e confiável para a avaliação de déficit motor nesse modelo (115), além de ser fácil de ser realizado e não precisar de treinamento antes da sua execução. Além disso, Heuer e colaboradores (116) mostraram que o teste do cilindro correlaciona-se principalmente com a lesão de 6-OHDA no CPu de camundongos, sendo preciso em detectar os animais com lesão expressiva.

De acordo com os resultados do teste do cilindro nos dois grupos de animais do presente estudo, verificou-se uma redução temporal significativa do uso do membro contralateral a lesão nos animais WT, evidenciando o comprometimento motor associada à perda neuronal dopaminérgica em função do tempo da administração da neurotoxina. Esses dados corroboram com os de Glajch e colaboradores (115) que também verificaram a redução progressiva e significativa do uso do membro contralateral a partir da segunda semana da injeção de 6-OHDA quando comparados com animais submetidos à injeção bilateral de salina.

Com relação aos resultados dos $\mathrm{KO}$, estes não apresentaram diferenças significativas na média do uso do membro contralateral em função do período póslesão, indicando que não houve comprometimento motor ao longo do tempo e que a perda de neurônios $\mathrm{TH}+$ não foi expressiva o suficiente para causar déficit. Ademais, 
a diferença entre o desempenho do KO e WT foi significativa nos dias 7 e 14 após a lesão, mostrando que os camundongos WT apresentaram um prejuízo motor significativo em relação aos KO. Hernandes e colaboradores (95) também observaram essa diferença entre os WT e KO no teste rotacional com apormorfina, em que o número de rotações por minuto foi significativamente menor nos KO.

A análise da expressão gênica em 4 dias distintos após a cirurgia com 6-OHDA (3, 6, 9 e 15 dias) mostrou que não houve diferença significativa na quantidade de RNA mensageiro (RNAm) de tirosina hidroxilase entre os genótipos. Diferentemente, o trabalho de NA e colaboradores (117) analisaram a expressão de TH em ratos submetidos a 6-OHDA por meio da técnica de microarray e observaram uma redução do fold change a partir do sétimo dia, sendo considerado um gene regulado negativamente.

Com relação à expressão do gene $C D 86$, verificou-se aumento significativo desse gene nos KO em relação aos WT, atingindo um pico de expressão no dia 9 após a cirurgia. Assim, esse dado sugere que o fenótipo M1 microglial é predominante nos $\mathrm{KO}$ em relação aos WT em todo o processo neurodegenerativo. Segundo Chhor e colaboradores (118), a expressão do gene CD86 apresenta-se elevada após 4 horas em culturas de microglia induzidas para o fenótipo M1. Como nesse estudo não foi realizado o isolamento das células microgliais da estrutura cerebral para a posterior análise molecular, os resultados obtidos representam a expressão desse gene em macrófagos infiltrantes e microglia (119), bem como em linfócitos B e T e astrócitos (120).

Quanto à expressão de Arginase-1, os animais WT apresentaram uma elevação da expressão desse gene após 15 dias da lesão em relação aos KO, apesar da grande variação entre os indivíduos utilizados no experimento. Quando a Arginase-1 é ativada, ocorre a produção de ornitina a partir do substrato L-Arginina, que também consiste no substrato de iNOS. Ornitina é importante na produção de glutamato, prolina, hidroxiprolina e poliaminas, sendo fundamentais em processos de proliferação celular, diferenciação e neurogênese (121). Assim, pode-se inferir que após 15 dias esteja ocorrendo algum processo anti-inflamatório e de reparo do tecido lesionado nos WT, sendo quase inexpressivo nos KO. Os resultados obtidos com os KO não corroboram com os dados de Choi e colaboradores (122) que verificaram o aumento da expressão de Ym1 e IL-4Ra nesses animais quando submetidos à injeção intracerebroventricular de lipopolissacarídeo (LPS). Esse 
mesmo estudo demonstrou que tanto a inibição farmacológica com apocinina quanto a deleção do gene de Nox2 influenciam a mudança da microglia para um fenótipo M2.

Um dos mecanismos de ação da 6-OHDA consiste no bloqueio dos complexos I e IV mitocondriais, levando ao aumento da liberação de EROs e consequentemente a danos à biomoléculas, como o DNA (35). Quando o DNA sofre dano oxidativo e não é reparado pela célula, pode ocorrer instabilidade genética e proteica, tornando-a mais susceptível ao processo de morte. Assim, o acúmulo de danos oxidativos no DNA nuclear e mitocondrial somado a baixa renovação celular tornam-se eventos deletérios ao neurônio (123). Apesar de existirem poucos estudos nessa área relacionados à DP, um trabalho analisou 8 regiões cerebrais de indivíduos com DP e observou que o mesencéfalo foi a região que apresentou maior número de quebras de fita dupla e simples no DNAn em relação aos controles, além de alterações conformacionais e de estabilidade estrutural (124).

Baseado nessas informações, foram verificados os níveis de lesões no DNAn e DNAmt que são capazes de bloquear a progressão da DNA polimerase na SN de animais WT e KO submetidos à 6-OHDA. De acordo com os resultados obtidos, o lado controle do WT apresentou um aumento do nível de lesão no DNAmt quando comparado ao mesmo lado do $\mathrm{KO}$, evidenciando que a ausência da enzima Nox2 reduz os níveis de EROs na célula, e por conseguinte, o DNAmt fica mais protegido do dano oxidativo. Além disso, foi observado que a presença da 6-OHDA nos KO elevou os níveis de lesões no DNAmt quando comparado com o respectivo controle, indicando que a 6-OHDA consiste em uma fonte de produção de EROs e altamente neurotóxica à células neuronais. Dessa forma, esses resultados mostram que o DNAmt é mais vulnerável ao dano oxidativo em um modelo de DP e que a ausência da enzima Nox2 auxilia na proteção dessa biomolécula, uma vez que reduz a produção de EROs. O estudo de Sanders e colaboradores (125) demonstrou a ocorrência de sítio abásicos (AP) no DNAmt de neurônios dopaminérgicos tanto em amostras post-mortem quanto em ratos submetidos à rotenona, não sendo observado nos neruônios corticais. No modelo animal, a ocorrência dos AP antecede a morte neuronal e é resultante da resposta desses neurônios frente ao bloqueio do complexo I, o que levou os autores a sugerirem como marcador molecular da neurodegeneração dopaminérgica a presença de AP no DNAmt. 
Portanto, a investigação da modulação microglial via ativação da Nox2 na progressão do processo neurodegenerativo do modelo de 6-OHDA contribuiu para a melhor compreensão do papel da microglia nos mecanismos envolvidos na morte neuronal dopaminérgica. A partir da neuroproteção observada nos camundongos gp9 $1^{\text {phox-l- }}$, pode-se inferir que os neurônios dopaminérgicos ficam mais susceptíveis à morte celular causada pelo aumento de EROs quando ocorre a ativação simultânea das enzimas iNOS e Nox2 nas células microgliais. Além disso, os resultados também demonstraram a importância da Nox2 na mudança do perfil microglial durante o processo neurodegenerativo, bem como na redução das lesões no DNAmt. 
Capítulo 2. Depleção microglial acelera a disfunção motora e a perda de neurônios dopaminérgicos em modelo de doença de Parkinson usando 6-hidroxidopamina 


\section{INTRODUÇÃO}

Uma maneira de compreender a biologia da microglia e sua função em doenças neurodegenerativas é por meio da manipulação do seu número no SNC. O receptor CSF1R (Colony-stimulating factor 1 receptor) é amplamente expresso em células de linhagem mielóide e desempenha um papel importante no desenvolvimento e na sobrevivência desse tipo celular $(126,127)$. Os dois ligantes conhecidos desse receptor são CSF-1 e IL-34 (128). O tratamento com o inibidor de CSF1R/c-kit (PLX3397) mostrou a eliminação completa da microglia dentro de 7 a 21 dias (129). Entretanto, quando o inibidor foi removido, células microgliais repopularam o encéfalo inteiro, apresentando o mesmo número de células documentado anteriormente ao processo de depleção. Esse método foi utilizado com o intuito de compreender o impacto da redução microglial em modelos murinos da $\mathrm{DA}(130,131)$. A redução de $30 \%$ no número de microglias em camundongos 3xTgAD evitou a associação da microglia com as placas amilóides, indicando que a inibição do CSF1R altera o fenótipo microglial (130). Outro estudo demonstrou que a eliminação de 80 a $90 \%$ de células microgliais no camundongo 5xTgAD não interferiu nos níveis de $\beta$-amilóide, entretanto, levou a regeneração de espinhos dendríticos em formato de cogumelo na região CA1, bem como preveniu a perda neuronal no subiculum (131).

Estudos anteriores do nosso laboratório demonstraram que a administração de 6-OHDA em camundongos gp91 $1^{\text {phox-l- }}$ não apresentaram comportamento relacionado à DP e nem perda significativa neuronal dopaminérgica, evidenciando o papel fundamental que a Nox2 exerce na perda neuronal induzida pela toxina (95). Em contrapartida, o tratamento com minociclina nesses camundongos inibiu os efeitos protetores da ausência de Nox2, enquanto que nos camundongos WT submetidos à 6-OHDA evidenciou-se a proteção neuronal. A minociclina consiste em uma tetraciclina de segunda geração semi-sintética, uma droga anti-microbial relacionada aos efeitos anti-inflamatórios e à inibição da ativação microglial (132, 133). Além disso, algumas citocinas e quimiocinas tanto no $\mathrm{CPu}$ quanto na $\mathrm{SN}$ nos animais com e sem o tratamento de minociclina foram analisadas. Os resultados mostrararam que o tratamento aumentou a produção de TNF- $\alpha$ na SN dos camundongos gp91 ${ }^{\text {phox-l- }}$ submetidos a 6-OHDA, porém o mesmo resultado não foi observado nos animais WT induzidos à DP depois do tratamento. Os autores também observaram que o 
tratamento com minociclina nos camundongos gp91 ${ }^{\text {phox-/- }}$ com 6-OHDA potencializou a ativação de NF-kB, que por sua vez, pode induzir a produção de TNF-a. A partir desses resultados, foi postulada a hipótese de que Nox2 desempenha um papel importante na modulação da resposta microglial de resolução inflamatória por meio da via de sinalização TNF- $\alpha / N F-k B(95)$.

A minociclina é um tipo de tetraciclina que previne a morte celular por meio de pelo menos dois mecanismos, sendo estes: 1- redução da imunidade adaptativa e inata; 2- bloqueio da cascata apoptótica (134). Assim, as tetraciclinas reduzem: a ativação microglial; a transcrição de mediadores pró-inflamatórios downstream como a caspase-1; a enzima iNOS e a COX 2. Consequentemente, elas reduzem a liberação da IL-1 $\beta$, do $\mathrm{NO}$ e das prostaglandinas $\mathrm{E}_{2}\left(\mathrm{PGE}_{2}\right)$, que estão associadas à morte celular (revisado em (134)). Entretanto, os mecanismos de inibição e o tipo de fenótipo microglial inibido ainda são desconhecidos (135). Além disso, múltiplos efeitos da minociclina são descritos em neurônios (134), oligodendrócitos (136) e astrócitos (137) tanto in vivo quanto in vitro, mostrando que os efeitos dessa droga não são específicos na microglia.

Um método específico para eliminar microglia no SNC foi descrito em (129). Nesse estudo, o tratamento de 7 dias com PLX3397 (inibidor de CSF1R/c-kit) mostrou que mais de $90 \%$ das microglias foram eliminadas sem mudanças nos níveis basais dos marcadores de astrócitos, oligodendrócitos e neurônios. Além disso, os autores mostraram uma capacidade notável da repopulação microglial após 3 dias de remoção do inibidor. Essas novas células microgliais derivaram da proliferação de células que expressavam nestina ao longo de todo o SNC e não a partir da infiltração de células periféricas no SNC. O número de células microgliais no estágio de repopulação foi semelhante ao observado em camundongos não tratados, sugerindo a regulação precisa da população microglial.

O processo de eliminação microglial seguida pela repopulação em um modelo murino de perda neuronal amenizou várias características da inflamação crônica, como: 1) morfologia microglial, que apresentou redução dos marcadores inflamatórios no estágio da repopulação quando comparado com o lado lesionado; 2) aumento da expressão de proteínas sinápticas, já que a repopulação microglial aumenta o número de PSD45 e de puncta sinaptofisina; 3) melhoria do comprometimento comportamental, camundongos com lesão+repopulação tiveram uma performance no mesmo nível do grupo controle (138). Esses resultados 
mostraram que a eliminação microglial seguida de repopulação poderia ser usada como método terapêutico para aliviar a inflamação crônica causada pelo processo neurodegenerativo.

\subsection{Justificativas e objetivos}

Como relatado anteriormente, a análise do impacto da inibição de células microgliais por meio da utilização de compostos que não apresentam especificidade, como por exemplo, a minociclina, dificulta a compreensão dos papéis desempenhados por essa célula no processo neurodegenerativo da DP. Entretanto, a eliminação microglial usando o método específico como o inibidor CSF1R é mais preciso, uma vez que os efeitos desencadeados são resultantes apenas da redução do número de células microgliais e não da resposta das outras células neurais frente à inibição desse receptor. Portanto, seria possível compreender se a redução da microglia durante os efeitos da 6-OHDA acelerariam a morte neuronal pela toxina e se aumentaria o comprometimento motor. Além disso, esse estudo é importante para entender a modulação da resposta microglial em um modelo de DP.

O objetivo desse capítulo consistiu em elucidar o papel da microglia na morte neuronal dopaminérgica no modelo bilateral de 6-OHDA, bem como determinar o impacto da eliminação microglial na progressão da doença nas regiões do CPu e da SNpc. Também foi caracterizada a função microglial e o comportamento dos animais depois do tratamento com o inibidor do CSF1R. Para isso, foram realizados os seguintes objetivos específicos:

1. Avaliar as habilidades motoras dos animais submetidos às injeções de 6-OHDA e ao tratamento com o inibidor de CSF1R durante a progressão da doença, com a finalidade de verificar se a ausência da microglia altera as respostas motoras.

2. Analisar o impacto da redução do número de microglias na quantificação de terminais e neurônios dopaminérgicos, por meio da quantificação de células Iba-1+e TH+.

3. Avaliar se o tratamento com CSF1R altera a expressão de microglias fagocíticas, ou seja, CD68+, bem como, avaliar a ativação de astrócitos por meio da expressão de dois marcadores, $\mathrm{S} 100 \beta$ e GFAP.

4. Analisar os principais genes envolvidos no processo neurodegenerativo causado pela 6-OHDA e aqueles que são preferencialmente transcritos quando há 
um processo neurodegenerativo com ausência de microglias, por meio da técnica de NanoString. 


\section{MATERIAIS E MÉTODOS}

\subsection{Desenho experimental}

Camundongos C57bl6 com 3 meses de idade foram submetidos à uma ração controle ou suplementada com $1200 \mathrm{mg} / \mathrm{kg}$ de PLX5622 durante 14 dias para eliminar microglia (129). No décimo quarto dia, metade dos animais de cada grupo foi submetida à indução de DP por meio da injeção da neurotoxina 6-OHDA nos dois hemisférios do $\mathrm{CPu}$, enquanto que a outra metade foi submetida ao veículo. Assim, obtiveram-se 4 grupos, sendo eles: dieta controle/veículo, dieta controle/6-OHDA, PLX5622/veículo e PLX5622/6-OHDA (10 animais por grupo). Depois da indução por 6-OHDA, os animais permaneceram com a mesma dieta inicial por mais 17 dias.

Os testes comportamentais foram realizados depois de 4 dias da dieta e no sétimo e décimo quarto dia após as injeções de 6-OHDA ou veículo, com o objetivo de compreender o impacto da eliminação microglial na progressão do comprometimento das habilidades motoras. A figura 20 ilustra 0 desenho experimental desse estudo.

Figura 20. Desenho experimental da eliminação microglial em camundongos C57BI6 submetidos à injeções com 6-OHDA (modelo de DP) ou com veículo (controle).

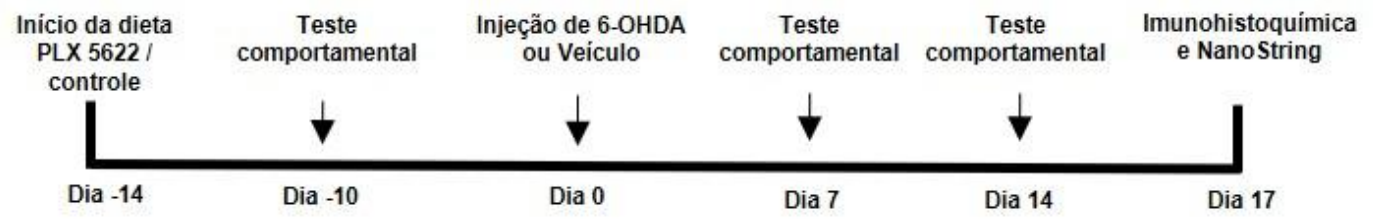

Os animais foram mantidos em um ciclo claro/escuro de 12 horas e a sala foi mantida a $21,1^{\circ} \mathrm{C}$ (variando de $20-23,3^{\circ} \mathrm{C}$ ). Eles foram verificados diariamente com a finalidade de avaliar o bem-estar e a saúde dos animais. Todos os experimentos com os camundongos foram realizados em acordo com o protocolo animal aprovado com o número de AUP-17-179 pelo Institutional Animal Care and Use Committee da Universidade da Califórnia, Irvine (UCI). 
Todos os experimentos apresentados nesse capítulo foram realizados no laboratório do prof. Dr. Kim Green na Universidade da Califórnia em Irvine (CA, EUA).

\subsection{Indução da DP}

Um dia antes dos procedimentos cirúrgicos, os animais receberam Tylenol $(2 \mathrm{mg} / \mathrm{mL})$ na água para a prevenção da dor. Eles foram anestesiados com isoflurano suplementado com $\mathrm{O}_{2}$ via inalação e os procedimentos cirúrgicos só foram iniciados após a certificação de ausência de resposta à estimulação física. Durante todo o procedimento, os animais foram mantidos em contato com uma surperfície quente e a temperatura corpórea foi monitorada com o intuito de evitar a hipotermia. Os camundongos foram colocados em um aparelho estereotáxico com barras especialmente adaptadas para a narina e ouvidos e a craniotomia foi realizada com o auxílio de uma broca. A neurotoxina 6-OHDA (Sigma Chemical Co., St. Louis, MO, USA) foi dissolvida na concentração de $5 \mu \mathrm{g} / \mu \mathrm{L}$ em $\mathrm{NaCl} 0,9 \%$ com $0,1 \%$ de ácido ascórbico (139) e foi injetado $1 \mu \mathrm{L}$ da droga nos dois hemisférios do CPu para promover a lesão retrógrada nos neurônios nigroestriatais (24). A injeção foi realizada usando a seringa Hamilton (modelo $801 \mathrm{~N}$ ) nas seguintes coordenadas: AP:0,4mm; ML: $\pm 2,0 \mathrm{~mm}$; DV: $3,0 \mathrm{~mm}$ em relação ao bregma (96). A agulha permaneceu no lugar da coordenada por 5 minutos antes de ser removida lentamente. Os grupos controles receberam $1 \mu \mathrm{L}$ de veículo (salina com $0,1 \%$ de ácido ascórbico) nas mesmas coordenadas. Após a cirurgia, a pele foi suturada e os animais foram mantidos em caixas isoladas com surperfície quente para promover a recuperação da anestesia. Além disso, os camundongos receberam Tylenol na água durante 48 horas após a cirurgia e sua recuperação pós-operatória foi monitorada diariamente.

\subsection{Teste de campo aberto}

O teste de campo aberto foi utilizado com o objetivo de avaliar a exploração e a atividade locomotora $(97,140)$. Os animais foram habituados na sala, onde foi realizado o comportamento, por 30 minutos e depois foram acomodados individualmente no centro de uma caixa branca opaca (dimensões de $33,7 \mathrm{~cm}$ de comprimento $\times 27,3 \mathrm{~cm}$ de largura e $21,6 \mathrm{~cm}$ de altura) por 5 minutos e 0 comportamento foi gravado. Depois de cada teste, o aparato foi completamente 
limpo com etanol 70\%. O software de rastreamento por vídeo ANY-maze foi usado para medir os seguintes parâmetros: distância percorrida, velocidade média e o tempo gasto tanto no perímetro quanto no centro do campo.

\subsection{Teste do Poste}

O teste do poste tem sido usado em modelos murinos de DP com o intuito de detectar bradicinesia e avaliar a coordenação motora (115, 141). Matsuura e colaboradores (141) mostraram que a dopamina possui uma correlação negativa significante com o tempo de atividade locomotora no teste do poste após 7 dias de indução por 6-OHDA em camundongos.

Este teste comportamental foi dividido em dois dias, sendo que o primeiro correspondeu ao treinamento e o segundo, ao teste. No primeiro dia, os camundongos foram aclimatados na arena por 30 segundos, e depois colocados de cabeça para cima no topo da superfície do poste $(1 \mathrm{~cm}$ de diâmetro $\times 60 \mathrm{~cm}$ de altura) e o tempo que os camundongos levaram para descer o poste e colocar as primeiras patas na arena foi registrado. O treinamento foi repetido 4 vezes com 30 segundos de descanso entre eles. No segundo dia, os camundongos foram colocados 4 vezes por até 5 minutos cada e o tempo também foi documentado. Caso o camundongo escalasse até metade do caminho e depois caísse, o tempo considerado foi até ele atingir a arena. Além disso, quando o camundongo não foi capaz de descer e, ao invés disso, caisse do poste, o tempo registrado foi de 5 minutos.

Esse teste foi realizado em três períodos, sendo eles: antes da cirurgia com 6OHDA, no sétimo e no décimo quarto dia depois da cirurgia. No sétimo e no décimo quarto dia depois da cirurgia, o comportamento foi realizado em 5 tentativas, sendo que a primeira foi considerada o treinamento.

\subsection{Rota rod}

O rota rod consiste em um dos testes comportamentais mais comuns para a avaliação da coordenação motora e do equilíbrio do camundongo (97). Esse teste pode ser realizado em duas maneiras, sendo elas: rota rod com velocidade fixa e rota rod acelerado. Nesse estudo, os camundongos foram testados com velocidade gradualmente acelerada de 4 a $40 \mathrm{rpm}$ até atingir 5 minutos dentro de cada tentativa. Os animais foram colocados no aparato 5 vezes e entre as tentativas eles 
foram colocados em caixas separadas com um intervalo de descanso de 5 minutos. A duração do tempo em que cada animal foi capaz de permanecer na roda foi registrada como o tempo de latência para queda. Além disso, duas razões pelas quais as tentativas foram finalizadas foram registradas, como sendo: queda da roda e duas voltas seguidas ao redor da roda.

\subsection{Imunofluorescência}

Os camundongos foram anestesiados $\operatorname{com} \mathrm{CO}_{2}$ via inalação e submetidos à perfusão transcardíaca com PB. O hemisfério cerebral direito foi coletado, transferido para solução de PFA $4 \%$ e armazenado a $4^{\circ} \mathrm{C}$ durante 2 dias. Depois desse período, os cérebros foram colocados em PB com $0,02 \%$ de azida sódica e $30 \%$ de sacarose por 2 dias para garantir a crioproteção do tecido. O outro hemisfério foi congelado rapidamente em gelo seco para a realização dos procedimentos de isolamento de RNA.

Os tecidos foram cortados em uma espessura de $40 \mu \mathrm{m}$ em um micrótomo deslizante em congelamento. Cortes de SN e CPu foram selecionados e submetidos ao método de imunofluorescência conforme descrito em (142). Os anticorpos utilizados e suas respectivas especificações foram: Iba-1 (policlonal, coelho; Wako, Cat\#019-19741; 1:1000) para detectar microglia; TH (monoclonal, camundongo; Chemicon, Temecula, CA, USA; 1:2000) para detectar neurônios dopaminérgicos; CD68 (Cluster of Differentiation 68, clone FA-11, monoclonal, rato; BioRad, Cat\# MCA1957GA, 1:200) para marcar macrosialina de camundongo;TMEM119 (monoclonal, coelho; Abcam, Cat\#ab209064; 1:200) para marcar microglia; P2RY12 (policlonal, coelho, Sigma, Cat\#HPA014518; 1:200) para marcar microglia homeostática. Além disso, os tecidos também foram marcados com anticorpos GFAP (anti-glial fibrillary acidic protein, policlonal, galinha; Abcam; Cat\#ab4674; 1:5000) e $S 100 \beta$ (policlonal, coelho; Abcam; Cat\#ab41548; 1:200) para marcar astrócitos. Depois das incubações, os cortes foram dispostos em lâminas e cobertas com lamínulas usando Dapi Fluoromount-G (SouthernBiotech).

Imagens do $\mathrm{CPu}$ e SNpc foram obtidas a partir do microscópio Zeiss Axiolmager M2, utilizando o pacote de software Stereo Investigator do MicroBrightField. 


\subsection{Isolamento de RNA}

Antes do início da extração de RNA, as superfícies e todos os equipamentos utilizados no procedimento foram limpos com RNAse Zap (\#00554172, Thermo Fisher). A SN foi microdissecada do hemisfério cerebral congelado e submetida à técnica de isolamento de RNA seguindo as instruções do fabricante do Mini kit RNeasy (\#74104; Qiagen).

O tecido foi fragmentado e homogeneizado em $350 \mu \mathrm{L}$ do tampão RLT com $\beta$ mercaptoethanol. Depois disso, o lisado foi centrifugado por 3 minutos na velocidade máxima e $350 \mu \mathrm{L}$ do sobrenadante foi transferrido para $350 \mu \mathrm{L}$ de etanol $70 \%$, sendo em seguida homogeneizado com a pipeta. A solução foi transferida para a coluna de extração de RNA com tubo coletor de $2 \mathrm{~mL}$ e centrifugada por 15 segundos na velocidade máxima. O eluente foi discartado em todos os passos até a substituição do tubo coletor de $2 \mathrm{~mL}$ pelo de $1,5 \mathrm{~mL}$. O volume de $700 \mu \mathrm{L}$ do tampão RW1 foi adicionado à coluna e em seguida centrifugado por 15 segundos na velocidade máxima. Depois disso, $500 \mu \mathrm{L}$ do tampão RPE foi adicionado à coluna e centrifugado por 15 segundos na velocidade máxima. O mesmo volume de tampão RPE foi adicionado novamente à coluna e centrifugado por 2 minutos na velocidade máxima. Em seguida, a coluna foi substituída por um novo tubo coletor de $2 \mathrm{~mL} e$ centrifugada por 1 minuto na velocidade máxima com o objetivo de secar a membrana. Para eluir o RNA, o tubo coletor de $2 \mathrm{~mL}$ foi substituído por um novo de $1,5 \mathrm{~mL}$ e $30 \mu \mathrm{L}$ de água livre de RNAse foi adicionado à coluna, seguida por uma centrifugação de 1 minuto na velocidade máxima. Após esse procedimento, o volume eluído foi submetido ao mesmo passo descrito anteriormente com o intuito de aumentar a concentração de RNA.

A concentração de RNA e as razões 260/240 e 260/230 foram medidas utilizando o Nanodrop. As amostras que tiveram valores de 260/230 menores que 1.0 foram quantificadas por qubit.

Depois de realizada a quantificação, o RNA foi hibridizado e multiplexado com sondas do painel Neuropatológico do NanoString, seguindo as instruções do fabricante. Para verificar a variabilidade, os genes-alvos foram normalizados com os house-keeping, que foram: Supt7I, Aars, Lars, Ccdc127, Mto1, Csnk2a2, Tada2b, Asb7, Fam104a, and Cnot10. O background foi calculado como o valor médio da hibridização negativa das sondas controles. 


\subsection{Análise dos dados}

As imagens inteiras da SN e do CPu foram obtidas pelo slide scanner Axion Scan Z.1 (Zeiss, Germany), com o qual foi possível ter uma visão geral dos tratamentos realizados. Além disso, as imagens dos neurônios dopaminérgicos foram capturadas com objetiva de 20x utilizando microscópio confocal e as células foram quantificadas pelo software Bitplane Imaris (Andor Technology, Switzerland).

As quantificações e as análises morfológicas da microglia foram realizadas como descrito por Elmore e colaboradores (143). Além disso, as células foram modeladas usando o software Bitplane Imaris para a análise da área do corpo celular. Com relação aos marcadores de astrócitos, as quantificações de GFAP e $S 100 \beta$ foram feitas no software ImageJ (National Institute of Health, USA) utilizando a ferramenta de ajuste do limiar e a medida da porcentagem de área.

Os dados do Nanostring foram analisados pelo software nSolver ${ }^{\mathrm{TM}}$ Analysis Software (Institute for Systems Biology, Seatle, USA) usando o painel neuropatólogico para camundongos.

\subsection{Análise Estatística}

Os resultados foram plotados como média \pm erro padrão da média (SEM). A normalidade e a homogeneidade de variância foram analisadas pelo teste de Shapiro-Wilk e pelo teste de Levene, respectivamente. Os testes comportamentais foram analisados pelo teste ANOVA de três vias para medidas repetidas com pósteste de Bonferroni ou Tukey, enquanto que para as quantificações celulares foi usado o teste ANOVA de duas vias com pós-teste de Bonferroni. Quando os dados não apresentaram homogeneidade de variância, foram realizadas transformações dos valores até que estes ficassem homogêneos. Quando os valores não ficaram homogêneos depois das transformações, os dados foram analisados por Kruskal Wallis com pós-teste de Mann-Whitney. Todas as análises foram realizadas nos softwares SPSS ou SAS. Diferenças entre os grupos experimentais foram consideradas significantes quando $p<0,05$.

Os resultados do NanoString foram analisados pelo software Advanced Analysis in the nSolver, que utiliza o $\mathrm{R}$ como programa estatístico. A diferença nas expressões com relação às covariáveis especificadas foi calculada usando um modelo misto binominal negativo para sondas de baixa expressão ou um modelo binominal negativo simplificado para sondas de alta expressão. 


\section{RESULTADOS}

\subsection{Performance no teste do poste}

$\mathrm{Na}$ figura 21, o gráfico apresenta os resultados do desempenho no teste do poste entre os quatro grupos, considerando o período de tempo em que os camundongos foram submetidos às injeções de 6-OHDA ou veículo. Os resultados mostram que a disfunção motora foi observada nos grupos com DP, submetidos ou não ao tratamento com PLX5622 depois de 14 dias da cirurgia, quando comparados aos seus controles correspondentes. Comparações entre os grupos WT e DP indicam um declínio significativo no grupo DP com $p=4 \times 10^{-6}(F(3,29)=32,431)$, sendo que seu efeito foi independente da depleção microglial ( $p=4,39 \times 10^{-10}$; $F(3,29)=84,337)$. Entretanto, no dia 7 não foi observada diferença entre os grupos analisados.

A interação entre os três fatores considerados (tratamento com PLX5622, injeções de 6-OHDA e dias após a cirurgia) usando o teste ANOVA de três vias foi significativa ( $p=0,026 ; F(3,29)=4,338$ ), indicando que o grupo DP com depleção microglial apresentou um aumento no comprometimento motor para escalar o poste no dia 14 quando comparado ao DP controle ( $p=0,028 ; F(3,29)=5,348)$. Esse resultado sugere que a depleção microglial pode acelerar 0 processo neurodegenerativo causado pela injeção de 6-OHDA.

Figura 21. Depleção microglial aumenta a disfunção motora em camundongos submetidos à 6-OHDA no teste do poste.

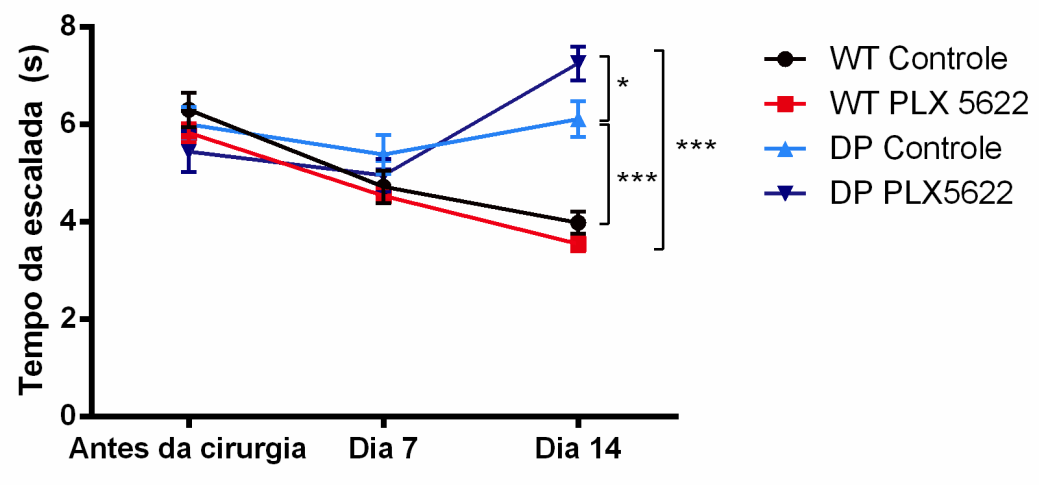

O gráfico mostra o tempo que cada grupo levou para escalar o poste. Os grupos com DP levaram mais tempo para realizar a escalada após 14 dias da cirurgia quando comparados 
aos grupos WT submetidos ao mesmo tratamento, devido aos déficits motores causados pela 6-OHDA. O grupo DP submetido ao tratamento com PLX5622 mostrou uma disfunção motora significativa quando comparado com o grupo DP controle $(p=0,028 ; F=5,348)$, indicando que a redução da microglia pode acelerar o processo neurodegenerativo causado pela toxina. ${ }^{*} \mathrm{p}<0,05,{ }^{* *} \mathrm{p}<0,001, \mathrm{n}=6-10$.

\subsection{Análise do Campo Aberto}

Os resultados do teste do campo aberto mostraram que o tratamento com PLX5622 e a indução por 6-OHDA não alteram os parâmetros analisados. Como pode ser observado no painel A da figura 22, a distância percorrida foi significativamente reduzida em todos os quatro grupos nos dois dias analisados quando comparado com o mesmo grupo no período antes da cirurgia. O grupo WT PLX5622 apresentou uma redução significativa no período que antecede a cirurgia quando comparado com o grupo controle $(p=0,0238)$, indicando que os camundongos selecionados para esse grupo já apresentavam pouca atividade exploratória. Este resultado também foi observado quando analisado a velocidade média com $\mathrm{p}=0,0226$ (painel $\mathrm{B}$ ).

No sétimo dia, foi observado que todos os grupos tiveram uma redução significativa tanto na distância percorrida quanto na velocidade média, quando comparados com o mesmo grupo no período anterior a cirurgia. O grupo WT PLX5622 mostrou uma redução significativa na distância total quando comparado com o grupo WT controle $(p=0,0019)$ e quando comparado com DP PLX5622 $(p=0,0196)$. Essa redução também foi observada na velocidade média com $p=0,0019$ quando comparado com o WT controle e $p=0,0182$ quando comparado com o DP PLX5622, indicando que essa redução não é decorrente do tratamento com PLX5622 e sim da lenta atividade exploratória desses animais como citado anteriormente.

No décimo quarto dia, todos os grupos apresentaram redução significativa nos dois parâmetros, distância percorrida e velocidade média, quando comparados com o mesmo grupo no período antes da cirurgia. Não foram observadas diferenças entre os grupos tratados com PLX5622 e com a dieta controle, bem como entre aqueles induzidos à DP e os que não foram induzidos. Assim, os resultados mostram que a atividade exploratória não foi alterada com a indução pela toxina e/ou com a eliminação da microglia. 
Outros dois parâmetros analisados foram: o tempo despendido na zona central e no perímetro. Como pode ser notado no painel $\mathrm{C}$ da figura 22 , o grupo DP PLX5622 apresentou redução significativa no tempo que permaneceu no perímetro no sétimo dia, quando comparado com WT PLX5622 ( $p=0,0404)$ e quando comparado com o mesmo grupo antes da cirurgia $(p=0,0207)$. Com relação à zona central (painel D), o grupo DP com depleção microglial foi o único grupo que permaneceu mais tempo nessa região no dia 7 quando comparado com WT PLX5622 $(p=0,040)$ e quando comparado com a sua performance antes da cirurgia $(p=0,0207)$.

Figura 22. Distância percorrida e velocidade média do teste de campo aberto não foram influenciados pela 6-OHDA e pelo tratamento com PLX5622.

A
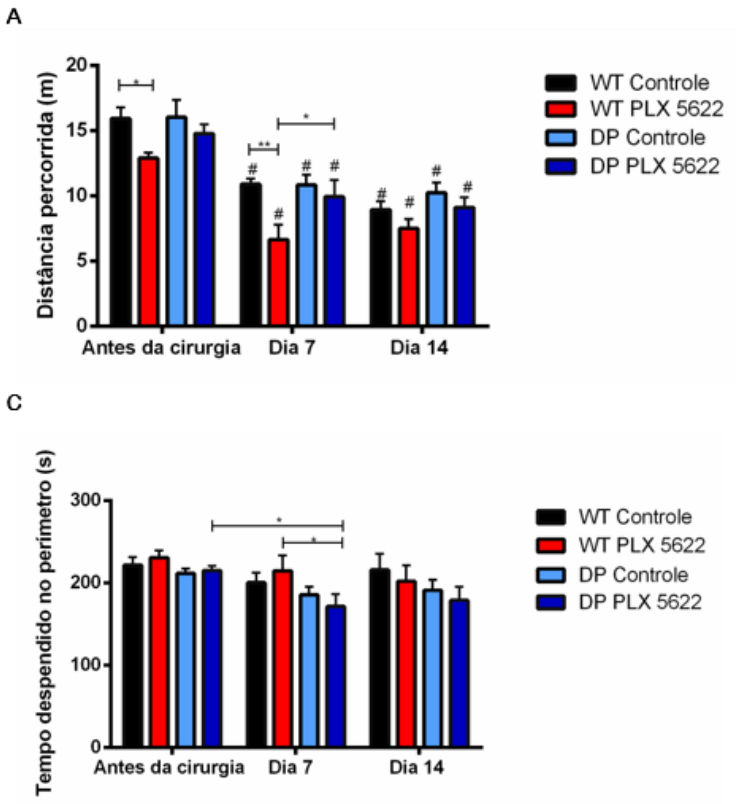

B

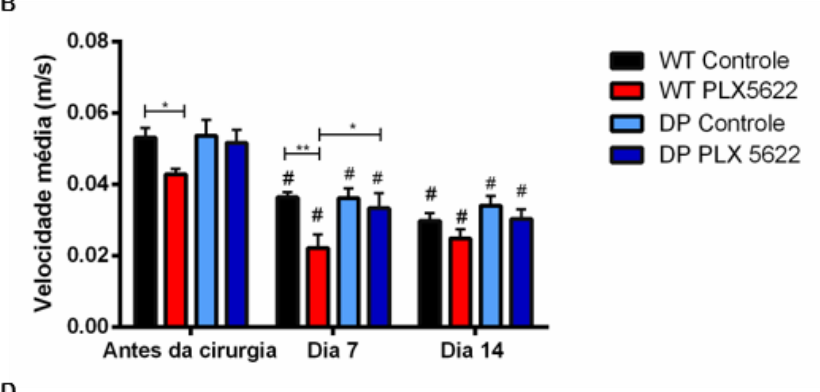

D

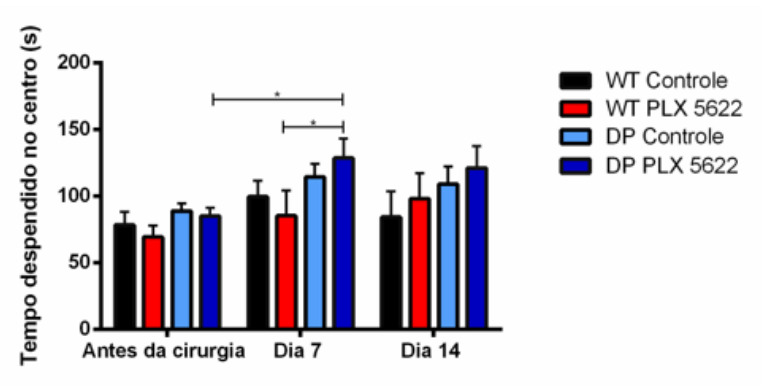

A. O gráfico mostra a distância percorrida em metros nos quatro grupos nos três períodos de tempo (antes da cirurgia, no sétimo dia e no décimo quarto dia depois da cirurgia). Os resultados mostram a redução significativa apresentada nos quatro grupos no dia 7 e 14 quando comparados aos seus valores antes da cirurgia, indicando que a dieta e/ou a toxina não influenciaram nesse parâmetro. B. Gráfico mostrando a velocidade média dos quatro grupos durante a execução do teste. Como observado na distância percorrida, as diferenças observadas não foram induzidas pela dieta e/ou toxina. C. Gráfico mostrando o tempo despendido no perímetro para cada grupo, observando-se a redução significativa no tempo do grupo DP PLX5622 quando comparado ao WT PLX5622 no sétimo dia ( $p=0,0404)$. D. O 
gráfico mostra o tempo gasto na zona central, indicando que o grupo DP PLX5622 permaneceu mais tempo nessa região quando comparado com WT PLX5622.

\subsection{Performance no Rota rod}

O Rota rod acelerado foi outro teste comportamental usado para avaliar os efeitos de 6-OHDA na coordenação motora e no equilíbrio. A figura 23 mostrou que o grupo DP controle apresentou uma redução no tempo médio despendido na roda nas cinco tentativas realizadas no dia 7 quando comparado com o WT controle $(p=0,0035)$. Entretanto, essa redução não foi observada no dia 14 .

Figura 23. A indução pela 6-OHDA reduziu o tempo médio de permanência no teste rota rod somente no sétimo dia.

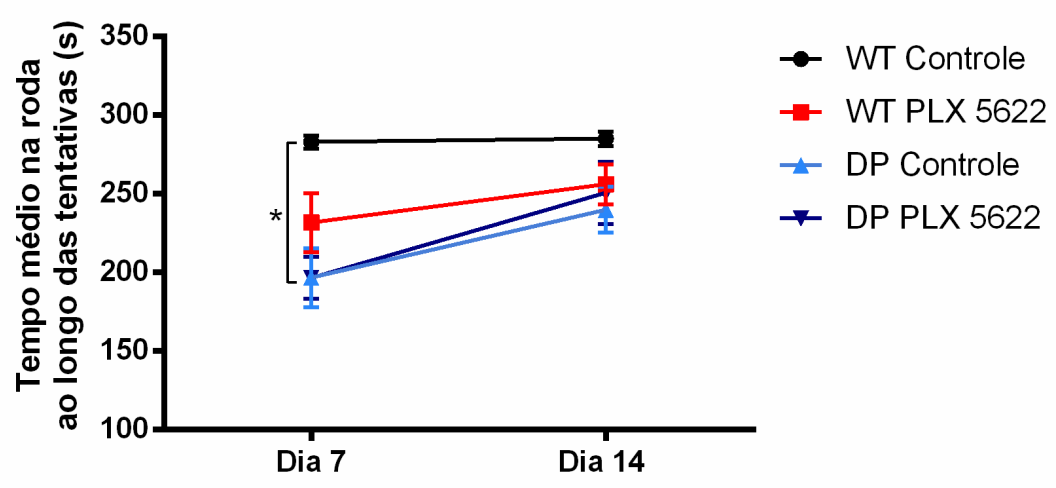

O gráfico mostra a média \pm SEM do tempo de permanência na roda durante as 5 tentativas tanto no sétimo quanto no décimo quarto dia após a cirurgia. O grupo DP controle apresentou redução significativa no tempo médio quando comparado ao controle somente no sétimo dia. * $\mathrm{p}<0,05$ (pós teste de Turkey-Kramer), $\mathrm{n}=6-10$ camundongos.

As razões pelas quais os grupos interromperam o teste tanto no sétimo (painel A) quanto no décimo quarto dia (painel B) estão ilustradas na figura 24. Como pode ser observado nos gráficos, o grupo DP controle foi o grupo que mais caiu da roda nos dois dias analisados, podendo ser um indicativo do efeito da droga na habilidade motora. Por outro lado, os grupos WT controle e WT PLX5622 foram os grupos que mais permaneceram na roda nos dois dias. 
Figura 24. Análise das razões de finalização no teste do rota rod
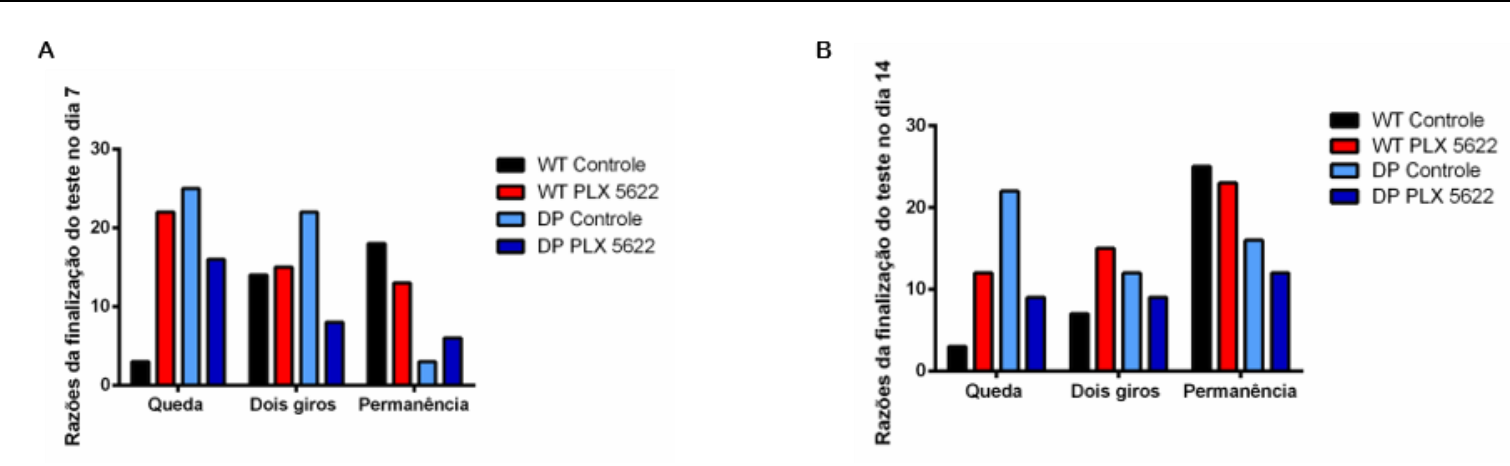

No painel $\mathbf{A}$, o gráfico mostra as razões pelas quais cada camundongo parou o teste no sétimo dia, enquanto que o painel $\mathbf{B}$ ilustra as razões do décimo quarto dia. As razões descritas foram: queda da roda e realizar duas voltas consecutivas. $n=6-10$ camundongos.

\subsection{Quantificação dos neurônios dopaminérgicos na SNpc}

Para avaliar os efeitos da 6-OHDA, os neurônios dopaminérgicos foram quantificados pela marcação do anticorpo anti-tirosina hidroxilase na SNpc. A redução da expressão de TH foi de $47,06 \%$ no grupo DP tratado com a dieta controle $(90,66 \pm 13,58)$ quando comparado com o WT controle $(171,28 \pm 32,62)$, como pode ser observado comparando-se as imagens dos painéis $E$ e $G$ da figura 25 ( $p=0,049 ; F(3,21)=4,335)$. O mesmo resultado foi observado entre os grupos tratados com PLX5622, sendo que a perda de neurônios dopaminérgicos no grupo DP pode ser observada no painel $\mathrm{H}$ quando comparado com o controle, painel $\mathrm{F}$ $\left(p=2,04 \times 10^{-4} ; F(3,21)=20,513\right)$. As figuras A-D mostram o corte total do cérebro com a marcação do anticorpo anti-TH em verde e anti-lba-1 em vermelho, em que pode ser observada a redução dos dois marcadores nos grupos tratados com PLX5622 (imagens B e D).

Além disso, a redução significativa de $47,05 \%$ na expressão de $\mathrm{TH}$ foi observada no grupo DP com depleção microglial $(48 \pm 9,19)$ quando comparado com DP sem alteração no número de células microgliais $(90,66 \pm 13,58 ; p=0,029$; $F(3,21)=5,508)$, indicando que a diminuição no número de microglias torna o neurônio mais susceptível aos efeitos da toxina e, consequentemente, à morte celular. 
Figura 25. A expressão de TH está reduzida significativamente na SNpc dos camundongos submetidos às injeções de 6-OHDA e à depleção microglial.
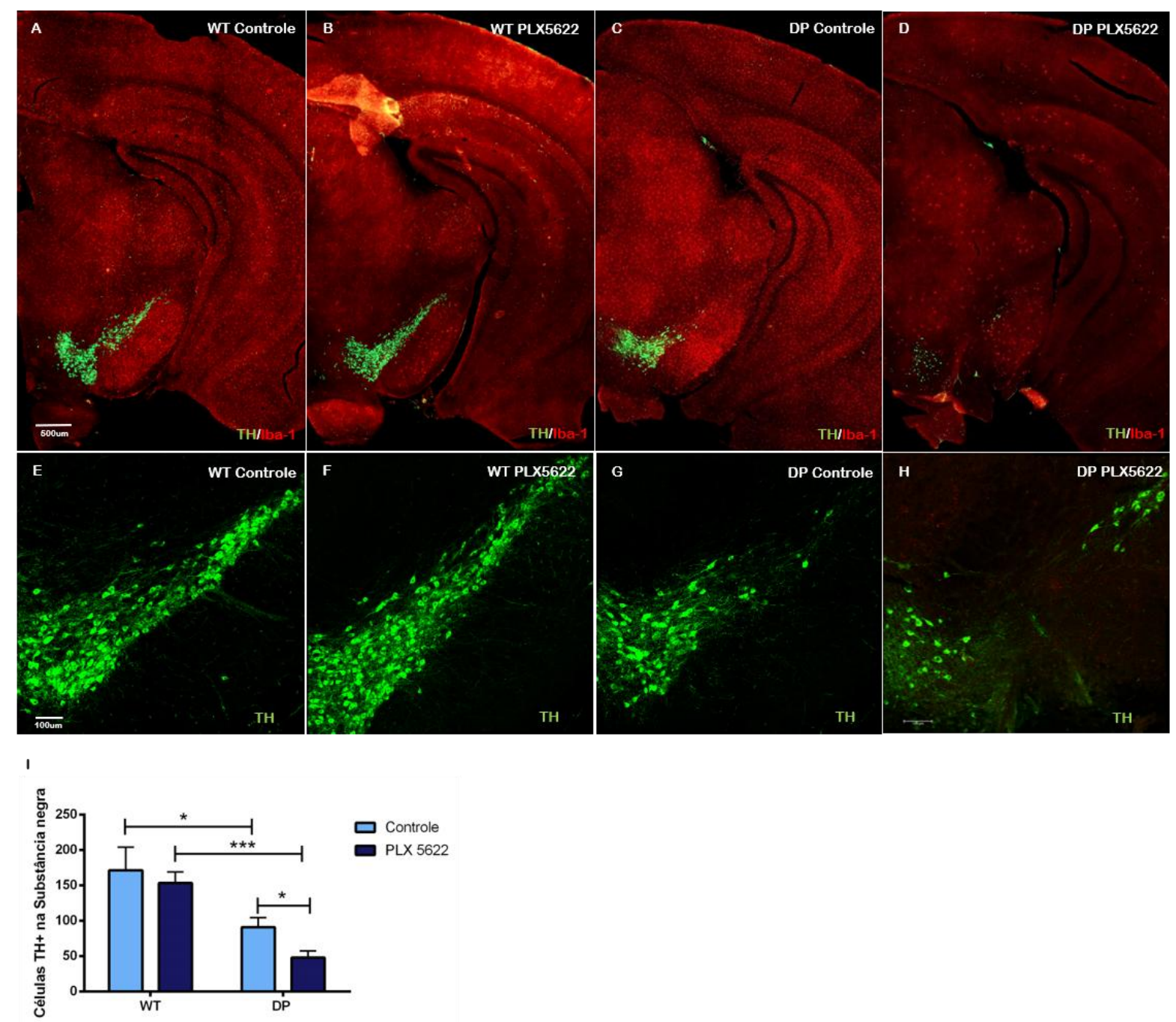

A-D: Imagens imunofluorescentes da substância negra, mostrando células TH positivas marcadas em verde e células lba-1 positivas marcadas em vermelho nos quatro grupos. A. Imagens da SN de camundongos submetidos à injeções de veículo no CPu e tratados com dieta controle. B: Grupo WT tratados com PLX5622. C: Grupo submetido à injeções de 6OHDA e tratados com dieta controle. D: Grupo submetido às injeções de 6-OHDA e tratados com PLX5622. E-H: Imagens representativas de células TH positivas na SNpc mostrando a redução da sua expressão nos dois grupos DP. I: O gráfico mostra a redução significativa na expressão de TH nos grupos DP quando comparados aos seus respectivos controles, bem como, a significante perda de neurônios dopaminérgicos no grupo DP com eliminação microglial quando comparado ao grupo DP controle. * $\mathrm{p}<0,05,{ }^{* * *} \mathrm{p}<0,001, \mathrm{n}=6-10$.

\subsection{Quantificação das células microgliais e do marcador CD68 na SNpc}

A eliminação das células microgliais foi avaliada pela quantificação das células Iba-1 positivas na SNpc (figura 26) e no CPu (figura 28). O teste estatístico ANOVA de duas vias mostrou que o número de células microgliais na SNpc apresentou uma 
significativa interação com a indução por 6-OHDA e com o tratamento com PLX5622 $(\mathrm{p}=0,020 ; \mathrm{F}(3,23)=6,286)$.

Como está ilustrado nos painéis $A-D$ da figura 26, o número de células microgliais foi significativamente menor nos grupos WT e DP tratados com PLX5622, evidenciando assim, o efeito do inibidor de CSF1R. A diferença significativa entre os grupos que receberam as injeções de veículo no CPu pode ser visualizada pela comparação entre as imagens $\mathrm{A}$ e $\mathrm{B}$, sendo que o grupo submetido à dieta controle teve uma média de $867,00 \pm 43,72$ de células positivas para lba-1 e o que recebeu PLX5622, uma média de 79,5 $\pm 22,64\left(p=4,80 \times 10^{-9} ; F(3,23)=82,002\right)$. A eliminação microglial no grupo WT foi de $90,83 \%$, enquanto que no grupo DP foi de $82,68 \%$. Nos grupos DP, a redução significativa pode ser visualizada pela comparação das imagens $C$ e $D$, sendo que o grupo submetido à dieta controle apresentou uma média de 1300,33 $\pm 59,85$ de células $\mathrm{lba}-1^{+}$, enquanto que a média daquele submetido à PLX5622 foi de 225,16 $\pm 71,70\left(p=5,6423 \times 10^{-13} ; F(3,23)=206,353\right)$. Além disso, foi observado um aumento no número de células microgliais no DP controle $(1300,33 \pm 59,85)$ quando comparado ao WT controle $(867,00 \pm 43,72$; $\left.\mathrm{p}=3,8 \times 10^{-5} ; \mathrm{F}(3,23)=25,785\right)$, o que já foi evidenciado em outro estudo desse modelo (104).

Com relação à área das células marcadas com lba-1, os grupos com depleção microglial apresentaram um aumento de cerca de 68\% quando comparados aos controles correspondentes (gráfico $O$ da figura 23). WT PLX5622 mostrou um aumento significativo na área celular $(168,48 \pm 6,05)$ quando comparado com 0 grupo controle $(100,55 \pm 1,65$; Mann-Whitney; $p=0,010, U=24,000)$, e com DP PLX5622 ( $p=0,03 ; U=3,000)$. Com relação aos grupos DP, o grupo submetido a PLX5622 (143,29 \pm 5,12) apresentou um aumento de 68,29\% quando comparado com o DP controle $(85,14 \pm 1,20 ; p=0,001, U=45,000)$, sendo que este mostrou a menor area de células $\mathrm{Iba}-1^{+}$entre os quatros grupos $(\mathrm{p}=0,003$ relacionado a WT controle).

Além disso, o anticorpo anti-CD68 marca uma glicoproteína transmembrana endossomal da microglia que é considerada um indicador de atividade fagocítica (144). O gráfico P mostra que o grupo DP controle teve um aumento significativo da intensidade de CD68 quando comparado com WT controle $(p=0,049$; $F(3,22)=4,344)$ e quando comparado com DP PLX5622 ( $p=2,63$ x 10 $F(3,22)=18,829)$. Por outro lado, o grupo WT PLX5622 apresentou uma redução da 
intensidade quando comparado com 0 grupo controle $\left(p=4,98 \times 10^{-4}\right.$; $F(3,22)=16,635)$ e quando comparado com DP PLX5622 ( $p=0,015 ; F(3,22)=7,016)$. Com isso, o processo neurodegenerativo causado pela 6-OHDA na SNpc pode ter influenciado o aumento da atividade fagocítica microglial, enquanto que a eliminação microglial atenuou essa atividade, como pode ser evidenciado pela co-localização dos dois marcadores na figura 27. 
Figura 26. O número de células microgliais e a intensidade do marcador CD68 estão reduzidos nos grupos WT e DP tratados com PLX5622 na SNpc.
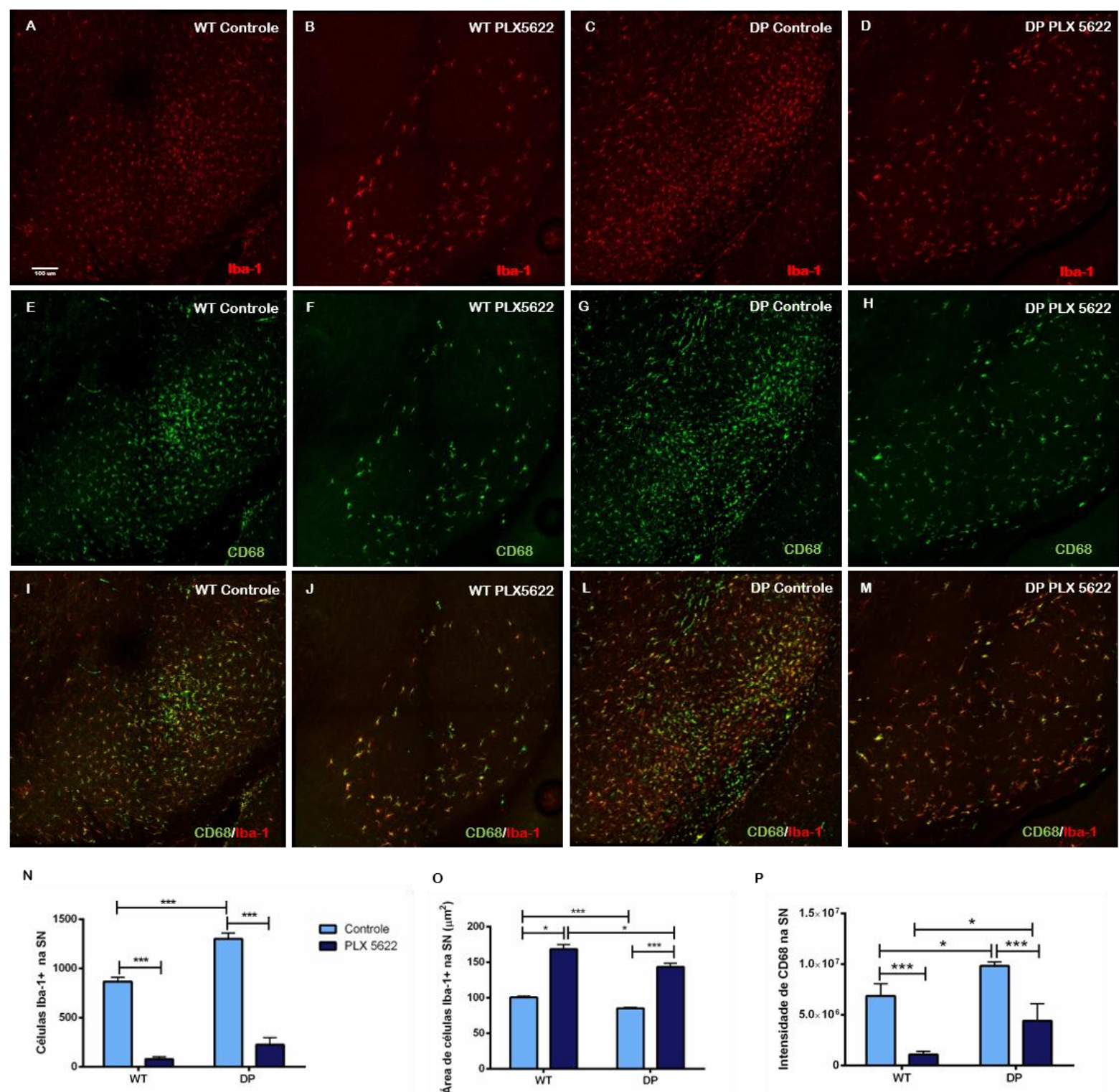

A-D. Imagens imunofluorescentes na SNpc mostrando células $\mathrm{Iba}-1^{+}$em vermelho. $\mathrm{O}$ número de células lba- $1^{+}$foi significativamente reduzido em WT PLX5622 (painel B) e em DP PLX5622 (painel D), enquanto que mostrou-se significantemente elevado no DP controle (painel C). E-H. Imagens representativas de células positivas para CD68 em quatro diferentes grupos identificados em cada painel. I-M. Imagens imunofluorescentes mostrando a combinação dos dois marcadores nos grupos especificados. $\mathbf{N}$. O gráfico mostra a redução significativa de células lba-1+ nos dois grupos tratados com o inibidor de CSF1R e o aumento significativo do número de células microgliais no grupo DP controle quando comparado ao WT controle. $\mathbf{0}$. O gráfico mostra o aumento da área das células $\mathrm{Iba}-1+$ nos grupos tratados com PLX5622 e a redução no grupo DP controle quando comparado ao WT controle. P. Gráfico mostra a redução significativa na intensidade de CD68 em ambos os grupos tratados com PLX5622. * $\mathrm{p}<0,05,{ }^{* * *} \mathrm{p}<0,001$ 
Os resultados da co-localização mostraram um aumento significativo nesse parâmetro no grupo DP controle quando comparado com o WT, como pode ser observado comparando-se os painéis I e $L$ da figura 27 ( $p=0,027 ; F(3,23)=5,549$ ). Por outro lado, o tratamento com PLX5622 reduziu significativamente a colocalização no grupo DP quando comparado ao grupo submetido à dieta controle $(p=0,006 ; F(3,23)=8,986)$. A diferença entre os tratamentos nos indivíduos WT não foi significante (Imagens I e J; $p=0,073 ; F(3,23)=3,535$ ). Além disso, o gráfico $O$ apresenta o coeficiente de Pearson entre os marcadores lba-1 e CD68 nos quatro grupos. Essa relação mostrou-se significativamente fraca somente no WT PLX5622 quando comparado ao controle $(p=0,004 ; F(3,22)=10,095)$ e quando comparado ao DP PLX5622 $\left(p=6,5 \times 10^{-5} ; F(3,22)=24,150\right)$. 
Figura 27. Tratamento com PLX5622 reduz significativamente a co-localização entre os marcadores Iba-1 e CD68 na SNpc do grupo DP.
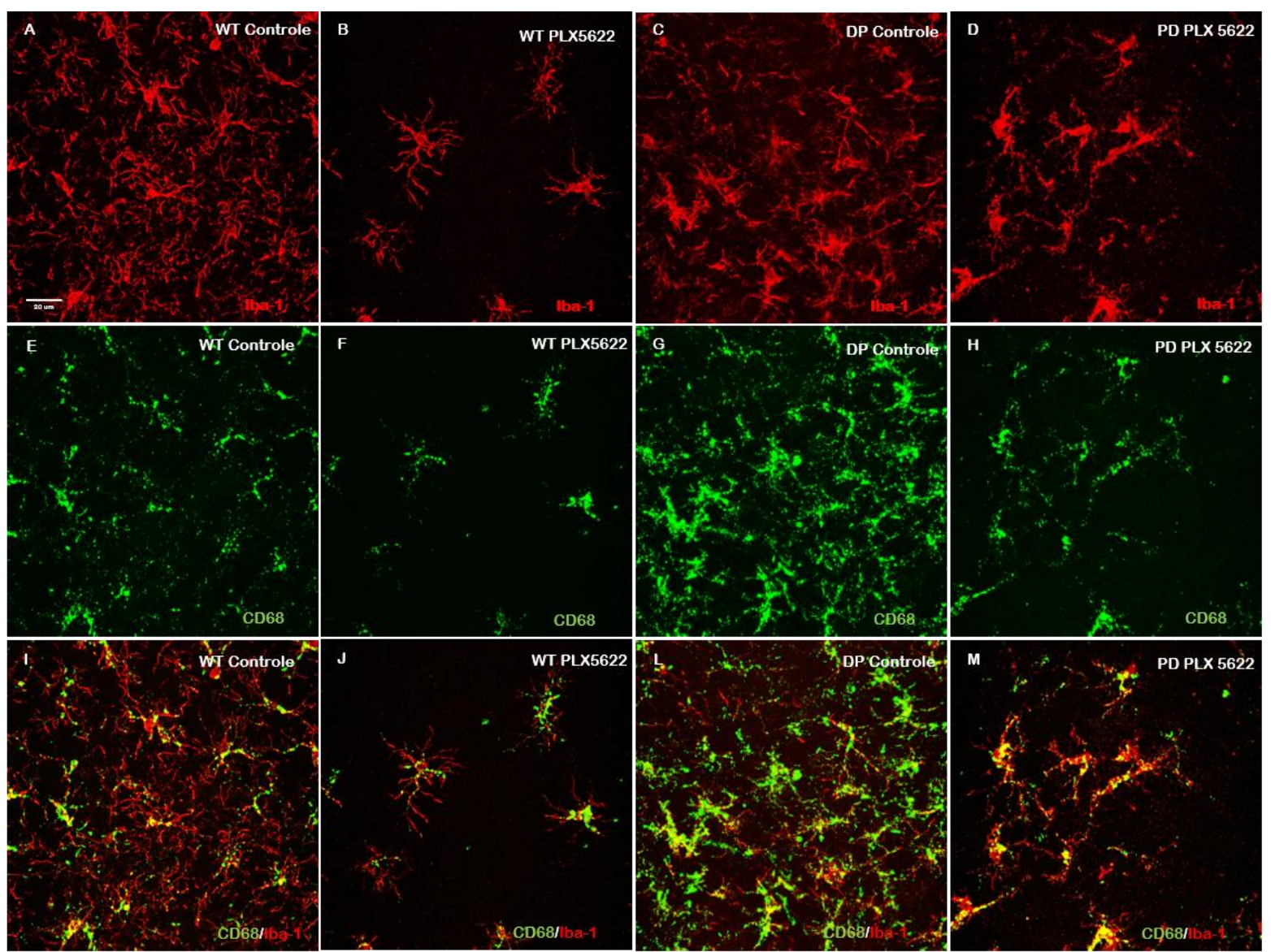

$\mathrm{N}$

o
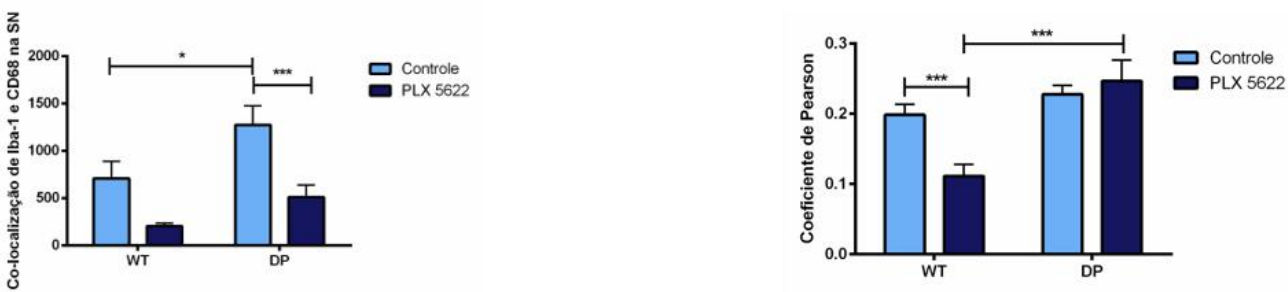

A-D. Imagens imunofluorescentes capturadas em objetiva de $63 x$, mostrando células Iba-1+ na SNpc dos grupos especificados nos painéis. E-H. Imagens de células CD68+ na SNpc dos quatro grupos. I-M. Imagens representativas mostrando a co-localização entre os dois marcadores e seu evidente aumento no grupo DP controle (imagem L). N. O gráfico mostra que a indução de DP leva a um aumento da atividade fagocítica nas células microgliais quando comparado ao WT, bem como, a redução efetiva desse marcador nos grupos DP com depleção microglial. 0 . O gráfico mostra o coeficiente de Pearson da co-localização, que está reduzida no grupo WT PLX5622. ${ }^{*} p<0,05$, ${ }^{* * *} p<0,001, n=6-10$. 


\subsection{Quantificação das células microgliais e de CD68 no CPu}

Como observado na SNpc, os grupos que receberam o inibidor de CSF1R apresentaram número reduzido de células $\mathrm{Iba}^{-1^{+}}$. O teste ANOVA de duas vias mostrou que não houve interação entre a indução de DP (6-OHDA ou veículo) e o tratamento (PLX5622 ou controle) $(p=0,318 ; F(3,28)=1,033)$, entretanto, os dois fatores tiveram efeitos independentes significantes nessa quantificação (para a indução $p=0,007$ and $F(3,28)=8,474$; para 0 tratamento, $p=1,73 \times 10^{-10}$, $F(3,28)=94,748)$.

A redução significativa no número de células microgliais foi cerca de 6 vezes no grupo WT PLX5622 $(149,10 \pm 44,28)$ quando comparado com o controle $(917,85 \pm$ 84,$\left.51 ; p=6,59 \times 10^{-7} ; F(3,28)=40,727\right)$, que estão representados nas imagens $B$ e $A$ da figura 28 , respectivamente. Nos grupos $D P$, aqueles submetidos ao tratamento com PLX5622 $(316,16 \pm 114,07)$ tiveram 4 vezes menos microglia quando comparado ao controle (1264.22 \pm 105.81; $p=5.16 \times 10-8 ; \quad F(3,28)=54.154)$, como pode ser observado comparando-se as imagens C e D. Assim como na SNpc, o grupo DP controle apresentou aumento significativo no número de células quando comparado ao WT controle $(p=0,009 ; \quad F(3,28)=7,906)$, evidenciando $\circ$ processo neuroinflamatório causado pelos efeitos da 6-OHDA.

Apesar da redução significativa no número das células $\mathrm{lba-1^{+ }}$ nos grupos tratados com PLX5622, essas células apresentaram um aumento na área celular em relação aos controles. Como pode ser notado no gráfico $O$, as células do WT PLX5622 $\left(155,11 \mu \mathrm{m}^{2} \pm 7,85\right)$ tiveram um aumento de cerca de 1,49 vezes em relação ao controle $\left(103,46 \mu \mathrm{m}^{2} \pm 1,18\right.$; Mann-Whitney; $\left.p=3,10 \times 10^{-4} ; U=56,000\right)$. $O$ mesmo resultado foi observado nos grupos $\mathrm{DP}$, nos quais as células em presença do inibidor CSF1R $\left(117,22 \mu \mathrm{m}^{2} \pm 5,57\right)$ apresentaram um aumento de 1,2 vezes em relação ao controle $\left(97,42 \mu \mathrm{m}^{2} \pm 4,08 ; p=0,034 ; U=32,000\right)$. Também foi observado que a área celular do DP PLX5622 é significativamente menor em relação ao WT PLX5622 ( $p=0,008 ; U=1,000)$.

Com relação à intensidade da marcação de CD68, o tratamento com PLX5622 foi o único fator que influenciou essa medida $(p=0,006 ; F(3,28)=9,237)$ como pode ser notado pela redução significativa nos grupos com eliminação microglial (gráfico $P$ da figura 28). As diferenças entre os grupos WT estão apresentadas nas imagens $E$ e $F$, sendo $p=0,050 \quad(F(3,28)=4,274)$, enquanto que entre os $D P$, podem ser visualizadas nas imagens $H$ e $G$ com $p=0,035(F(3,28)=4,975)$. Essa redução pode 
ser devido à dimunição do número de células microgliais ou da atenuação do processo neuroinflamatório, no qual o primeiro pode ser avaliado por meio da colocalização.

Figura 28. No $\mathrm{CPu}$, as células lba-1+ e CD68+ estão reduzidas nos grupos submetidos à depleção microglial.

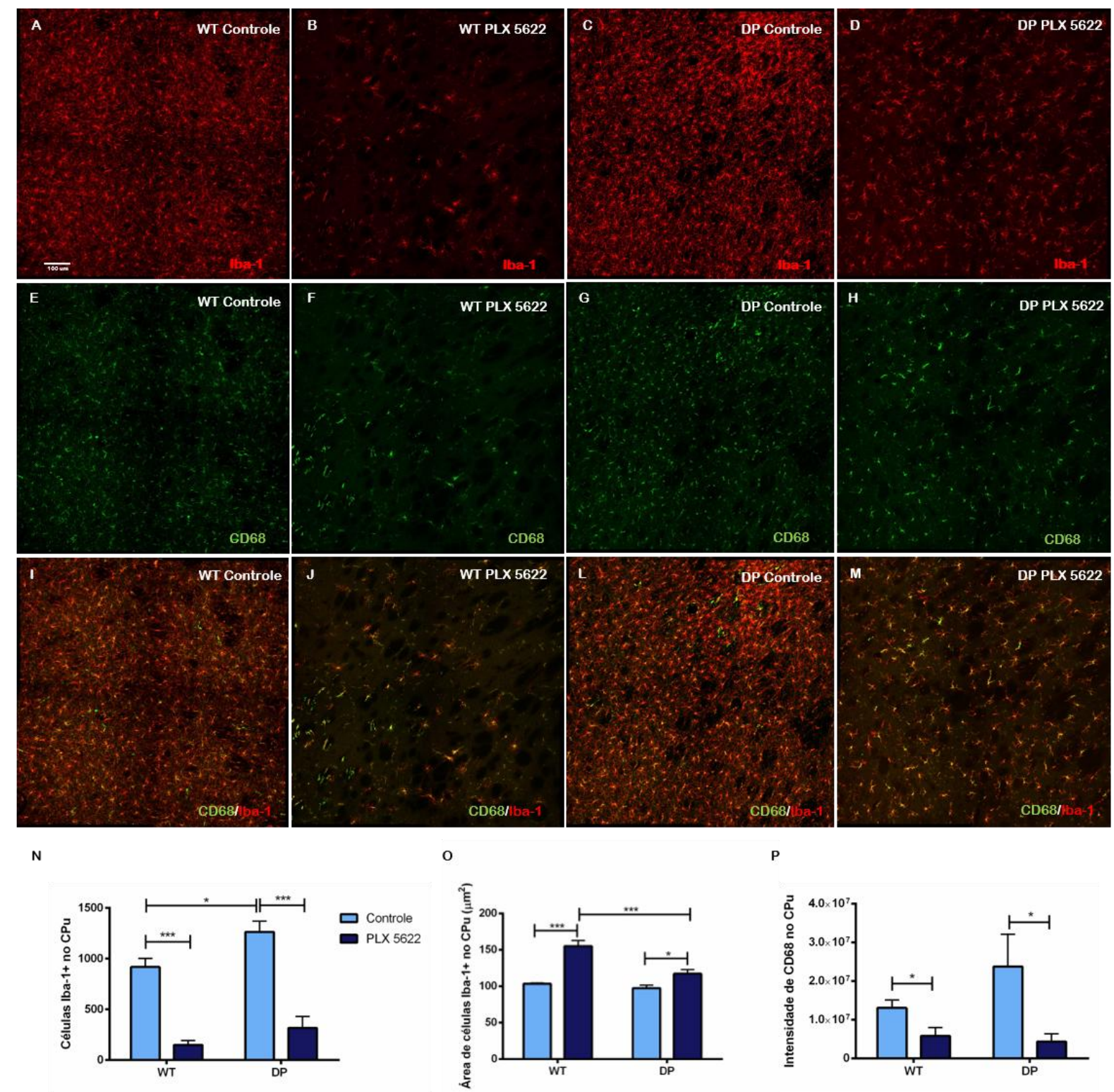

A-D. Imagens imunofluorescentes do CPu mostrando as células lba-1 ${ }^{+}$marcadas em vermelho. O número de células microgliais está significativamente reduzido nos grupos tratados com PLX5622 (WT no painel B e DP no painel D) e elevado no grupo DP controle (painel C). E-H. Imagens representativas da marcação de CD68 nos quatro grupos, mostrando a redução da intensidade naqueles submetidos à PLX5622. I-M. Imagens imunofluorescentes mostrando a combinação dos dois marcadores nos grupos especificados. N. O gráfico mostra a redução significativa de lba-1 em ambos os grupos 
tratados com o inibidor de CSF1R e o aumento do número dessas células no DP controle quando comparado com o WT. O. Os indivíduos submetidos à PLX5622 apresentaram um aumento na área das células marcadas com lba-1. P. O gráfico mostra a significativa redução na intensidade de CD68 nos indivíduos com depleção microglial. " $p<0,05$, ** $p<0,001, n=6-10$.

No $\mathrm{CPu}$, os resultados da co-localização entre CD68 e lba-1 estão apresentadas na figura 29 e são diferentes daqueles encontrados na SNpc. O teste ANOVA de duas vias mostrou que não houve interação entre a indução à DP e o tratamento com PLX5622 ( $p=0,401 ; F(3,27)=0,729)$, entretanto, o tratamento foi o fator significante nessa quantificação $\left(p=3 \times 10^{-6} ; F(3,27)=34,773\right)$. Os grupos WT e DP controles não tiveram diferenças significativas ( $p=0,673 ; F(3,27)=0,183$ ), enquanto que os indivíduos com depleção microglial tiveram uma redução significativa quando comparados com os controles. Nos WT, pode-se observar a redução da co-localização nos indivíduos submetidos à PLX5622 ( $\mathrm{p}=3 \times 10^{-5}$; $F(3,27)=25,074)$. O mesmo resultado também foi verificado no grupo DP PLX5622 $(p=0,002 ; F(3,27)=11,653)$.

Além disso, o gráfico $\bigcirc$ mostra 0 coeficiente de Pearson que está significantemente elevado nos grupos com eliminação microglial, sendo que $\mathrm{p}=1,6 \times 10^{-4}(\mathrm{~F}(3,23)=20,299)$ para os grupos WT e para os DP, $\mathrm{p}$ é igual a $4 \times 10^{-6}$ $(F(3,23)=36,056)$. 
Figura 29. No $\mathrm{CPu}$, a co-localização entre os marcadores lba-1 e CD68 está reduzida nos grupos tratados com PLX5622.

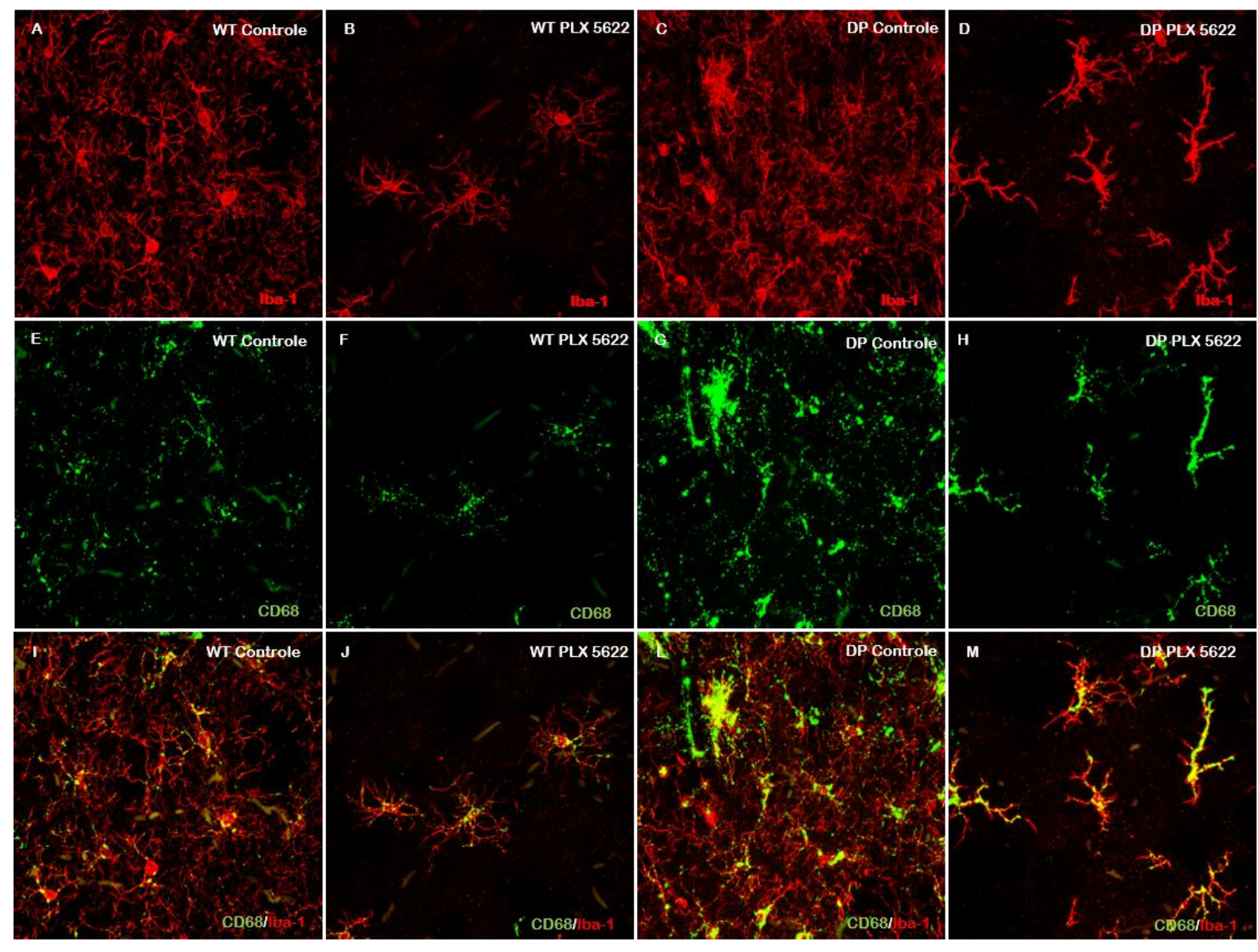

N

o
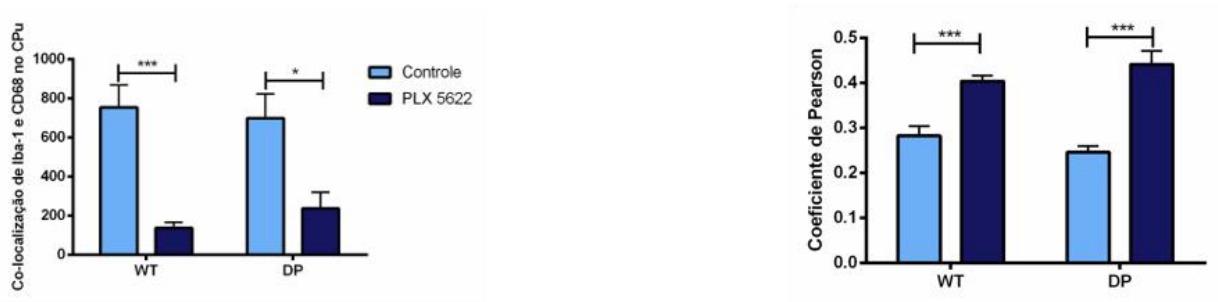

A-D. Imagens representativas com aumento de 100x de células Iba- $1^{+}$no CPu dos 4 grupos especificados nos painéis. E-H. Imagens mostrando células positivas para CD68. I-M. Imagens representativas mostrando que a co-localização dos dois marcadores estão reduzidas em WT PLX5622 (Imagem J) e em DP PLX5622 (Imagem M). N. O gráfico mostra a redução significativa nos grupos submetidos à eliminação microglial. $\mathbf{O}$. O gráfico mostra 0 coeficiente de Pearson da co-localização, que está significantemente elevada nos grupos tratados com PLX5622. ${ }^{*} p<0,05,{ }^{* * *} p<0,001, n=6-10$. 


\subsection{Expressão de TMEM119 e P2RY12 na substância negra}

Uma das maiores limitações no estudo da microglia consiste em distinguir esse tipo celular dos macrófagos, uma vez que possuem alguns marcadores em comum. Bennett e colaboradores (58) mostraram que TMEM119 é uma proteína transmembrana regulada durante o processo de desenvolvimento, sendo específica da superfície celular microglial, ou seja, não foi encontrada em macrófagos ou outras células neuronais. Nesse estudo, a SNpc foi imunomarcada com TMEM119 para confirmar que as células lba-1+ são microglias e não originárias de macrofágos infiltrantes. Como pode ser visualizado na figura 30, a maioria das células Iba-1+ foram marcadas por TMEM119 em todos os grupos analisados. Além disso, esse resultado sugere que o aumento de células lba-1+ no grupo DP controle são originárias de progenitores microgliais e não de macrófagos infiltrantes. 
Figura 30. Co-localização dos marcadores TMEM119 e lba-1 na SNpc nos quatro grupos.
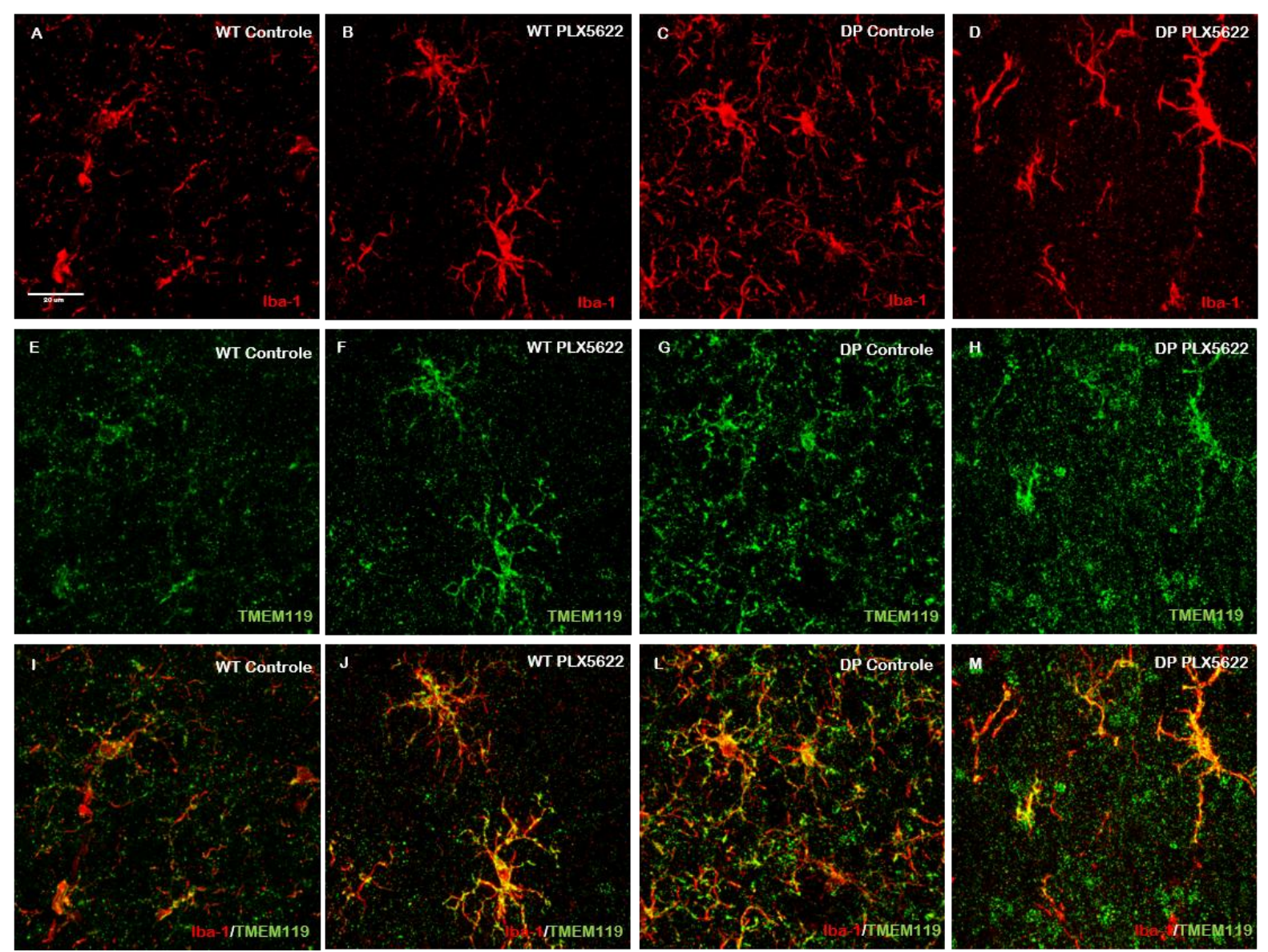

A-D. Imagens representativas obtidas a partir de aumento de 100x, mostrando as células marcadas com Iba-1 na SNpc dos quatro grupos. E-H. Imagens mostrando a marcação de TMEM119. I-M. Imagens representativas mostrando a co-localização de Iba-1 e TMEM119 e que as células lba-1+ são provenientes de progenitores microgliais e não de macrófagos infiltrantes.

Outra proteína que diferencia a microglia de outras células neuronais é a P2RY12, sendo também considerada um marcador que está expresso em microglias homeostáticas (145). A figura 31 ilustra a marcação desse marcador na SNpc dentro dos quatro grupos. Como esse anticorpo apresentou uma marcação de fundo intensa, a quantificação da co-localização não foi possível. Entretanto, pode-se observar nas imagens que a maioria das células lba-1+ foram marcadas com P2RY12, indicando que as células microgliais preservaram o perfil homeostático mesmo na presença do processo neurodegenerativo. 
Figura 31. Co-localização dos marcadores P2RY12 e lba-1 na SNpc dos quatro grupos analisados
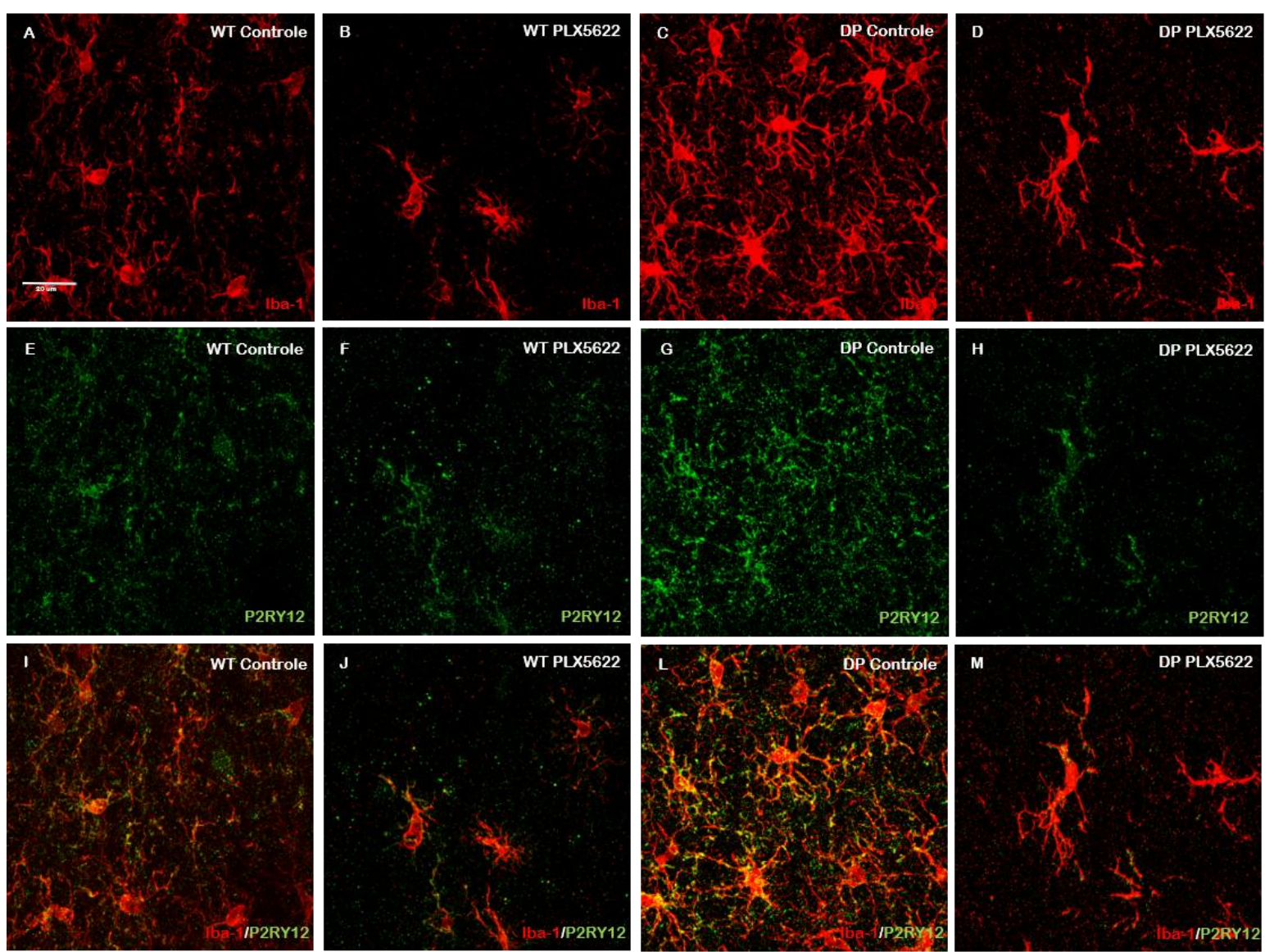

A-D. Imagens representativas, capturadas em aumento de 100x, mostrando células Iba-1+ na SNpc dos quatro grupos especificados. E-H. Imagens de células positivas para P2RY12 nos quatro grupos. I-M. Imagens imunofluorescentes mostrando a co-localização dos dois marcadores.

3.8. Expressão de marcadores de astrócitos

\subsubsection{Substância negra}

Com o objetivo de avaliar a resposta astrocítica na presença do inibidor CSF1R, foram analisadas a porcentagem de área marcada pelo anticorpo anti-GFAP na SNpc (figura 32). O único fator que interfere significativamente no número de astrócitos é o tipo de tratamento $(p=0,021 ; F(3,19)=6,386)$, sendo que os grupos com eliminação microglial (imagens B e D) tiveram uma redução significativa quando comparados com os controles (imagens A e C). A média da porcentagem de área marcada do grupo WT PLX5622 foi de 0,94 \pm 0,33, sendo inferior à apresentada pelo 
WT controle $(1,77 \pm 0,50)$. O mesmo resultado foi observado nos grupos DP, no qual o grupo submetido à eliminação microglial apresentou média de 0,87 $\pm 0,09$ e o controle, 1,96 $\pm 0,33$.

Além disso, foi quantificada a porcentagem de área marcada pelo anticorpo anti-S100ß. Esta protéina consiste em um importante fator neurotóxico liberado por células gliais ativadas e que pode desencadear a lesão e morte neuronal (146). Como pode ser visualizado na figura 32, nem o tipo de tratamento e nem a indução de DP foram fatores determinantes na expressão dessa proteína (Para o tratamento $p=0,47, F(3,21)=0,53$; Para a dieta, $p=0,23, F(3,21)=1,48)$. $O$ gráfico $O$ indica que não houve diferença entre os grupos, mostrando que a média da porcentagem de área marcada de cada grupo foram as seguintes: $5,15 \pm 1,25$ para WT controle; 6,41 $\pm 0,95$ para DP controle; 4,29 $\pm 1,12$ para WT PLX5622 e 4,62 $\pm 0,85$ para DP PLX5622. 
Figura 32. A porcentagem de área marcada com GFAP está reduzida nos grupos submetidos ao inibidor CSF1R na SNpc.
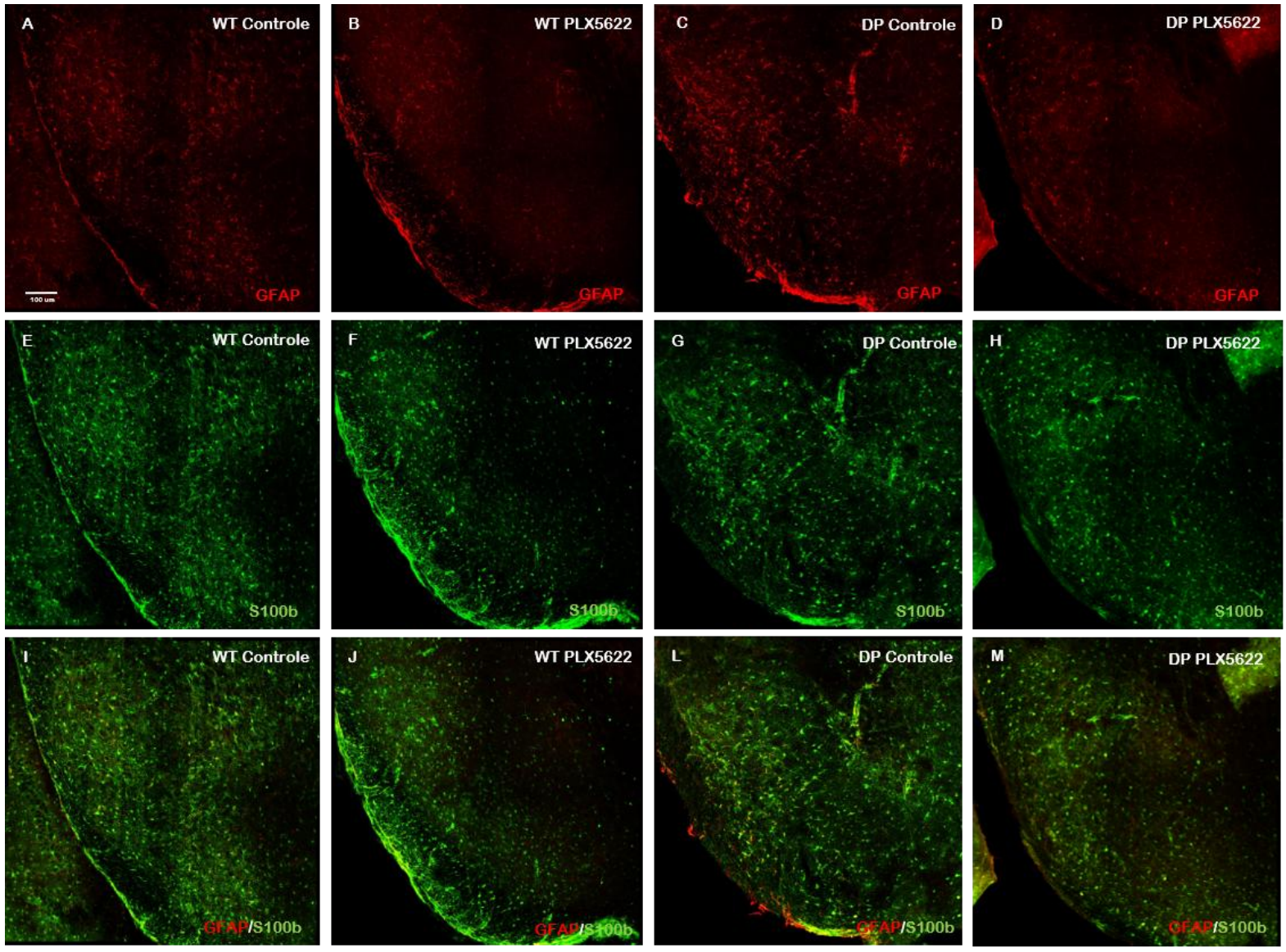

N
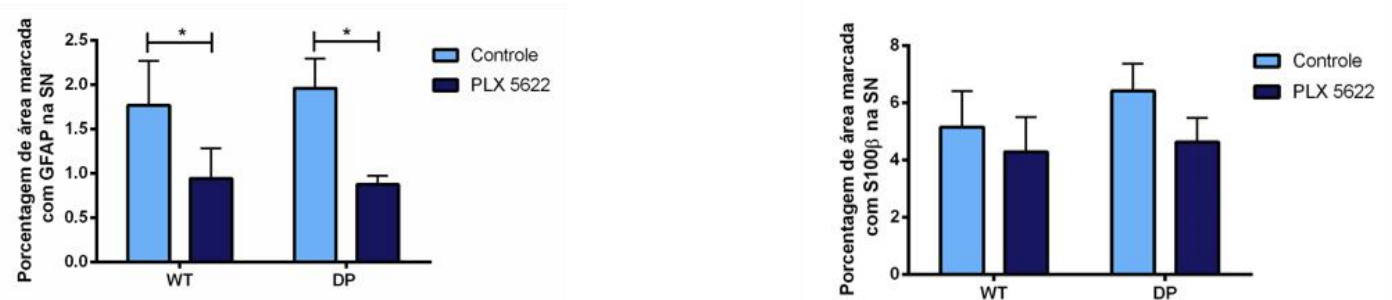

A-D. Imagens imunofluorescentes na SNpc mostrando células positivas para GFAP marcadas em vermelho nos quatro grupos especificados. E-H. Imagens representativas do marcador S100ß em verde. I-M. Imagens mostrando a sobreposição dos marcadores GFAP e S100ß para cada grupo. N. Gráfico mostrando a redução na porcentagem de área marcada por GFAP nos grupos tratados com PLX5622. O. Gráfico mostrando que a porcentagem de área marcada por $S 100 \beta$ não difere entre os grupos. $n=6-7 .{ }^{*} p<0,05$. 


\subsubsection{Estriado}

Diferentemente da SNpc, o CPu dos camundongos com depleção microglial e com DP apresentaram um aumento na porcentagem de área marcada com o anticorpo anti-GFAP $(4,06 \pm 0,63)$ quando comparado com o WT PLX5622 $(1,44 \pm$ 0,27 ) (ANOVA de duas vias; $p=0,014 ; F(3,26)=7,00$ ). Esse efeito não foi observado nos grupos controles, indicando que a redução do número de microglias pode induzir uma resposta astrocítica somente na presença de um processo neuroinflamatório (gráfico $\mathrm{N}$ da figura 33).

Por outro lado, não foi observada interação entre os dois fatores na expressão de $S 100 \beta$ (ANOVA de duas vias; $p=0,67 ; F(3,27)=0,18$ ), entretanto, quando analisado os fatores independentemente, somente a indução de DP foi significante $(p=0,044 ; F(3,27)=4,46)$. Apesar disso, a análise do pós-teste mostrou que não houve diferença entre os grupos. $O$ gráfico $O$ da figura 33 mostrou $O$ aparente aumento da expressão de DP PLX5622 $(8,55 \pm 0,29)$ em relação ao WT PLX5622 $(5,43 \pm 1,10)$, entrentanto, essa diferença não foi significantiva $(p=0,09$; $F(3,27)=3,09)$. 
Figura 33. No CPu, camundongos com depleção microglial e submetidos à 6-OHDA apresentaram aumento da porcentagem de área marcada com GFAP quando comparado com WT PLX5622.
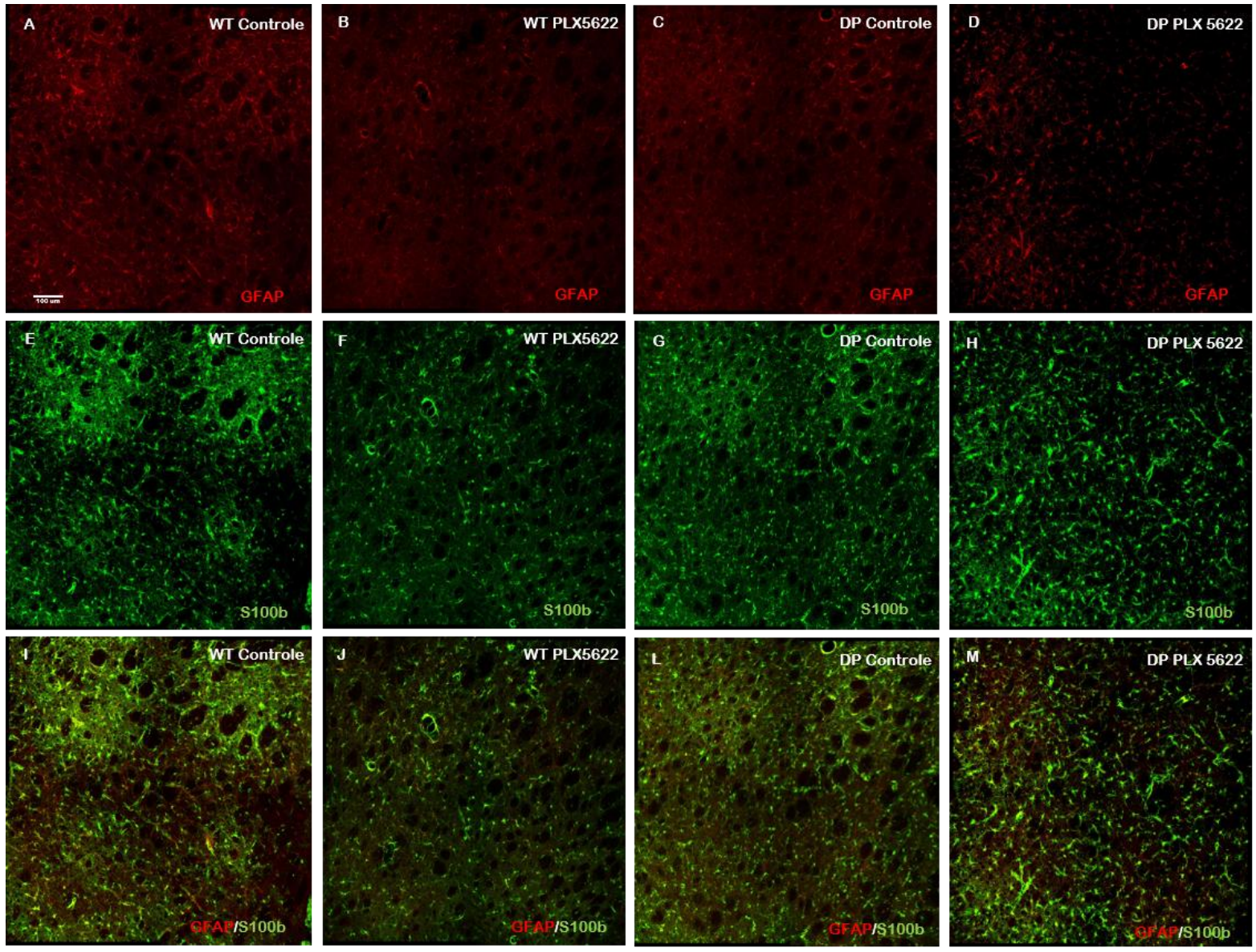

$\mathrm{N}$
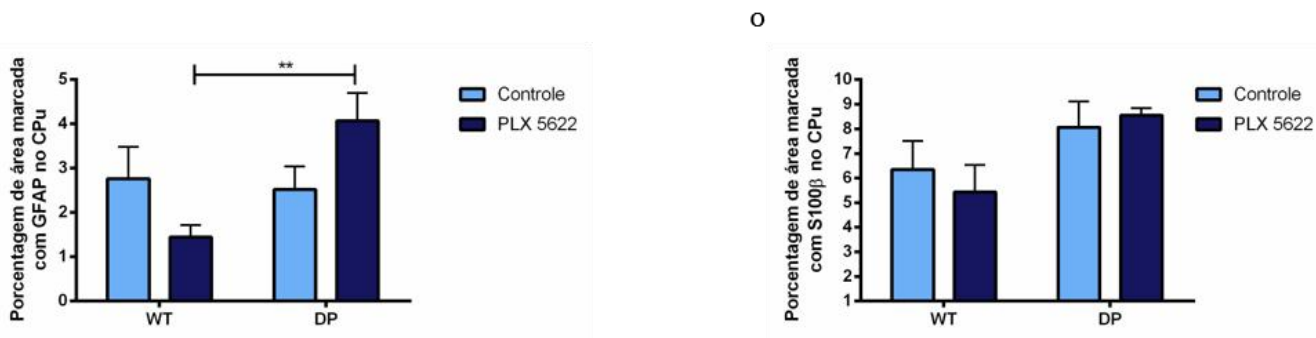

A-D. Imagens representativas do CPu capturadas em aumento de 20x, mostrando a marcação de GFAP em vermelho. E-H. Imagens representativas de $S 100 \beta$ nos quatro grupos. I-M. Imagens mostrando a sobreposição dos marcadores GFAP e S100ß. N. Gráfico mostrando o aumento da área marcada com GFAP no DP PLX5622 quando comparado com o controle. $\mathbf{O}$. Gráfico mostrando que não houve diferença entre a área marcada com 0 anticorpo anti-S100 $\beta$ entre os grupos. $n=6-9 .{ }^{* *} p<0,01$. 


\subsection{Quantificação dos níveis de transcritos na substância negra}

Com o intuito de analisar os transcritos relacionados à via neuropatológica e, por conseguinte, identificar os genes que estão relacionados à microglia e à redução do processo neurodegenerativo foi realizada a quantificação dos níveis de transcritos na SN. A figura 34 contém o diagrama de Venn que ilustra os genes comuns e específicos para cada comparação entre os grupos, que foram: WT controle x WT PLX5622 (círculo verde); WT controle x DP controle (círculo azul) e DP controle $\times$ DP PLX5622 (círculo amarelo). As tabelas apresentam todos os genes que são específicos para cada comparação com a mesma cor do diagrama.

Um dos objetivos desse estudo foi identificar os diferentes níveis de transcritos que são regulados dentro dos grupos DP com o propósito de detectar possíveis alvos envolvidos no processo neurodegenerativo. O painel A da figura 35 mostra o heat map dos genes significativamente diferentes (com valor de $p$ até 0,015 ) entre os grupos DP controle e DP PLX5622, enquanto que o painel B exibe os 27 genes comuns entre os grupos WT controle $\times$ WT PLX5622 e entre DP controle $x$ DP PLX5622, indicando somente os genes ligados à microglia.

Como pode ser observado no painel $\mathrm{B}$, os transcritos específicos para a microglia, que são: Tmem119, P2ry12, Csf1r, Cx3cr1, CD68 and Trem2, apresentaram-se significativamente em baixos níveis nos grupos com depleção microglial e em altos níveis nos controles. Além disso, o nível do transcrito Cybb seguiu o mesmo padrão dos citados acima, o que pode ser um indicativo da importância de Nox2 na função microglial.

Para investigar os genes que estão envolvidos no aumento do processo neurodegenerativo observado em DP PLX5622, foram analisados os níveis dos transcritos em comum e que significativamente estão alterados entre os grupos DP controle x DP PLX5622 e WT controle x DP controle. Como pode ser notado no painel C, os transcritos Trim28, Akt1s1, Mecp2, Erlec1, Polr2j, Phf2 e Adora1 apresentaram níveis elevados no grupo DP controle quando comparado com o WT e baixos níveis no DP PLX5622 quando comparado com o DP controle. Esses genes podem estar relacionados com o aumento da perda de neurônios dopaminérgicos observado em DP PLX5622. Além disso, Sqstm1 é o transcrito da proteína p62/sequestosome-1 adapter que foi recentemente descoberta como um alvo da proteína LRRK-2, um dos genes comuns relacionados ao desenvolvimento da DP 
(147). Os níveis desse transcrito estão elevados no DP controle em relação ao DP PLX5622.

Figura 34. Diagrama de Venn mostrando o número de genes em comum para cada comparação, seguida de tabelas com os genes especificados.

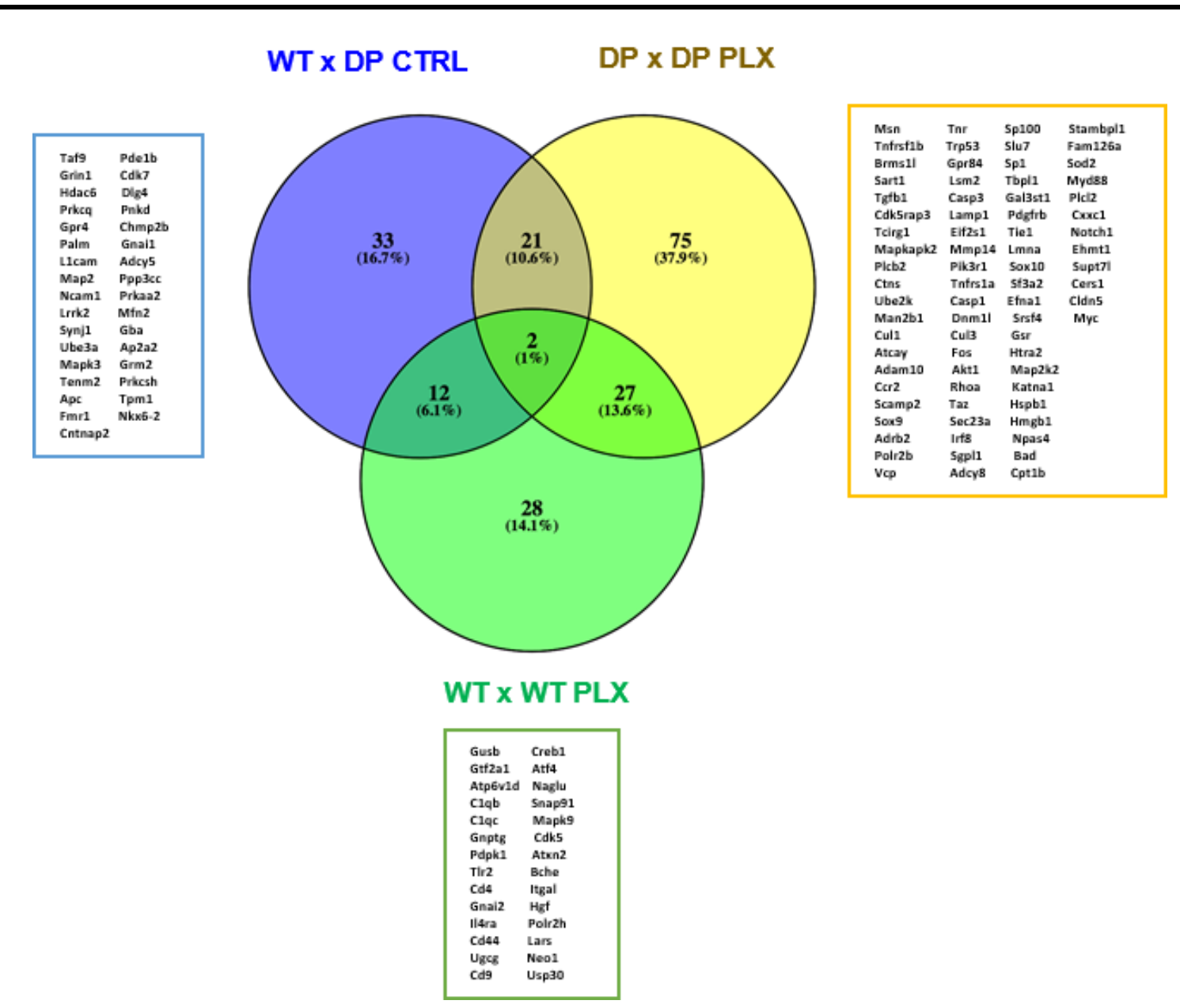

A comparação entre DP controle e DP PLX5622 apresentou 75 genes específicos que estão citados na tabela em amarelo. A tabela verde contém os genes específicos da comparação entre WT controle e WT PLX5622, enquando que a tabela azul exibe os genes da comparação entre WT controle e DP controle. 
Figura 35. Análise do heat map da expressão gênica.

A.

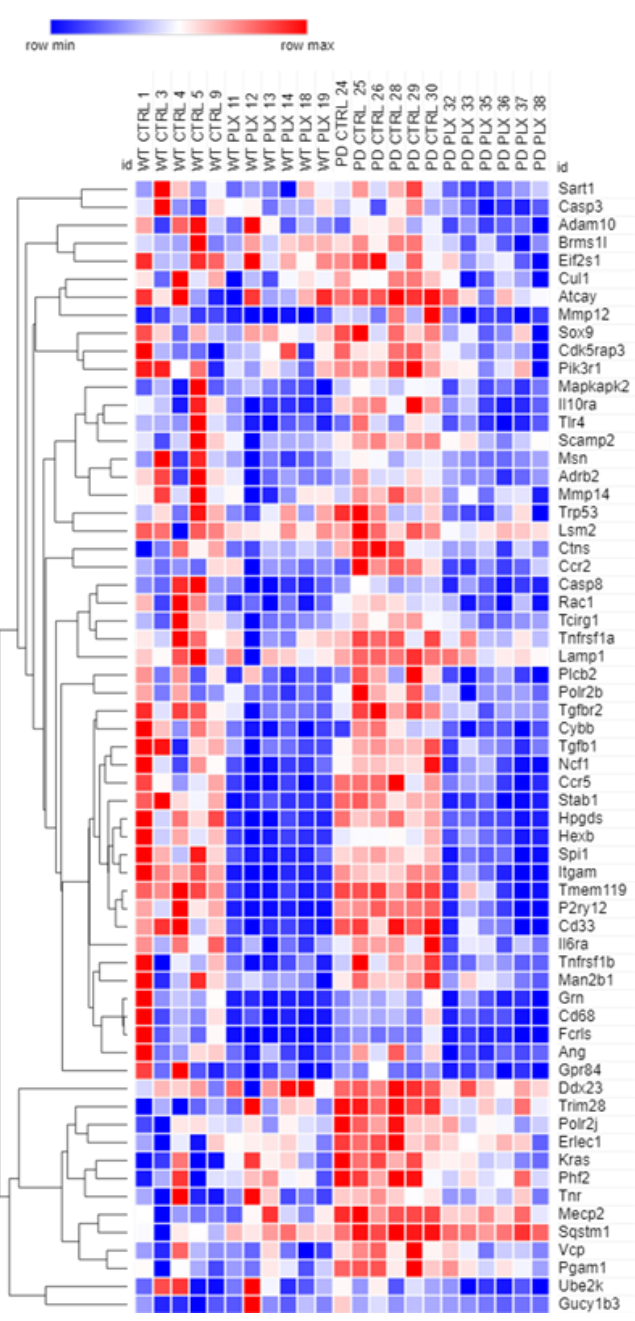

B.

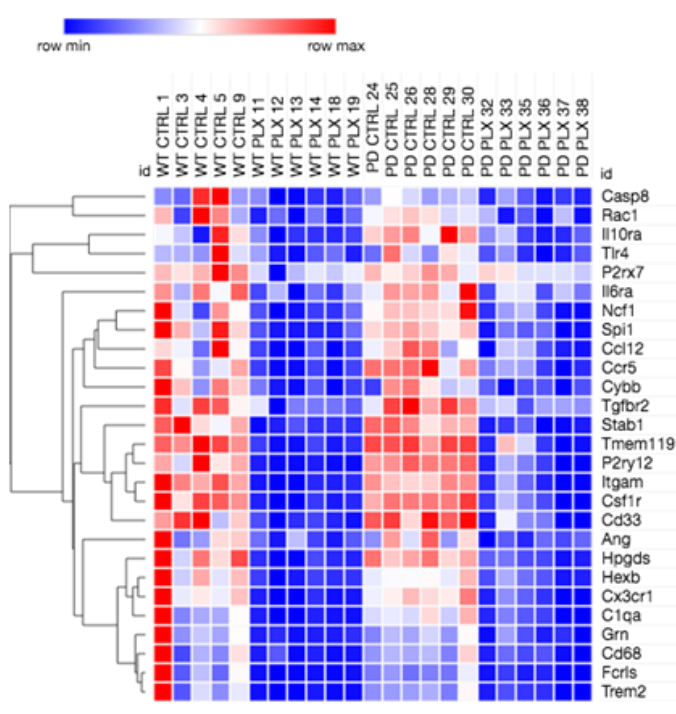

c.

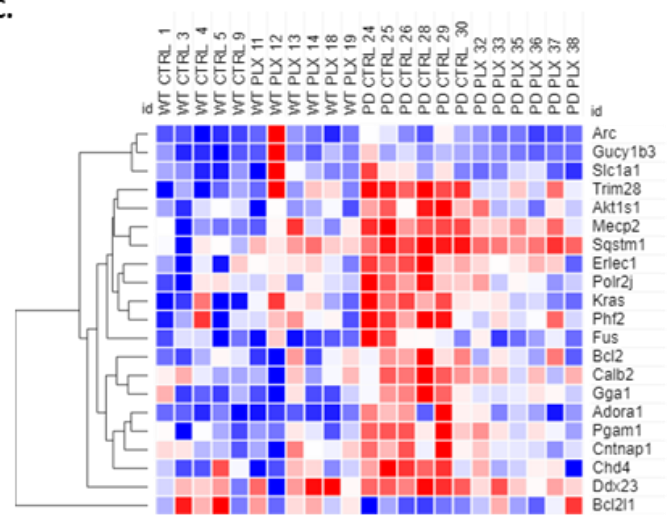

A. Heat map dos genes mais significativos entre os grupos DP controle e DP PLX5622 com valores de $p$ até 0,015 . B. Os 27 genes comuns e nas comparações entre DP controle x DP PLX5622 e entre WT controle $x$ WT PLX5622, indicando os genes relacionados à microglia. C. Os 21 genes em comum nas comparações entre WT controle x DP controle e DP controle x DP PLX5622. 
3.10. Resumo dos resultados

\section{Resultados}

Teste do Poste

Tempo no dia 14: DP PLX>DP CTRL

DP CTRL $>$ WT CTRL

DP PLX $>$ WT PLX

\section{Campo Aberto}

1. Distância Percorrida: Os 4 grupos apresentaram redução no dia 7 e 14 em relação ao baseline

WT PLX $<$ WT CTRL (Baseline e no dia 7)

WT PLX<DP PLX (dia 7)

2. Velocidade Média: Os 4 grupos apresentaram redução no dia 7 e 14 em relação ao baseline

WT PLX $<$ WT CTRL (Baseline e no dia 7)

WT PLX<DP PLX (dia 7)

3. Tempo despendido no perímetro:

DP PLX 7 dias< DP PLX Baseline

DP PLX < WT PLX (7 dias)

4. Tempo despendido no centro:

DP PLX 7 dias< DP PLX Baseline

DP PLX < WT PLX (7 dias)

\section{\begin{tabular}{ll}
\hline Rota Rod & DP CTRL $<$ WT CTRL (7 dias)
\end{tabular}}

\begin{tabular}{ll}
\hline SN - TH & DP CTRL $<$ WT CTRL \\
& DP PLX $<$ WT PLX \\
& DP PLX $<$ DP CTRL
\end{tabular}

SN - lba-1

1. Número:

WT PLX $<$ WT CTRL

DP PLX $<$ DP CTRL

DP CTRL $>$ WT CTRL

2. Área: 


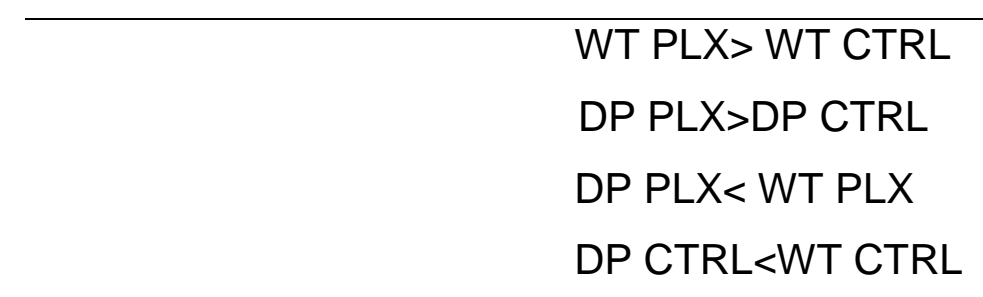

\begin{tabular}{ll}
\hline SN - CD68 & 1. Intensidade: \\
& WT PLX $<$ WT CTRL \\
& DP CTRL $>$ WT CTRL \\
& DP PLX $<$ DP CTRL \\
& DP PLX $>$ WT PLX
\end{tabular}

2. Co-localização com Iba-1:

DP CTRL $>$ WT CTRL

DP PLX>DP CTRL

3. Coeficiente de Pearson:

WT PLX $<$ WT CTRL

DP PLX $>W T$ PLX

\begin{tabular}{ll}
\hline CPu - lba-1 & 1. Número: \\
& WT PLX $<$ WT CTRL \\
& DP PLX $<$ DP CTRL \\
& DP CTRL $>$ WT CTRL \\
& 2. Área: \\
& WT PLX $>$ WT CTRL \\
& DP PLX $>$ DP CTRL \\
& DP PLX $<$ WT PLX \\
& \\
\hline CPu - CD 68 & WT Intensidade: $P L X<W T C T R L$ \\
& DP PLX $<$ DP CTRL
\end{tabular}




\section{Co-localização com Iba-1:}

WT PLX $<$ WT CTRL

DP PLX $<$ DP CTRL

3. Coeficiente de Pearson:

WT PLX $>$ WT CTRL

DP PLX>DP CTRL

\begin{tabular}{ll}
\hline SN - GFAP & WT PLX $<$ WT CTRL \\
& DP PLX $<$ DP CTRL \\
\hline SN - S100ß & Não há diferença entre os grupos \\
\hline CPu - GFAP & DP PLX $>$ WT PLX \\
\hline CPu - S100 & Não há diferença entre os grupos \\
\hline Heat Map & Genes que estão superexpressos no DP CTRL em \\
& $\begin{array}{l}\text { relação ao WT CTRL e pouco expressos no DP PLX em } \\
\text { relação ao DP CTRL: Trim28, Akt1s1, Mecp2, Erlec1, Polr2j, } \\
\text { Phf2 e Adora1 }\end{array}$ \\
\hline
\end{tabular}




\section{DISCUSSÃO}

O presente estudo mostrou que a microglia desempenha um papel fundamental na prevenção da morte neuronal evidenciada no modelo murino de doença de Parkinson utilizando 6-OHDA. A depleção microglial via inibição de CSF1R consiste em um método específico que permite compreender a importância da resposta microglial em doenças neurodegenerativas como as doenças de Alzheimer e de Parkinson. Como observado, a depleção microglial acelerou o comprometimento motor e a perda neuronal na substância negra de camundongos submetidos a 6OHDA. Além disso, microglias remanescentes nos grupos PLX5622 apresentaram marcações das proteínas TMEM119 e P2RY12, que são específicas para esse tipo celular, entretanto, apresentaram redução significativa da expressão de CD68, proteína relacionada à função fagocítica. Também foi evidenciado que a eliminação microglial após 14 dias de indução de DP apresentou efeitos diferentes na resposta astrocítica nas duas regiões analisadas, com expressiva redução na SNpc dos grupos sem microglia e aumento da porcentagem de área somente no CPu do grupo DP PLX5622. Outra contribuição desse estudo foi a análise do NanoString, que teve como objetivo identificar possíveis genes relacionados a preservação dos neurônios dopaminérgicos e com a função microglial. Um desses genes que poderia estar relacionado à notável neurodegeneração na depleção microglial é o MeCP2.

Para avaliar os efeitos da indução por 6-OHDA nas habilidades motoras, os grupos de animais foram submetidos a três diferentes testes comportamentais, sendo eles: o teste do poste, rota rod e campo aberto. Os resultados mostraram que apenas o teste do poste foi sensível aos efeitos da perda neuronal na SNpc, depois de 14 dias da cirurgia com baixa dosagem de 6-OHDA nos dois hemisférios. O teste do poste tem sido usado para avaliar os gânglios basais relacionados às disfunções de movimento (141) (148) e é considerado um dos testes mais robustos para detectar comprometimentos sensoriomotores em modelos murinos de 6-OHDA (115). O estudo de Matsuura e colaboradores (141) mostrou que os níveis de dopamina no estriado estão correlacionados negativamente com a atividade locomotora de escalar o poste depois de 7 dias após a indução por 6-OHDA. Como descrito anteriormente, o grupo DP PLX5622 apresentou o pior desempenho nesse teste comportamental quando comparado com o DP controle no dia 14, indicando que a depleção microglial aumenta a disfunção motora. O mesmo resultado foi 
verificado após 7 dias de indução de MPTP em camundongos submetidos ao tratamento com PLX3397, outro tipo de inibidor de CSF1R (149).

Apesar do rota rod ser considerado o teste comportamental mais usado para avaliar déficits motores $(97,150)$, os resultados mostraram que a redução de latência no tempo de queda da roda só foi significativa no grupo DP controle no dia 7, quando comparado ao WT controle. O comprometimento das habilidades motoras para concluir o teste não foi observado no dia 14, período no qual a degeneração neuronal foi avaliada pelo número de células positivas para $\mathrm{TH}$ na $\mathrm{SNpc}$ e que foi significativamente reduzida nos dois grupos DP. A ausência de sensibilidade do rota rod na avaliação da disfunção motora foi evidenciada anteriormente, quando utilizado para analisar os efeitos de doses moderadas de MPTP (151).

A significativa redução de cerca de $80 \%$ no número de neurônios dopaminérgicos no grupo DP sem microglia, quando comparado com o DP controle, evidencia que a eliminação microglial torna o neurônio mais susceptível a toxicidade desencadeada pelo estresse oxidativo iniciado pela 6-OHDA. Esse fato corrobora com os resultados relatados anteriormente no modelo de MPTP (149). Por isso, células microgliais remanescentes dos grupos submetidos ao PLX5622 foram caracterizadas com o objetivo de identificar se estes grupos apresentam um perfil microglial diferente dos grupos controles. As células remanescentes apresentaram tamanho de área maior quando comparado com os grupos sem depleção microglial. Entretanto, o grupo DP PLX5622 apresentou área celular menor que o WT PLX5622 nas duas regiões analisadas. $O$ aumento do corpo celular pode ser um indicativo do tipo amebóide, porém análises do número e tamanho dos braços microgliais seriam necessários para identificar se essas microglias são de-ramificadas ou não. 0 estudo de Stott e colaboradores mostrou um aumento no tamanho dos braços e no número de endpoints no dia 9 depois da injeção de 6-OHDA em camundongos fêmeas, sendo que esse resultado foi observado até 12 dias após a cirurgia (104).

O nível do transcrito de CD68, bem como, a intensidade desse marcador apresentaram-se reduzidos nos grupos tratados com o inibidor de CSF1R, entretanto o grupo DP PLX5622 mostrou uma alta intensidade na marcação na SNpc, quando comparado com o WT PLX5622. Esses resultados sugerem que a microglia remanescente da SNpc permanece com o perfil fagocítico na presença de 6-OHDA. Em outro modelo de DP, em que foi usado um vetor viral para aumentar a expressão da proteína $\alpha$-syn no mesencéfalo de ratos com o objetivo de reproduzir 
dois estágios da doença, os autores verificaram um aumento de células microgliais CD68+ somente quando a $\alpha$-syn induzia patologia neuronal e morte celular. Essas células fagocíticas não foram evidentes quando não houve morte celular (152). Um estudo temporal em ratos utilizando 6-OHDA mostrou um aumento progressivo de células CD68+ na SN quando a perda neuronal foi identificada, atingindo significância no dia 9 e com aumento expressivo no dia 15 depois da cirurgia (103). Logo, a presença de células microgliais positivas para CD68 está relacionada com o processo neurodegenerativo da DP.

Ademais, foi analisada a resposta astrocítica, uma vez que as células gliais possuem papel duplo na DP, podendo ser neuroprotetor ou neurodegenerativo dependendo das moléculas liberadas por esse tipo celular (153, 154). Um estudo temporal de 6-OHDA em camundongos fêmeas mostrou que a ativação astrocítica na SN é posterior em relação à lesão no estriado, com significativo aumento de células GFAP + somente após 9 dias de cirurgia (104). Por outro lado, os resultados descritos anteriormente mostraram que não houve aumento significativo na porcentagem de área ocupada por células GFAP+ ou S100 $\beta+$ na SN após 14 dias de indução por 6-OHDA, indicando que a ativação astrocítica pode ter ocorrido anteriormente a esse período. Recentemente, foi demonstrado que, nos estágios iniciais da toxicidade de 6-OHDA no estriado, os astrócitos são importantes no processamento de debris provenientes a partir da degeneração dopaminérgica através de um mecanismo chamado transautofagia (155). Assim, se a metabolização dos debris pelos astrócitos não ocorrer corretamente, a ativação microglial seria necessária para completar o processo fagocítico, acelerando o início ou a progressão da neurodegeneração (155).

A interação entre microglia e astrócito desempenha papéis importantes na fisiologia cerebral, como por exemplo, a modulação sináptica. Pascual e co-autores mostraram que a ativação microglial por LPS produz moléculas de ATP que, por sua vez, estimulam astrócitos a liberarem glutamato, importante modulador de sinapses excitatórias (156). A eliminação microglial reduziu significativamente o número de células GFAP+ na SNpc, indicando que o número de um tipo de célula glial influencia o número da outra, bem como que a redução dessas células gliais poderia ser prejudicial para a sobrevivência neuronal na presença do estresse oxidativo.

A partir da análise do NanoString, foram observados o aumento dos níveis dos transcritos Trim28, Akt1s1, Mecp2, Erlec1, Polr2j, Phf2 and Adora1 no grupo DP 
controle em relação ao WT, bem como, a redução desses transcritos no DP PLX5622 quando comparado com o grupo DP controle. Esses resultados apontaram esses genes como sendo os possíveis envolvidos no mecanismo de perda neuronal. O gene MeCP2 está relacionado com a Síndrome de Rett (RTT), uma doença que no seu estágio mais avançado tem perda de habilidades motoras semelhantes ao Parkinson, como a aceleração involuntária, distonia e inércia $(157,158)$. Alguns estudos mostraram uma relação entre a depleção do gene MeCP2 com o comprometimento da via nigroestriatal (159, 160). Samaco e colaboradores (160) mostraram que neurônios $\mathrm{TH}+$ com o gene MeCP2 depletado apresentou redução significativa da intensidade de marcação de TH na região do mesencéfalo contendo a SNpc, dos níveis de dopamina e dos níveis de expressão de Th. Ademais, eles verificaram que o MeCP2 ocupava o sítio do promotor de Th, regulando diretamente a síntese da expressão de dopamina. O papel do gene MeCP2 no modelo de DP foi investigado in vitro, mostrando que a presença de 6-OHDA em células SH-SY5Y resultou em uma significativa redução das proteínas TH e MeCP2, enquanto que a overexpressão de MeCP2 aumentou os níveis da expressão de TH e teve um papel protetor contra a apoptose(161). Além disso, outro trabalho mostrou que o transplante da medula óssea de um camundongo WT em um camundongo Mecp2 $^{-/ y}$ melhorou alguns dos déficits motores associados ao modelo transgênico, como o tremor involuntário e a locomoção (162), indicando que a microglia sem mutações no gene MeCP2 reverte as disfunções motoras causadas pela ausência do gene no neurônio. A partir dos resultados obtidos no presente estudo pode-se sugerir que as microglias remanescentes do tratamento com o inibidor CSF1R não são suficientes para reparar o dano causado pelo estresse oxidativo iniciado pela 6OHDA, bem como, para reverter o efeito da baixa expressão dos níveis de MeCP2.

Portanto, este estudo contribuiu para a melhor compreensão do papel da microglia durante a perda de neurônios dopaminérgicos em um modelo específico da doença de Parkinson. Os resultados estão de acordo com trabalhos da literatura, uma vez que mostra que a depleção microglial acelera o comprometimento das habilidades motoras e agrava a perda dos neurônios TH+. Além disso, sugere-se que dois fatores foram determinantes para a aceleração do processo neurodegenerativo, sendo eles: 1) a redução da interação entre astrócito e microglia, fundamental para a função neuronal e para a modulação sináptica; 2) a baixa 
regulação da expressão do gene $M e C P 2$ na SNpc, importante para a modulação da via nigroestriatal. 


\section{CONCLUSÕES GERAIS}

A partir dos resultados obtidos nos dois capítulos desse trabalho, pode-se concluir que:

- A ausência da subunidade gp91 ${ }^{\text {phox }}$ da Nox2 impediu a morte expressiva dos neurônios dopaminérgicos e, por conseguinte, protegeu os animais de um declínio motor. A partir dos resultados da ativação microglial em função do processo neurodegenerativo, pode-se afirmar que a ativação precoce da enzima iNOS conjuntamente com a da Nox2 na microglia dos animais selvagens aumenta os níveis de EROs, tornando o neurônio mais susceptível à morte celular causada pela 6-OHDA.

- Com relação ao estudo que verificou o impacto da depleção microglial por meio da inibição de CSF1R (PLX5622) no processo neurodegenerativo causado pela 6-OHDA, pode-se inferir que a ausência da microglia acelerou a morte dos neurônios dopaminérgicos, levando a um déficit motor significativo. Alguns dos fatores que podem ter contribuído para isso foram: a redução na comunicação entre microglia e astrócitos; e a diminuição do nível dos transcritos do gene MeCP2, que está relacionado a via nigroestriatal. 


\section{REFERÊNCIAS}

1. Instituto Brasileiro de Geografia e Estatística 2009 [updated 2009; cited 201302 de dezembro ]; Available from: http://www.ibge.gov.br/home/estatistica/populacao/indic sociosaude/2009/indicsaud e.pdf.

2. Ascherio A, Schwarzschild MA. The epidemiology of Parkinson's disease: risk factors and prevention. Lancet Neurol. $2016 \mathrm{Nov}$;15(12):1257-72.

3. Dorsey ER, Constantinescu R, Thompson JP, Biglan KM, Holloway RG, Kieburtz $\mathrm{K}$, et al. Projected number of people with Parkinson disease in the most populous nations, 2005 through 2030. Neurology. 2007 Jan 30;68(5):384-6.

4. de Lau LMLaB, M.B.M. Epidemiology of Parkinson's disease Lancet Neurology 2006;5:525-35.

5. Barbosa MT, Caramelli P, Maia DP, Cunningham MC, Guerra HL, Lima-Costa MF, et al. Parkinsonism and Parkinson's disease in the elderly: a community-based survey in Brazil (the Bambui study). Mov Disord. 2006 Jun;21(6):800-8.

6. Goedert M, Spillantini MG, Del Tredici K, Braak H. 100 years of Lewy pathology. Nat Rev Neurol. 2013 Jan;9(1):13-24.

7. Schapira AH. Science, medicine, and the future: Parkinson's disease. BMJ. 1999 Jan 30;318(7179):311-4.

8. American Psychiatric Association: Diagnostic and Statistical Manual of Mental Disorders Washington, D.C. : American Psychiatric Association; 1994 [cited.

9. Vajda FJ. Neuroprotection and neurodegenerative disease. J Clin Neurosci. 2002 Jan;9(1):4-8.

10.Forno LS. Neuropathology of Parkinson's disease. J Neuropathol Exp Neurol. 1996 Mar;55(3):259-72.

11.Spillantini MG, Crowther RA, Jakes R, Hasegawa M, Goedert M. alpha-Synuclein in filamentous inclusions of Lewy bodies from Parkinson's disease and dementia with lewy bodies. Proc Natl Acad Sci U S A. 1998 May 26;95(11):6469-73.

12.Maroteaux L, Campanelli JT, Scheller RH. Synuclein: a neuron-specific protein localized to the nucleus and presynaptic nerve terminal. J Neurosci. 1988 Aug;8(8):2804-15.

*De acordo com: International Committee of Medical Journal Editors. Uniform requirements for manuscripts submitted to Biomedical Journals: sample references. 2003 [atualizado em 02 de maio de 2018]. Disponível em: https://www.nlm.nih.gov/bsd/uniform requirements.html 
13.Guardia-Laguarta C, Area-Gomez E, Rub C, Liu Y, Magrane J, Becker D, et al. alpha-Synuclein is localized to mitochondria-associated ER membranes. J Neurosci. 2014 Jan 1;34(1):249-59.

14. Recasens A, Dehay B. Alpha-synuclein spreading in Parkinson's disease. Front Neuroanat. 2014;8:159.

15.Kalia LV, Lang AE. Parkinson's disease. Lancet. 2015 Aug 29;386(9996):896912.

16.Lesage S, Brice A. Role of mendelian genes in "sporadic" Parkinson's disease. Parkinsonism Relat Disord. 2011 Jan;18 Suppl 1:S66-70.

17.Taetzsch T, Block ML. Pesticides, microglial NOX2, and Parkinson's disease. J Biochem Mol Toxicol. 2013 Feb;27(2):137-49.

18.Blandini F, Nappi G, Tassorelli C, Martignoni E. Functional changes of the basal ganglia circuitry in Parkinson's disease. Prog Neurobiol. 2000 Sep;62(1):63-88.

19. Oertel WH, Mugnaini E. Immunocytochemical studies of GABAergic neurons in rat basal ganglia and their relations to other neuronal systems. Neurosci Lett. 1984 Jun $29 ; 47(3): 233-8$.

20.Calabresi P, Picconi B, Tozzi A, Ghiglieri V, Di Filippo M. Direct and indirect pathways of basal ganglia: a critical reappraisal. Nat Neurosci. 2014 Aug;17(8):1022-30.

21.Galvan A, Devergnas A, Wichmann T. Alterations in neuronal activity in basal ganglia-thalamocortical circuits in the parkinsonian state. 2015 Front Neuroanat.9:5.

22.Surmeier DJ, Graves SM, Shen W. Dopaminergic modulation of striatal networks in health and Parkinson's disease. Curr Opin Neurobiol. 2014 Dec;29:109-17.

23.Przedborski S, Ischiropoulos $\mathrm{H}$. Reactive oxygen and nitrogen species: weapons of neuronal destruction in models of Parkinson's disease. Antioxid Redox Signal. 2005 May-Jun;7(5-6):685-93.

24.Blum D, Torch S, Lambeng N, Nissou M, Benabid AL, Sadoul R, et al. Molecular pathways involved in the neurotoxicity of 6-OHDA, dopamine and MPTP: contribution to the apoptotic theory in Parkinson's disease. Prog Neurobiol. 2001 Oct;65(2):13572.

25.Rodriguez-Pallares J, Parga JA, Munoz A, Rey P, Guerra MJ, Labandeira-Garcia JL. Mechanism of 6-hydroxydopamine neurotoxicity: the role of NADPH oxidase and microglial activation in 6-hydroxydopamine-induced degeneration of dopaminergic neurons. J Neurochem. 2007 Oct;103(1):145-56.

26.Ungerstedt U. 6-Hydroxy-dopamine induced degeneration of central monoamine neurons. Eur J Pharmacol. 1968 Dec;5(1):107-10. 
27.Sauer $\mathrm{H}$, Oertel WH. Progressive degeneration of nigrostriatal dopamine neurons following intrastriatal terminal lesions with 6-hydroxydopamine: a combined retrograde tracing and immunocytochemical study in the rat. Neuroscience. 1994 Mar;59(2):401-15.

28.Andrew R, Watson DG, Best SA, Midgley JM, Wenlong $H$, Petty RK. The determination of hydroxydopamines and other trace amines in the urine of parkinsonian patients and normal controls. Neurochem Res. 1993 Nov;18(11):11757.

29.Linert W, Herlinger E, Jameson RF, Kienzl E, Jellinger K, Youdim MB. Dopamine, 6-hydroxydopamine, iron, and dioxygen--their mutual interactions and possible implication in the development of Parkinson's disease. Biochim Biophys Acta. 1996 Aug 23;1316(3):160-8.

30.Salonen T, Haapalinna A, Heinonen E, Suhonen J, Hervonen A. Monoamine oxidase $B$ inhibitor selegiline protects young and aged rat peripheral sympathetic neurons against 6-hydroxydopamine-induced neurotoxicity. Acta Neuropathol. 1996;91(5):466-74.

31.Soto-Otero R, Mendez-Alvarez E, Hermida-Ameijeiras A, Munoz-Patino AM, Labandeira-Garcia JL. Autoxidation and neurotoxicity of 6-hydroxydopamine in the presence of some antioxidants: potential implication in relation to the pathogenesis of Parkinson's disease. J Neurochem. 2000 Apr;74(4):1605-12.

32. Heikkila R, Cohen G. Inhibition of biogenic amine uptake by hydrogen peroxide: a mechanism for toxic effects of 6-hydroxydopamine. Science. 1971 Jun $18 ; 172(3989): 1257-8$.

33. Heikkila RE, Cohen G. 6-Hydroxydopamine: evidence for superoxide radical as an oxidative intermediate. Science. 1973 Aug 3;181(4098):456-7.

34.Perumal AS, Gopal VB, Tordzro WK, Cooper TB, Cadet JL. Vitamin E attenuates the toxic effects of 6-hydroxydopamine on free radical scavenging systems in rat brain. Brain Res Bull. 1992 Nov;29(5):699-701.

35.Glinka YY, Youdim MB. Inhibition of mitochondrial complexes I and IV by 6hydroxydopamine. Eur J Pharmacol. 1995 Mar 16;292(3-4):329-32.

36.Schober A. Classic toxin-induced animal models of Parkinson's disease: 6-OHDA and MPTP. Cell Tissue Res. 2004 Oct;318(1):215-24.

37.Blandini F, Armentero MT, Martignoni E. The 6-hydroxydopamine model: news from the past. Parkinsonism Relat Disord. 2008;14 Suppl 2:S124-9.

38. Wyss-Coray T, Mucke L. Inflammation in neurodegenerative disease--a doubleedged sword. Neuron. 2002 Aug 1;35(3):419-32. 
39.Liu B, Hong JS. Role of microglia in inflammation-mediated neurodegenerative diseases: mechanisms and strategies for therapeutic intervention. J Pharmacol Exp Ther. 2003 Jan;304(1):1-7.

40.Purisai MG, McCormack AL, Cumine S, Li J, Isla MZ, Di Monte DA. Microglial activation as a priming event leading to paraquat-induced dopaminergic cell degeneration. Neurobiol Dis. 2007 Feb;25(2):392-400.

41. Glezer I, Simard AR, Rivest S. Neuroprotective role of the innate immune system by microglia. Neuroscience. 2007 Jul 29;147(4):867-83.

42.Schwartz M, Ziv Y. Immunity to self and self-maintenance: a unified theory of brain pathologies. Trends Immunol. 2008 May;29(5):211-9.

43.Gao HM, Hong JS. Why neurodegenerative diseases are progressive: uncontrolled inflammation drives disease progression. Trends Immunol. 2008 Aug;29(8):357-65.

44.McGeer PL, Itagaki S, Boyes BE, McGeer EG. Reactive microglia are positive for HLA-DR in the substantia nigra of Parkinson's and Alzheimer's disease brains. Neurology. 1988 Aug;38(8):1285-91.

45.Wirenfeldt M, Babcock AA, Vinters HV. Microglia - insights into immune system structure, function, and reactivity in the central nervous system. Histol Histopathol. 2011 Apr;26(4):519-30.

46.Alliot F, Godin I, Pessac B. Microglia derive from progenitors, originating from the yolk sac, and which proliferate in the brain. Brain Res Dev Brain Res. 1999 Nov $18 ; 117(2): 145-52$.

47.Kierdorf K, Erny D, Goldmann T, Sander V, Schulz C, Perdiguero EG, et al. Microglia emerge from erythromyeloid precursors via Pu.1- and Irf8-dependent pathways. Nat Neurosci. 2013 Mar;16(3):273-80.

48. Hanisch UK, Kettenmann H. Microglia: active sensor and versatile effector cells in the normal and pathologic brain. Nat Neurosci. 2007 Nov;10(11):1387-94.

49.Boche D, Perry VH, Nicoll JA. Review: activation patterns of microglia and their identification in the human brain. Neuropathol Appl Neurobiol. 2013 Feb;39(1):3-18.

50.Nimmerjahn A, Kirchhoff F, Helmchen F. Resting microglial cells are highly dynamic surveillants of brain parenchyma in vivo. Science. 2005 May $27 ; 308(5726): 1314-8$.

51.Brown GC, Vilalta A. How microglia kill neurons. Brain Res. 2015 Dec 2;1628(Pt B):288-97.

52.Korzhevskii DE, Kirik OV. Brain microglia and microglial markers. Neuroscience and Behavioral Physiology. 2016;46(3):284-90. 
53.Ito D, Imai Y, Ohsawa K, Nakajima K, Fukuuchi Y, Kohsaka S. Microglia-specific localisation of a novel calcium binding protein, Iba1. Brain Res Mol Brain Res. 1998 Jun $1 ; 57(1): 1-9$.

54.Sasaki A. Microglia and brain macrophages: An update. Neuropathology. 2016 Oct;37(5):452-64.

55.Holness CL, da Silva RP, Fawcett J, Gordon S, Simmons DL. Macrosialin, a mouse macrophage-restricted glycoprotein, is a member of the lamp/lgp family. $\mathrm{J}$ Biol Chem. 1993 May 5;268(13):9661-6.

56.da Silva RP, Gordon S. Phagocytosis stimulates alternative glycosylation of macrosialin (mouse CD68), a macrophage-specific endosomal protein. Biochem J. 1999 Mar 15;338 ( Pt 3):687-94.

57.Perego C, Fumagalli S, De Simoni MG. Temporal pattern of expression and colocalization of microglia/macrophage phenotype markers following brain ischemic injury in mice. J Neuroinflammation. 2011;8:174.

58.Bennett ML, Bennett FC, Liddelow SA, Ajami B, Zamanian JL, Fernhoff NB, et al. New tools for studying microglia in the mouse and human CNS. Proc Natl Acad Sci $U$ S A. 2016 Mar 22;113(12):E1738-46.

59.Satoh J, Kino Y, Asahina N, Takitani M, Miyoshi J, Ishida T, et al. TMEM119 marks a subset of microglia in the human brain. Neuropathology. 2015 Feb;36(1):3949.

60.Saijo K, Crotti A, Glass CK. Regulation of microglia activation and deactivation by nuclear receptors. Glia. 2012 Jan;61(1):104-11.

61. Varnum MM, Ikezu T. The classification of microglial activation phenotypes on neurodegeneration and regeneration in Alzheimer's disease brain. Arch Immunol Ther Exp (Warsz). 2012 Aug;60(4):251-66.

62.Benoit M, Desnues B, Mege JL. Macrophage polarization in bacterial infections. J Immunol. 2008 Sep 15;181(6):3733-9.

63.Brown GC. Mechanisms of inflammatory neurodegeneration: iNOS and NADPH oxidase. Biochem Soc Trans. 2007 Nov;35(Pt 5):1119-21.

64.Colonna M, Butovsky O. Microglia Function in the Central Nervous System During Health and Neurodegeneration. Annu Rev Immunol. 2017 Apr 26;35:441-68.

65.Mantovani A, Sica A, Sozzani S, Allavena P, Vecchi A, Locati M. The chemokine system in diverse forms of macrophage activation and polarization. Trends Immunol. 2004 Dec;25(12):677-86.

66.Paolicelli RC, Bolasco G, Pagani F, Maggi L, Scianni M, Panzanelli P, et al. Synaptic pruning by microglia is necessary for normal brain development. Science. 2011 Sep 9;333(6048):1456-8. 
67.Marin-Teva JL, Dusart I, Colin C, Gervais A, van Rooijen N, Mallat M. Microglia promote the death of developing Purkinje cells. Neuron. 2004 Feb 19;41(4):535-47.

68.Aarum J, Sandberg K, Haeberlein SL, Persson MA. Migration and differentiation of neural precursor cells can be directed by microglia. Proc Natl Acad Sci U S A. 2003 Dec 23;100(26):15983-8.

69.Zhong Y, Zhou LJ, Ren WJ, Xin WJ, Li YY, Zhang T, et al. The direction of synaptic plasticity mediated by $\mathrm{C}$-fibers in spinal dorsal horn is decided by Src-family kinases in microglia: the role of tumor necrosis factor-alpha. Brain Behav Immun. 2010 Aug;24(6):874-80.

70.Morgan SC, Taylor DL, Pocock JM. Microglia release activators of neuronal proliferation mediated by activation of mitogen-activated protein kinase, phosphatidylinositol-3-kinase/Akt and delta-Notch signalling cascades. J Neurochem. 2004 Jul;90(1):89-101.

71.Wes PD, Holtman IR, Boddeke EW, Moller T, Eggen BJ. Next generation transcriptomics and genomics elucidate biological complexity of microglia in health and disease. Glia. 2015 Feb;64(2):197-213.

72.Wolf SA, Boddeke HW, Kettenmann H. Microglia in Physiology and Disease. Annu Rev Physiol. 2016 Feb 10;79:619-43.

73.Imamura K, Hishikawa N, Sawada M, Nagatsu T, Yoshida M, Hashizume Y. Distribution of major histocompatibility complex class II-positive microglia and cytokine profile of Parkinson's disease brains. Acta Neuropathol. 2003 Dec;106(6):518-26.

74.Croisier E, Moran LB, Dexter DT, Pearce RK, Graeber MB. Microglial inflammation in the parkinsonian substantia nigra: relationship to alpha-synuclein deposition. J Neuroinflammation. 2005 Jun 3;2:14.

75.Knott C, Stern G, Wilkin GP. Inflammatory regulators in Parkinson's disease: iNOS, lipocortin-1, and cyclooxygenases-1 and -2. Mol Cell Neurosci. 2000 Dec;16(6):724-39.

76. Hunot S, Dugas N, Faucheux B, Hartmann A, Tardieu M, Debre P, et al. FcepsilonRII/CD23 is expressed in Parkinson's disease and induces, in vitro, production of nitric oxide and tumor necrosis factor-alpha in glial cells. J Neurosci. 1999 May 1;19(9):3440-7.

77.Brodacki B, Staszewski J, Toczylowska B, Kozlowska E, Drela N, Chalimoniuk M, et al. Serum interleukin (IL-2, IL-10, IL-6, IL-4), TNFalpha, and INFgamma concentrations are elevated in patients with atypical and idiopathic parkinsonism. Neurosci Lett. 2008 Aug 22;441(2):158-62.

78.Mogi $M$, Harada $M$, Narabayashi $H$, Inagaki $H$, Minami M, Nagatsu T. Interleukin (IL)-1 beta, IL-2, IL-4, IL-6 and transforming growth factor-alpha levels are elevated in 
ventricular cerebrospinal fluid in juvenile parkinsonism and Parkinson's disease. Neurosci Lett. 1996 Jun 14;211(1):13-6.

79.Joers V, Tansey MG, Mulas G, Carta AR. Microglial phenotypes in Parkinson's disease and animal models of the disease. Prog Neurobiol. 2016 Aug;155:57-75.

80.Bedard $\mathrm{K}$, Krause $\mathrm{KH}$. The NOX family of ROS-generating NADPH oxidases: physiology and pathophysiology. Physiol Rev. 2007 Jan;87(1):245-313.

81.Cahill-Smith S, Li JM. Oxidative stress, redox signalling and endothelial dysfunction in ageing-related neurodegenerative diseases: a role of NADPH oxidase 2. Br J Clin Pharmacol. 2014 Sep;78(3):441-53.

82.Sorce S, Krause $\mathrm{KH}$. NOX enzymes in the central nervous system: from signaling to disease. Antioxid Redox Signal. 2009 Oct;11(10):2481-504.

83. Hernandes MS, Britto LR. NADPH oxidase and neurodegeneration. Curr Neuropharmacol. 2012 Dec;10(4):321-7.

84.Lambeth JD. NOX enzymes and the biology of reactive oxygen. Nat Rev Immunol. 2004 Mar;4(3):181-9.

85.Tejada-Simon MV, Serrano F, Villasana LE, Kanterewicz BI, Wu GY, Quinn MT, et al. Synaptic localization of a functional NADPH oxidase in the mouse hippocampus. Mol Cell Neurosci. 2005 May;29(1):97-106.

86. Nayernia Z, Jaquet V, Krause $\mathrm{KH}$. New insights on NOX enzymes in the central nervous system. Antioxid Redox Signal. 2014 Jun 10;20(17):2815-37.

87. Ejlerskov P, Christensen DP, Beyaie D, Burritt JB, Paclet MH, Gorlach $A$, et al. NADPH oxidase is internalized by clathrin-coated pits and localizes to a Rab27A/B GTPase-regulated secretory compartment in activated macrophages. J Biol Chem. 2012 Feb 10;287(7):4835-52.

88. Lelli A, Gervais A, Colin C, Cheret C, Ruiz de Almodovar C, Carmeliet P, et al. The NADPH oxidase Nox2 regulates VEGFR1/CSF-1R-mediated microglial chemotaxis and promotes early postnatal infiltration of phagocytes in the subventricular zone of the mouse cerebral cortex. Glia. 2013 Sep;61(9):1542-55.

89.Wang X, Michaelis EK. Selective neuronal vulnerability to oxidative stress in the brain. Front Aging Neurosci.2010 March; 2:12.

90.Lull ME, Block ML. Microglial activation and chronic neurodegeneration. Neurotherapeutics. 2010 Oct;7(4):354-65.

91.Gao HM, Liu B, Hong JS. Critical role for microglial NADPH oxidase in rotenoneinduced degeneration of dopaminergic neurons. J Neurosci. 2003 Jul $16 ; 23(15): 6181-7$. 
92.Wu DC, Teismann $P$, Tieu K, Vila $M$, Jackson-Lewis $V$, Ischiropoulos $H$, et al. NADPH oxidase mediates oxidative stress in the 1-methyl-4-phenyl-1,2,3,6tetrahydropyridine model of Parkinson's disease. Proc Natl Acad Sci U S A. 2003 May 13;100(10):6145-50.

93. Hernandes MS, Cafe-Mendes CC, Britto LR. NADPH oxidase and the degeneration of dopaminergic neurons in parkinsonian mice. Oxid Med Cell Longev. 2013;2013:157857.

94.Rappold PM, Cui M, Chesser AS, Tibbett J, Grima JC, Duan L, et al. Paraquat neurotoxicity is mediated by the dopamine transporter and organic cation transporter3. Proc Natl Acad Sci U S A. 2011 Dec 20;108(51):20766-71.

95. Hernandes MS, Santos GD, Cafe-Mendes CC, Lima LS, Scavone C, Munhoz CD, et al. Microglial cells are involved in the susceptibility of NADPH oxidase knockout mice to 6-hydroxy-dopamine-induced neurodegeneration. PLoS One. 2013;8(9):e75532.

96.Paxinos G, Franklin K. The Mouse Brain in Stereotaxic Coordinates. New York Academic Press; 2007.

97.Mann A, Chesselet M. Chapter 8 - Techniques for Motor Assessment in Rodents Movement Disorders (Second Edition) 2014:139-57.

98.Lee CS, Sauer H, Bjorklund A. Dopaminergic neuronal degeneration and motor impairments following axon terminal lesion by instrastriatal 6-hydroxydopamine in the rat. Neuroscience. 1996 Jun;72(3):641-53.

99.Tillerson JL, Cohen AD, Philhower J, Miller GW, Zigmond MJ, Schallert T. Forced limb-use effects on the behavioral and neurochemical effects of 6-hydroxydopamine. J Neurosci. 2001 Jun 15;21(12):4427-35.

100. Scharllet T, Tillerson JL. Intervention Strategies for Degeneration of Dopamine Neurons in Parkinsonism: Optimizing Behavioral Assessment of Outcome. In: Emerich DFDI, R. L.; Sanberg, P. R., editor. Central Nervous System Diseases. New York Humana Press Inc; 2000.

101. Kovalenko OA, Santos JH. Analysis of oxidative damage by gene-specific quantitative PCR. Curr Protoc Hum Genet. 2009 Jul;Chapter 19:Unit 191.

102. Schmued LC, Fallon JH. Fluoro-Gold: a new fluorescent retrograde axonal tracer with numerous unique properties. Brain Res. 1986 Jul 2;377(1):147-54.

103. Marinova-Mutafchieva L, Sadeghian M, Broom L, Davis JB, Medhurst AD, Dexter DT. Relationship between microglial activation and dopaminergic neuronal loss in the substantia nigra: a time course study in a 6-hydroxydopamine model of Parkinson's disease. J Neurochem. 2009 Aug;110(3):966-75. 
104. Stott SR, Barker RA. Time course of dopamine neuron loss and glial response in the 6-OHDA striatal mouse model of Parkinson's disease. Eur J Neurosci. 2014 Mar;39(6):1042-56.

105. Saha RN, Pahan K. Regulation of inducible nitric oxide synthase gene in glial cells. Antioxid Redox Signal. 2006 May-Jun;8(5-6):929-47.

106. Schappi MG, Jaquet V, Belli DC, Krause KH. Hyperinflammation in chronic granulomatous disease and anti-inflammatory role of the phagocyte NADPH oxidase. Semin Immunopathol. 2008 Jul;30(3):255-71.

107. Pomilio C, Pavia P, Gorojod RM, Vinuesa A, Alaimo A, Galvan V, et al. Glial alterations from early to late stages in a model of Alzheimer's disease: Evidence of autophagy involvement in Abeta internalization. Hippocampus. 2015 Feb;26(2):194210.

108. Murphy S. Production of nitric oxide by glial cells: regulation and potential roles in the CNS. Glia. 2000 Jan 1;29(1):1-13.

109. Xue $Q$, Yan $Y$, Zhang $R$, Xiong $H$. Regulation of iNOS on Immune Cells and Its Role in Diseases. Int J Mol Sci. 2018;19(12).

110. Liberatore GT, Jackson-Lewis V, Vukosavic S, Mandir AS, Vila M, McAuliffe $W G$, et al. Inducible nitric oxide synthase stimulates dopaminergic neurodegeneration in the MPTP model of Parkinson disease. Nat Med. 1999 Dec;5(12):1403-9.

111. Mander P, Brown GC. Activation of microglial NADPH oxidase is synergistic with glial iNOS expression in inducing neuronal death: a dual-key mechanism of inflammatory neurodegeneration. J Neuroinflammation. 2005 Sep 12;2:20.

112. Ungerstedt U, Arbuthnott GW. Quantitative recording of rotational behavior in rats after 6-hydroxy-dopamine lesions of the nigrostriatal dopamine system. Brain Res. 1970 Dec 18;24(3):485-93.

113. Robinson TE, Kolb B. Structural plasticity associated with exposure to drugs of abuse. Neuropharmacology. 2004;47 Suppl 1:33-46.

114. lancu R, Mohapel P, Brundin P, Paul G. Behavioral characterization of a unilateral 6-OHDA-lesion model of Parkinson's disease in mice. Behav Brain Res. 2005 Jul 1;162(1):1-10.

115. Glajch KE, Fleming SM, Surmeier DJ, Osten P. Sensorimotor assessment of the unilateral 6-hydroxydopamine mouse model of Parkinson's disease. Behav Brain Res. 2012 May 1;230(2):309-16.

116. Heuer A, Smith GA, Lelos MJ, Lane EL, Dunnett SB. Unilateral nigrostriatal 6hydroxydopamine lesions in mice I: motor impairments identify extent of dopamine depletion at three different lesion sites. Behav Brain Res. 2012 Mar 1;228(1):30-43. 
117. Na SJ, DiLella AG, Lis EV, Jones K, Levine DM, Stone DJ, et al. Molecular profiling of a 6-hydroxydopamine model of Parkinson's disease. Neurochem Res. 2010 May;35(5):761-72.

118. Chhor V, Le Charpentier T, Lebon S, Ore MV, Celador IL, Josserand J, et al. Characterization of phenotype markers and neuronotoxic potential of polarised primary microglia in vitro. Brain Behav Immun. 2013 Aug;32:70-85.

119. Kroner A, Greenhalgh AD, Zarruk JG, Passos Dos Santos R, Gaestel M, David $S$. TNF and increased intracellular iron alter macrophage polarization to a detrimental M1 phenotype in the injured spinal cord. Neuron. 2014 Sep 3;83(5):1098-116.

120. Vasilevko V, Ghochikyan A, Holterman MJ, Agadjanyan MG. CD80 (B7-1) and CD86 (B7-2) are functionally equivalent in the initiation and maintenance of CD4+ Tcell proliferation after activation with suboptimal doses of PHA. DNA Cell Biol. 2002 Mar;21(3):137-49.

121. Colton CA. Heterogeneity of microglial activation in the innate immune response in the brain. J Neuroimmune Pharmacol. 2009 Dec;4(4):399-418.

122. Choi SH, Aid S, Kim HW, Jackson SH, Bosetti F. Inhibition of NADPH oxidase promotes alternative and anti-inflammatory microglial activation during neuroinflammation. J Neurochem. 2012 Jan;120(2):292-301.

123. Sanders LH, Timothy Greenamyre J. Oxidative damage to macromolecules in human Parkinson disease and the rotenone model. Free Radic Biol Med. 2013 Sep;62:111-20.

124. Hegde ML, Gupta VB, Anitha M, Harikrishna T, Shankar SK, Muthane U, et al. Studies on genomic DNA topology and stability in brain regions of Parkinson's disease. Arch Biochem Biophys. 2006 May 15;449(1-2):143-56.

125. Sanders LH, McCoy J, Hu X, Mastroberardino PG, Dickinson BC, Chang CJ, et al. Mitochondrial DNA damage: molecular marker of vulnerable nigral neurons in Parkinson's disease. Neurobiol Dis. 2014 Oct;70:214-23.

126. Erblich B, Zhu L, Etgen AM, Dobrenis K, Pollard JW. Absence of colony stimulation factor-1 receptor results in loss of microglia, disrupted brain development and olfactory deficits. PLoS One. 2011;6(10):e26317.

127. Wang Y, Szretter KJ, Vermi W, Gilfillan S, Rossini C, Cella M, et al. IL-34 is a tissue-restricted ligand of CSF1R required for the development of Langerhans cells and microglia. Nat Immunol. 2012 Jun 24;13(8):753-60.

128. Lin $H$, Lee $E$, Hestir K, Leo C, Huang M, Bosch E, et al. Discovery of a cytokine and its receptor by functional screening of the extracellular proteome. Science. 2008 May 09;320(5877):807-11.

129. Elmore MR, Najafi AR, Koike MA, Dagher NN, Spangenberg EE, Rice RA, et al. Colony-stimulating factor 1 receptor signaling is necessary for microglia viability, 
unmasking a microglia progenitor cell in the adult brain. Neuron. $2014 \mathrm{Apr}$ $16 ; 82(2): 380-97$.

130. Dagher NN, Najafi AR, Kayala KM, Elmore MR, White TE, Medeiros R, et al. Colony-stimulating factor 1 receptor inhibition prevents microglial plaque association and improves cognition in 3xTg-AD mice. J Neuroinflammation. 2015 Aug 01;12:139.

131. Spangenberg EE, Lee RJ, Najafi AR, Rice RA, Elmore MR, Blurton-Jones $M$, et al. Eliminating microglia in Alzheimer's mice prevents neuronal loss without modulating amyloid-beta pathology. Brain. 2016 Apr;139(Pt 4):1265-81.

132. He Y, Appel S, Le W. Minocycline inhibits microglial activation and protects nigral cells after 6-hydroxydopamine injection into mouse striatum. Brain Res. 2001 Aug 03;909(1-2):187-93.

133. Sriram K, Miller DB, O'Callaghan JP. Minocycline attenuates microglial activation but fails to mitigate striatal dopaminergic neurotoxicity: role of tumor necrosis factor-alpha. J Neurochem. 2006 Feb;96(3):706-18.

134. Domercq M, Matute C. Neuroprotection by tetracyclines. Trends Pharmacol Sci. 2004 Dec;25(12):609-12.

135. Moller T, Bard F, Bhattacharya A, Biber K, Campbell B, Dale E, et al. Critical data-based re-evaluation of minocycline as a putative specific microglia inhibitor. Glia. 2016 Oct;64(10):1788-94.

136. Scheuer T, Brockmoller V, Blanco Knowlton M, Weitkamp JH, Ruhwedel T, Mueller S, et al. Oligodendroglial maldevelopment in the cerebellum after postnatal hyperoxia and its prevention by minocycline. Glia. 2015 Oct;63(10):1825-39.

137. Keller AF, Gravel M, Kriz J. Treatment with minocycline after disease onset alters astrocyte reactivity and increases microgliosis in SOD1 mutant mice. Exp Neurol. 2010 Mar;228(1):69-79.

138. Rice RA, Pham J, Lee RJ, Najafi AR, West BL, Green KN. Microglial repopulation resolves inflammation and promotes brain recovery after injury. Glia. 2017 Mar 02.

139. Molina-Luna K, Pekanovic A, Rohrich S, Hertler B, Schubring-Giese M, RioultPedotti MS, et al. Dopamine in motor cortex is necessary for skill learning and synaptic plasticity. PLoS One. 2009 Sep 17;4(9):e7082.

140. Mann A, Chesselet M. Chapter 8 - Techniques for Motor Assessment in Rodents. Moviment Disorders (Second Edition). 2014:139-57.

141. Matsuura K, Kabuto $\mathrm{H}$, Makino $\mathrm{H}$, Ogawa $\mathrm{N}$. Pole test is a useful method for evaluating the mouse movement disorder caused by striatal dopamine depletion. $J$ Neurosci Methods. 1997 Apr 25;73(1):45-8. 
142. Neely KM, Green KN, LaFerla FM. Presenilin is necessary for efficient proteolysis through the autophagy-lysosome system in a gamma-secretaseindependent manner. J Neurosci. 2011 Feb 23;31(8):2781-91.

143. Elmore MR, Lee RJ, West BL, Green KN. Characterizing newly repopulated microglia in the adult mouse: impacts on animal behavior, cell morphology, and neuroinflammation. PloS one. 2015;10(4):e0122912.

144. Rabinowitz SS, Gordon S. Macrosialin, a macrophage-restricted membrane sialoprotein differentially glycosylated in response to inflammatory stimuli. J Exp Med. 1991 Oct 1;174(4):827-36.

145. Butovsky O, Jedrychowski MP, Moore CS, Cialic R, Lanser AJ, Gabriely G, et al. Identification of a unique TGF-beta-dependent molecular and functional signature in microglia. Nat Neurosci. 2014 Jan;17(1):131-43.

146. Michetti F, D'Ambrosi N, Toesca A, Puglisi MA, Serrano A, Marchese E, et al. The S100B story: from biomarker to active factor in neural injury. J Neurochem. 2011 Aug 24.

147. Kalogeropulou AF, Zhao J, Bolliger MF, Memou A, Narasimha S, Molitor TP, et al. P62/SQSTM1 is a novel leucine-rich repeat kinase 2 (LRRK2) substrate that enhances neuronal toxicity. Biochem J. 2018 Apr 9;475(7):1271-93.

148. Fleming SM, Salcedo J, Fernagut PO, Rockenstein E, Masliah E, Levine MS, et al. Early and progressive sensorimotor anomalies in mice overexpressing wild-type human alpha-synuclein. J Neurosci. 2004 Oct 20;24(42):9434-40.

149. Yang X, Ren H, Wood K, Li M, Qiu S, Shi FD, et al. Depletion of microglia augments the dopaminergic neurotoxicity of MPTP. FASEB J. 2018 Jun;32(6):333645.

150. Monville C, Torres EM, Dunnett SB. Comparison of incremental and accelerating protocols of the rotarod test for the assessment of motor deficits in the 6-OHDA model. J Neurosci Methods. 2006 Dec 15;158(2):219-23.

151. Tillerson JL, Caudle WM, Reveron ME, Miller GW. Detection of behavioral impairments correlated to neurochemical deficits in mice treated with moderate doses of 1-methyl-4-phenyl-1,2,3,6-tetrahydropyridine. Exp Neurol. 2002 Nov;178(1):80-90.

152. Sanchez-Guajardo V, Febbraro F, Kirik D, Romero-Ramos M. Microglia acquire distinct activation profiles depending on the degree of alpha-synuclein neuropathology in a rAAV based model of Parkinson's disease. PLoS One. 2010 Jan 20;5(1):e8784.

153. Rappold PM, Tieu K. Astrocytes and therapeutics for Parkinson's disease. Neurotherapeutics. 2010 Oct;7(4):413-23. 
154. Niranjan R. The role of inflammatory and oxidative stress mechanisms in the pathogenesis of Parkinson's disease: focus on astrocytes. Mol Neurobiol. 2014 Feb;49(1):28-38.

155. Morales I, Sanchez A, Rodriguez-Sabate C, Rodriguez M. Striatal astrocytes engulf dopaminergic debris in Parkinson's disease: A study in an animal model. PLoS One. 2017;12(10):e0185989.

156. Pascual O, Ben Achour S, Rostaing P, Triller A, Bessis A. Microglia activation triggers astrocyte-mediated modulation of excitatory neurotransmission. Proc Natl Acad Sci U S A. 2012 Jan 24;109(4):E197-205.

157. Schanen NC. Molecular approaches to the Rett syndrome gene. J Child Neurol. 1999 Dec;14(12):806-14.

158. Chahrour M, Zoghbi HY. The story of Rett syndrome: from clinic to neurobiology. Neuron. 2007 Nov 8;56(3):422-37.

159. Gantz SC, Ford CP, Neve KA, Williams JT. Loss of Mecp2 in substantia nigra dopamine neurons compromises the nigrostriatal pathway. J Neurosci. 2011 Aug 31;31(35):12629-37.

160. Samaco RC, Mandel-Brehm C, Chao HT, Ward CS, Fyffe-Maricich SL, Ren J, et al. Loss of MeCP2 in aminergic neurons causes cell-autonomous defects in neurotransmitter synthesis and specific behavioral abnormalities. Proc Natl Acad Sci U S A. 2009 Dec 22;106(51):21966-71.

161. Xie T, Zhang J, Yuan X, Yang J, Ding W, Huang X, et al. Is X-linked methylCpG binding protein 2 a new target for the treatment of Parkinson's disease. Neural Regen Res. 2013 Jul 25;8(21):1948-57.

162. Derecki NC, Cronk JC, Lu Z, Xu E, Abbott SB, Guyenet PG, et al. Wild-type microglia arrest pathology in a mouse model of Rett syndrome. Nature. 2012 Mar 18;484(7392):105-9. 